Marjaana Jauhola

Scraps of Hope

in Banda Aceh

Gendered Urban Politics

in the Aceh Peace Process 


\section{Scraps of Hope in Banda Aceh}

\section{Gendered Urban Politics in the Aceh Peace Process}

Marjaana Jauhola

Pro et Contra 1 
Published by

Helsinki University Press

www.hup.fi

(C) Marjaana Jauhola 2020

First published in 2020

Cover design by Ville Karppanen

Cover photo: Pietro Scozzari / Alamy

Video credits:

Production: Scraps of Hope / Marjaana Jauhola

Main camera, script, edit: Heartwaves Design / Seija Hirstiö

Research, script, camera 2: Marjaana Jauhola

Interviews: Marjaana Jauhola, Zubaidah Djohar

Transcripts and translations: Evi Susianti, Mifta Sugesti

Print and digital versions typeset by Siliconchips Services Ltd.

FINNISH POLITICAL SCIENCE

ASSOCIATION

Pro et Contra. Books from the Finnish Political Science Association

ISSN (Print): 2736-8513

ISSN (Online): 2736-9129

ISBN (Paperback): 978-952-369-016-5

ISBN (PDF): 978-952-369-017-2

ISBN (EPUB): 978-952-369-018-9

ISBN (Mobi): 978-952-369-019-6

https://doi.org/10.33134/pro-et-contra-1

This work is licensed under the Creative Commons Attribution 4.0 International License (unless stated otherwise within the content of the work). To view a copy of this

license, visit http://creativecommons.org/licenses/by/4.0/ or send a letter to Creative Commons, 444 Castro Street, Suite 900, Mountain View, California, 94041, USA. This license allows for copying any part of the work for personal and commercial use, providing author attribution is clearly stated.

The full text of this book has been peer reviewed to ensure high academic standards.

For full review policies, see http://www.hup.fi/

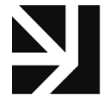

VERTAISARVIOITU

KOLLEGIALT GRANSKAD

PEER-REVIEWED

www.tsv.fi/tunnus

Suggested citation:

Jauhola, Marjaana. 2020. Scraps of Hope in Banda Aceh: Gendered Urban Politics in the Aceh Peace Process. Helsinki: Helsinki University Press. https://doi.org/10.33134

/pro-et-contra-1.

To read the free, open access version of this book online, visit https://doi.org/10.33134/pro-et-contra-1 or scan this QR code with your mobile device: 


\section{Contents}

List of Illustrations vii

List of Videos ix

Acknowledgements xi

Introduction: No More - Re-Centring the Subalterns

of the Aceh Peace Process 1

De-Centring the Masculinist Peace Mediation 5

MoU poetry $\quad 5$

Outline of the Argument 12

Chapter 1: Stumbling Scholarship: Reversing Research Praxis of Everyday Subjectivities 17

1.1. Researched Subjects and Postcolonial Paranoias 17

1.2. On Everyday Subjectivities: Feminism, Islam, Agency and Freedom 20

1.3. Methods for Decolonisation / Reversal of Research Praxis 28

1.4. From Street Ethnography to Film Production, and Visual Representations $\quad 32$

1.4.1. Multi-Sited Ethnography (2012-2016) 32

1.4.2. On Documentary Video Production 36

1.4.3. Teasing Out a Coherent Story 38

1.5. Beyond Fables and Peace Brands 43

Chapter 2: Kota Madani (Civilised City) and the Struggle to Define Ideal Womanhood 45

2.1. City in Transition and the Rise of Sharia Populism 45

2.2. Governance of Gender and Sexual Politics:

Colonial (Dis)Continuities? 48

2.3. Kota Madani - Towards a 'Civilised Islamic City'

2.4. Bunda’s Advice: Paradise Awaits 66

Nasihat bunda-Mother's advice $\quad 67$

2.5. Guidance towards Ideal Womanhood through State Structures 73 
2.6. Contestation of the Public Sphere and Islamic Women's Respectability 76

2.7. Paradise Awaits, for Whom?

Chapter 3: 'Because You Are a Woman': Resisting a Single Story

3.1. Smile that Hides Sorrow?

3.2. Stranger in Her Own Village

3.3. Solving Problems Like a Man

3.4. Cursed by the Second Wife

3.5. Grandmother Really Understood Me 100

3.6. What to Do If No Children Are Mine? 103

3.7. Smile as a Self-Care?

Chapter 4: Subjugated Post-Conflict Masculinities: From Premanisme to Sufism

4.1. The Many Faces of Masculinities

4.2. The Long Journey from 1976 to 2016

4.3. Premanisme and Conflict Presence in the Post-Conflict City

4.4. Subjugated Non-Violent Masculinities - Oral Transmission of 'Kitab Mujarabat'

4.5. Ilmu Bodoh - Healing as an Alternative Political Economy?

Chapter 5: Chaotic Pavements: Punk/Metal Scene Keeping the Traumas of the City Open

5.1. Bastard Illiza and Punks' Politics of Repression in Banda Aceh

5.2. Our Wounds: Keeping the Tsunami Trauma Open

5.3. Rhizomatic Homes across the Indonesian Archipelago

5.4. Justice - Studying Up the Rule of Law

5.4.1. Chronology of the Rex Incident

5.4.3. Written by Yudi Bolong at Tsunami Museum Banda Aceh, 26 May 2014

5.4.4. Marjaana's Reflection on Gendered Everydays of Ethnography

5.5. Chronic - Changing Dimensions through Metal

5.6. Difference Is Not a War

Chapter 6: Queer Community and Care: Being and Belonging in the Verandah of Mecca

6.1. 'Queering Peace' in Aceh? Reflecting on Theory and Methodology 161

6.2. Queer Aceh 
6.3. The LGBTI Activist City 171

6.4. Becoming Tomboi and Transman in Aceh 173

6.5. Poetic Expressions of Love, Intimacy and Care 176

6.6. Knowledge as Violence: Strategy to 'Wipe Out' LGBTI from Aceh 180

$\begin{array}{ll}\text { 6.7. Precarious Queer Virtuality } & 184\end{array}$

6.8. Negotiating Dignity and Safety with Local and Global Human Rights Defenders 189

6.9. From Queering to Dig, Dag, Dug - Feeling of a Heartbeat 190

Chapter 7: The Political Economy of the PET Bottle 193

7.1. In Search of Piety through Bottled Water 193

$\begin{array}{ll}\text { 7.2. History and Context } & 197\end{array}$

7.3. Bottle Recycling Centre 201

7.4. Street Economics: From an Internally Conflict-Displaced Preman Economy to Social Rafting 210

7.5. Commodification of Water in a Middle-Class Family 212

7.6. From Shadows of Political Economy to Seeking Just Futures 214

Conclusions: Centring Ilmu Bodoh Foolish Knowledge,

Changing the Way in Which Gendered Peace Is Conceptualised? 217

$\begin{array}{ll}\text { Glossary } & 225\end{array}$

$\begin{array}{ll}\text { Notes } & 231\end{array}$

$\begin{array}{ll}\text { References } & 243\end{array}$

$\begin{array}{ll}\text { A Note on the Sources of the Chapters } & 271\end{array}$

$\begin{array}{ll}\text { Index } & 273\end{array}$ 



\section{List of Illustrations}

Image 1: Helsinki MoU handshake used in the peace mediation white paper in 2010.

Image 2: Map of Banda Aceh. 33

Image 3: Film poster with Illiza. $\quad 68$

Image 4: Tupperware sales exhibition at Taman Sari. 75

Image 5: Hajj event - dance/karaoke. $\quad 76$

Image 6: HT's Women and Shariah Campaign phases. 79

Image 7: Illiza bastard. $\quad 130$

Image 8: Gig advertisement from 2014.

Image 9: Instagram post by Mayor Illiza in 2016.

Image 10: Suggested video effect for Coaching to be strong transman video. 186

Image 11: Plastic cup recycling in Banda Aceh. 194

Image 12: Implementation of Sharia Islam results in guidance, managing waste and ultimate blessing. 



\section{List of Videos}

Video 1: Scraps of Hope Aceh teaser (02:23). 2

Video 2: Poetic resistance I: whose peace is this? (05:07).

Video 3: MoU Helsinki: reclaiming back history (16:52). 12

Video 4: Sharia and visions for peace: blueprint for just and equal Islamic law (10:29). 53

Video 5: Poetic resistance II: because you are a woman (03:20). $\quad 88$

Video 6: Smile that hides sorrow (08:19). 90

Video 7: Solving nikah siri - unregistered marriage (09:46). 93

Video 8: A good mother (07:37). 100

Video 9: From ex-combatant to Sufi healer 1-3 (08:21). 116

Video 10: From ex-combatant to Sufi healer 1-3 (05:55). 116

Video 11: From ex-combatant to Sufi healer 1-3 (05:44). 117

Video 12: Totaliter: penjara pemikiran/prison of thoughts (02:12). 151

Video 13: Coaching to be strong transman (05:59). 185

Video 14: Don't be angry (03:19). 206

Video 15: Dreamcatcher (06:24). 213 



\section{Acknowledgements}

This book and the accompanied video documentaries would have not been possible without the support of a number of people over the past eight years, some going way beyond that, all the way to early 2000s at the Peace Station in Helsinki and dialogue with Acehnese human rights defenders.

First of all, I want to thank all those Acehnese who allowed the project team and me to enter your homes and lives - I have a deep gratitude of having gained insights that led research towards appreciating Ilmu Bodoh, subaltern theorising on peace. On behalf of all of us who have formed the Scraps of Hope team during these years, we sincerely hope that we can live up to your expectations of this journey. Any representational biases and mistakes are solely ours.

I also want to thank all the Acehnese counterpart organisations and their staff members, directors, researchers, lecturers and, most importantly, administrative staff members facilitating the paper bureaucracy related to foreign researcher visits in Aceh between the years 2012 and 2018. These institutions are the International Centre for Aceh and Indian Ocean Studies (ICAIOS), the University of Malikussaleh (UNIMAL) and the Islamic State University Ar-Raniry (UIN). My special gratitude goes to the staff of the Embassy of Republic of Indonesia in Helsinki and in particular the Ambassador of Indonesia in Finland, H. E. Wiwiek Setyawati Firman, for facilitating the filming permissions for 2015, and taking part in the University of Helsinki Think Corner Talk - Poetry - Dance ZUBAIDAH DJOHAR: BUILDING A BOAT IN A PARADISE - FEMINIST LITERATURE THAT RESISTS FORGETTING 
evening in November 2017. The Scraps of Hope team, daring to dream of a media-embedded, peer-reviewed monograph already in 2015, we truly were ahead of the times! Thank you Seija Hirstiö, Ariyuki Suzuki, Päivi Nikkilä, and Riitta Koikkalainen and Jukka Turunen for being part of Scraps of Hope! My gratitude for all the hard work by Rahmat in Aceh for essential logistics and additional camerawork in recordings in December 2015. Evi Sugianty (ICAIOS) and Mifta Sugesti - your professionalism in going through interview and video recordings, providing transcripts, translations and detailed comments on the draft videos, has provided deepened perspectives to ethnographic moments that could otherwise go unnoticed.

My sincere thanks to poet, trainer, researcher and friend Ibed, Zubaidah Djohar and a colleague at UNIMAL campus Nanda Amalia, and all her colleagues who invited me to their classes in 2012. A special thank you to the Creative Minority student group for initiating the creative writing workshops leading to Zubaidah Djohar's edited book Dalam Keriput Yang Tak Usang: Suara Pemuda Dan Jalan Panjang Perdamaian Aceh and similarly, all the voluntary effort that went into writing, editing and publishing the book Bisu yang Bersuara, collection of writings of female survivors of violence in the midst of peace in Aceh after the initial joint writing workshop organized in August 2018. Similarly, the whole of the Generasi-Generasi Damai - Peace Generations video team in both Aceh led by Davi Mashury and recordings completed by Susanna Hast in Helsinki. My gratitude also to the Vantaa Art Museum (Artsi) staff, Let's Speak Peace exhibition curator Jani Leinonen, and President Tarja Halonen, artist Sasha Huber and journalist Abdirahim 'Husu' Hussein for your valuable contribution to conceptualising peace.

$<3$ to all those wonderful people who made the Helsinki GenderPeaceSecurity (GPS) research collective event Utopias of Peace in October 2017 possible: Carmen Baltzar, the Young Muslims and Resilience project, Rita Manchanda, Minna Seikkula, Susanna Hast, Judy Pasimio, Pieta Hyvärinen, Jasmina Amzil, Sophia Wekesa, Ruskeat Tytöt and student-led Feminist Collective. Likewise, the participants and organisers of the Peace Agreements +10 years - Women and Post-Conflict Realities - event that also made possible the Smolna talks with Professor Eka Srimulyani and Donna Swita. Thank you also to Associate Professor Mulki al-Sharmani at the University of Helsinki, and General Secretary Hannele Varsa at the Gender Equality Council for having facilited this rare visit from Aceh. My appreciation for the solidarities built at the event Black Women's Voices and the Rise of Hate in Tiedekulma in January 2019. Thank you Silvana Bahia, Mariyam Abdulkarim, Bianca Benini, Monica Gathuo and Leonardo Custódio.

Reversing the ethnographic research praxis has also included exposing the yet-to-be written ethnography for discussion at more than 20 screening events throughout the years 2016 to 2019, including at the Tikkurila public library the municipality of Vantaa's pop-up space making the lesser-known town of the 
Aceh Peace Process connected to the peace-building effort and at Kilteri junior high school. And, of course, huge thanks go to students at the University of Helsinki, the University of Lausanne, Saint Louis University/Madrid Campus and the South Asian University in New Delhi in invited classes and seminars of International Relations, Gender and Development Studies, and Theology, where the ideas and videos have been discussed and debated between 2015 and 2019. Thanking you all for engaging with the research with your valuable and insightful perspectives! Thank you to Rahel Kuntz, Simona Rentea, Soumita Basu and Shweta Singh, Anja Nygren and Mulki Al-Sharmani and Katja Grekula for the invitations.

Thank you to Professor Eka Srimulyani (UIN Ar-Raniry) and emerging scholar Era Maida for the hundreds of hours' worth of video conference calls to form a 'female conspiracy' and peer support network while working on other scholarly contributions. I also want to thank colleagues at the University of Helsinki in the Faculty of Social Sciences in Development Studies, especially Henni Alava, Minna Hakkarainen, Elina Oinas and Henri Onodera, and the Faculty of Arts in Gender Studies - especially Johanna Kantola, Nina Järviö and AinoMaija Hiltunen; the feminist International Relations community in Finland, especially Saara Särmä, Tiina Vaittinen, Susanna Hast, Tiina Seppälä, Leena Vastapuu and Minna Lyytikäinen; and the wider networks of queer, postcolonial and anti-racist feminist gatherings around ISA and BISA, and the Feminist Peace Research Network. This research also led to pioneering course Vismeth (visual methods in social sciences/visual anthropology) developed collectively with my other visual-oriented and talented colleagues at the Faculty of Social Sciences: Kazu Ahmed, Andrea Butcher, Henri Onodera and Salla Sariola. Special thanks to director and teacher Jouko Aaltonen for all the coaching and support along the way of designing and running the course. Huge thank you for nurturing my writing and final touches to the excitingly new book format goes to copy editors Marie-Louise Karttunen and Sophie Rosinke, Pro et Contra book series Taru Haapala and Anna Kronlund, and Anna-Mari Vesterinen and Heta Björklund from Helsinki University Press.

Warmest thanks go to my dear friends and colleagues Leena Avonius and Emilia Palonen for the needed colleagual smoke saunas, drinks and dinners. Last but not least, I thank my families: in Finland, for believing in a first-generation scholar; and my second family in Zarpara, Kachchh in Gujarat for caring during the challenging COVID-19 lockdown months spent in 2020 at the farm, learning quilting and preparing the book manuscript for publishing. આભાર.

This research, the documentary video production and writing up the book has been made possible with the following research and video documentary funding: University of Helsinki Post-Doctoral Researcher funding (20132014); Finnish Cultural Foundation funding (2015); and Academy of Finland Fellowship (2015-2020). 



\title{
Introduction
}

\section{No More - Re-Centring the Subalterns of the Aceh Peace Process}

\author{
If never once known, \\ How to write out one's history? \\ How to delve into the past, \\ So thickly shrouded in anonymity? \\ How to clutch more wisps of threads \\ of family lore and tales \\ of heroic deeds and singular traits \\ in salty Ulee Lheue? \\ Write out your narrative, now \\ trace it, trace it. \\ Return to your roots \\ Quickly embrace it, \\ make it yours, make it. \\ Bite into its texture \\ taste it, taste it \\ before it drowns \\ forever under inscrutable tsunami
}

'No more' (Yatim 2005, 3)

This book is inspired by Acehnese scholar Eka Srimulyani's appeal to bring 'the sub-altern narrative and stories to the fore so the marginalized groups and perspectives can be brought to the discourse and common knowledge of the people' and, in order to do so, it requires revisiting 'the notion of agency and 
explor[ing] the different agencies that were the sub-altern model or pattern to the fore by exploring the "herstories" and personal but political narratives' (Srimulyani 2017, 92-93).

In what ways does the focus on the everyday of peace-making, or the outcast, the invisible, challenge the narrative and ideals of a peace as successful, or a city as 'built back better'? What alternative futures can those stories point towards? How does ethnographic and film documentarist storytelling provide ways for subaltern peace dialogue? How should we understand, retrospectively, what peace-making in the city entails? What messages are sent back to those whose handshakes made Helsinki, and the peace process globally celebrated as a sustained peace and 'success story'? This book demonstrates that the success narrative of the peace mediation goes hand in hand with its aftermaths and the political, social, economic and experienced shades of the celebration, which Rahul Rao has recently called the 'postcolonial strategy of countering orientalism by demonstrating the mutual constitution of core and periphery' (Rao 2020, 21).

Following the lives of people through their everyday experiences in the provincial capital of Banda Aceh, this book offers insights into the relations of power and structures of violence that are embedded in the peace: layered exiles and displacement; narratives of violence and grief; struggles over gendered expectations of being good and respectable women and men; the hierarchical political economy of post-conflict and tsunami reconstruction; and multiple

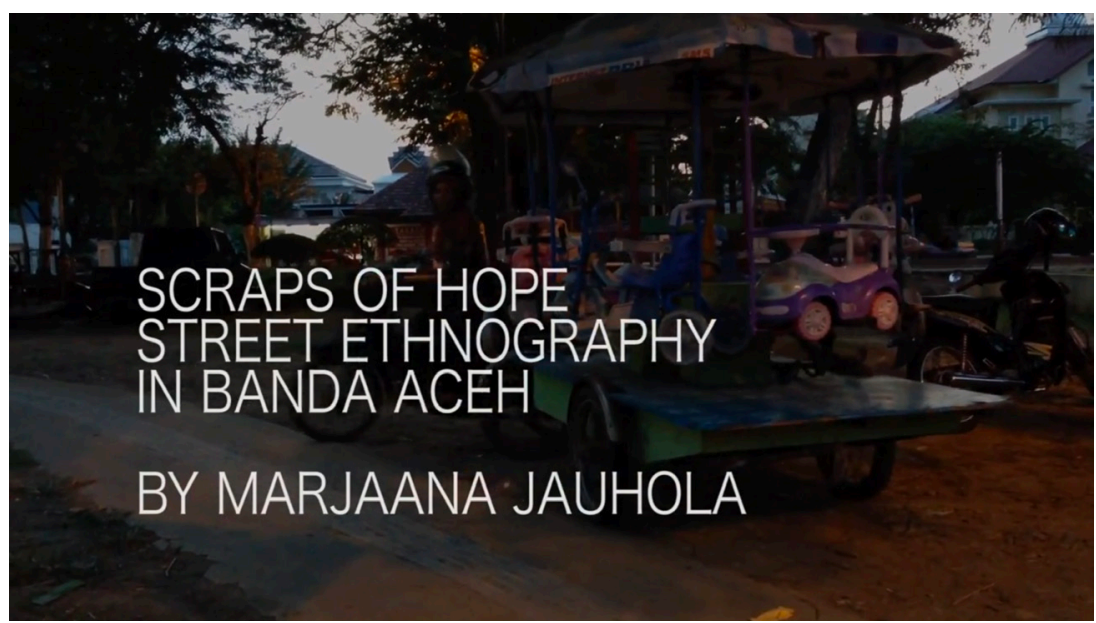

Video 1: Scraps of Hope Aceh teaser (02:23).

Source: Scraps of Hope.

To watch this video, scan the QR code with your mobile device or visit DOI: https://doi.org/10.33134/pro-et-contra-1-video-1

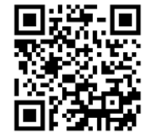


ways of arranging lives and remembrance, cherishing loved ones and forming caring and loving relationships outside the normative notions of nuclear family and home. This book aims to cover a number of scholarly fields and study areas: in particular, a crossroad of urban studies - the emerging field of everyday peace ethnographies, but also everyday Islamic studies, and that of the feminist post-conflict and post-disaster scholarship.

This book joins calls to decolonise post-disaster theorising and analysis (D'Costa 2006; Jones 2009; Bhambra 2014; Shilliam 2015; Vitalis 2015). It engages with such recent works as Meera Sabaratnam's (2017) analysis of international interventions, and the Eurocentrism of critical debates on them. According to Sabaratnam, such debate is

... haunted by five particular avatars of Eurocentrism ... a bypassing of target subjects in empirical research; the analytic bypassing of subjects in frameworks of governmentality; an ontology of cultural Otherness distinguishing the 'liberal' from the 'local'; the analytic constraints of 'everyday' approaches; and nostalgia for the liberal social contract, the liberal subject and European social democracy.

Sabaratnam 2017, 23

Instead of assuming that such demands are new, the process of preparing the research (see in detail Chapter 1) has meant rereading classics, such as Chandra Talpade Mohanty's famous article 'Under Western eyes' and the revisited essay from 2003, where Mohanty suggests that 'cross-cultural feminist scholarship must be attentive to micropolitics of context, subjectivity, and struggle, as well as to the micropolitics of global economic and political systems and processes' (Mohanty 2003, 501), and that any seriously taken research should always be grounded, particularised analysis linked with global, economic and political frameworks (ibid.) and thus continue resisting the universal understanding of gender, or women, and 'monolithic notion of sexual difference' (Mohanty 1984, 344). Some 35 years later, Braithwaite and D'Costa (2018) have suggested that failures of peace-building can be explained by neglect, or lack of attention to the interscalarity, namely, how violence and power relations cascade and how contestation of power 'that may be located at different scales and involved in complex, tactical, multi-scalar alliances explain the uneven outcomes of international interventions' (ibid., 21). Thus, understanding the politics of peace requires 'zooming in and out on many scales and to the interscalar' and an 'adjustable lens to be attuned to see and hear the local and a lens that can be widened to national, regional, global or other levels' (ibid., 21).

Along the lines of interscalarity and cascading effects, in 2013, in an ethnographic study of gender aid and the gender-mainstreaming politics of posttsunami reconstruction in Aceh (Jauhola 2013), I argued that in order to locate feminist potential in post-disaster and post-conflict settings, the forms taken by feminist politics in the context of aftermath reconstruction require rethinking. 
Despite the fact that feminist disaster studies have drawn attention to postdisaster politics and power for decades, theory-generation concerned with crises is dominated by big data, a digital and technological focus (Chandler 2015), blatant gender blindness (Bradshaw 2013), and the logics of a Western, universalising system of knowledge/power relations, proposed ontologies and epistemologies (Harding 2008; Noble 2017). Well-known Indonesian author and public intellectual Pramoyedia Toer strew the politics of decolonisation, and understood post-colonial Indonesia as a nation emerging as 'a tapestry woven from countless threads, representing classes, ethnic and religious groups in their struggle for justice' (Setiadi 2014, v). Following Denise Noble, this critique 'produce[s] the ethical and political imperative of decolonizing and feminizing freedom' (ibid.) and addresses the academic colonialism of 'dispossession, occlusion, erasure, and violence' (West 2016). How this translates into theorising and conducting ethnography on feminism, Islam, agency and freedom will be discussed in detail in Chapter 1.

This book returns to the city of Banda Aceh for the period of 2012-2016, when the 'tsunami of aid' - thousands of aid experts, their offices, their cars and employment opportunities (both for educated and for 'unskilled') - had decreased, when the crisis of global economic recession was impacting both urban and rural Acehnese lives, and when the politicisation of post-conflict dynamics was intensifying as contested articulations of peace-building and 'building Aceh back better' were being laid out. The temporal and analytical focus of this book lies on this 'Phase Two' of reconstruction that was no longer reliant on tsunami aid, but, rather, was drawing from government budgets, foreign investments and longer-term development aid injections, in which newly emerging (transnational) social movements and events, encounters and retold stories of the Acehnese heritage are rife. I revisit, in other words, precisely those ideological, financial, material and affective sites of the city that I suggested needed highlighting in 2013. I approach attempts to rebuild Banda Aceh through slogans such as 'building back better' and 'civilised city' (kota madani) ${ }^{1}$ as social practices that function as sites of struggle over legitimate political, economic and social subjectivities - increasingly framed as representative of Islamic populism and a growing middle class (Hadiz 2016). Understood in this way, the city is re-forming itself through myriad and mundane material encounters: fluid and pulsating with life, rather than stable and unchanging. Analysis of the unfolding city and its politics thus focuses on the lived and embodied everyday lives of Banda Acehnese in a city that is actively reordering historical events and narratives of what it is (Rico 2016, 29). Here Rahul Rao's conceptualisation of place through temporality allows us to understand it as a temporal process constituted by transnational relations and flows that unfold over time' (Rao 2020, 34). Thus, 'Aceh' or its capital 'Banda Aceh' are not just geographical locations, but part of the imagination of 'the international' and contested transnational demands of their future direction, iterated through liberal peace-building efforts, movements of political Islam, and technocrats and developmentalist interventions. 
Conceptualising the city and the lived everyday in this way follows a number of feminist scholars who study lives that are written out of the history of wars and their aftermaths (D'Costa 2006; see also Jauhola 2016), and ignored in analyses of the effects of secular and post-secular state rebuilding. The approach is also indebted to research that examines these processes in other contexts: firstly, in connection with post-conflict, post-disaster and development restructuring; secondly, in terms of phenomena such as religious revivalism, globalisation and social change (Al-Ali et al. 2008; Fulu 2014); and, thirdly, in relation to social transformation, Islamic law and transnational political Islam, and their complex effects on gendered bodies (Mahmood 2012 [2005]; Fulu 2014; Afrianty 2015). These works are located in a number of academic disciplines and approaches, but what is common to all is the aim of understanding the effects of assemblages of global politics, modernity, political economy, gendered state-building and everyday Islam, ${ }^{2}$ and how such landscapes 'reflect and mask - often simultaneously - discourses of order, contests for hegemony, and techniques of power' (Salvatore and LeVine 2005, 1).

Deniz Kandiyoti (2009) has illustrated the centrality of gender relations to the debates on modernity, the state and its reforms in the Muslim world during the 19th and 20th centuries, and increasingly so in more recent global politics of Islamic resurgence, and war-on-terror policies (see Jauhola 2013 for discussion in the context of Aceh and Indonesia more broadly). The politics of gender - processes of appropriation, contestation and reinterpretation of positions on gender relations and women's rights by state, non-state and global actors - has gained new twists in different parts of the Muslim world when blueprints for state-building are combined with those of armed interventions, such as in Afghanistan and Iraq (Kandiyoti 2007a, 2007b; Al-Ali et al. 2008; Kandiyoti 2009; Chaudhary et al. 2011; Dahlman 2011), but also, as recent scholarship on Aceh points out, in the context of 'Islamisation' of reconstruction efforts post-natural disaster and armed conflict (Miller 2010; Grossmann 2013; Jauhola 2013; Afrianty 2015). Other scholars have focused on the ethnographies and lived experiences of war (Nordstrom 1997; Sylvester 2011, 2013; Wibben 2016), highlighting the importance of research methodologies in opening up possibilities for new forms of engaged feminist analysis; works such as those by Aihwa Ong $(2003,2009,2010)$ on gendered citizenship and everyday resistance through processes of being-made and self-making (Ong 2003, xvii, 8-9) inform the theoretical and methodological set up of this book.

\section{De-Centring the Masculinist Peace Mediation}

\section{MoU poetry}

The goi and the gam confirm their commitment to

a peaceful comprehensive, sustainable solution to

the conflict in Aceh with dignity for all.

The goi and the gam will confirm 


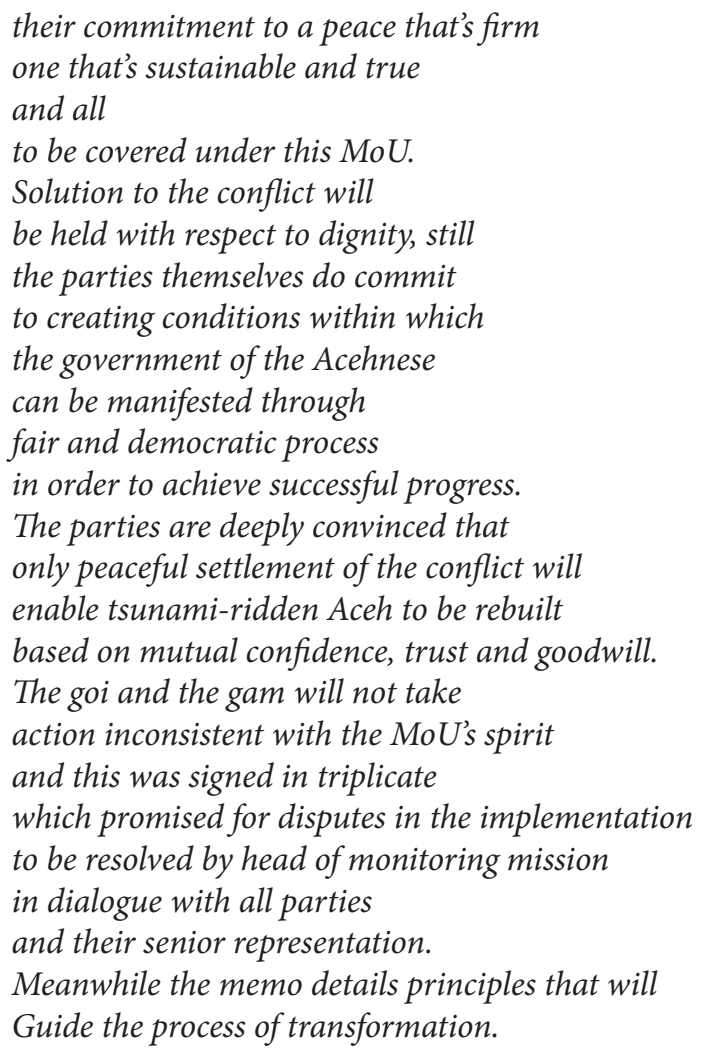

Over the past 15 years after the signing of the Memorandum of Understanding $(\mathrm{MoU})$, much has been said and analysed of the mediation process that led to the signing of the agreement, and the adoption of the Law on Governance of Aceh (LOGA) in 2006 (Aspinall 2008; May 2008; Miller 2008; Stange and Patock 2010; Tornquist 2011). Such research focuses on the key elements of the peace agreement, and the provisions of the LOGA: Disarmament, Demobilisation and Reintegration (DRR); the Aceh Monitoring Mission (AMM), which was mandated to monitor the implementation of the peace agreement; the formation of local political parties and elections held in the province; provisions for Sharia Law as a cornerstone for the legal framework and post-conflict legal reforms; a 70\% share of the natural resource revenues; and special autonomy funds granted for the province.

The Poetic resistance I: whose peace is this? video collage, based on the poem by Zubaidah Djohar, challenges the notions of completed and successful peace by highlighting the hidden and forgotten subaltern voices in Aceh that demand justice. This poem, an inspiration for this book's key research 


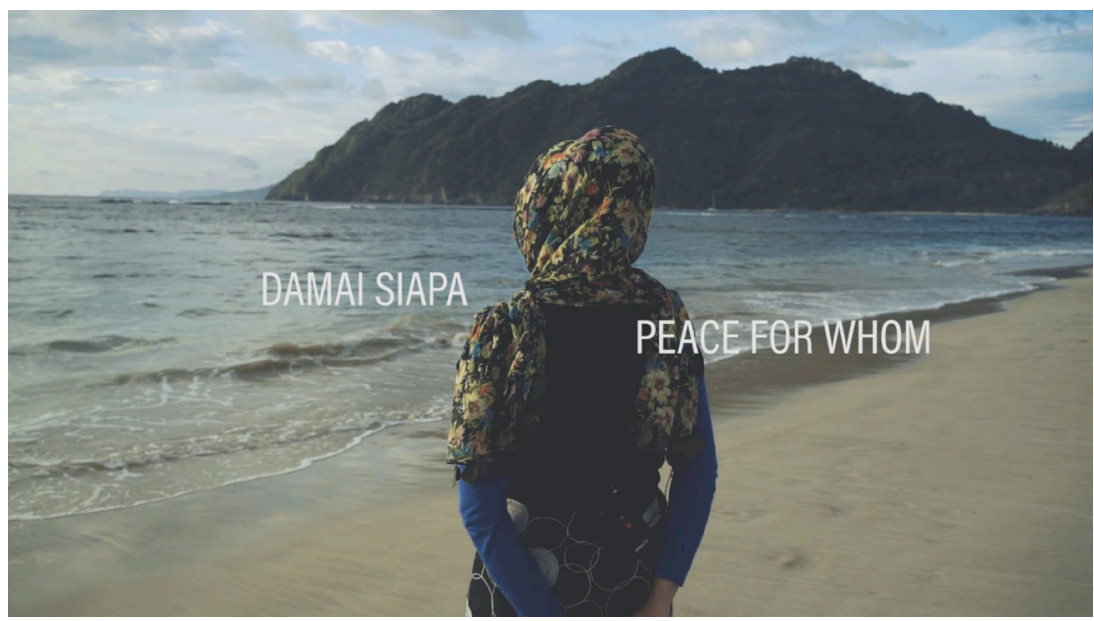

Video 2: Poetic resistance I: whose peace is this? (05:07).

Source: Scraps of Hope.

To watch this video, scan the QR code with your mobile device or visit DOI: https://doi.org/10.33134/pro-et-contra-1-video-2

questions, actively challenges normalised notions of success of the peace in Aceh, and encourages the seeking of alternative narratives.

Among the most critical voices of the success of the peace process, however, are those analysing the aftermaths of the process from feminist perspectives, focusing on gendered intersections of discrimination and inequalities, and political economy: they all agree in their analysis that the MoU represented a peace process that was a 'densely gendered, and problematic, conceptualisation of peace' (Lee-Koo 2012, 74). Furthermore, the peace process has led to a process of remilitarisation, which 'has centred on the reapplication of a set of militaristic ideas or ideology that is highly gendered - emphasising strong comradeship, the special, superior status of combatants, a hierarchical militarytype command structure and, critically, hegemonic militarised masculinities' (Abdulah 2018, 69-70). Furthermore, I have suggested that post-war backlash on gender-related forms aims to reproduce a nation through the symbolic value of women by emphasising how they embody cultural and national borders of a nation, and in need of protection. Simultaneously, strong taboos on female sexuality and sexual violence are (re)created. This patriarchal sexual ideology focuses simultaneously on female chastity and the 'fallen woman', and gains its power through discursive focus on decency, virtue, honour and national survival (Jauhola 2016, 333).

Much has been written of the renewal of predatory political economy and the emergence of new exclusionary local political elites (Aspinall 2009a), and of 
the growth of new religious institutions and power of religious leaders in social engineering through Shari'a law (Ichwan 2007, 2011; Feener 2013), and resistance through the turn to Islamic modernity and self-government, or care of the self, through piety and good morals (akhlak) (Kloos 2017; Samuels 2019). Yet, much less often does this analysis specifically analyse these dynamics, the aftermaths of the MoU, as gendered and sexualised, co-constituted through other intersecting inequalities, struggles over gender ideology and connectedness to the post-conflict political economy of Aceh (Lee-Koo 2012; Jauhola 2013; Abdulah 2018; Lee-Koo 2018).

In order to cast light on the gendered and sexualised politics of peace and its political economy, this book approaches the above-mentioned peace-mediation protagonists from afar, turning the focus to the subalterns, the abjected - or the ones 'written out of the history' (D'Costa 2006, 129) of the peace fable. Yet, being aware of the colonialist, racist and Eurocentric dangers in 'locating silence, powerlessness and oppression abroad' (Bertrand 2018, 291), this book also aims to address and identify the dangers of simplifying gendered experiences in Aceh (see, e.g., the critique in Mohanty 1984; Spivak 1988). Focusing primarily on non-elites, processes through which their lives are governed as a result of the negotiated peace $(\mathrm{MoU})$, and its realisation into laws, policies and practices, this book follows subaltern peace in the making. This subaltern in this book is located in Banda Aceh, the capital of the province of Aceh. However, as this book illustrates, everyday lives, contested techniques, processes and values iterated locally are connected in complex ways through the global (Ong and Collier 2005; Tsing 2005), including that of the MoU birthplace, Helsinki, the capital of Finland.

The city of Banda Aceh, located just 100 kilometres from the epicentre of the Indian Ocean earthquakes and tsunami of December 2004, was devastated during the catastrophe. It is estimated that around $60 \%$ to $80 \%$ of the infrastructure was destroyed, and over 78,000 of its 269,000 pre-tsunami residents were killed, although its population was augmented by more than 40,000 internally displaced persons in the aftermath. Yet, Banda Aceh is also the capital of a province that is rebuilding itself after three decades of armed conflict between the Indonesian army and the Free Aceh Movement (GAM). The Helsinki Peace Process, initiated just days before the tsunami, led to the signing of a Memorandum of Understanding between the two parties in August 2005, guaranteeing Aceh a position of self-government within the wider framework of the Republic of Indonesia. As part of the MoU, GAM agreed to demobilise its troops and decommission all arms, ammunition and explosives, while the Indonesian army pledged to withdraw all non-organic military and police forces from Aceh and stabilise the number and tasks of organic military and police forces in the province (May 2008).

By 2011, the population of Banda Aceh had returned to its pre-tsunami figure, with the biggest demographic increase indicating a simultaneous baby boom and in-migration of young adults (Mahdi 2014, 282-283). The physical 
rebuilding of the city over the past decade with reconstruction aid has gradually eradicated the visible scars of the tsunami, although numerous landmarks, such as boats which were washed far inland, have been preserved as memorials to commemorate the loss and destruction (for a detailed analysis of heritage narratives in Banda Aceh, see Rico 2016). Nowadays, visitors can join formal tours that visit the different 'tsunami sites' in the city: the Tsunami Museum, a fishing boat on the roof of a house, mass burial grounds, the tsunami education park, the 'Thanks to the World' monument and so on. At the same time, however, the city is going through a 'Phase 2' makeover that is constructing the city historically as an Islamic city - a city of the Sultanates, Serambi Mekkah (veranda of Mecca).

Banda Aceh was never a strong base for GAM during the conflict; rather, it was seen as an administrative hub, with its political and bureaucratic elite siding with the central government. However, many parts of the city centre were labelled 'black zones', no-go areas at night, due to gunfire and the threat of violence, and it was also a destination for IDPs (internally displaced persons) fleeing the province's high-conflict regions (Mahdi 2014, 276). Furthermore, despite the peace process, 11 years after the MoU was signed, both the military and police forces continue to have a strong presence in the city: the riverbanks of the centre accommodate the army's provincial and district commands, district police command, and civil service and Shari'a Police. Meanwhile, many ex-combatants have also migrated to Banda Aceh in search of employment and business opportunities, and as politicians (Aspinall 2009a; Myrttinen 2012). It is common to see police, military and ex-combatants patrolling the public parks and parking lots.

The city of Helsinki, located just 20 kilometres from the 16th-century manor house near Helsinki where the five rounds of the peace negotiation between the Government of Indonesia (GOI) and GAM were held in 2005, provided the stage, and offered its name for the signing ceremony of the negotiation result, a document known as the MoU or the Helsinki MoU. The ceremony is mostly known for its famous handshake at Smolna, government banquet hall, where the negotiating parties, the representative of the Government of Indonesia, Justice and Human Rights Minister Hamid Awaludin on the left, and head of the GAM delegation, Malik Mahmud, on the right, shake hands in front of the international press (Image 1). This symbolic gesture is overseen by the mediator, former Finnish President Martti Ahtisaari, and is witnessed by the representatives from the negotiation teams and Ahtisaari's mediation team. The image has since become a symbol of both a successful peace mediation process and successful Finnish mediation skills. In 2010, it gave a whole new symbolic meaning to the white paper on peace mediation published by the Ministry for Foreign Affairs (Jauhola 2016): Finland was entering a global sphere of peace mediation powers. But as I suggest elsewhere (Jauhola 2020), this symbolic moment can also be disrupted with a feminist gaze, instead of the handshake, focusing on the wider framing of the original photograph by photographer Jenni-Justiina Niemi, and the portrait of a European woman hanging 


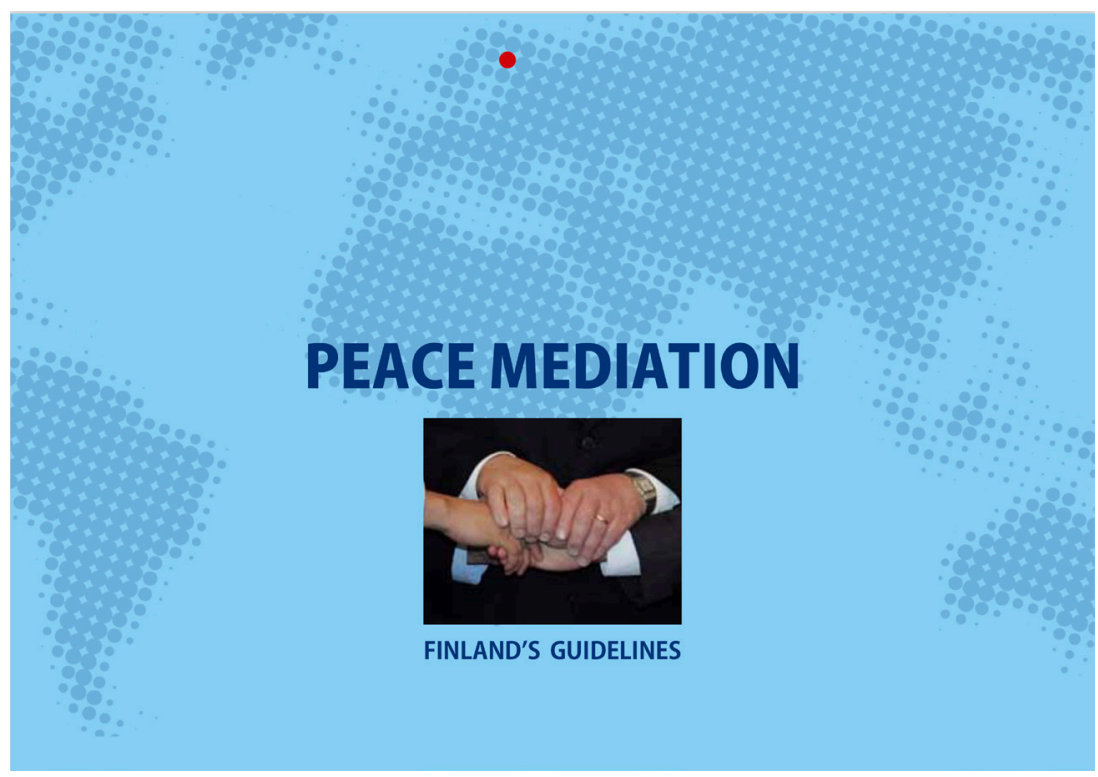

Image 1: Helsinki MoU handshake used in the peace mediation white paper in 2010 .

Source: Ministry for Foreign Affairs 2010.

on the back wall of the ceremony hall. This unknown woman from Paris, who sits on a chair holding flowers and staring the international media, and the cameras, with a serious face is the 1863 painting by Erik Johan Löfgren entitled as La Rêverie - woman in a 18th century dress. La Rêverie translates into English as a daydream or daydreaming. ${ }^{3}$ Yet interestingly, the word La Rêverie derives from a Middle French word that carries meanings of wild speech, delirium, and rever that means "to roam, speak wildly". ${ }^{4}$ Middle French word "rever" is also the source of the English word rave - that is used to refer "to speak or shout in a way that is out of control", usually because of anger or mental illness, but also "to express praise and admiration for someone or something enthusiastically". In the spirit of politics of subversion (Jauhola 2013,9) and such potentiality offered by the refocus on $L a$ Rêverie, raving disguised into daydreaming, I invited two Acehnese women, Professor Eka Srimulyani and activist Donna Swita to the yellow 'MoU signature' room in Smolna:

Marjaana: welcome to the 'MoU hall'. This is very emotional for me, as I've waited for 10 years to receive guests, friends, women from Aceh to visit this place. Because this place, or stories about this place in Aceh and MoU Helsinki are many in Aceh, but only few have had the chance to visit the place, and to reflect on the process of negotiating the peace ... Maybe we can continue discussing what's the core content of MoU 
because it is clear to all who read it, that there is nothing on women, women's rights or traces of women's aspirations in it?

Eka: Reflection that is based on my interviews in which the interviewees acknowledged that women were not included in the negotiated result and that the only thing they were able to think of at that time was the warring parties. This was exactly what one women's right advocate said: the peace focuses on the warring parties and conflict victims, people outside of the two conflicting parties, are forgotten ... here is no process to absorb the aspirations of what is actually desired by the people of Aceh. It does not only mean marginalisation of the group of women, but also of other civil society groups because peace is a peace perspective of two warring parties, thinking adopted by the organisation that mediated the peace.

Donna: Women were not included, just the two warring parties were included, GAM and Indonesian Government. Women's views were not included, although women had held the Duek Pakat Inong Aceh (Second Acehnese Women's Congress) [in 2000 and again in 2005]. Women['s groups] were not invited to nor participated in the MoU process, despite the fact that women had initiated a consolidation process. During the conflict, when we queried the warring parties, what about the female and child victims of violence, or parents and other affected people, they replied to us that it is a struggle that requires casualties and those are a consequence of the struggle. So they were shifting their position: we must support their struggle, but they do not speak of our perspectives when they are at the peace table. After the MoU, the governance law was prepared. In one of the articles is mentioned that there will be justice throughout society Aceh. This is actually justice for all Acehnese, it means men and women, not just men, there are also women in Aceh.

In the video MoU Helsinki: reclaiming back history, three women reflect on inclusiveness of the Aceh Peace Process in Helsinki in 2015. Recorded at the site of the signing ceremony of the Helsinki MoU, Marjaana Jauhola interviewed Professor Eka Srimulyani and Donna Swita, who were working at the time of the recording for Solidaritas Perempuan (Women's Solidarity for Human Rights) - two Acehnese women who met in Helsinki for the first time. The video reflects on the gendered armed conflict and the peace process that provided limited space for incorporation of Acehnese women's experiences and demands, despite the strong leadership and initiative by Acehnese women before the December 2004 tsunami. The video portrays two different forms of feminism: one that draws from the engagement with academic and grassroots-level Islamic feminism and portrays a picture of women's leadership in Islam in Aceh; and another which is centred around feminist human rights' work and critical engagement with that of the state structures, such as the celebration of Hari Ibu (Mother's Day or Women's Day) in the streets of Jakarta, 


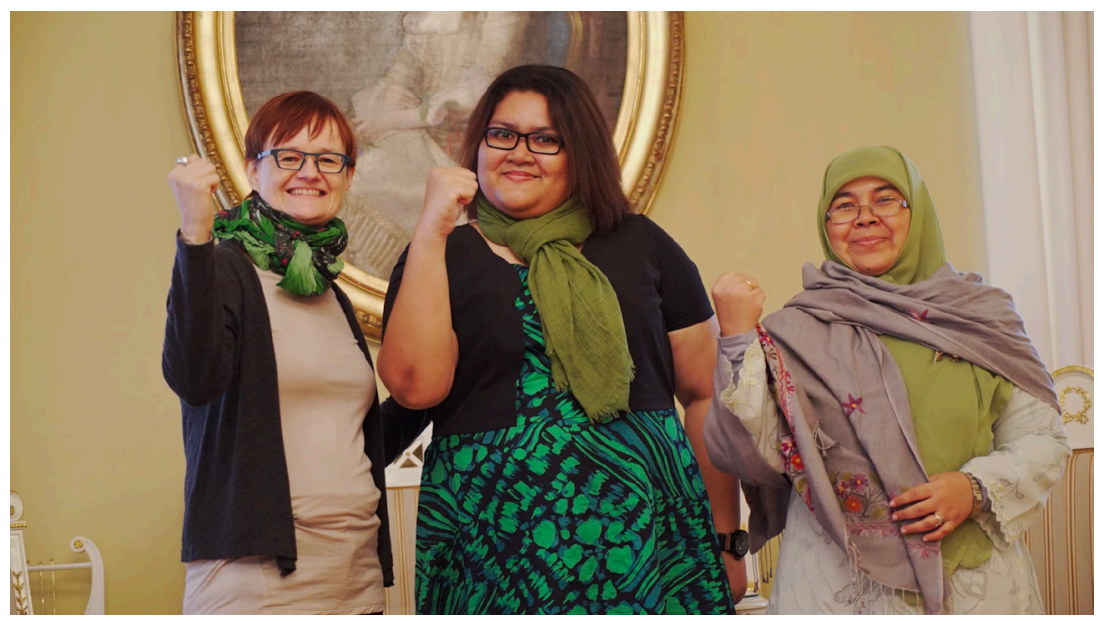

Video 3: MoU Helsinki: reclaiming back history (16:52).

Source: Scraps of Hope.

To watch this video, scan the QR code with your mobile device or visit DOI: https://doi.org/10.33134/pro-et-contra-1-video-3

and the political economy of the peace in Aceh and the wider ASEAN (Association of Southeast Asian Nations) region and the formation of the ASEAN Economic Community AEC (Masyarakat Ekononomi Asean, MEA).

\section{Outline of the Argument}

With the focus on everyday contestations over the rebuilding of the city in the aftermath of the decades-long armed conflict, struggles for equality and justice, repetitive interpretations over the meanings of good life and the politics of decolonising the peace, the book aims to contribute at least to the following scholarly debates: the gendered and intersectional everyday of peace, Islam and political economy; post-conflict and post-disaster urbanisation; and the biopolitics of reconstruction and recovery.

The chapters that follow witness the emergence of foolish knowledge (Ilmu Bodoh), subaltern theorisation on equality and justice, allowing the emergence of alternative interpretations of what decoloniality in Aceh might mean. What emerges is not a coherent nor the whole story of the city of Banda Aceh. Rather, the pages that follow provide fragments and multiple voices (Jauhola 2015b, 743, quoting Waterson 2007, 27), each contributing to lived subaltern perspectives on the contested city. Ethnographic encounters and researchers' analytical focus is tuned into negotiations and co-constituted intersections of class, social status, ethnicity, gender and sexuality, and the specific ways in which these intersections, both visible and hidden, are forged and contested 
in concrete social settings in the everydayness in the city of Banda Aceh 7 to 13 years after the peace talks in Finland.

Chapter 1 provides an overview of the recent literature on subjectivity, agency and freedom in feminist research on Islam and the ethnographic study of the everyday. It engages with Foucauldian feminist theory and Islamic feminism - especially with the works that are inspired by Saba Mahmood's (2012 [2005]) book Politics of Piety, focusing specifically on the analytical and methodological research focus on the da'wa or piety movement in urban Cairo, but also close reading of the debates around the Iranian Revolution and Foucault's (Afary and Anderson 2005) analysis of it. The chapter then suggests that - by engaging with seemingly contradictory and oppositional claims on agency and freedom, and by practising alertness that ethnographic writing may reinforce binary traps and logics of dichotomies and divisions such as modernity-traditionalism, secular-religious/Islamic/Islamist - it is possible to practise an ethnographic methodology, study of the everyday, in ways that can illuminate the multiple and at times conflictive and contradictory struggles made in pursuit of a good and meaningful life. Further, taking conceptual clues from post-colonial critique of ethnography, visual representation and knowledge production practices, the chapter turns a critical eye on research praxis by proposing reversed research methodology, embracing foolish knowledge (Ilmu Bodoh) $)^{5}$ and nurturing co-creative moments of ethnographic encounters. The reversal, it is suggested, resists forms of hegemonic, militarist masculinity embedded in the peace, and the branded peace mediation, and highlights the limitation of academic knowledge production dominated by English-speaking foreign scholars.

Chapter 2 enters the city of Banda Aceh at a strategic moment when its leadership was actively constructing the city and its citizenry as kota madani - a civilised Islamic city, as part of their Islamic populist post-conflict and post-tsunami politics. Following in the footsteps of the legal frameworks governing gendered and sexualised bodies, articulations of the female mayor Illiza and a number of civil society actors, the chapter focuses on the ongoing contestations over the ideal city, its gendered citizenry and notions of piety. The chapter follows articulations over the Civilised City, such as amar ma'ruf nahi mungkar, enjoining what is right and forbidding what is wrong, but also concrete ways that Mayor Illiza, as a populist female leader, provided advice and acted as a role model for the ideal Acehnese womanhood. The chapter further illustrates how such notions were contested in the public sphere by other movements such as Hizbut Tahrir's transnational Women and Shariah Campaign, and International Women's Day demonstrations focusing on diversity and non-violence.

Chapter 3, together with all the life-historical videos located in different chapters of this book and produced as part of this urban ethnography, are dedicated to the lives and struggles of women, who would often be labelled by outsiders as 'failed', 'oppressed' or 'resilient'. The women's stories narrated 
and reconstructed in this chapter and in the short life-historical videos take place in different locales in the city, but what is common among them is that they take place in the space of lower-middle classness or aspiring middle classness, or in an economic struggle to regain the status of a middle-class, respectable woman in the eyes of the wider society and the neighbourhood in particular. The focus here is on more mundane experiences of slipping out of the ideal womanhood constructed through notions of kota madani or management of self through akhlak (practice of virtue, good character), but which are not reducible to their own perception of their religiosity. The aim in the narration is to show the complexity and messiness of lived experience, but also to zoom in on mundane attempts to make lives livable, and negotiate space within the social networks available in the city of Banda Aceh. The videos further illustrate these struggles and negotiations.

Chapter 4 focuses on urban masculinities and the ways in which they are performed and negotiated as an ideation-shaping force ${ }^{6}$ as part of the ongoing peace process. The chapter examines expressions of violence, care and healing in the midst of postcolonial continuities of economic grievance and quests for social justice. The narrative follows lives of two ex-combatants, one in his $60 \mathrm{~s}$, the other in his early 30 s, and the ways in which they negotiate their belongingness to the ongoing peace process and its political, economic and violent consequences. What did the first generation of the Free Aceh Movement (Gerekan Aceh Merdeka, GAM) combatants dream of? And what does the decade since the peace settlement look like from their perspective? The chapter gives perspective to the post-conflict practice of premanisme or gangsterism in the city among men who showcase their power through extortion, fear of violence and patron-clientelism. The chapter argues that the political and economic contradictions of the peace, as experienced and witnessed with lower-ranking excombatants, reveal an ideological conflict between what the war effort signified for the former GAM recruits and what the realities of everyday lives in peacetime have turned out to be. The chapter ends with theorising about foolish knowledge (Ilmu Bodoh) or subaltern knowledge, oral transmission of Kitab Mujarabat as narrated by the Sufi healer. This knowledge is excluded from the dominant discourse of vernacular forms of reconciliation, care and healing, but is intimately connected to the oral transmission of Malay traditional healing practice and to the 40-year-long war against Dutch colonialism, known as the 'Dutch War' (Perang Beulanda), the 'Infidel War' (Perang Kaphé) and the 'Holy War' (Perang Sabil). The three documentary videos continue engagement with the Sufi healer and his analysis of the contradictions of peace in Aceh.

Chapter 5 offers insights into the lives of street punk and metal communities in Banda Aceh who gained worldwide fame after the mass arrests and re-education of punk adherents by Mayor Illiza and the municipal government in December 2011. It follows the lives of both male and female punks from the Tsunami Museum to the prison and the court house, from the punk community to that of the global punk solidarity movement and back: from their tattoos 
to their songs describing Acehnese post-conflict realities in which impunity, corruption, militarised everydays and the transnational online punk community are embedded - thus keeping the traumas of the city open. The chapter examines the case of the arrest of several punks in Banda Aceh in November 2013, known locally as the 'Rex incident', and the criminal proceedings that followed it. The attention is on mundane experiences of structural and physical violence and the obstacles, resourcefulness and ways of coping after the hype of the global punk solidarity campaign of 2012 had passed. Drawing attention to silences in global solidarity efforts and the local media when the 'Shari'a morality vs. the right to be punk' issue is not in focus, the chapter challenges such binaries, arguing that they hinder understanding of the everyday experience of punk, and overlook the wider misuse of state power, violations of rule of law and the violent political economy in the post-conflict context of Aceh. Thus, it is argued that the punks in Aceh are constantly studying the hierarchies and relations of power through their embodied and gendered existence in the city. A focus on their everyday experience draws attention to their active negotiation of space and agency within such globalised hierarchies.

Chapter 6 focuses on the gendered and sexual post-conflicted politics in Aceh from the point of view of the Acehnese queer: 'LGBTI activists', but also non-activist individuals who do not conform to heteronormative and binary gender ideas put forward by the post-conflict legal frameworks or their advocates. As with other marginalised subjectivities, the paradox of visibility follows queerness in Aceh: becoming visible is required for receiving care, or gaining access to basic social, political and economic rights, and thus forms an important part of advocacy, such as on HIV/AIDS, or demands for access to education and livelihoods. Yet, this same visibility causes discrimination and fear of exposure. Thus, the story that unfolds in the chapter can be read as an awkward paranoia and embodying the pain of (re)creating unsafety, negotiation on the principles of respecting and maintaining safe spaces and invisibility, simultaneously responding to the desires of becoming heard, understood and visible. Moving from activist spaces and spheres to beauty salons and beauty contents, but also hazardous work and low-wage labouring (see Chapter 7) and care for others, these snippets of life-historical narratives highlight the multiple faces of the queer in Aceh which cannot be reduced to a narrative of LGBTIs in need of saving - let alone a homogenous group whose demands, dreams and fears can be easily translated into 'global LGBTI' advocacy vocabulary.

Chapter 7 follows the journey of a plastic bottle from glossy advertisements to neighborhood kiosks and supermarkets, to its consumers at state bureaucracies, university campuses and homes, to recycling sites and waste management. What cultural changes have the tsunami and the increased commodification of water brought with them, and in what ways does bottled water connect the different social and economic classes in the city? How do bottled water or recycled cups form biopolitical regimes of living and how do such arrangements shift norms, our thinking and, simply, cultural and material practices? Firstly, 
following the economisation of the polyethylene terephthalate (PET) bottle, or the life of the bottle, allows us to see connections and disconnections of the city: the symbolic construction of the middle-class ideals and piety, the connectedness of consumption and waste in the livelihoods of the lower-middle classes and the urban poor, such as the queers who struggle to gain respectability, and beholding their dignity and piety in the city. These trajectories provide a glimpse of foolish knowledge (Ilmu Bodoh) in action, subaltern narratives of social rafting: management of daily life and livelihood strategies in the urban post-disaster landscapes. This knowledge also challenges the multidimensionality, or the shadows of the political economy of the bottled water, by providing both sharp criticism of the assumed normalcy created in the city, but also by offering, as Dedi's story illuminates, insights into the practice of Islamic piety, and non-violent and egalitarian visions for the future.

Lastly, the Conclusions section of this book brings together reflections on the results of 10 years of peace-making in the city of Banda Aceh. How does the focus on the everyday of the outcast and the invisible challenge the narrations and ideals of a city that was 'built back better'? What alternative futures can their stories illuminate? And how does ethnographic and documentary-film story-telling provide ways for a decolonised dialogue on peace? Following foolish knowledge (Ilmu Bodoh), a subaltern theorisation of equality and justice, the last pages of this book turn to iterations of what decoloniality of peace in Aceh might mean in the future. 


\title{
CHAPTER I
}

\section{Stumbling Scholarship}

\author{
Reversing Research Praxis \\ of Everyday Subjectivities
}

\subsection{Researched Subjects and Postcolonial Paranoias}

It galls us that Western researchers and intellectuals can assume to know all that it is possible to know of us, on the basis of their brief encounters with some of us. It appalls us that the West can desire, extract and claim ownership of our ways of knowing, our imagery, the things we create and produce, and then simultaneously reject the people who created and developed those ideas and seek to deny them further opportunities to be creators of their own culture and own nations. It angers us when practices linked to the last century, and the centuries before that, are still employed to deny the validity of indigenous people's claim to existence, to land and territories, to the right of self-determination, to the survival of our languages and forms of cultural knowledge, to our natural resources and systems for living within our environments.

Tuhiwai Smith 2008 [1999], 1

If women in question had been able to speak, we would probably have ended up with a multiplicity of different opinions and voices. Both the British and the Indian positions, however, reduce that complexity into one voice, casting the women in question as a homogenous group and committing thereby an act of epistemic violence.

Spivak 1988, 280-281

The recent rise in calls to indigenise and creolise academic methods, theory and knowledge production processes (see, e.g., Gobo 2011), and primarily $\mathrm{BAME}^{1}$ student-led campaigns, such as Why Is My Curriculum White? (WIMCW), ${ }^{2}$ \#GenderJustice ${ }^{3}$ and 'Decolonising Our Minds', ${ }^{4}$ have demanded 
that academic institutional structures and processes, teaching syllabuses and research methodologies be decolonised and diversified (see also Bhambra et al. 2018). Revisiting (European) intellectual practices and research imaginaries has prompted a critical appraisal of the colonial continuities in the racial division of labour whereby research data (raw material) continues to be extracted from the Majority World countries for consumption in the Global North (Connell et al. 2017a, 2017b). Reaching a new peak in the past few years, such works (feminism and gender studies included) draw on and benefit from the scholarship and activism in recent decades on critical race and postcolonial theory within the humanities and social sciences (Mohanty 1984; Loomba 1998; Sidaway 2000; Mohanty 2003; McEwan 2009).

Furthermore, in Europe, these initiatives are taking place at a juncture where political debates on the 'refugee crisis' rarely contextualise the situation as a continuum of European colonial history (Visweswaran 1994; Kenway and Fahey 2009; Bhambra 2014, 2015; Connell et al. 2017a) - despite the availability of scholarship that analyses migration through the lenses of racialism and post-colonialism (Keskinen and Andreassen 2017). In a paradoxical application of double ethical standards, as the European Union establishes deadly racialised borders on its shores, it simultaneously funds initiatives that aim to promote 'fair research' and diminish 'ethical dumping' (Trust Project 2020). New challenges have emerged as the past decade has witnessed a rise in populism, authoritarianism, nationalism, racism and white supremacy, at the same time as space for critical scholarship in higher education is being reduced in the name of austerity and neoliberal efficiency. Troublingly, some of the challenges have appeared within academia itself, as demands for justice, equality and equity in academia and on campuses are met with the argument that they threaten freedom of speech and progress of scientific knowledge production. ${ }^{5}$

How should one react amid such paranoia? Stuart Hall's observations are one place to start:

[T]he so-called colonial world is still unfolding - more accurately, unravelling - inside the post-colonial, in the wake, in the devastating aftermath, of an untrascended colonialism: a disaster-littered, protracted, bloody and unfinished terrain which, in its globally transformed state, still occupies our world.

Hall 2017, 24/265

In the case of the colonial and the post-colonial, what we are dealing with is not two successive regimes but the simultaneous presences of a regime and its after-effects. Colonialism persists, despite the cluster of illusory appearances to the contrary. 
The present still carries the spectres of the past hiding inside it.

ibid., 25/265

The initial postmodern and postcolonial critique of ethnographic methods in the 1980s and 1990s, also described as the crisis in anthropology, has since produced reflexive debate concerning the possibilities and restrictions of ethnographic endeavours to understand lived and embodied knowledge practices. This has produced a renewed focus on power, exploitation and colonial reproduction, on the one hand, and the possibilities of resisting the Enlightenment-driven ontologies without having to discard the method altogether, on the other. 'The desire was not to know the other as other, or to study the other as a way of knowing oneself, but to understand how previously marginalised groups existed in the circuits of meaning, cultural formation and structural location' (Skeggs 1999, 36, emphasis added).

Further, to counter possible subordinate circuits of 'othering', Meera Sabaratnam (2017) offers a methodology of involving the reconstruction of subjecthood, aiming to address the critique, and impact, of Eurocentrism in academic knowledge production. By subjecthood, she means 'the property of having one's presence, consciousness and realities engaged in the analysis of the political space' (Sabaratnam 2017, 39). Focusing on the possibilities of becoming subjects through research allows more systematic rethinking of what the research process itself should entail. At the heart of this process is the recognition and recovery of historical presence, political consciousness and material realities (ibid., 39-47). Sabaratnam suggests that epistemological 'standpointism' (Harding 2004) would allow scholarship to 'embrace the partial, limited, embodied and situated nature of knowledge practice but radically expand [those] whose perspectives and experiences [are] considered useful, [and] worthy of attention' (Sabaratnam 2017, 48 emphasis in the original). The requirement of strong objectivity 'creates a form of political triangulation for claims about the world and requires knowers to think about overlaps, resonances and tensions between positions. Science must therefore understand itself as polyphonic, politicised and plural' (ibid., 48 emphasis in the original). ${ }^{6}$

This resonates with Spivak's warning quoted at the beginning of the chapter, of the danger of reducing complexity of women's voices into one, as portraying them as a homogenous group constitutes what she calls an act of epistemic violence (Spivak 1988). Sarah Bertrand (2018, 282) has further suggested that, firstly, the focus on 'silences' in critical scholarship constitutes a colonial relationship in the form of silencing: when subalterns cannot speak, when the subalterns are not listened to and when subalterns cannot be heard or understood. Secondly, well-meaning attempts to give voice to these silenced groups easily ends up as 'speaking for', which constitutes another form of silencing that 'reproduces historical dynamics of domination and exploitation' (Bertrand 2018, 29; see also Harman 2019, 19). 
Further, instead of assuming that such colonialist or imperialist standpoints, positionalities and hierarchies are identifiable, knowable and communicable prior to the research encounter, scholars have suggested that positionalities and differences in research gain their meaning 'right here and now' through social practice (Elliston 2000; Moran et al. 2001; Penttinen 2013; Puumala 2013) and embodied knowledge (Moore and Mathias 2016). We, as researchers and researched, are produced through our experience (Skeggs 1999, 39, 42), and this experience must be translated into a perspective before it can become a standpoint (Moran et al. 2001, 432).

These observations lie at the heart of this research endeavour that aims to embrace polyphony and pluralism, and actively engages with privileges as failure. Yet, this research originated in the neoliberal academia of the Global North, using research methods such as ethnography and visual documentarism to strategically constitute research praxis that embraces failure, co-creation and critical reflection to create openings for a reversal of roles. To narrate such openings, this chapter draws on the labouring of, mostly racialised, scholars who have pushed postcolonial critique to become critical academic knowledge praxis and the renewal of research methods, epistemologies and ontologies. This chapter suggests that ethical and engaged research praxis, which I will call 'stumbling scholarship', requires, firstly, that one embraces failure, and, secondly, that one engages with such research encounters and knowledgecreation ${ }^{7}$ forms that allow the analytical process to be kept open to critique and new co-creative meaning-making.

I start with an overview of the existing literature on subjectivity through the lenses of academic literature on feminism, Islam, agency and freedom - which are in later empirical chapters theorised through the ethnographic subaltern encounters - or what the Sufi healer (see Chapter 4) calls Ilmu Bodoh, translated for the purpose of this book as 'foolish knowledge'. I then move on to articulate what decolonialised or reversed research methods are, could or should be, and continue with a reflection on what it has meant for this research process concretely in its different phases/stages, in order to resist forms of hegemonic militarist masculinity embedded in both the peace and the branded peace mediation.

\subsection{On Everyday Subjectivities: Feminism, Islam, Agency and Freedom}

Over the years, rich academic research on post-tsunami Aceh has been conducted both locally and outside the region: ethnographic and anthropological accounts of the aid effort and the politics of humanitarian aid (Grayman 2012; Grossmann 2012; Jauhola 2013); studies focusing on the role of religion, religious movements and Islamic politics in the aftermath (Ichwan 2007; Salim and Sila 2010; Feener 2013; Kloos 2017); analysis of the armed conflict and peace process in Aceh, focusing in particular on the latter's political economy 
and the transformation of combatants into the politicians, governors and businessmen of the province (Aspinall 2009a, 2009b; Miller 2009; Törnquist 2009; Stange and Patock 2010; Sindre 2014); and Acehnese nationalism (Syamsuddin 2013). Several of these scholars have also addressed the policy rhetoric of 'building Aceh back better' adopted by humanitarian organisations and the Indonesian Government as part of post-tsunami reconstruction efforts (Daly et al. 2016) and globalisation of aid response (Jauhola 2013), but also of recipients of the aid (Smith 2017). With the financial and strategic policy emphasis on tsunami reconstruction, however, conflict reconstruction has been marginalised and politicised in the overall disaster response (Waizenegger and Hyndman 2011). Acehnese scholars have contributed to these discussions through empirical research, but also with theoretical inputs drawn from reviews of Aceh studies, or 'Acehnology', and understandings of Islamic articulations of agency (Bustaman 2011; Srimulyani 2014). The younger generation of Acehnese scholars are yet to publish their research findings and it is clear that the first decade of reconstruction has primarily accelerated foreign researchers' careers (Missbach 2011). This situation rightfully raises a number of political and ethical questions connected with knowledge production processes, such as those inherent to ethnographic research - ways of publishing, power and authorship - to which I return on a number of occasions in this book.

Whereas the majority of previous studies on Aceh have focused on emerging subjectivities vis-à-vis the tsunami experience, I have attempted to practise openness when approaching the lived and experienced city in my ethnographic research - what I call ethnography of the 'here-and-now' (Jauhola 2015a) acknowledging the possibility that other historical and personal experiences, or material and spatial references, may emerge as significant topics or themes of discussion during the ethnographic encounter. The research discussed here aligns with ethnographical approaches that have abandoned the formerly dominant mode of 'realism': that is, that a coherent account of whole societies is achievable. Instead, the focus is on the fragments and multiple voices of the city (Waterson 2007). Focusing on the micro-level and its detail enables the construction of a better understanding of the histories, socio-cultural orders and social dimensions of the conflict and tsunami aftermaths. Thus, I approach the city of Banda Aceh from the perspective of the experienced and lived everyday, understanding this and the social practices it produces as an active site of struggle and contestation over legitimate subjectivities. In true ethnographic fashion, I also make the claim that it is the ethnographic encounters in Aceh that matter most and, therefore, the chapters that follow examine research encounters in and on Aceh, yet they also draw connections to other locales, whether academic or lived experience, in order to make such connections and disconnections visible: not always in a linear fashion, but perhaps rhizomatically.

Recent anthropological accounts that have given voice to people's stories of their lived experience in reconstructed neighbourhoods of Banda Aceh (Kloos 2017; Samuels 2019) have made it clear that, as noted above, the impacts of 
natural hazards are complex products of social, political and economic environments which are irreducible to simplistic, linear and 'one-description-fits-all' narratives. Such works take issue with secular-liberal (feminist) theorising on subjectivity, stability, rational choice and individualism, offering instead Acehnese concepts such as muslihat (achieving one's goals through ancillary or indirect means), sabr (perseverance in the face of adversity) and al-haya (reticence or modesty, piety) or 'inner Islam'; thus, everyday subjectivities are regarded as alternatives (Siapno 2002; Jauhola 2013; Taylor 2015; Kloos 2017; Samuels 2019). These works are critical of drawing purely upon Western feminist theorising within the anthropology of disasters and religion, but also on feminist political and Islamic studies. Instead, I suggest that they produce forms of scholarly resistance to Eurocentrism in the shape of hybridising or creolising theories (Gobo 2011, 428). My aim here is to widen such discussion to include analysis of post-disaster/conflict politics and international interventions (see, e.g., Sabaratnam 2017).

Over the past decade, much has happened in Foucauldian feminist theory and Islamic feminism, but also in the analysis of Islam, Islamist revivalism, political Islam, governmentality and modernity, and not just in the spheres of feminist theorising, but also feminist activism. My aim here is not to discuss these analyses in detail in order to prove one of them 'right', but, rather, to illustrate how, by engaging with seemingly contradictory claims, it is possible to promote an ethnographic methodology that critically reflects on the binary traps and logics of dichotomies and divisions such as modernity-traditionalism, secular-religious/Islamic/Islamist; it also supports the assertion that ethnographic study of the everyday can illuminate the multiple and at times conflictive and contradictory struggles made in pursuit of a good and meaningful life. Here, I strategically draw guidance from two sources: firstly from the late Eve Kosofsky Sedgwick's (2003) work that challenges the theoretical, but also empirical tendency to read phenomena, encounters and events as paranoid, and suggests practising scholarship through reparative reading practice instead. Secondly, I return to Foucauldian debates around feminism, agency and Islam, reflecting on Saba Mahbood's analysis of the Egyptian piety movement and Foucault's reports of the Iranian Revolution. Sedgwick regards paranoid tendencies in academia as intimately connected to the paradigmatic approach labelled the 'hermeneutics of suspicion' by Ricoeur, which is the intellectual heritage of allmale thinkers such as Marx, Nietzsche and Freud (Sedgwick 2003, 124-125). Sedgwick summarises the paranoid paradigm as an anticipatory, reflexive and mimetic strong theory, and a theory of negative effects that places its faith in exposure (ibid., 130). Reparative reading, on the other hand, 'is to surrender the knowing, anxious paranoid determination that no horror, however apparently unthinkable, shall ever come to the reader as new' (ibid., 146, emphasis in the original); 'it wants to assemble and confer plenitude on an object that will then have resources to offer to an inchoate self' (ibid., 149); and 'it undertakes a different range of affects, ambitions, and risks ... the many ways selves and 
communities succeed in extracting sustenance from the objects of a culture even of a culture whose avowed desire has often been not to sustain them' (ibid., 150-151). Interestingly, this approach resonates with the Islamic practice of istilah, defined as 'a crucial notion of method of Islamic legal philosophy that is geared toward finding good in each situation, by mediating between contending positions, and shepherding the larger process of achieving balanced solutions that constitute the common good for the involved parties' (Salvatore and LeVine 2005, 2). What follows over the next few pages is an attempt to practise reparative reading of two works that have informed much of the most recent debates on feminist readings of agency, becoming subjects, Islam, and social and political reforms: Politics of Piety by Saba Mahmood (2012 [2005]) and a reprint of Foucault's writings on the Iranian Revolution (Afary and Anderson 2005).

In Politics of Piety, an ethnography of the da'wa or piety movement in Cairo, Saba Mahmood took issue with poststructuralist feminist theorising - in particular the work of Judith Butler - which 'locates agency in the political and moral autonomy of the subject, ${ }^{8}$ and thus, according to Mahmood, remains problematically grounded in secular liberal theory, trapped between a binary of subordination and subversion (Mahmood 2012 [2005], 17-22). As an alternative, Mahmood offers a reading of Foucault and of positive ethics that focuses on capacities and locates agency in the efforts of cultivating the self 'within' normativity, and thus unlinks agency from the goals of liberal feminist progressive politics (ibid., 29-34). In her response to Mahmood a year later, Butler (2006) addressed the question of subversion, the autonomous self and Mahmood's understanding of docile agency: although subversion is often taken as a tactic that is deliberately instrumentalised by a subject for an explicit purpose, that is not how she, Butler - or Foucault for that matter, uses the conceptualisation of power and subjectification. Rather:

Even when there is agency, it is a vexed one, since one is mired in the discourse that makes one's agency possible and so never fully distanced from it as an instrumental relation would imply. This is the meaning of the paradox of subjection, since one depends upon that very norm to be formed as a subject and an agent even as one struggles against the conditions of one's own formation.

Butler 2006, 285

Similarly, in Volume 1 of History of Sexuality, Foucault argued:

Where there is power, there is resistance, and yet, or rather consequently, this resistance is never in a position of exteriority in relation to power. Should it be said that one is always 'inside' power, there is no 'escaping' it, there is no absolute outside where it is concerned, because one is subject to the law in any case? 
Thus, understood in this way, transgression does not necessarily refer to the 'resistance of free agents' or agency understood in libertarian ways, but rather points towards the process of 'subjectification', becoming a subject. Thus, in response to the Egyptian piety movement, speech acts - Mahmood using this term to refer to both oral or textual enunciation, but also bodily acts - can be, according to Butler, 'at once an act of conformity and something new' (Butler 2006, 286).

Seven years later, in 2012, in a new preface to Politics of Piety, Mahmood responded to part of the critique she had received of her conceptualisation of agency, clarifying that what she aimed to argue was that 'disciplines of subjectivity pursued by the pietists profoundly parochialise conceptions of the subject, autonomous reason, and objectivity through which the pietists are understood to be lacking in faculties of criticism and reason' (Mahmood 2012 [2005], xii). Rather than being centred around the question of 'agency', therefore, she reiterates her interest to be in: 'a) the kinds of capacities embodied, rational, technical - these various modalities of agency require; and b) the conceptions of the body, personhood, and politics these capacities presuppose, enable, and construct' (ibid., $\mathrm{x}$ ).

This is precisely how Mahmood is read in Aceh, including by sociologists of religion at the Islamic State University Ar-Raniry (Srimulyani 2014). Some younger, unpublished scholars have remained cautious, however, about the possibility of the notion of docile agency providing sufficient theoretical framing in analysing the gendered politics of Aceh. In a similar fashion, Mahmood's analysis of everyday piety is critiqued for lacking diversity. In Aceh, conceptualisations of agency need to be put into the context of a re-politicisation of the private sphere and the adoption of post-conflict legal frameworks producing jurisdiction that renders certain gendered and sexualised bodies and their desires illegitimate and immoral, meanwhile legitimating state violence targeting both Muslims and non-Muslim minorities; yet, at the same time, it is apparent that transnational Islamist revivalism, the da'wa movement and the focus on gendered piety are providing new openings for the care of the self and agency for others.

Given this complexity, I want to focus on the critique that Mahmood's articulations of agency and the capacity approach has received elsewhere - not so much to downplay the value of the tools offered by Politics of Piety to feminist analysis of politics and agency, but, rather, to contextualise and relate Mahmood's ethnographic encounters to the Cairoean piety movement, at a particular point in time and of social organising, to questions of governing the self and the role of the da'wa movement as an aspect of Muslims'social and political lives. I do this following Meera Sabaratnam's notions of local and everyday in which the engagement with diverse groups of those targeted by interventions is not to gather raw data to be analysed in Western universities, but to present their voices in relation to a wider structure of inequality in a dialogical 
fashion: during the 'data collection' rather than after, and usually in disconnected ways (Sabaratnam 2017, 30-31).

This is done in order to propose perhaps more fluid and contradictory ways that agency can be studied, given the multiple religions, self-identifications and modes of striving towards the good life in one locale: not only within a movement or in legally articulated ways of 'becoming-subject', but also in ways that are considered either illegal, forbidden or suspicious. Further, to 'make visible the manner in which subjects and populations placed in positions of temporal belatedness, or outside of time altogether, have "defied, deflected and appropriated" their temporal emplacement' (Rao 2020, 26). Thus, interest does not lie so much in how well the Acehnese inhabit the category of 'pious' or 'piety' or how such attempts are constructed elsewhere (in Western media) to illuminate the essential violence of political Islam (Agnes 2012); rather, the goal is to illustrate the negotiations and co-constituted intersections of class, social status, ethnicity, gender and sexuality, and the specific ways in which these intersections, both visible and hidden, are 'forged and contested' in concrete social settings (Kang 2010; Agnes 2012, 33-34).

Firstly, Mahmood is criticised for forcing the reader to choose between the binary positions of a 'Western liberal feminist' and a 'member of the piety movement'. This appears to be a false simplification of both forms of feminisms and available Islamic/Islamist positions, including a number of feminisms that do not subscribe to modernist or liberal forms of agency/subjectivity or to what Sindre Bangstad calls 'bitterly contested' fields of power in Egypt (Selim 2010; Bangstad 2011; Jauhola 2013, 2015a). Exploration of the map of feminisms or diversity of movements in Egypt is absent from Mahmood's work. Secondly, Bangstad calls for a more in-depth discussion of the da'wa movement in other social spheres besides the ritual, particularly relating the movement to urban and middle-class Cairo, or 'well-off Egyptian women', in order to make the class struggle, or bourgeois self-making, more visible (Bangstad 2011, 217, for detailed analysis of the movement in Cairo's new popular quarters see Salwa 2006). ${ }^{9}$ Other ethnographic works from Egypt and beyond have further suggested that urban Muslim social imaginaries and presentations of self are more fluid and porous than Mahmood's account perhaps suggests (Ismail 2006; Kandiyoti 2009; Bangstad 2011; Schielke 2012, 2015).

Consequently, Sindre Bangstad reads the silence of hesitation in Mahmood's work to be partly researcher's self-censorship - the ethnographic refusal to disclose the findings of one's research to protect the research subjects from political fallout - in favour of focusing on such stories and moments that reconfirm the idealised image of dawa followers (Bangstad 2011, 217; for a detailed discussion of ethnographic refusal, see Ortner 1995). Sherry Ortner's original article on ethnographic refusal makes a rather humble, but important suggestion: to understand gender politics in a given societal context and historical temporality, it is important to 'attend to [the subject] as a person, subject, agent, 
or any other form of intentionalized being ... her understandings and intentions (not to mention her societal universe, her history and so forth)' (Ortner 1995, 185-186). Further, context and temporality matter, as recent research from post-25 January Revolutionary Egypt suggests, young members of the Muslim Sisterhood have adopted gender politics that have feminist undertones, if not calling them such (Biagini 2020).

How, then, should unfolding societal transformation be ethically read and contextualised? Another book was published at the same time as Politics of Piety, with the title, Foucault and the Iranian Revolution: Gender and the Seductions of Islamism, by Janet Afary and Kevin B. Anderson (2005). The major part of the latter book is devoted to critiquing what the authors perceive as the naivety of Foucault in his reading of the politics of the Iranian Revolution and illustrating how his writings on Iran have informed his later thinking on power and modernity (for a detailed critique of this analysis, see, e.g., Rahimi 2006). The book presents a peculiar selection from French feminist critiques of Foucault in 1978 to 1979, and it seems that what it principally accomplishes is a problematic construction of a relationship between Foucault and secular feminism(s) that considers any (leftist) alignment with questions of religious Islamic subjectivity to be problematic, culturally relativist and, essentially, antifeminist. ${ }^{10}$ In contrast, other readings of Foucault of the period point interestingly to his attempt to build a theory of multiple modernities, or multiple projects of modernity, with the effect that 'modernity becomes a multivalent set of practices, beliefs, and institutions often at odds with one another rather than a simple, univocal ... discourse of modernity that is polyvalent: modernities expressed in multiple practices that reinforce existing power relations and those that contest them' (McCall 2013, 28-29). This way of understanding the modern allows 'the West' and its culture to be conceptualised as consisting of 'genealogies taking it outside Europe' (Asad 2003, 14), thereby resisting the idea that modernisation means secularization which in turn means Westernisation (Aysha 2006). Thus, instead of reading the Iranian Revolution as Islamist fundamentalism that only manages to suppress women and homosexuals, among others, it could be read as a populist political movement that incorporates aspirations of becoming part of the modern world, but on one's own terms (Aysha 2006, 390-391). For an ethnographer, such populist desires provide interesting momentums that help focus analysis on issues of lived, embodied, gendered everydays that contest any simplistic readings of how norms may be lived and enacted by drawing attention to aspects of ambivalence and ethical self-cultivation (Fadil and Fernando 2015, 67; Schielke 2015; Rao 2020, 30, quoting Mahmood 2005, 23).

Thus, aligning with Babak Rahimi's review of Afary and Anderson's book (Rahimi 2006), I would support the argument that its chief value lies in the epilogue that briefly touches on the ways in which Iranian thinkers since the revolution have both critiqued and used Foucault's thought; for example, his work on knowledge/power and critique of European modernity is used, 
in its turn, to critique Iranian Islamist doctrine taught in schools and colleges, thereby making resistance not only political, but also social and cultural (Afary and Anderson 2005, 174). What I find to be one of the most valuable attempts to read Foucault's ideas on 'political spirituality' is that of Mahmoud Khatami $(2003,121)$, who notes that 'he argues for the prioritisation of the body and sexuality to embody belief in order to bring up the micropolitics of religious utterances and silence, and to develop a technology for the religious government of the self'. Khatami also makes the argument that by using Iran in an occidental way, Foucault is critiquing the West for its divisions between the spiritual and material, and religion and politics.

At this point, it is important to return to the criticism that Mahmood has received for Politics of Piety, and her responses to them, in order to show how, at this particular moment in time, feminism and feminist critique are being readily classified and dismissed as liberal, secular, Western and/or culturally relativist, with the effect that only specific forms of being a Muslim become visible (Deep 2015, 95). This is a notion that my earlier work on the politics of post-tsunami reconstruction in Aceh challenged (Jauhola 2013) by calling for a queer feminism that is attentive to tendencies to totalise discourses, the formation of new forms of violence and vulnerability, and the possibilities that constant renegotiation, or even rendering resistance invisible, can offer.

Taking this observation back to the discussion on agency and resistance, Mahmood urges us to pay close attention to 'those registers of corporeality that often escape the logic of representation and symbolic articulation' (Mahmood 2012 [2005], 188). It is the positive affective experience that lies at the centre of Mahmood's analysis (Ibrahimhakkioglu 2012, 17). Thus, bringing the debates on agency together finally leads me to suggest the following: Mahmood and Khatami both seem to be suggesting that an analytical focus on embodied practices of self-making is important, as Foucault has remarked:

Are there no great radical ruptures, massive binary divisions, then? Occasionally, yes. But more often one is dealing with mobile and transitory points of resistance, producing cleavages in a society that shift about, fracturing unities and effective regroupings, furrowing across individuals themselves, cutting them up and remolding them, marking off irreducible regions in them, in their bodies and minds.

Foucault 1998 [1976] [1978], 96

Further, the governing of sex was not so much developed to control and discipline abnormalities as to affirm the bourgeois self:

The primary concern was not repression of the sex of the classes to be exploited, but rather the body, vigor, longevity, progeniture, and descent of the classes that 'ruled'. This was the purpose for which the deployment of sexuality was first established, as a new distribution of pleasures, 
discourses, truths, and powers; it has to be seen as the self-affirmation of one class rather than the enslavement of another: a defense, a protection, a strengthening, and an exaltation that were eventually extended to others - at the cost of different transformations - as a means of social control and political subjugation. With this investment of its own sex by a technology of power and knowledge which it had itself invented, the bourgeoisie underscored the high political price of its body, sensations, and pleasures, its well-being and survival.

Foucault 1998 [1976] [1978], 123

Rahimi's reading of Foucault's writings on Iran, however, rather focus on his rejection of writing the history of the future (Rahimi 2006). In Foucault's words: 'I would like to grasp what is happening right now, because these days nothing is finished, and the dice are still being rolled' (Afary and Anderson 2005,220 , emphasis in the original). Thus, rather than seeing Foucault's writings as a failure to evaluate the real effects of the Iranian Revolution, and as taking the anti-feminist stance of being too optimistic about its possibilities, Rahimi suggests that instead of seeing the revolution as a 'teleological process that would (or should) eventually lead to a democratic or an autocratic outcome ... [Foucault] was more fundamentally concerned about the phenomenon of revolution in terms of the aesthetics of action ... that is free from constraint of power, and liberated into an open world of possibilities without a determined end' (Rahimi 2006, para. 18).

This reading of the role of a researcher aligns with a methodological focus on the 'here-and-now', which I have described as an ethical approach to ethnographic encounters (Jauhola 2015a) consisting of both acknowledgment of the embodied presence of the ethnographer self and the co-constituted nature of knowledge production, to be discussed in the next section.

Thus, another reading of Mahmood's ethnography is as a discussion of how the da'wa movement has successfully provided new capabilities for middleclass pious subjects to emerge, which, in the context of Egyptian gender and its religious knowledge/power nexus, can be seen as a form of radical transgression against an authoritarian and violent regime or Western influence, but also as a form of cultivating agency on its own terms (Mahmood 2012[2005], referenced in Kandiyoti 2009, 94; see also Rao 2020). This further leads to an ethical question about the capabilities and agency of those who potentially fail to fulfil the expectations, doctrines or even laws poised by the da'wa movement as its ideals, which should not necessarily be read as counter-conduct or acts of resistance as such, but, rather, as forms of living beside one another, as the lived realities from Banda Aceh suggest.

\subsection{Methods for Decolonisation / Reversal of Research Praxis}

Dipesh Chakrabarty has suggested that '[p] ostcolonial studies seem to have been a part, initially at least, of a cultural and critical process by which a 
postimperial West adjusted itself to a long process of decolonialisation that perhaps is not over yet' (Chakrabarty 2012,2). Thus, to assume that ethnographic scholarship has completed its post-colonial critique, or concrete decolonialisation process, is a false and too hasty conclusion to be made. Turning to specific demands that research methodologies be decolonised, Linda Tuhiwai Smith has argued that: 'from the vantage point of the colonized, the term "research" is inextricably linked to European imperialism and colonialism' (Tuhiwai Smith 2008 [1999], 1). Tuhiwa Smith illustrates, with examples, how research is a 'dirty word': it causes silence, brings back bad memories and 'raises a smile that is knowing and distrustful' (ibid.). The main aim of Tuhiwa Smith's book is to provide a wide research framework, called 'researching back' (Tuhiwai Smith 2008 [1999], 7); this I relate to other methodological tools of writing and talking back to the powerful through the oppositional gaze (hooks 2003) that challenges and resists intended 'meanings through complex negotiations between viewers, producers, texts and contexts' (Jauhola 2013, 28-29). These include questions such as: 'Whose research is it? Who owns it? Whose interests does it serve? Who will benefit from it? Who has designed its questions and framed its scope? Who will carry it out? Who will write it up? How will its results be disseminated?' (Tuhiwai Smith 2008 [1999], 10).

This intimately relates to issues of division of labour, authorship and continuity in the operation of social power. Raewyn Connell specifically refers to this power as the 'appropriation of knowledge and marginalisation of other knowledge systems' (Connell 2016). A recent review of the emergence of studies on climate change, HIV-AIDS and gender studies (Connell et al. 2017a) pointed to three mechanisms through which the dominance of the Global North was instituted: resource inequalities, workforce mechanisms and intellectual framing. These mechanisms work at the level of structures and institutions, but also relate to material inequalities, such as research funding and careers. Sandra Harding (2008) suggests that even well-meaning research endeavours, both in the Global North and Global South, 'are doomed to fail when they do not critically engage with spectres of [European] modernity' (Harding 2008, 2).

Recognition that colonising practices are not just limited to that of exchanges between the Global North and Global South draws on observations by Chakravorty Spivak, according to whom a new transnational elite class structure cuts across the globe, across race and the North-South divide by virtue of the 'metropolitan education' which produces a common language that overpowers subaltern voices (Spivak 2008, 16-18). The project of deconstructing such social power mechanisms could learn from the Freirean idea of enforcing cooperation between illiterate students and professional specialists in defining school curricula: 'Such work has, always, a local reality in the lives of people who are perfectly able to describe what they do' (Connell et al. 2017a, 24). As a research practice, this would then actively reconstruct the subjecthood of the researched (Sabaratnam 2017) as co-analysts of their realities.

How does one co-create research? Nasir Uddin writes of the absolute authority of the ethnographer in writing text (Uddin 2011, 462). He acknowledges 
that scholars are, increasingly, practising empathy with the people they study, and are more aware of the power relations that are embedded in academic knowledge production (ibid., 459). Yet, instead of arguing for the production of new theories to resolve the situation, he argues for

... more engagement and reengagement with the field and with the people rebinding the ties of mutual trust between research and the people, making adequate space for local narratives in the text to justify ethnographer's analysis and narrowing down the absolute authority of ethnographer for writing about 'another culture', social research methodology in general and ethnography in particular can be decolonised.

Ibid., 463

Along similar lines, Tiffany Page has suggested a turn towards vulnerable writing which acknowledges that 'unsettled uncertainty of the research process, rather than foreclosing on further understandings, provides space for new forms of unknowing and continued attempts at understanding the stories of others' (Page 2017, 28).

The vulnerability could explicitly address, as Tiina Seppälä (2016) points out - referencing works of Casas-Cortés, María Isabel, Michal Osterweil and Dana E. Powell (2008), Maria Lugones (2010), and Eve Tuck and Wayne K. Yang (2012) - the basis of the naturalised 'right' to conduct research in the Global South, something that social movements such as women's groups and indigenous communities have sufficiently - and constantly - questioned and challenged. The continuing reluctance to address this critique sufficiently is a result of the academic tendency to distance knowledge production from the people, to theorise without localisation and histories, resulting in offering very little for actual struggles or strategies to be employed in the everyday lives of the people concerned (Seppälä 2016, 16; Sabaratnam 2017, 29-32). As a response, or as an alternative, Seppälä suggests developing 'decolonial feminist solidarity' that is centred around the recognition of potential tensions and contradictions in (feminist) action, drawing attention to voicing feminisms that exist outside the dominant middle-classness and whiteness (Seppälä 2016, 40), as Uddin (2011) has also suggested.

Yet, attempts to focus on situated knowledge production has led to highly criticised confessional modes of self-reflexivity which, according to Tilche and Simpson, have Eurocentric roots in Christianism, class privilege and the rise of neoliberal audit cultures of self-accountability and governance (Tilche and Simpson 2017, 2). One significant consequence of the demand for reflexivity in authorship is a move towards collaboration and the co-production of research (ibid., see also in film production in Harman 2019). However, assuming that collaboration or co-creation can operate outside of power dynamics would be short-sighted, as Sara Ahmed (2000) has warned the white scholars. Any attempt to engage with the politics of race, or coloniality, requires a return 
to basic questions: what does ethnographic knowledge production consist of? What does it aim to do and on whose terms? Jayasankar and Monteiro (2016) describe these questions as an essential part of 'subaltern practice' in documentary film production. Such questions demand analysis of the relationship between the film-maker and 'the subjects', of the politics of knowledge production and the authorship process, and acknowledgement of subaltern knowledge that questions the promise, and the premise, of the documentary in the making (Jayasankar and Monteiro 2016, 222-226, e-book version). Furthermore, Sarah Pink has suggested that

... visual ethnography ... does not produce an objective or truthful account of reality, but should aim to offer versions of ethnographers' experiences of reality that are as loyal as possible to the context, the embodied, sensory and affective experiences, and negotiations and intersubjectivities through which the knowledge was produced.

Pink 2013, 35

I read the above as suggesting that the knowledge- and meaning-making production is in fact open, although many formats such as articles, monographs and films as forms of communication suggest otherwise, and moving the debate out of the reach of most of those researched. Understanding the research process and the meaning-making as open implies studying connectedness, and locating ethics and responsibility in 'our receptivity to others ... the voices to which we listen and the experiences we account for - and in how we craft our explanations: whether our analytics remain attuned to the intricacy, openness, and unpredictability of individual and collective lives' (Biehl and Locke 2010, 318).

Pushing research dissemination towards the use of digital media requires more fundamental and wider considerations of justice than opening access to scientific publications (Nobes 2017). It means, among other things, a critical reflection of the use of digital tools that are still dominated by the production processes of the Global North, where the 'other' is either rendered invisible or tokenised. Maha Bali further suggests the requirement of listening to diverse voices speaking on their own terms, which necessitates the use of culturally relevant pedagogies and careful reflection on what is meant by inclusion at decision-making tables. She asks how and who designs the decision-making table, where it is placed, what rules are applied during decision-making and whether process participants can make safe departures from the collaboration, if they wish to do so (Bali 2017a, 2017b).

In the final section of this chapter, I reflect on and critically read the ethnographic research, publishing and dissemination strategies, and the production process that became part of this research - stumbling scholarship, as I will call it. Along with describing and reconstructing (in retrospect) my research process and its contradictions, the exegesis represents an attempt to locate desires, resistance to knowledge production and places where the mere feelings of 
cosiness or intimacy were in fact structures and praxis where white privilege and saviour/noble savage tropes were manifested.

\subsection{From Street Ethnography to Film Production, and Visual Representations}

This section reconstructs retrospectively 'stumbling scholarship' leading to writing up/editing this research, that is, the research process that has expanded over eight years between 2010 and 2018, and which included the first initial ethnographic visits (2012-2013) during which I began to envision methodologies for multi-sited urban ethnography, the short-film production process (2015-2017), and various attempts to develop innovative research dissemination and knowledge production forums such as web-based articles and blogs, film screenings, talks and events (2018-2019) (see, e.g., Donaghey and Jauhola 2017). As the following narration is organised in a temporal, linear fashion and thus may confuse the reader with patterns of planning and consciousness which may have not been there at the time, I wish to emphasise how the actual 'stumbling over' is in fact more of a spiral, coincidental affective trajectory, and at times driven by crises or outside triggers.

\subsubsection{Multi-Sited Ethnography (2012-2016)}

All in all, between 2012 and 2016, I spent in total 7.5 months in Aceh, but the seven-year period has included daily data collection using social networks and online media sites. This has amounted to thousands of screen captures, hundreds of pages of field notes and hundreds of electronic copies of news items.

I initially anchored the urban ethnographic data collection in the city of Banda Aceh around the riverbank of Krueng Aceh that cuts through the centre of the town and hosts Chinatown, the main mosque Baiturrahman, the public park of Taman Sari, the Tsunami Museum and the town's governmental offices (Image 2). Yet, ethnographic encounters and life history stories told by street vendors, punks, hip hoppers, ex-combatants and their (ex-)spouses, members of Christian and ethnic Chinese minorities, and local LBGTI activists introduced me to everyday lives that are spread and connected across the city, the province, the Indonesian archipelago, the Malacca Strait region and the rest of the world.

In my first methodological piece, a chapter written for the edited book Emotions, Politics and War (Jauhola 2015a), I promoted the method of 'here and now' as an active stand against 'mindlessness', that is, conducting research as though in automatic pilot function, and using preconceived beliefs, categories and frames (Penttinen 2013, 37). I suggested that the focus on here and now is a call to understand concepts as accomplishments at the end of an investigation, 


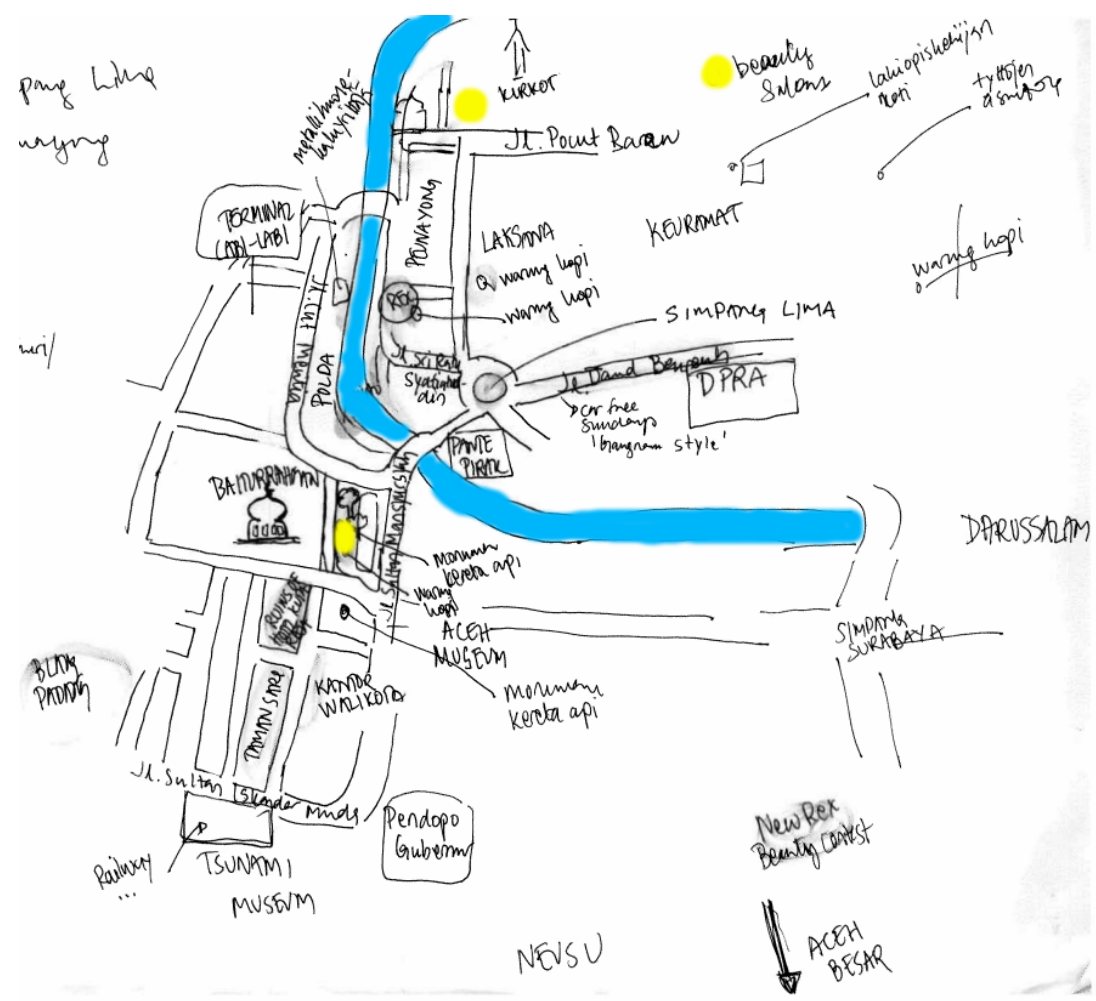

Image 2: Map of Banda Aceh.

Source: Drawing by Marjaana Jauhola.

rather than allowing them to guide it, with the aim of envisaging alter-native worlds and political imaginaries (Shapiro 2013, xii, xiv). Thus, instead of encouraging the production of the researcher's 'me-self' through navel-gazing reflexivity and confessions of potential positionalities, this approach focuses on experiencing states of temporal becoming through intersubjectivity and relational forms of being that are not restricted to physical bodies, but comprise connectedness to, and resonance ${ }^{11}$ with, bodies, materiality, space and how the body and its affects move within that space (see also Oikarinen-Jabai 2017).

What does this mean in concrete terms? Instead of identifying and verbalising the researcher's encounter with the researched as always already dichotomous and hierarchical, I draw on a body of literature that understands such research encounters as active processes of becoming, of being touched and moved (Puumala 2013, 126). Gender, for example, is a process of becoming, relationally, rather than a state of being of a sovereign, gender-specific, embodied subject (Skeggs 1999, 42). Mindful research practice thus deconstructs the 
constructed illusions of a researcher's subjectivity that is a whole, autonomous and sovereign entity (see, e.g., Jackson 2007).

Eeva Puumala explores 'exposure', or 'being exposed', as a method as well as an analytical approach to the governmental practices of migration policies. Being exposed as an ethnographical research method requires a perceptive focus on presence in the here and now, and on being through shared encounters; it activates the connectedness of the self with a sense of the temporality and spatiality of politics, generating an understanding of political communities as experiential and touching, whereby bodies are open and in flux and formed through corporeal conjunctures (Puumala 2013, 125-126). To Puumala, this creates a tension between politics and acts that ontologically insist on sovereign subjectivity, on the one hand, and distinctions between self/other and inside/outside on the other (ibid., 127-128). Adding to this, Hanna Väätäinen $(2003,2009)$ proposes an ethnographic methodology that connects affects to engaged and embodied practice: ethnographic orientation that is aligned with changes and transformation. This approach accepts that while ethnographic improvisation requires both careful planning and preparedness, it can be combined with the ability to discard those plans, a willingness to let go. Improvisation does not mean acting without any frames or boundaries, but, rather, accepting their permeability of frames and boundaries, and the impossibility of foretelling what will happen next (Väätäinen 2009, 43). This requires openness to intuition and immediate experience which, according to Elizabeth Grosz $(2005,136)$, allows us to get closer to the movement, resonation and transformation that resides outside of all the senses; intuition is creativity, the ability to see and do things that elude everyday need or use-value.

However, understanding ethnographic encounters as taking shape in the here and now does not imply endless vistas of possibility and freedom opening in all directions. Rather, it evokes studying a form of connectedness consisting of dimensions of ethics and responsibility relating to 'our receptivity to others ... the voices to which we listen and the experiences we account for - and in how we craft our explanations: whether our analytics remain attuned to the intricacy, openness, and unpredictability of individual and collective lives' (Biehl and Locke 2010, 318). The task for the researcher is to problematise conceptualisations that insist on sovereign subjectivity and its independence, and to recognise that the researcher's body, and thus also the authorship of the research, is connected to unseen forces and flows (Väätäinen 2009, 47).

What does a mindful researcher do during ethnographic encounters? Firstly, as discussed in detail in Chapter 6, 'Queer Community and Care', paradoxes of visibility of coming out - allowing new kinds of liberal rights demands, but also causing new vulnerabilities - require methodological and ethical attention. The consequences of the passing of the Islamic Criminal Law (Qanun Jinayat), together with the politicisation of anti-LGBTI stands in Aceh and more widely in Indonesia, are discussed from the perspective of both ethical research concerns and do-no-harm principles, initiated in humanitarian aid environments 
(Anderson 1999) and discussed within recent queer ethnographies (Gray 2009; Engebretsen 2014). Yet, as I discuss in the chapter, drawing on the idea of messy ethics, and ethics as lived and hermeneutic rather than as comprising neutral lists and procedures, I remain cautious of advancing the concept if the underlying assumption is that it is possible to reach a stable situation of 'no harm'. As my research over the last decade in Aceh has shown, positions of being harmed or harming others involve complex, dynamic and constantly changing orientations towards others, and oneself.

Secondly, who has agency in defining processes as harmful or safe and what conclusions can one draw from these experiences in terms of shifting and changing contexts? My feelings of awkwardness, fear and disorientation, and the sense that ethnography is by no means smooth, have been important points where potentially harmful situations have materialised into affects and the necessity to engage with the politics of the white female body. Living through such moments has also shown me how a sense of belonging to the queer and the punk communities is constructed in Aceh (Thajib 2015). On many occasions, the researcher is left with silence and disappointment, as will be further explored in the following section. Yet, instead of reading such occasions as a story of victimisation and oppression of queers or punks, or as a failure of research, those seem to be decisive moments for a transman like Raiz, or the Sufi healer, to set limits on what can become knowable and shareable, thereby making lives, primarily his and his loved ones, bearable and tolerable (Jauhola 2017).

Thirdly, approaching the here and now has also included facing the 'phenomenology of whiteness', by which Sara Ahmed means 'an effect of racialisation which shapes and orients how bodies take up space and what bodies can do' (Ahmed 2007, 150); she also calls this the 'background to experience' (ibid.). Thus, to her, it is 'a reminder of the histories of colonialism ... which makes the world "white". A world that is inherited, or which is already given before the point of an individual's arrival' (ibid., 153). Yet, embodying whiteness in ethnographic research is far from being simple, nor does reflecting on it necessarily involve navel-gazing or attempts to delete the white body from ethnographic encounters, as will be discussed in relation to video production and editing in the next section of this chapter. It does mean, however, becoming more aware of the expectations that one's presence creates and also the spaces we occupy and what they enable and disable. To be avoided is the course of remaining stuck monolithically on whiteness itself, rather seeing it as a relational positionality with regard to questions of social class, gender and sexuality (Griffiths 2016).

Fourthly, during this ethnographic research, my embodied self was, in fact, in a flux. I learned about the expectations I had developed in neoliberal academia and knowledge capitalism (Brunila and Hannukainen 2017) of producing quick results, in terms of knowledge and analysis, and also how difficult it was to let go and unlearn such inbuilt expectations, but also how exploring 
unconventional forms of research publications in art museums and exhibitions enabled me to see how differently those shook the power dynamics and regimes of truth established in Finland regarding the 'success' of the peace process.

Thus, by research ethics I do not refer (only) to research protocols or to clearing research proposals with ethics committees, or a separate objectified domain of theory, but understand it as what Lambek and colleagues (Lambek et al. 2015, preface, para. 6) have called 'a part of life as it is lived with others, worked out in interaction and conversation with others rather than transcendent of them, and within a given historical, cultural, and social context', and what Michael Lambek further describes as a hermeneutical process:

[A]n anthropological approach [to ethics] requires an appreciation of the kinds of worlds in which people do live, as established through ... culture, social structure, ontology, cosmology, world view, religion, the state, biopolitics, et cetera, but here understood not as static structures (as they too often have been) but as dynamic orientations for acting in the world ...

Lambek 2015, para. 15

All these explorations of what ethnography comprises provided anchors for discussions and means to enter into dialogue on how we react to changes that happen around and within us that are simultaneously intimate and also function at the level of elite populist politics. Ethnography is the embodied form of situating oneself into spaces, while film documentarism prioritises visual and audio at the expense of textual. I suggest that stumbling scholarship can be a process and a longer-term commitment to encounters of care, whether face-to-face, or be it when reproducing visual, written or verbal accounts of those encounters and stories, and their analysis. Yet, it is tiring and exhausting, as most of the phases, such as the production of a short documentary film, are both internally and externally questioned: What is it that this is for? What do you aim to get from this? When is the film ready and when can I see it? What will happen to it? When is the research over?

Such questioning offers important anchor points where the research practice is being tested and negotiated. It slows down the pace, even jams forward movement. It sometimes results in appreciating private knowledge production for the marginalised community, at the expense of academic productivity in public. Yet, it is the only way I feel that I can remain truthful to the idea that the moment something becomes easy, one needs to become alert to the potential exploitation and misuse of power (paraphrasing Spivak, quoted in Landry and MacLean 1996, 293).

\subsubsection{On Documentary Video Production}

The push towards visual storytelling and research representation in this research was led by the research collaborators (2012-2014). Ultimately, it 
was the latest visual advances of smartphones that sneaked into my research with the help of the street punk community: taking photos and making short videos with a mobile phone, discussing certain online and offline photo archives with research participants, and experimenting with auto-photography as part of life history narration, and visualising the everyday of urban ethnography. During the later stages of the ethnographic fieldwork in 2015-2016, a shortfilm documentary project in 2015-2016 with digital designer and documentarist Seija Hirstiö was incorporated into the overall research design. The title was 'On the edge of documentary film and guerrilla research: ${ }^{12}$ challenges of realising indiscrimination and equality in the peace process in Aceh. The aim was to push the previously fairly low-profile ethnographic research towards a more critical, and vocal, analysis of the aftermaths of the Finnish-mediated peace process. We teased out the dramaturgic premise, or the essence, of the production to focus on the following:

\section{A decade into the post-tsunami and post-conflict reconstruction and 'building Banda Aceh back better', people in the city have continued expe- riences of vulnerability and varying forms of violence.}

In order to cope, they have to make radical changes in their lives.

The final push towards audiovisual methodologies was prompted by a critical reflection on academic publishing behind paywalls, and uses of language and media that do not speak to non-academics or non-experts. Despite being aware of the potential 'epistemic violence' (Spivak 1988, discussed in detail in Vastapuu 2018) in ostensibly speaking for all Acehnese, after I established a dialogue with an older ex-combatant, the 'main character' of three videos (see also Chapter 4), I felt that such a method of writing/speaking back, using mixed dissemination methods, was the most appropriate one. I felt that his analysis of the realities of peace, and his demands that they should be narrated back in Finland, and later in Aceh, were pushing me to evaluate critically how and where, and by whom, the research findings should be discussed: With whom should I, primarily, negotiate the research with? Who are, or should be, the true peer-reviewers of my research?

This phase enabled the narration, in an audiovisual format, of selected life histories through the frame of the politics of reconstruction and the making of the peace - a process that Meera Sabaratnam calls the 'reconstruction of subjecthood' (Sabaratnam 2017, 39). Here, I draw from the works of the new materialist documentarism, which explores the possibilities, and difficulties, of collective ethnography and film-making, and examines questions of authorship and research as the open-ended, co-creation of worlds (Coppens 2012, 2013; Hongisto 2015).

However, the arrival of smartphones with cameras and increasing numbers of self-produced videos in social media happened at the same time as a growth in reality TV formats using unpaid participants, and mediated selfperformances and genres in which the participants are characterised as 'failing' 
and in need of transformation ${ }^{13}$ (Skeggs and Wood 2012, 3). This raises new questions for media analysts working on the politics of representation, not only in terms of reality TV programmes, but also in terms of how the new forms of documentarism and visual ethnography, and the actual process of producing them, may potentially be perceived both by the viewers and those researched/filmed. The different contexts within which the documentary films are screened or distributed, and the genres they potentially resemble, establish how different 'audiences cognitively "read", "make meaning" and "interpret" media texts' (ibid., 5). Thus, the idea that one should remain 'cautious of the self and its association with a singular subject, changing it to the idea of personhood as the project progressed' (ibid., 4) is an important one to consider.

Yet, throughout this process (production, post-production and dissemination), there are obvious limitations of the approach as regards democratising research praxis, in particular vis-à-vis authorship and ownership. This caveat has remained, despite the fact that questions of consent and processes of decision-making in relation to the video production, the writing of chapters and decisions on how to disseminate and use these products have been communicated, negotiated and discussed over a long period of time with those involved in the process. The benefits brought by new digital technologies and the use of social media to ethnographic encounters thus remain debatable. At times, resisting colonial academic knowledge production practices, and familiar colonial representations, and imagining alternative worlds and political imaginaries, requires juxtapositions and exhibiting the white gaze. Sometimes it also entails the realisation that ethical research encounters require the film production to have other more useful purposes for those who participated, such as a vehicle to gain access to governmental support services, or purely ease the burden, rather than just one more video for the consumption of the global 'free public sphere'.

\subsubsection{Teasing Out a Coherent Story}

Without conflict, you have no action; without action, you have no character; without character, you have no story; and without story, you have no screenplay.

Field 2005 [1979], 25

Having entered the world of documentary films, one of the first contradictions was to relate the ethnographic life-historical data with that of the mode of script writing and casting. Casting, as it is understood in the performing arts, is the selection of the main character or players, and their story, for a role in the pre-production phase. Although ethnographic praxis might seem to differ from other forms of film-making, and the research process is not so selective, ultimately it also involves similar choices, inclusions and exclusions. It is just 
that they are not canonically stated as bluntly for readers of academic articles as by the framing and editing of the film. In documentary films, the ethnographer makes choices about whose lives and which streets and stories to attend to, and to document (as written notes, photographs, collected items and so on) and analyse. As film was introduced to the research methodology in the later stages of this project, the film-maker was brought in only when the 'casting' was already completed during my three research visits to Aceh between 2012 and 2014. In fact, it was my first article (Jauhola 2015b) narrating several life histories which clearly provided the first rough overall script for the videos and their casting. It approached the complexities of rebuilding the post-disaster city through seven life-historical accounts of experiences of home and belonging. It was with the help of these synopses that we started the pre-recording script-writing process in Finland.

Yet, on-site life-historical video production with limited available camera time had a totally different structure and daily presence in the city from that offered by the improvisation, namely, spontaneous ethnographic explorations of the city and hanging around as a single researcher. It required logistics, such as the use of a car, and pre-planning to ensure that the seven short stories, and general footage, could be accomplished on a limited time schedule. Additional crew were recruited to support the production: the poet Zubaidah Djohar, whose poems were turned into videos, was called in to conduct interviews and translations from Acehnese to Indonesian. She later visited all the main characters to go through a detailed screening, feedback and reflection process before the videos were formally released, with her poems, for online viewing in 2018. Two other members of the Acehnese scholarly community also took part. ICAIOS librarian, Evi Susianti, went through over 10 hours of recordings and provided Indonesian transliterations, while MSc Mifta Sugesty provided English subtitle translations for the edited life-historical videos. Their contribution was also crucial in discussions of the topic sensitivities in the videos and in making decisions about how to protect the material from outsiders. The nature of the process also meant that my role as a researcher was augmented by others.

The documentarist's primary focus on the aesthetics and visuals allowed me to reflect critically on the other framings that I as a researcher considered normal: the academic vocabularies and traditional notions that ethnographic film reproduced the truth, even though I had theoretically been debating the impossibility of such truths in the first place. The dissemination process taught us that the documentarist does not have an absolute control over what she films (Hongisto 2015, 13). For example, my research started moving in unanticipated visual directions, and allowing further recognition that there is no possibility for full representation of the 'peace in Aceh', but rather, that our work could at best 'claim a territory in the dialectical relationship of the reality being filmed and filmmaking - negotiation gives rise to a performative documentary truth' (ibid., 15). 
The script writing before the film-making visit to Aceh in December 2015 to January 2016 imagined the life histories and recording sets a priori. Thus, we were actively creating documentary truth, not to replace the previous constructions, but rather on top of it, or beside it. With some of the main characters, it was possible to use social networking applications (such as WhatsApp) to plan for the scripts and recording sets beforehand, discuss possible themes to be covered and also agree on recording/shooting locations. Early in the process, we decided to aim for around five-minute-long documentaries, which would be independent, but connected, so that structurally they could be screened and watched independently, but that as a full set, they would amount a feature-film length.

From the seven life histories recorded in December 2015, two types of processes emerged: one which I call 'film activism', and the other 'negotiated co-composing', of which I will provide examples in the following. The video, Coaching to be strong transman, gained its name from the shooting location that was chosen for the first scene of the video: a park gym. The initial discussions of the script were initiated using WhatsApp (see the detailed discussion in Chapter 6). We soon realised, however, that the story could not be filmed safely in Banda Aceh, as two white women with cameras would pose too much of a risk for the main character's safety. During the recording visit in Aceh, we met just once ${ }^{14}$ to agree on the recording themes and logistics. While recording, we would merely prepare the setting and operate both camera and audio recording, and the transman would describe what the focus of the recording set would be about, expressing his idea of the documentary truth. We took just one shot from each set, which we used and edited for the final version of the video. It felt like we were facilitating a storytelling process by suggesting and considering suitable shooting locations, but the contents and precise lines in each set were developed and controlled by the main character himself. The editing phase in Finland also provided the possibility of showing the layered WhatsApp chats we had had during both pre- and post-recording. Those were included with the aim of illustrating the precariousness of everyday life, and how the solutions to such situations unfolded.

I call the other life histories 'negotiated co-compositions', in which the involvement of the main character varied from active planning, to being an interviewee in front of the camera, and guidance according to responses to questions such as: 'What of your life would you wish us to cover?' On these occasions, the role of the camera person or the audio recorder recreated classic ethnographic images of the white gaze (Jauhola and Bolong 2017), such as those of Margaret Mead in Bali with her Balinese translator/research assistant.

In some cases, however, such as in Solving nikah siri - unregistered marriage, the script was totally redeveloped after the first meeting in Banda Aceh. The decision was made to follow the unfolding of a situation wherein the main character suspects her husband of remarrying without her consent. During the post-production period in Finland, we further decided to leave my role as a facilitator visible (I had contacts with the municipal for women's empowerment 
and legal counselling) and actively allow the viewer to represent the reproduction of the 'white saviour' trope.

We intentionally kept the production team, equipment and 'break of drama' moments visible in the final cuts, which was our way to illustrate the constructedness of the process, including reproduction of the white gaze or white saviour tropes. Often, such situatedness or positionality is hidden during the editing process, using cuts and transfers, and replacing the soundtrack of the interviewer with other sound/audio recordings. The possibility of deconstructing the final edited videos back to clips also allows us to illustrate how the knowledge production and naturalised narrative structures of a completed video are in fact replaceable and questionable, and the order of clips flexible. As the final versions have gone through a feedback and approval process with the each of the researched main characters, there are further recording archives that will not be made available to the wider public, for reasons connected to consent and anonymity. The plan is, however, that the transcripts of the recordings could later be returned to Aceh, allowing the Acehnese to access such narratives.

Two purely journalistic-styled interview videos were also produced. As mentioned in the Introduction, in November 2015, just a month before our recordings in Aceh, two Acehnese women participated in a Helsinki event (partly supported by our short documentary funding) to reflect on the 10 years of peace in Aceh, and a recording session at the site of the signing of the peace agreement was arranged for them. This was historical, as none of the women activists or scholars had ever visited the site, nor had they been formally recorded in Finland reflecting on the gendered politics of peace in Finland.

Titled MoU Helsinki: reclaiming back history, it can be read as the joint reclaiming and 'talking back' moment of three differentially situated and positioned women: Professor Eka Srimulyani from the Islamic State University Ar-Raniry, Donna Swita from the Women's Solidarity for Human Rights/ Solidaritas Perempuan, and me as a researcher from the University of Helsinki and an active member of the Finnish civil society / scholarly network on UN Security Council Resolution 1325. Similarly, during the recordings in Banda Aceh, through our Acehnese connections to the Sharia Department we were allowed to record a video which focused on an interview with the head of the Department of Shari'a Islam, Professor Syahrizal Abbas. Combined with other recordings and local TV clips, the video, Shari'a and visions for peace: blueprint for just and equal Islamic law, illustrates some of the ideological variations in the ways in which Islam, and the implementation of Sharia law, are currently envisioned in Aceh.

Finally, documentarist reality filming and so-called guerrilla research tactics included the development of a website ${ }^{15}$ and a Facebook page, ${ }^{16}$ the latter of which was actively used as a publishing platform for daily video entries during the recordings in Aceh, along with advertising events, talks and screenings. Up until early 2018, due to consent and security concerns, posts did not reveal 
the individuals involved in the production, but rather played with the everyday incidents and curiosities we came across while recording, describing the themes of the videos using unrecognisable stills and direct quotes.

Yet, there is a more fundamental question concerning scripts and screen writing that deserves further interrogation. Dominant theories of screen writing or script writing are Eurocentric. Consequently, critical media studies have followed forms of 'visual sovereignty' (Raheja 2007) - that is, reconfiguring ethnographic documentarist film-making from indigenous people's perspectives. In that format, the process from inception to release is slower and caters to different interests from those addressed by dominant documentary films; potentially, such film-making also seeks alternative venues to, say, film festivals, for its dissemination. Practising visual sovereignty, from the perspective of this production, resonates with principles outlined by Michelle Raheja: members attempt to reach consensus on the details of the film; the director or producer is a facilitator, or a contact person, rather than solely in charge of making final decisions; and versions are screened before an audience and edited according to feedback. Usually, the film-makers continue their relationship with the film's content and its multiple spectators long after the cameras stop rolling (ibid., 1166-1167).

Over the years, all in all roughly 20 to 25 screenings have been organised in the Global North: at academic conferences, lectures or seminars, and as nonstop TV screenings at campuses and public libraries, in a pop-up space at a busy pedestrian shopping street and as screening events at two schools in Vantaa, the town that hosted the peace negotiation rounds in 2005. Furthermore, the videos became part of the 4.5-month-long art exhibition 'PAX - Let's Speak of Peace' at the Vantaa Art Museum Artsi in 2018:

The theme of the new exhibition at the Arts Museum in Vantaa is peace, one of the most used euphemisms in our history. During the last century, peace has justified war, colonialism, genocide, exploitation and oppression.

Vantaan taidemuseo ARTSI n.d.

Following this re-politicisation of the concept of peace, the blurb of the exhibition invited the museum visitors to revisit the politics of using the Aceh peace process as part of the Finnish peace mediation branding, and the representations of the peace process as a success:

Media constructs us a contradictory picture of Aceh either as a fully successful peace process and flagship of Finnish peace mediation, or sphere of ultra conservative forces. How do the everyday lives look in the shadow of Finnish peace mediation and nation branding, after the Indian Ocean earthquake and the tsunami, and over thirty years of armed conflict? 
What is the price of peace?

Vantaan taidemuseo ARTSI n.d

Simultaneous to the exhibition for the Finnish audience, a screening tour was organised at three locations in Aceh focusing on conflict-affected women (both combatant and non-combatant) and female university students. Selected videos (From ex-combatant to Sufi healer 1-3, Videos 9, 10 and 11) were screened jointly with Zubaidah Djohar's selected poems from the collection 'Building a boat in paradise' (Djohar 2015). The dialogue was aimed at reflecting on gendered recovery strategies and stories deriving from the survivors of conflict and the tsunami: experiences of self-reliance, managing disappointments and recognising one's potential, while attempting to make lives better in the midst of economic and social difficulties. The feedback and reflections of these events is discussed in Chapter 4. The event organised at the University of Malikussaleh campus, where I had visited in 2012, further led to a student-initiated creative writing process (link to peace generations video) and in 2019 the launch of an edited volume Dalam keriput yang tak usang: suara pemuda dan jalan panjang perdamaian Aceh (Wrinkles that remind of the past: voice of youth and the long journey of peace in Aceh) (Djohar 2019). Another spin off book, is the 2020 published Bisu yang Bersuara (Silent gaining voice)(Djohar 2020), which includes all in all 47 poems and short texts written by Acehnese survivors of violence, which was initiated in a creative writing workshop held in Lhokseumawe, and came to existence with the voluntary mentoring and editing efforts by Zubaidah Djohar, and published as a joint book by Acehnese women's organization Relawan Perempuan untuk Kemanusiaan (RPuK) with the funding from The Asia Foundation and Australian High Commision in Indonesia. All in all, the research process has taught lessons on sensitising one's analytic skills to articulations of power, but also on how the power manifests itself through articulations of peace, which rely heavily on hegemonic and militaristic masculinity, and form an elite-driven 'peace industry' (Lee-Koo 2012; Abdulah 2018, 106; Lee-Koo 2018).

\subsection{Beyond Fables and Peace Brands}

This chapter has discussed the urgency of the postcolonial critique of academic knowledge praxis - ways in which subjectivity, agency and freedom are theorised in the contexts of feminist research encounters. The chapter has discussed in detail what reversed research methods could be giving a detailed account of the production process of my ethnography and short documentarist videos over the past eight years. By referring to the process as 'stumbling scholarship', this chapter has aimed to illustrate how, despite the aspirations written into research-funding applications and initial attempts at research, methodologies and data collection change over time - and to validate claims 
of fulfilling ethical requirements, solidarity and care, they must. This chapter suggests that moving from fables and peace brands towards subaltern conceptualisations of peace requires not only decolonisation of academic knowledge production practices, but also recognition of the fragility of those who brand themselves through the notion of the 'success' of the peace process and, further, how such peace mediation brands sustain themselves by relying on the hegemonic militarist masculinity enforced in Aceh through the peace process (Abdulah 2018). 


\section{Kota Madani (Civilised City) and the Struggle to Define Ideal Womanhood}

\subsection{City in Transition and the Rise of Sharia Populism}

In December 2015, Mila, a henna tattooist, stares into the distance of a quiet early afternoon in Taman Sari (Fragrant Gardens) public park.

They say the municipality will close down this park for a year and a half. What happens to my family during that period? Where will we go? How will we make a living? There are no alternative locations as good as this; people do not spend hours at the beach of Ulee Lhee as they do here. I don't know.

Extract from a video shooting in December 2015

Mila is a tsunami survivor from Northern Sumatra. Newly married to her South Acehnese husband and pregnant with her first child, she climbed to the second floor of her neighbour's house as the tsunami struck in December 2004 and watched her home and the neighbourhood being demolished by the crashing waves of the Indian Ocean. In 2016, as pre-tsunami migrants to the city, she and her family live in a 'bad neighbourhood' - as it is commonly known - in a post-tsunami-constructed, 'six-by-six' house, earning a living as a street vendor in the park. For Mila and her husband, with whom she was reunited after the tsunami, the transformation and reconstruction of the city have been accompanied by everyday concerns, such as worrying about the weather and trying to follow the recreational trends of affluent middle-class families - both of which have a huge impact on their livelihood - and dreaming of a better life: good schools for the kids, a safe and healthy living environment and a community to belong to. For Mila, there has been the additional task of adjusting to the 
expectations attached to being a respectable and pious Muslim woman after her marital conversion to Islam.

A year later, in November 2017, she and her husband watched the short documentary, Dreamcatcher (06:24), of their everyday lives in Banda Aceh, made suggestions on how to edit it and gave an update on their situation:

All the motorbike rickshaw equipment that was kept in front of the house was stolen and we could not earn a thing for three days. We sold some toys, such as the train. With the profits we bought other toys that were lost. The ball pool, generators, fishing ponds, the rickshaw. Worth 28 million. All the henna materials were also lost ...

We arrived in Aceh [as newlyweds] with capital of 15,000 Rp. We sold the motorbike rickshaw and rented one in 2003 and continued doing that for a long time, until the tsunami. All in all, ten years, and then had to start from scratch again. Initially we eloped because of different religions. Right now, our economic situation has started to improve. My sister-in-law is educating her two children. We've been able to start our own business with a loan from the bank ...

We should not be lazy. Do not be discouraged and do not despair. Be patient, pray, and try. People need to be diligent about fulfilling their own needs, yet the government should pay attention to the fate of people who are like us. Right now, we survive thanks to our own abilities. We got no help from anyone. We've survived from day one and have cried due to the losses. Our luck is that we had the toy train business and we got capital when we sold it for 10 million.

The park had been reopened after the tsunami in March 2007 with international tsunami aid funding and reconstruction shared between governmental support, Catholic Relief Services (CRS) and the Mercy Corps. The director of CRS operations in Aceh said in their press release:

It's a public space that symbolizes recovery, renewal and healing in the entire community ... It is our hope that Taman Sari will enable the people of Aceh to continue to improve their lives after the nightmare of the tsunami, and realize their full human potential.

ReliefWeb 2007

The Mercy Corps, another international non-governmental organization (INGO) present in Aceh, constructed a 'kids' rock', which they said was inspired, firstly, by the Teardrop Park in New York, but also by "gunongon," which represents the play hill for the wife of the Turkish Sultan who ruled the area four hundred years ago' (Christensen 2010). This statement, which mistakes the Acehnese Sultanate for a Turkish one, innocently aligns with Hizbullah Tahrir's (HT) transnational Islamist campaign in 2015, discussed later in this chapter. 
Yet, this mistake or, rather, the active interpretation of the park's history and that of Aceh is a prime example of how cities, parks and ideas about cities and their citizenry are constantly imagined and remade. In fact, as previous research has pointed out, between the Aceh Sultanate and post-tsunami park reconstruction, the park also played an important role for the Dutch as a public park. After the independence of the Republic of Indonesia, a monument to the Declaration of Independence was erected in the middle of the park in 1974 to commemorate the unconditional surrender of the Japanese to the Allies. Later, just before the elections in 2014, the monument was repainted with the yellow and green colours of Banda Aceh city. After its closure in 2016, the park was reopened as Bustannusalatin Park in 2017 with a newly built museum and information centre, celebrated with the following headline, 'Bustannussalatin, new Instagrammable face of Taman Sari Banda Aceh' (Serambi Indonesia 2017). The new plan, proudly represented in photographs of the municipality government building, meant that entrepreneurs such as Mila had to look for alternative locations for their livelihoods, as most of the space that had been provided for various entertainment equipment is now under the steps of the main Bustannusalatin information centre.

As Silvia Vignato has pointed out, Islam - or, as I would add, reconstruction of the city in accordance with its Islamic past - cannot be considered separately from the material and political environment in which the city's residents live (Vignato 2012). Expressions and struggles over sovereignty and identity - of 'who we are' as Aceh and the Acehnese - which lie at the core of attempts to solve the armed conflict in Aceh, must, therefore, also be connected to struggles over political change and the conflicts that arise from different kinds of transformations taking place socially, politically and economically. As Vedi Hadiz $(2016,160)$ has suggested, 'these conflicts may involve a range of social agents residing within both the state apparatus and private business as well within broader civil society'. This ties the links between 'people' and locations, such as Taman Sari or Bustannussalatin, to longer constructs of social memory and collective experience. Christine Schenk (2019) has also suggested that such spatial and legal orderings affect the security of the body as 'the body is the site where the geopolitical is produced and known' (Schenk 2019, 1132, quoting Smith 2012, 1518). Earlier research (Robinson 2009; Srimulyani 2012; Rinaldo 2013; Taylor 2015; Kloos 2017; Samuels 2019) on the rise of political Islam as a result of the fall of the Suharto regime in Indonesia, also applicable to Aceh, has underlined its multifaceted effects on the government's gender policies, but also its creation of new openings for the female ummah. The question that arises here concerns the ideas of masculinity, femininity and gender relations that emerge from such openings and articulations (Ayubi 2019a, 40-42) and the spaces of negotiation that matrifocality provides for those Acehnese women whose life worlds, instead of the privilege of material and land-based assets, focus on their bodies as a site of sexuality and fertility (Srimulyani 2010; Vignato forthcoming). 
The rest of the chapter enters the city of Banda Aceh at a strategic moment when its leadership was actively constructing the city and its citizenry as kota madani, a civilised Islamic city. Sait Abdulah (2018) has suggested that, to counter the emergence of the militarist hegemonic masculinity and extractive political economy of the GAM ex-commanders who rose to prominence in the aftermath of the Helsinki Memorandum of Understanding (MoU), the marginalisation of GAM's civilian elites has triggered the active construction of a civilian alternative, one advocating Islamic values and moral principles, rather than the formalisation of Sharia law (Abdulah 2018, 130-131).

Following in the footsteps of the legal framework, the policies of Aceh's female mayor, Illiza, and the activism of a number of civil society actors, the aim of this chapter is to illustrate the ongoing contestations over the nature of the ideal city and its gendered citizenry. It unfolds as follows. The first section reviews the provincial legal framework under which the city and its citizenry operate - that is, the laws that govern Islamic ethics, morality and sexuality. The second part of the chapter focuses on articulations concerning the civilised Islamic city and enactments of amar ma'ruf nahi mungkar (enjoining what is right and forbidding what is wrong). The fourth and fifth parts focus on the role of Mayor Illiza as a female leader providing advice and acting as a role model for ideal womanhood, and the final section presents two examples of the contested public sphere insofar as it concerns women's respectability: Hizbut Tahrir's 'Campaign on Shariah and Women' and the International Women's Day (IWD) celebration in 2015.

\subsection{Governance of Gender and Sexual Politics: Colonial (Dis)Continuities?}

Legitimate forms of gendered expression, sexual intimacy and conjugal practices are currently governed in Aceh by the legal framework that has been put in place over the past 20 years as part of peace negotiation processes on the special status of Aceh within the Republic of Indonesia (1999-present) (Schenk 2019, 1129). Special laws in 1999 and 2001 granted Aceh autonomy over its economic, religious, cultural and educational affairs, and the 2005 Law on the Governing of Aceh strengthened the legal foundation for implementation of Islamic and Acehnese customary law (Feener 2013, 146). The granting of special Islamic status to Aceh in 1999 can be seen as the negotiated result of a struggle in a longer decolonialisation process - initially involving the Dutch, later the Indonesian Government - that some Acehnese still consider incomplete. (For a detailed account of Acehnese ethnonationalist history and the decolonialisation process, see, e.g., Aspinall 2009b.) The special status is also used by Indonesian and transnational Islamist movements in their efforts to attain their goal of a new caliphate. On the other hand, others locate this struggle directly 
in the Shariatisation of Aceh and the rise of political Islam globally, including in Indonesia in President Suharto's post-authoritarian regime (1965-1998) (Azra 2000; Effendy 2003; Ichwan 2007). This section provides a short overview of legislative changes that have focused on Islamic piety and morality.

The special autonomy laws of Aceh allowed the development of substantive Sharia legislation (qanuns) which, especially during the early years, focused on Islamic traditional ethics and morality - banning alcohol, gambling and nonmarital intimacy. ${ }^{1}$ Among other things, they introduced the obligation for all Muslims to observe Islamic law in its totality ( $k a f f a h)$, marked the formation of the Shari'a Police (Wilayatul Hisbah, WH) and promoted an obligation to wear Islamic dress that is based on the gender binary (Feener 2013, 137-146). Yet, it was the first decade (2005-2015) of the implementation of the MoU, signed between the Free Aceh Movement and the Indonesian Government in Helsinki, that fuelled new dynamics and debates over the development of Sharia legislation, including the unified code of Islamic criminal law (Qanun Jinayat) (ibid., 146-147). These pieces of Indonesian national and Acehnese provincial legislation represent an ongoing struggle for power and legitimacy among the central government, national and local legislators, national and local political parties established as a direct result of the MoU, the diverse influence of local religious leaders and revivalist religious movements, Acehnese Sharia bureaucrats, and a vibrant and multi-voiced civil society. Such processes and the accompanying, ongoing debates also reveal an intimate connection between gendered sexual ideologies, post-conflict state building, and unfinished negotiation of the relationship between legitimate sexualities and gender expressions, Acehnese ethnonationalism, the Indonesian state, Islam and decolonialisation (Jauhola 2016, 347). Christine Schenk $(2019$, 1134) has suggested that a particular interpretation of Sharia in Aceh has reiterated notions of State Ibuism and the concept of kodrat, whereby women are prescribed, on the basis of biological determinism, to belong to the domestic sphere (see also Jauhola 2013). This new form of biopolitical governance using a gendered and sexual political legal framework is reinforced through the public punishment mechanism of Friday canings, but also managed locally by village governance structures that can range from lecturing by village elders to enforced marriage and physical and emotional abuse and punishment - often justified as a mechanism of 'care for moral behaviour' (Schenk 2019, 1134).

After a full decade of drafting and several rounds of debates in the local parliament (2005-2015), the Islamic Criminal Law was finally passed in September 2014. The law criminalises certain types of consensual same-sex acts, namely liwath (defined as male-to-male anal sex) and musahaqh (defined as sexual arousal between females that is caused by rubbing their vaginas or other body parts). It further reiterates the criminalisation of $\mathrm{khalwat}^{2}$ (inappropriate mixing of the two sexes), and includes new prohibitions for zina (fornication or adultery) and ikhtilah (physical affection and/or sexual intimacy between an 
unmarried couple). The content of the drafts stipulating the crimes and their punishments has varied over the decade of drafting, with the stoning to death for married offenders of adultery, for example, being dropped from the list of punishments in later versions (Grossmann 2015). Commonly reported in English-speaking media as the only region in Indonesia to criminalise consensual same-sex acts, the formalisation is part of a wider trend in the Indonesian archipelago: the province of Southern Sumatra issued a local regulation in 2002 $(13 / 2002)$ criminalising homosexual and lesbian acts, and separately specifying sodomy crimes. Furthermore, the anti-pornography bill passed by the Indonesian Parliament in 2008 classifies necrophilia, bestiality, oral sex, anal sex and 'lesbian and gay sex' as 'deviant sexual intercourse'. Although the bill does not criminalise homosexuality or homosexual acts, Saskia Wieringa argues it provides an opening for so-called community action against gay and lesbian people, as in the case of Islamic criminal law in Aceh (Wieringa 2011, 787).

The same-sex acts and their punishments stipulated in the Qanun Jinayat (100 lashes and a maximum fine of 1,000 grams of fine gold or imprisonment for up to 100 months) were not part of the first draft made by the Sharia Islam office and the Office of Justice of the Governor. The pressure for their inclusion came from the Ulama Consultative Assembly (Majelis Permusyawaratan Ulama, MPU) whose role is to take a formal stand in interpreting Sharia Islam and, for example, in identifying deviant doctrines and overseeing local religious boarding school scholars (ulama dayah). Support for the provisions also came from some Acehnese and Jakarta-based senior female officials/activists taking part in post-tsunami reconstruction. Rumours were spread of 'lesbians' among the Acehnese non-governmental organisations, along with claims that 'it' had to be stopped before it became infectious. ${ }^{3}$

One result of the aim to settle the armed conflict in Aceh is that the province has been recognised nationally in Indonesia as a laboratory for the development of Sharia legislation for other provinces that have similar religious dynamics or aspirations for full implementation of Sharia law. On the other hand, civil society organisations, women's organisations included, critique the focus of populist political elites on policing sexual morals in Aceh, pointing out that it moves attention away from solving structural poverty, the predatory political economy and investment culture, corruption, hierarchical post-war patronclient relationships that maintain the commander-combatant networks, and military intervention in Acehnese economics and politics. ${ }^{4}$

It is also telling that the two well-known and respected Acehnese women's rights activists - one with a law degree and a background in legal aid for women, the other a graduate in Islamic Studies from the State Institute for Islamic Studies - who took part in the drafting of the bill in 2009 were subjected to regular insults and accused of being lesbians and kafirs (infidels) by conservative religious leaders also taking part in the process. This resulted in one activist leaving the drafting team before it was debated in parliament, and the other when the third parliament hearing led to the realisation that the parliament favoured corporal punishment (Grossmann 2015, 106). Using 
the language of immorality and sexual deviance to demonise women's political mobilisation has a long, violent history in Indonesia that draws from the sexual politics of the coup, the massacre of the political left in 1965 to 1968 and the anti-communist propaganda of the New Order in Indonesia (Wieringa 2002). Furthermore, the anonymous accounts of what happened in Aceh during the days of drafting the law make it clear that the label of 'lesbian' was not only used by men (parliamentarians, religious leaders and state bureaucrats), but was also spread by women activists with close connections to the current mayor of Banda Aceh. Zina accusations are extremely effective ways of silencing political dissidents in Aceh, as the process of consolidating the Islamic criminal law illustrates. Ultimately, there were no women activists to defend their cause in parliament.

Yet, some Acehnese women activists have migrated outside of Aceh and continue to work in Jakarta-based organisations to challenge the legal framework within the overall structure of the Republic of Indonesia. For example, Women's Solidarity for Human Rights (Solidaritas Perempuan) has specifically analysed the legal framework resulting from the peace process, and partnered with the Institute for Criminal Justice Review (ICJR) to provide an analysis for the UN human rights forums, such as the Universal Periodic Review of Indonesia in 2017. In the review, a number of member states make recommendations indirectly referring to the case of Aceh, but also suggest more general pressure to

... ensure that existing legal and constitutional provisions protecting human rights in particular freedom of expression, association and assembly are fully implemented nationwide; repeal discriminatory local by-laws contrary to the Constitution of Indonesia; prioritize progress on equality and non-discrimination, including in relation to lesbian, gay, bisexual and transgender persons; take action to prevent extremist groups from harassing, intimidating or persecuting religious and other minorities; and provide human rights training to officials in the legal and judicial system (Ireland).

UN Human Rights Council 2017, 5

In its reports, also shared with the Office of President Ahtisaari in 2018 (see Chapter 1), the organisation takes as its starting point the following sentence from the MoU:

The legislature of Aceh will redraft the legal code for Aceh on the universal principles of human rights as contained in the International Covenant of the United Nations on the Rights of Civil and Political Rights and on Economic, Social and Cultural Rights.

MoU Helsinki, para. 1.4.2

The reports point out that, despite this articulation, since the MoU, the Government of Aceh has passed a number of laws that particularly discriminate 
against women and are in conflict with the Indonesian law on CEDAW (Convention on the Elimination of all Forms of Discrimination Against Women; Law 7/1984). More specifically, Islamic criminal law is in conflict with nine other national and international laws, such as the Indonesian Criminal Law, the Law on Human Rights, the International Covenant on Civil and Political Rights, the UN Convention Against Torture, the Criminal Law on Juvenile Convicts and the Child Protection Law. The organisation's advocacy takes as its starting point the fact that in the peace negotiation rounds held in Finland, the conflicting parties consented to implement the well-being and prosperity of all Acehnese, both men and women (see Chapter 1). The organisation's opening remarks to the meeting held at the office of President Ahtisaari were: 'It is important that the Government of Finland, and the Chairperson of CMI [at the time of the signature of the $\mathrm{MoU}]$ take responsibility for the violence and discrimination against women in Aceh by abolishing such discriminatory regulations.'

The dynamics of the special status of Aceh within the framework of the Republic of Indonesia play themselves out at the national level as follows: if, after lobbying for a judicial review process by national commissions (such as the Commission of Human Rights, or Violence Against Women) or civil society organisations, the Indonesian Government takes a critical stand on Acehnese local regulations in public - such as the recent case on Muslim dress in February 2016 highlighted by the Minister of the Interior - the Acehnese Government and legislators can react by using the special status and Islamic identity of Acehnese as justification for their right to govern such matters. They then condemn such attempts by referring to conflict dynamics, and claiming continuous interference in Acehnese matters and the undermining of the sovereign power of Aceh. In Aceh, meanwhile, criticism of the internal implementation of Islamic law and local regulations in public is rare, given the risk of being labelled a kafir (infidel), Western agent or non-Acehnese. Thus, individuals and organisations carefully evaluate the pros and cons of speaking out against the political and religious elite, especially when it comes to using national and international frameworks, such as laws, conventions or even inviting guest speakers and forming networks (Grossmann 2012, 2014, 2015; Schenk 2019).

Two decades into the new legal framework developments, local women's organisations and experts with Islamic jurisprudence have managed to carve out a specific role in negotiating legal norms through formal governance and legislative processes. In the public sphere, the space for manoeuvring is often limited to males (but not entirely, see general analysis of the agency of female religious leaders, e.g., in Afrianty 2015; Srimulyani 2015) holding specific positions of power, such as the state Shari'a bureaucracy, Shari'a court judges, ulama council members or Islamic studies experts. !In the case of same-sex acts, one of the very few to make public statements beyond referring to LGBTI and homosexuality as forbidden (haram) or $\sin ($ dosa) is Professor Syahrizal Abbas, the former head of the Shari'a Office in Aceh. Known for his generally liberal and 


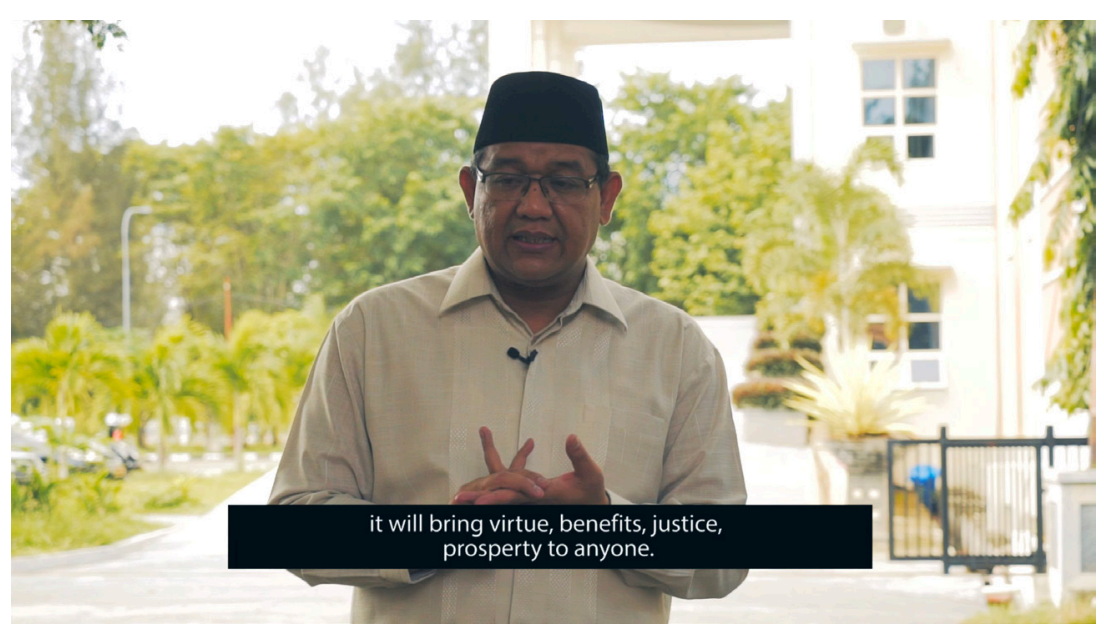

Video 4: Shari'a and visions for peace: blueprint for just and equal Islamic law (10:29).

Source: Scraps of Hope.

To watch this video, scan the QR code with your mobile device or visit DOI: https://doi.org/10.33134/pro-et-contra-1-video-4

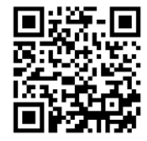

ambitious ideas about the blueprint of Islamic law implementation in Aceh, he was replaced with a more conservative head only a few months before the 2017 governor elections.

Shari'a and visions for peace: blueprint for just and equal Islamic law is an interview that brings together the December 2015 Paris climate change negotiations with the head, at the time of the recording, of the Sharia Department Professor Doctor Syahrizal Abbas. The video focuses on the vision for the blueprint of the formalising of the Sharia Islam of the Sharia Department in a globally contested political sphere on Islam. The video introduces the Islamic concept of equilibrium - the necessity of balance between humans and environment, and is contrasted by Professor Abbas with the reality in Aceh of the increased extraction of natural resources, which has led to cascading disaster risks and poverty.

In the video, Professor Abbas makes the argument that Sharia should focus on social and economic justice, but elsewhere his public statements have negotiated between liberals and revivalists, both internal and external. In a Reuters video interview in 2014, ${ }^{5}$ Abbas asserts that the Islamic Criminal Law in Aceh does not violate human rights as, according to him, Islamic law only forbids same-sex acts and marriage, not living or sleeping together. However, when the Banda Aceh municipal government released online news in March 2016 of the mayor's 'road tour on LGBT issues' to the law students of the University of Syiah Kuala, Abbas' public statements claimed that homosexuality was 
unnatural and curable and that the emphasis should not only be on the law's preventive possibilities, but also on providing a way for LGBTI conversion and rehabilitation. Details of the history of regulating same-sex desires and gender plurality are discussed in Chapter 6.

Another contested and gendered area is the question of the formality and governance of marriage, and its connection to polygamy. A number of years ago, high-profile women's organisations, the provincial women's empowerment office and Acehnese female legal experts started openly advocating the fight against nikah siri, 'secretive marriage' or 'village marriages' (Vignato 2012) marriage that is not formalised or registered by the state or the Department of Religious Affairs. Previous research suggests that advocacy against nikah siri intensified as a result of international humanitarian aid that targeted 'empowering women' - formalising women's guardianship rights, and children's rights to a birth certificate and to enter the state school system - but that has not necessarily been attentive to the needs and strategies of women - rural women in particular (ibid., 253-254). 'Secretive', 'village', or simply informal or unregistered marriages were particularly common during the conflict, comprising at times a form of a mundane resistance to the Indonesian State and a strategy to 'preserve autonomous vitality' (ibid., 252), and administered by the civilian government of the Free Aceh Movement (Abdulah 2018, 40). Yet, anecdotes from Aceh after the peace accord also suggest the relevance of questions of economy or, rather, the high price of the bureaucratic process of getting marriages registered (see also Schenk 2019). In 2015, the media reported that the Sharia court - in collaboration with Governor Zaini Abdullah, the Department of Sharia Law, and the regional office of the Ministry of Religion - was granting formal certificates of marriage and birth free of charge to 125 couples from five conflict-affected districts, all whom were considered impoverished conflict victims. The same initiative was planned for another six Aceh districts (Antara News 2015).

Another gendered aspect of such marriages exists (discussed in greater detail in the next section); as Vignato (2012) suggests, nikah siri is also used strategically by both men and women to avoid accusations of having broken the Islamic law of khalwat, but, as the case illustrates, it is also used by men who are already married. In such cases, the first wives are not always aware of the second marriage, and, as the video Solving nikah siri - unregistered marriage illustrates, the results of attempts to address the problem can be unpredictable. In a case illustrated in the video, one couple solved their internal conflict with legal assistance from the women's empowerment office in mediation, resulting in a situation where the husband and the first wife gained informal and formal custody of the child born in a nikah siri relationship. The problem remains of the consequences to the second, or nikah siri, wife, who was left without rights regarding the child's custody, which was assigned to the husband. This raises broader questions of who is affected by the legal/spatial ordering of marriage and the rights of the marrying parties, which resonates with Smith's claim that the body is 'the site where the geopolitical in produced and known' (Schenk 
2019, 1132, quoting Smith 2012, 1518). However, as Vignato (forthcoming) points out, 'village marriages' have an important function in matrifocality: they enable sexuality and fertility without sin and keep these connected to the female's mother's home.

The wider issues of polygamy and nikah siri were publicly debated again in 2019 when the provincial legislature (the DPRA) was debating the draft law on family protection. The last prominent discussion had been when the law on population administration (6/2008), which regulates the registration of marriages and divorces, was debated by the DPRA. Schenk's (2019) analysis focuses on how this process of legal ordering, or formalisation of Islamic principles, clashes with that of the local adat (local custom, customary law). A legal expert, known in the women's rights movement, had insisted that the authorities should gain access to birth and marriage certificates, allowing the formalisation or state registration of marriages (Schenk 2019, 1130). Schenk further suggests that the inter-legality of adat/Shari'a law has justified 'the tacit acceptance of unregistered, de facto polygamous marriages and divorces' (ibid., 1136).

The latest of the reforms, the Law on Family (Qanun Hukum Keluarga), was debated in public in 2019. This time, the women's organisations publicly opposed the draft, as it was on the verge of granting a man the right to marry another woman without his wife's (or wives') permission, if certain conditions were met, such as illness or an inability to have children, and if a formal remarrying certificate was issued by the Shari'a court. The tactic used by local legal experts was to focus on the fact that this area of law was already sufficiently regulated by national law, and any new provisions could potentially lead to contradictions (Jones 2019). Simultaneously, the rights activists, when interviewed by the national media, challenged legislative members to direct their attention to 'real issues', including inflation, increased poverty and climate-change impacts such as drought (n.a. 2019).

\subsection{Kota Madani - Towards a 'Civilised Islamic City'}

This section focuses on a specific articulation of a desire for social transformation: the conceptualisation of the vision of kota madani or the civilised (Islamic) city. The concept is in line with the idea of establishing Shari'a as the 'living law' in Aceh and moving towards the normative prescription of ideal values (Feener 2013, 261). The word madani has etymological connections with madinah or madaniyah, referring to 'place of obedience' or 'system of obedience' (Nasution et al. 2019, 10). Thus, Medina (established by Muhammad in 622) is regarded as the home of an ideal civilisation and the occupations of civilised society. The concept of masyarakat madani in Indonesian is often translated as civil society and theorised using Western conceptualisations. However, in the context of Aceh and Islamic studies, the references are more strongly focused on the ideals of governance that were laid out for Medina known as the Charter of Medina 
(Sahifat al-Madinah, Piagam Madina in Indonesian), which formed the basis of a multi-religious Islamic Medina.

The 2012 elected leadership (Mawardi and Illiza) developed the long-term regional development plan known as RPJMD (rencana pembangunan jangka menengah daerah) in 2012-2017, with the vision that Banda Aceh would become a model, civilised (madani) city. In the RPJMD document, this is described as follows:

The madani city is one whose inhabitants have faith and noble character, maintain unity, are tolerant of differences, obey the law, and have wide public spaces. In addition, the community participates in the implementation of development; it is inclusive and able to work together to achieve the shared goals it aspires to. This situation is expected to produce citizens of Banda Aceh City who have a friendly, obedient, peaceful, prosperous, high self-esteem, and civilised identity.

Pemerintah Kota Banda Aceh 2012, 250

This vision was complemented by a seven-point mission:

- Improving the quality of practicing Islamic Sharia in kaffah (full)

- Strengthening good governance

- Strengthening the democratic economy

- Cultivating communities that are intellectual, healthy and prosperous, mastering various sciences, technology, art and culture

- Continuing Islamic tourism infrastructure development

- Increasing women's participation in the public sphere and child protection

- Increasing the role of the younger generation in providing strength

Nasution et al. 2019, 13

The first priority in increasing women's participation in the public sphere was identified as making them 'citizens of a civilised city' (warga kota madani), something seen to be part of the wider agenda of mainstreaming gender (pengarusutamaan gender, PUG). Thus, it is clear that the ideal city was foreseen as gendered, and that women had specific roles in gendering it in the direction of the civilised Islamic city. This chapter follows the articulations and contestations of the ideals that are narrated as suitable for women. In the remainder of this section, I focus on the ways in which Illiza, when given the position of Mayor of Banda Aceh on the death of Mayor Mawardi Nurdin in February 2014, started outlining this vision in her public appearances and during her time in office. In the following, I analyse one election debate on Aceh TV, aired during the 2014 election campaigning, in which Illiza participated.

During a commercial break, the following announcement was aired:

The Forum for Religious Harmony asks that the religion is not politicised in the 2014 general elections, including through religious campaigns by 
legislative candidates in political parties. The forum also recommends that religious leaders remain neutral in the forthcoming elections.

Aceh TV, 3 April 2014

After this message, candidates were given the chance to respond to the question of why they should be elected, then the programme included a section where the viewers were given a chance to ask questions of the candidates. The dialogue that took place is as follows:

Presenter: Tonight we have an interesting topic to discuss, how the city of Banda Aceh may become a model for a madani (civilised) city. Why should one choose the PPP (Partai Persatuan Pembangunan, United Development Party)?

Illiza: Party politics can be based on agreement. In that joint policy we develop a strategy to respond to people in ways that they can agree with, that have character. PPP is a party that promotes Islam, a party that is really led by religious leaders [ulama]; the aim is Sarekat Islam, we have Nasdatuh Ulama [NU]. We have Masumi and also Parsi. But why choose PPP? Because at this point in time, people also chose it when I became the vice-mayor. Of course, when I gained executive powers, the vision and mission we launched at the general election was shared with people. Inshallah with God, it also has to receive strong support from the legislative body to build synergy, synchronisation, partnership, so that there will not be many conflicts. Of course, the goal of PPP and all of the candidates is that this house of Islam can become a model so that we can continue in 2017.

After the rest of the candidates made their introductory remarks, the presenter opened the floor for viewers' calls, which were dominated by questions addressed to Mayor Illiza.

Presenter of Aceh TV, Qudus Husein: We now have Mr Jamal from Peunayong. Mr Jamal, please.

Pak Jamal, resident of Peunayong: I am very sorry, we talk about being civilised amongst the residents of Peunayong. In what ways is it civilised? Before we can make civilisation, please socialise the idea first, because our people remain confused. People do not know, Mam. That all is my recommendation. Aleikum.

Presenter: Madam Illiza ...

Illiza: Yes sure. This means that, in order to be civilised, it really means building Ummat. It means our akhlak, ${ }^{7}$ and developing it in accordance with adat and ethics. It means how civilisation arises from the people. It means our relationship with our Creator. It means our religious practice, it means participation. There are [religious] differences, even Islam is Rahmatan nil Alamin. ${ }^{8}$ 
Presenter: Thank you Mam. Here is Mr Zulkifil from Darussalam ...

Mr Zulkifil: Students are still in the streets in the middle of the night until 2 pm, young children with bad habits ...

Presenter: There is appreciation ...

Illiza: Our lives are governed by Allah, but with how we behave comes the perception that God has passed it. In response to Mr Zulkifil, there should be a sense of ownership from the community, so that all of us, despite the feeling there are many Gods we follow, arise to build this city. It starts from our own hearts, and of course people must strive towards madani, what it means to God, following all God's commands, leaving it all to Allah, and living with compassion. It means people having self-respect and love for the self and not humiliating oneself. Thus we become the universe that we are according to Allah. It also relates us to family, and our relationship with the environment. Realizing these ideals leads to harmony of the person, but also to that of the city and nation, that of the whole of Indonesia.

Banda Aceh is known as a city of Shari'a Islam, the first in Indonesia. Hopefully all its residents realise Islam in their hearts, not as something that is converted, but as arriving in their hearts. It means full acceptance, both rationally and irrationally. Verandah of Mecca. The atmosphere of the religion, the culture of religion is on the increase. When we talk about civilisation [madani], we of course have to think of it in our own context, in accordance with our times and how technology can be used in a positive way. It means that governance and the government has to be a civil, streamlined, and accountable government. It means respecting differences because there are also non-Muslims living here in Banda Aceh. Our religious community (Ummat) has to guard these principles and I guarantee that if I continue leading Banda Aceh, the relationship between people will be maintained because Islam is Rahmatan nil Alamin. That is not only true of Islam, our Muslims also have moral character [akhlak]. What we do not want is that people live as they wish; we have clear regulations on that.

Presenter: We have Teunku Muh from Krueng Raya on the line, please.

Teunku Muh: So, can I use Acehnese language, can I?

Presenter: Of course sir. On Aceh TV you can use Acehnese.

Teunku Muh: Ok. Assalamu'alaikum Madam mayor ...

Illiza: Walaikum salah warahmatullah wabarakatuh ...

Teunku Muh: My father and all of us were in the PPP, around 1987-1992.

I am no longer active but in my heart I still belong to PPP. Because you have power, and like you say, Aceh agrees to become a Civilized City of Sharia Islam, right? This means, we, and the people, are responsible together ... You just have to provide an input, because you have the power, right? Please, go to Peunayong. Around the Hotel Sultan there 
are many beauty salons that do not do what the store front claims. So please do not give out permits to open new salons, because in these salons they do other business than beauty business and that violates [the law] and is immoral. I don't mean all the salons, because there are those that truly work as they should. It makes me embarrassed, when visiting Medan; there are places for prostitution, but there are places like that also next to Baiturrahman Mosque ... So, if people take action into their own hands, we are told we do not believe in the legal system, right? So therefore I again ask you and the legislators from PPP. Don't you believe in the legal apparatus?

So because I reiterate, I beg you Mam, and the board member of the PPP in the area of Ketapang also but ... If this still happens in Nanggroe Aceh, inshallah - the truth must be defended. And if you intend to go shopping do not let the officers [anak buah Ibu] know because there are those that are untrustworthy in your office; try one day to come down [from your office] to see it. Forgive me if I'm speaking a little rudely, because I am ordinary and stupid. Wasalamu'alaikum warah matullah wabarakatuh.

Illiza: Yes, this is certainly an issue which we worry about together ... [It is] also why in the legislature, we need the support of the United Development Party. When I became the person given the trust to continue the leadership of Mr Mawardi Nurdin which we jointly want, Banda Aceh became the model city of Madani. As Teungku explained, the moral tsunami in Banda Aceh has become a great test for the Acehnese people. And we know Banda Aceh as a provincial capital; those who arrive here to improve the well-being of their families, conduct their activities in ma'ruf [good] and mungkar [bad] ways.

Now for the bad ways, we really hope that all residents are involved in amal ma'ruf nahi mungkar [ordering all that is right and prohibiting all that is wrong, Al Imran 104]. Because it becomes a matter of qu anfusakum wa ahlikum naran [saving yourselves and your families from Hell, At-Tahrîm 6], we return to our Ummah, we build a madani society. What we see in our situation is that the role has to be played by government, society, and youth. Youth should be at the front gate as the pagee gampong [vanguard of the village]. If youth has risen up to fight against the perpetrators of immorality, certainly people cannot do anything. They definitely have a soft spot. Yes, that's my hope of course, friends who are here. Yes, every time I visit neighbourhoods in the middle of the night, my husband and friends witness and take part because I always tell them to support me together. We will fight and people will give their trust, if at night time, they do not leave me alone. So they become Allah's volunteers; we all become volunteers of Allah and I also take part at night, although I am a government official and 
they are volunteers. I often go by car together with my friends. So I think that the condition can get great support, they can sit in the legislature which will create harmony between executive and legislative. Political power that we can strengthen, so that our commitment will be more obvious. The minimum is that we can have one faction to fight this together.

As early as 2012, after the mayoral elections, the municipality had supported the establishment of Tim Amar Makruf (TAMAR, amar - command from God, judge, ruler; makruf/ma'ruf - good) and the Masjid Brigade at Gampong Peunayong. These teams were mandated to implement Sharia law in urban neighbourhoods in Banda Aceh. Although framed as a return to the ideal society of khilafah, ${ }^{9}$ such structures also bear a resemblance to the New Order, wherein Suharto's regime, as the authoritarian power of 'the Development', established structures that connected the central government's powers to those of the neighbourhoods, in that the government established women's organisations and paramilitary organisations. Mayor Illiza used to talk about the importance of TAMAR teams as Sharia Police (Wilayah Hisbah, WH) was unable to respond to all the city's needs, framing them as a concrete way of striving towards the civilised city (kota madani). Not everyone, however, welcomed these teams without reservation. A municipal legislative member complained in the media that although he had no reservations about such teams, their establishment and deployment was never debated in the legislative body. David Kloos has earlier suggested that the focus on morality in Aceh has been on developing the good characters (akhlak) of its people, aiming towards piety and thus self-governance of behaviour. The example of the municipality of Banda Aceh (see also Chapter 5), however, suggests that during Mayor Illiza's term, formal government structures extended their support to the implementation of Sharia law; perhaps rather than seeing these as totally separate spheres of religiosity, they were intimate parts of the dream of developing Banda Aceh as a kota madani. Instead of simply drawing on Acehnese forms of adat neighbourhood governance, the formation of TAMARs went hand in hand with other Islamic social engineering innovations, such as the muhtasibs, who had the role of overseeing the implementation of Shari'a principles in trade, much as TAMARs attended to the sexual morality of the citizenry.

Contestation over what was meant by amar ma'ruf nahi mungkar (enjoining the good and forbidding the bad $)^{10}$ in the context of post-tsunami and postconflict Banda Aceh was apparent during my ethnographic research. Here, I provide a couple of examples of the ways in which the Islamic Defenders Front (Front Pembela Islam, FPI) strategically used the public sphere and also the municipal government's platforms, such as the open monthly Friday da'wa, for their own purposes, and how several attempts to conduct khilafah were appropriated to these ends.

Roughly two weeks before the elections in 2014, the municipal government of Banda Aceh organised its monthly open da'wa lecture, inviting the head of the FPI to address a Banda Acehnese audience. Due to the ill health of the 
FPI head, Ahmad Sabri Lubi, the address was delivered by Habib Idrus AlHabsyi instead, with the title 'Upholding amar ma'ruf nahi mungkar in Madani City'. These monthly da'wa lectures were a trademark of the mayoral practices of Mawardi and Illiza, part of the implementation of the vision for a kota madani and the seven-point mission of the city organised jointly by the Dinas Syariat and municipal government under Illiza's leadership.

The audience, as I was told by the head of the city's BPPPA, was drawn from schools, in order to specifically target Banda Acehnese adolescents. It began with the reading of the above verse from the Qur'an and a reminder to the audience that ' $\mathrm{t}$ ] his is obligatory, as Allah told to Muslims'. Dividing humanity into those who do good and those who do bad, Al-Habsyi went on to remind the audience that the tsunami occurred in Aceh because of the way in which humans themselves behaved: disasters occur if people are not responsible. Giving an example of a tsunami-demolished village, he continued:

So, don't mess around, we forget amar ma'ruf nahi mungkar ... Why did God destroy the village? They don't care about their village, they just are immersed in their own selves. They are only praying, they are only fasting, they are only giving zakat. But if the neighbours commit adultery, the village deals in booze, the village loots, they don't care.

He continued by giving examples of women who do not follow akhlak (moral precepts) or who are 'ungodly', even mentioning that the Indonesian Government (under the rule of President Jokowi) was undermining religious leaders and demanding that they defend their status and religiosity vis-à-vis pancasila: how pesantren (Islamic boarding schools) are shut down when labelled antipancasila (anti-constitutional) and terrorist, but prostitution remains in the cities. Simply put: the government was not paying attention to amar ma'ruf nahi mungkar. For the approaching elections, it was recommended that people only vote for parties that would ensure the full implementation of Sharia. Aceh, however, was mentioned in the talk as a promoter, a 'true reference', and an example to other regions in Indonesia:

And hopefully inshallah in Nanggroe Aceh Darussalam ${ }^{11}$ will be a mirror as a role model that has been running the Islamic Shari'a and, more than that, can effectively run Islamic Shari'a. Inshallah ...

Alhamdulillah, in Aceh, hopefully our officials, especially our mayor, are willing to use Sharia, that they want to fight for Islamic Sharia. Hopefully, God willing, Aceh will be added again ... namely, in the establishment of Shari'a which can be an example to other provinces inshallah.

The church ${ }^{12}$ in Peunayong conducted Sunday mass for some time in early 2010s in a building that had been converted from a shop. The ground floor of the church consisted of three parts: the entrance from the street, the main 
hall with a stage and space for seats and audience (a wooden wall and another door separated the entrance from the main hall to keep the music and noise in), and a back space used as a Sunday school for children. From the stage there were stairs to the first floor. There was a back door from the Sunday school space to a narrow path behind the building, next to which was a deep, openwater gutter.

I felt comfortable, I fit in. From the first sermon, it caught me. I like the way that this preacher shared the Gospel. I am going to make this my church and still today I am loyal.

As a minority in Aceh, Banda Aceh, it is really hard to get a permit to build a church, to build a building and make it a church. It is nearly impossible in Aceh, in terms of a church. That's why they didn't wait for the permit but initially rented a house from the local people as a church, but with the permission of the owner of the house, of course. And people had been spying, the 'majority'13 in Aceh, had spied on the church and other churches.

On this particular Sunday, when the Sunday mass was being conducted (starting at $10 \mathrm{am}$ ), a group of men stormed into the church, smashing the wooden wall separating the entrance and the main hall and destroying all the church's material belongings (music equipment, AC, Bibles) as they searched for the priest. The priest and those involved in the service (such as musicians) wear a tie which identifies them. After they rushed in, the priest managed to run upstairs to the first floor and hide there. Others with ties took them off so that they could not be identified as being in charge of the service. As one church member described the event:

So there was one time we were worshipping, when suddenly there were other voices, other harsh voices from behind us and they were smashing the wall, trying to break in. We were worshipping at the time, with all the music on, and then, well, we stopped. And people just kept breaking in. The door, everything is just broken and people are screaming and shouting inside the church. Children were crying.

Then our ... pastor, he was on the 2 nd floor at the time. We tried to hide him because he was the target ... And we managed to hide him. Praise be to God, we managed to hide him. 'We' does not mean me. I was not involved with that because I was afraid because for my baby; my child was still a baby and I was running with the other mothers ...

People breaking in and then [smashing] our music instruments, our aircon and loudspeakers, everything. They just smashed it with anything they had. The chairs were thrown upside down, [it was] getting crazy. And they shouted at us people. The worship leader was standing right there in front of us in the middle of the stage and people 
shouted at him, 'Stop, we have to stop right now, no more singing.' They shouted at him as bad as - I don't even remember what they shouted but it was really bad.

What I can still remember right now is the people. Their faces and eyes were as angry as if we had really, really wronged them and they wanted revenge. And, thinking about it, I don't think they came from around there; they must be from somewhere else because I had never seen any of them before.

The situation was crazy, the children were crying. We have Sunday school so the mothers really quickly went and got the children and ran out the back door, just leaving everything behind no matter what it was. And the husbands tried to calm the situation, calm the wives, calm the children.

How do I say this? The majority tried to calm the people [the attackers] down. They tried to ask nicely, 'What is wrong?' But then I do not know what happened, because I was hiding; I had run out the back door with my children.

When the congregation realised the group had entered the church, many ran through the Sunday school and out the back door to the back alley and hid in a house close by, where they stayed for the next two hours or so. Susi told me that she was sitting in the audience with her baby and, when the group stormed in shouting, her first thought was to save and protect the children in the Sunday school. She rushed there, grabbed whoever she could, and went out through the back door. It was frightening, as the door leads to a very narrow path next to the deep water gutter. Luckily, the keuchick offered his house as a refuge, and Susi could return home with the rest of the family.

When asked how the children reacted, she said that they recovered swiftly when back home, and that she decided to calm down in order not to do anything that might cause her, her family or the community unnecessary backlash. Adults were traumatised and frightened, however, although Susi said that, as time has passed, she has been able to forgive the attackers for what they did.

The group that stormed in was searching for the priest, and when an ustad dressed in civilian clothes raised his hand with a Bible and said 'this is al-kitab [Quran]', they started beating him and he was later hospitalised.

But what I heard is that there was someone in our church [who] was holding a Bible and then a bad guy saw him holding it and thought that he was the famous pastor. He wasn't, he wasn't the pastor. He was someone who attended the church.

That bad guy was telling the other bad guys, 'Hey this is the pastor'. Just because of the Bible. And everyone tried to attack him. Tried to beat him up. But somehow he managed to get away from them. 
And another thing is that ... there was one older person, with a good outlook, people thought he was the pastor. And that got him beaten up and it turned out that he was not a pastor; he was one of the majority and went to hospital, got hospitalised.

He was like, no no saya bukan pendeta, saya bukan pendeta [I am not a priest, I am not a priest]! He mentioned some name, but I forget the name already. Saya, I am from this kampung [laughter]. What I know is that the pastor and his family hid in another home and then waited until help came.

One of the people who attended the church is kind of a police officer and called the police to ask for help, protection. And then at three or four o'clock ... [an armoured] car was sent to that pastor's house and the pastor came down from the hiding place and got into it. The bad people were still waiting there and shouted at him. It was in the news. It was on Metro TV.

One woman went back into the hall to search for her children, but was protected by others, who sheltered her with their hands and took her to a car outside the church. The attackers gathered outside the building and rocked the car, but she managed to escape and later found her children taking refuge in a house close by. There was a rumour that one week before the incident a man had entered the church during the service, stayed for a while praying and then left. The only person who noticed the visitor was the person in charge of welcoming the churchgoers at the door.

Later, when the local media reported on the case, they suggested in interviews that the keuchik of the neighbourhood had admitted he had been contacted by the FPI beforehand. This information is not verified, however, and is perhaps a media invention. Susi also says that the local media puts the blame on the church for not having a permit, although in some media coverage the priest has explained that in fact it had applied for a permit several times, without success. The church has since been offered another place to conduct Sunday mass.

Marjaana to Susi: How long did it take for you to get home?

Maybe two or three hours. I had to stay with a friend. I had to stay in Pak Keuchik's house. Pak Keuchick is like the leader of this little group of people. I had to hide there with other kids, other mothers, two or three hours. When everything was more stable we got home.

Marjaana: Do you still remember the feelings that you had?

I was so sad. So angry. I was full of hatred, I hate those people. I hated those people. I was so angry. We were trying to worship our God! We didn't do anything wrong. All the music and everything we had was 
part of the service. What did we do wrong? If we did wrong, come and show us.

I was like, I hated them. I hated them. But my pastor sent texts to all the people: 'Keep praying, don't hate them because they don't know what they did. Spread the love. They can only break the building but they cannot break the faith inside us.' That's what is amazing about my pastor ... he is a wise man. He is really wise. I was angry and sad, of course.

Marjaana: By the time we met in the early 2010s, six months later, I remember that you no longer had any regrets; you had shed that hatred.

After that, I thought that we would be left alone. See, the church in Banda Aceh is a branch of the Medan Church. So the leader from Medan came down to Banda Aceh just to calm us down, to comfort us, to strengthen us with prayer and said to us all: 'Don't worry, you don't have to hate. We keep on loving them as the Bible says, as the Gospel says, we don't hate people, we don't hate our enemy. We have to love them.'

So then, slowly, slowly, we accepted, I accepted that I am OK. They might never realise what they did. Because ... what I had heard is that some party was involved in this incident. The people actually got paid to attack us. To make a big riot ... [The] people were innocent actually; all they wanted was money. Because Aceh was never like this before. Aceh was peaceful place, especially Banda Aceh, though I couldn't find any [peace] in Medan. I have felt peaceful in Aceh before.

Just some politics got into it. The leader from the Medan Church came and comforted us and strengthened us and we, the [congregation], became closer than before, giving information, sending prayers, sending the best, and we kept going on, no longer at a church but in a cell-group now. It is not a big church, a building that we can see, but we keep worshipping in a small group, playing guitar, we keep on spreading the Gospel. So, as time goes by, everything is getting better, the feeling of hatred got better and slowly it has gone.

I have moved to Medan. Still, I love Banda Aceh even if they have done bad things to our church, I still love Aceh. Can you imagine that? In Medan, most of them are Christians, but I don't feel the love, I don't feel the connection in Medan. I still love Aceh. So the hate must be gone. Because most of my friends ... were Acehnese people. They were lovely, they were fine with me. With my faith. It was just a small group of people who did that, that day. Got paid. So, no more hate. I still want to go back to Banda Aceh. I still do.

The incident in Banda Aceh is not an isolated example of a group taking the law into its own hands. In April that same year, the district head in Singkil 
had ordered the closure of 17 Protestant churches, two Catholic churches and one non-denominational church in response to demands made by the FPI. Yet, the history of closure and destruction is marked by events in March 1995, July 1998, September 2001, September 2006, August 2015 and October 2015, and similar incidents have taken place in Aceh involving mosques used by Ahmadiyah, and by Shi'a Muslims in Aceh Selatan and Bireuen (see, e.g., Marshall 2018).

A central government decision applying to the whole of the Indonesian archipelago to form Religious Harmony Forums (Forum Kekurunan Umat Beragama, FKUB) has particularly affected minority groups and groups that lack formal state recognition. The idea was that the forum would take responsibility for granting planning and construction permits for houses of worship, but, as the interviewees in Banda Aceh explained, the regulations have been formed in such a way that, in a place whose neighbourhoods are 98-99\% Muslim, gaining consent for a house of worship for a minority religion has proved impossible. After the 2012 attack, the GBI Banda Aceh changed the location of Sunday sermons to different rented halls across town, but after warnings of an FPI-led attack, Sunday sermons were replaced with small, homebased meetings.

At other times, the military and police protected FPI targets. Once, in 2014, I witnessed an attempted amar ma'ruf nahi mungkar action by the FPI in Peunayong, which was stopped by the military at the bridge entering the neighbourhood. The FPI held a public demonstration in front of the regional police office where some of the participants were detained. The leader of the FPI pleaded for the municipal government to revoke the business permits of any hotels and salons that violated Sharia regulations, and further asked that the Civil Police (Satpol PP) and the Sharia Police (WH) in Banda Aceh should play a more active role in 'preventing immorality'.

\subsection{Bunda's Advice: Paradise Awaits}

On 2 June 2016, a feature film, Surga Menanti (Paradise Awaits) - co-produced by the Sheikh Ali Jabeer Foundation and Khanza Film Production - was released at the XXI Epicentrum movie theatre in Jakarta and 40 other cinemas across Indonesia, just two weeks before the fasting month of Ramadan (Serambi Indonesia 2016a). The film narrates the story of a young Daffa (played by Syakir Daulay) who aspires, with the support of his parents Joseph (Agus Kuncoro) and Humairoh (Umi Pipik), to become a Quran reciter/memoriser (Quran hafizh) for which he is schooled at a tahfidz (memorization of the Quran) boarding school headed by Kyai Sula (played by Muhammad Syakir Sula) and ustadzah (female religious teacher/scholar) Rumaisha (played by Astri Ivo). Not even the distance of the school from home is an obstacle for the 
parents or their son in pursuing his dreams. Just when his dreams were about to come true, however, his mother is diagnosed with leukaemia and his father asks him to return home. Despite these challenges, both parents encourage their son to continue his efforts to reach his dream.

The film attracted Acehnese media attention because part of it had been filmed in various locations in Banda Aceh, including the Baiturrahman Mosque, the Tsunami Museum, the Islamic State University Ar-Raniry campus, and Ulee Lhee beach. Interest intensified due to the slowly accelerating campaigning ahead of the mayoral and governor elections in April 2017. The mayor in office and PPP candidate, Illiza Saaduddin Djamal, appears in the film in the role of a female religious leader, ustadzah Rumaisha, wife of Kyai Sula, and also sings the main theme song of the film, Nasihat bunda (Mother's advice), with social media even nicknaming her 'Bunda' later on. The municipality website published a locally edited version of the film poster where Illiza is added into the portrait of the main characters (Image 3). In the following section, the video and song lyrics are reconstructed to augment this chapter's discussion of female Islamic respectability, notions of pious self-governance and ideals of the kota madani. The YouTube video ${ }^{14}$ release of the song is a 'behind-the-scenes' compilation published by the PR team of the Banda Aceh municipal government (Humas Pemko Banda Aceh, 26 May 2016).

\section{Nasihat bunda - Mother's advice ${ }^{15}$}

The video starts with a scene where Illiza, ustadzah Rumaisha, is standing in the university grounds, talking to a male student and non-verbally showing caring affection by touching him on the arm. It cuts to a group of three female students who are admiring the male student and giggling with one another. The wider set-up of the scene is then revealed, with the film crew guiding locally recruited student extras around the campus. When Illiza sings the first line of the song, 'Listen my child dear', the video cuts to a studio set-up showing Illiza wearing a headset, reading the lyrics and singing into a microphone.
Mother's advice for your life-
Later, when we separate,
Don't forget your mother in your prayers.
My child's life is like a dream.

The video cuts to a collage of film scenes, including several vignettes of family disputes and quarrelling, breaking the news of Daffa's mother's illness, an image of the boarding school headmaster, Kyai Sula, and the boy's mother, Humairoh, who sits in a Quran reading group overlooking mountainous views and their home town. The collage is accompanied by the following lyrics: 


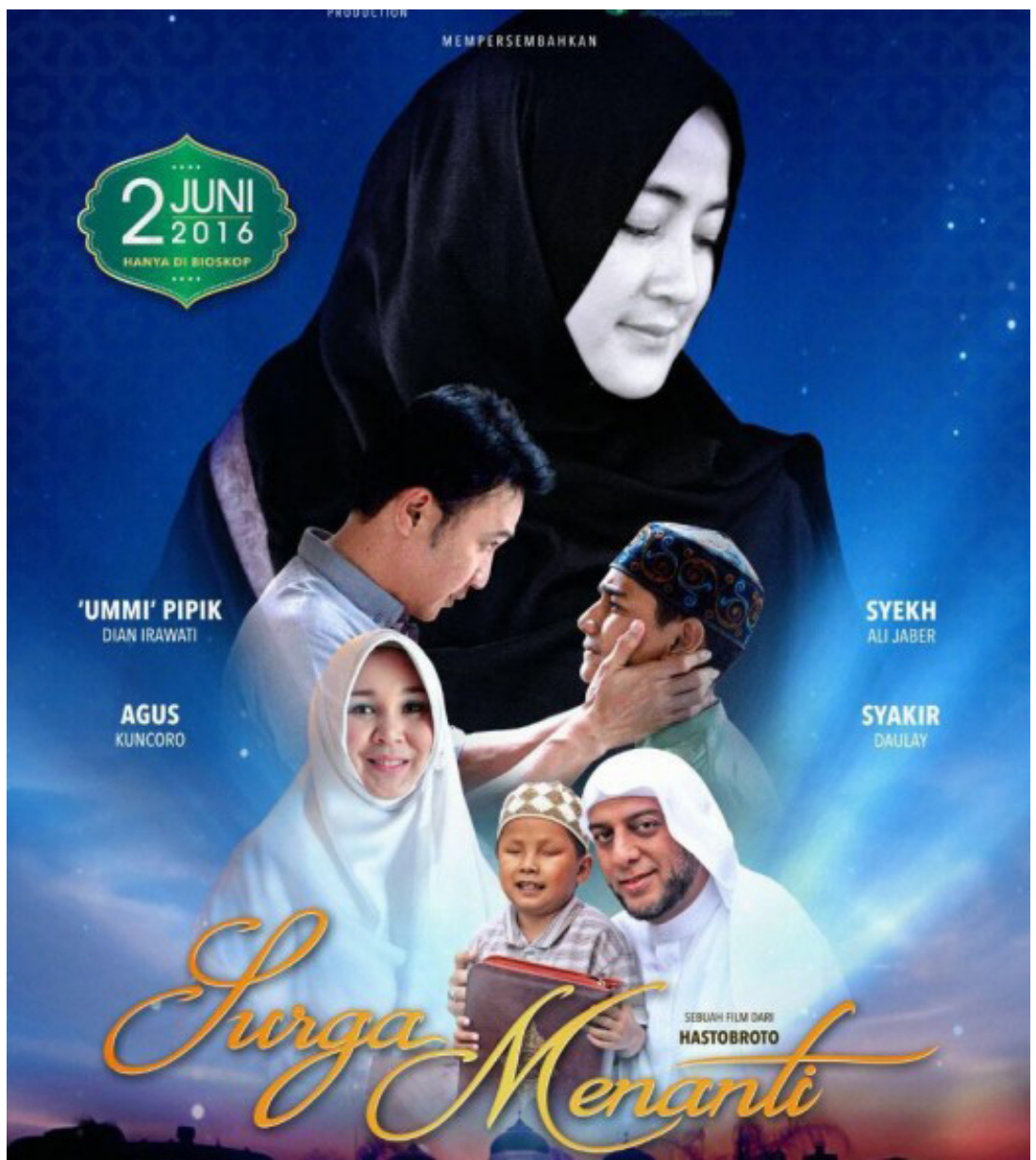

Image 3: Film poster with Illiza.

Source: Anterokini.com.

Do not be swayed immediately awake,

Don't get me wrong, my dear loved one.

Walk on this earth,

Languish later on yaumil mahsyar. ${ }^{16}$

The video cuts back to the studio, where Illiza sings, looking into the camera:

Follow the commands of Allah and the prophet,

Do not do evil deeds,

My fellow human beings. 
Please help, oh my dear,

Later paradise awaits.

The camera moves to a mountainous scene, where Daffa's mother Humairoh is praying while her husband Joseph watches her; they look sadly at each other as she weeps. The video cuts to a film scene where the father Joseph is being driven in the back of a lorry to a hospital, and then back to studio where Illiza is singing:

My child's life is like a dream.

Do not be swayed immediately awake,

Don't get me wrong my dear loved one.

The video moves to a boy during a prayer call, reciting Quran; then there is a temporal shift to the same boy later crying at the hospital after his return home, together with his mother, while Illiza sings,

Walk on this earth,

Languish later on yaumil mahsyar.

Daffa cuts his praying short and forcefully closes the Quran and the video returns to the studio and Illiza:

Follow the commands of Allah and the prophet.

She turns to look at the camera, and the viewer:

Do not do evil deeds,

My fellow human beings.

The camera gives an overview of the town, while the mother, in tears, writes a letter to her son.

Please help, oh my dear,

Later heaven awaits.

During the last line of the song, the video returns to the studio, where Illiza sings while gazing into the camera and smiling. There is a brief clip of Daffa talking to his father, and then back to the studio where Illiza sings:

Love each other, heaven will wait later.

The video cuts back to the film and a scene in the intensive care hospital room, where tears are falling from the mother's eyes and father and son are 
talking in the background, then returns to the studio where Illiza is smiling. In the final scene of the video, the father hugs his son as they overlook the town below.

Just before the release of the film, Serambi Indonesia reported that the song was composed by Illiza's niece, Rara Tarmizi, daughter of Ir Tarmizi A. Karim, a well-known political leader (head of district, bureaucrat in the governor's office), and that important scenes of the film were shot in the city of Banda Aceh, as well as Wonosobo, Cirebon and dan Beijing (Serambi Indonesia 2016d). As already mentioned, the Banda Aceh locations are an intimate part of the visuality and locality of the post-tsunami, reconstructed city: the Baiturrahman Mosque, the Tsunami Museum, Ulee Lheue beach/port and the Islamic State University Ar-Raniry campus. In the making of the film video, the only recognisably 'real location' of Banda Aceh used is the university campus, whereas the other scenes are from the final film locations.

The focus of the municipal government's PR office's press release from April 2016, titled 'Paradise awaits in Banda Aceh', is on the Islamic ideals that Mayor Illiza wants to convey with the film, narrated as a meeting between the mayor and the film's production team in her residence in Banda Aceh:

The film may become syiar da'wa (great da'wa) and a source of motivation for the younger generation to love the afterlife more than the world they live in. This is one of our da'wa efforts that strive to improve human qualities. The key to solving today's social problems is the strict, full enforcement of the Islamic Sharia. This film tells the story of young people, the hope of the nation, young people who choose the path of Allah SWT and emulate the life of the Prophet Muhammad.

Illiza also hopes that, through this film, the city of Banda Aceh [will be seen as] safe and comfortable after both the conflict and the 2004 earthquake/tsunami disaster, [and this] will be increasingly echoed throughout the world. 'Thank you to all those who have helped us since the rehabilitation and reconstruction period so that Banda Aceh can now rise again.'

Pemerintah Kota Banda Aceh 2016

Thus, both the film and the theme song 'Bunda's advice' connect constructed film reality to the struggles and aspirations for the kota madani.

As this short sample of film production illustrates, active use of social media and visibility in popular culture such as films lie at the core of Illiza's role as vice-mayor and later mayor, and head of the United Development Party in Banda Aceh. It can be seen as an attempt to balance 'Islamic piety populism' and female leadership, and materialising her dream of the civilised city (kota madani), while actively promoting the Arabic concept of madani, which 
references the city-state of Medina and Muhammad's role in building the city after departing from Mecca in the 7th century.

In Acehnese media, Illiza's film role was described as 'not different from the female leadership role [mayor] that she currently nurtures. ${ }^{17}$ Illiza herself explained that, "We want to show to the world that although we impose Islamic law, it does not mean we should not have or we should avoid entertainment' (Serambi Indonesia 2016b), and that the film promotes Aceh and shows the world it has been rebuilt since the tsunami and armed conflict as safe and newly risen (ibid.). For the purposes of local promotion, the tailor-made posters mentioned above appeared in social media, with Illiza added in. Earlier research on the Indonesian film industry, religiosity and gender in popular culture suggests that such films form an important arena where ideas about Islam are constituted and contested ... not what Islam is, but rather what Islam could be and should be' (Hoesterey and Clark 2012, 208 emphasis in the original), meanwhile noting that characters, conflicts and lessons are aesthetic choices, but also theological arguments and political positions (ibid.). Illiza's appearance as an important moral and pious protagonist in the film supports her proselytising attempts as mayor of the city of Banda Aceh, her role in supporting the growth of the city as the kota madani and full implementation of Sharia Islam, while - more importantly perhaps - giving guidance for the self-governance of its citizens in ways of pious subjectivity. This role as a female religious leader in a film also suits Illiza as the daughter of the headmaster of an important Islamic boarding school, and head of the Banda Acehnese section of the PPP, in which her family has for decades had an important position, even during the conflict. After unsuccessfully campaigning for re-election as mayor in 2017, Illiza successfully campaigned for a position in the 2019 People Representative Council (Dewan Perwakilan Rakyat, DPR), with nearly 32,000 votes.

The local media in Aceh is known for being close to the municipal government's PR staff, an affiliation in which globally connected media networks form an integral part (examples are given in Chapters 5 and 6). Media reportage of events and leaders' statements, English-speaking international media included, forms a discursive layer in which the ideals of 'better Aceh' are constantly negotiated. In fact, Mayor Illiza admitted in my interview with her that she is well aware that the Western media use anecdotes from Aceh for Islamophobic and Eurocentric purposes. To add another discursive layer, however, her own public appearances and active use of populism deploy the stereotypical views of Western/European media and understanding of Islam to construct an Acehnese Islamic perspective and appreciation of this as a 'nonWestern' constellation.

I interviewed Illiza in 2012, just after her successful election campaign to become vice-mayor of the city, and her whole election team (tim sukses) was keen to underline how female voters made the difference which helped the mayoral candidate pair, Mawardi-Illiza; during the first election campaign, 
the major women's organisations supported her candidacy. Further, Illiza had been rewarded during the reconstruction years with a gender award by the German development aid agency, GTZ, after which she developed the campaign to build Banda Aceh into a 'gender-friendly city' (kota ramah gender), a concept that was introduced after the Habitat II Conference, Istanbul Cities Summit, in 1995. In Banda Aceh, with the support of mayoral leadership, women activists and organisations, and international aid agencies, this involved holding separate women's budgetary planning meetings (musrena) before the formal musrenbang meetings (citizens' participation in development planning), committing to increasing the municipal budget allocation for women's empowerment (from $0.11 \%$ to $5 \%$ ) and specifically focusing on allowing better access to microcredit schemes (see, e.g., Srimulyani et al. 2018). These acts can be seen as part of an increased gender sensitising of reconstruction efforts in Aceh, as discussed in my earlier work (Jauhola 2013; Daly et al. 2016).

In later interviews with some women's rights activists, however, they explained that their image of her had changed from a role model to that of a religious ideologist; they also observed that her active promotion of conservative, gendered piety had increased her popularity among the more conservative Islamic groups, such as the FPI and HTI, organisations that could benefit from collaboration with conservative female leaders when pushing their own agendas. Often, such conservative organisations deny women's right to hold leadership positions, yet, in the case of Illiza and a few other strong female leaders, they had made an exception to their hard rhetoric. The connections between conservative female leaders and hardliner Islamic organisations, and the role played by formal government structures - such as the forum established for the dialogue between the formally accepted religions - became a topic of acute discussion in relation to attacks on churches (see above), as these issues problematised the loyalty and solidarity of feminists in the face of the agendas of politically active women.

Illiza's 2017 campaign illustrated that the fine balancing act between being a pious woman, public intellectual and successful politician, while cooperating with conservative religious forces, can be challenged. Her candidacy, which did not lead to re-election, was heavily criticised by conservative Muslim leaders' promotion of the notion that in Islam, women cannot lead the country nor the people. Nonetheless, Illiza continues on her da'wa mission. In a recent 2019 interview by Serambi Indonesia, Illiza's stated dream was to set up an 'Illiza Centre', a da'wa centre that would support her goal of encouraging religious growth and strengthen her community service role. The article, titled 'Between career and family, focuses on the positive role offered by Illiza to Acehnese women, who, she hopes, will develop the ability to strive for successful careers in the future. Analysing the article as the public construction of a new ideal of Acehnese womanhood, it is a story of a woman with strong political and religious connectivity and an elite background that facilitates the successful, concurrent performance of the roles of good wife, mother and politician - but 
also the story of an actively practising Muslim, who sees her role as a provider of $d a^{\prime} w a$, religious education. 'If I have free time I like to cook [laughter]; cooking is my hobby. I also like to read the Quran. Every day I like to read. Those are my happiest moments, when I have time for introspection [muhasabah diri] because, indeed, every day there are many things that are wasted in vain.' She made a point, throughout the interview, of emphasising that she is a truly feminine woman, who likes to cook and sew; yet she also clarifies that she does not agree that women are only capable in the domestic sphere or that women workers are 'second class citizens' (Serambi Indonesia 2019a).

The next section follows Illiza - first as vice-mayor, later as mayor - through Banda Aceh-based events, including motivational speeches given to government-sponsored women's organisations and when guiding the city's young adults and adolescents onto the right path. The focus here is on the 'positive' image of the pious new woman, whereas Chapters 5 and 6 address Illiza's turn towards a more militarised, yet still caring, version of womanhood - which also has its place in Acehnese women's history - when she actively participated in condemning the Acehnese LGBTI community via images of her at a shooting range which circulated in social media.

\subsection{Guidance towards Ideal Womanhood through State Structures}

My formal interview with Vice-Mayor Illiza in September 2012 was cut short as she had other meetings and events to attend to at the time. I then walked downstairs from her upper-floor office and joined the event being held in the yard of the municipal government building: a cooking competition using 'all in fish' with 3Bs (Beragam, Bergizi, Berimbang dan aman) - namely, producing meals that were diverse, nutritious, balanced and safe, while increasing the diversity of cuisine based on local resources. It was an event organised by the Family Welfare Programme (Pemberdayan Kejahteraan Keluarga, PKK) of Banda Aceh, chaired by the wife of Mayor Mawardy, Ir Nurshanti, and also hosting the head of the Office for the Empowerment of Women and Protection of Children (Badan Pemberdayaan Perempuan dan Perlindungan Anak, BPPPA), Badurisa. These two organisations form the backbone of the government's formal infrastructure for women's empowerment. With an important history since the New Order period, ranging from central government to village level, the PKK was established in the 1970s by the Minister of Interior to promote the formal state ideology of the 'five duties of women' (Panca Dharma Wanita): to be loyal companions to their husbands; to procreate for the nation; to educate and guide their children; to regulate the household; and to be useful members of society (Wieringa 1992; Robinson 1995; Rinaldo 2002; Blackburn 2004b; Jauhola 2013). The BPPPA, formerly known as the BPP (Biro Pemberdayaan Perempuan - Agency for Women's Empowerment), has a more recent 
genesis, established after the adoption of the presidential instruction on gender mainstreaming in 2000. Both organisations received significant funding for their activities during the tsunami reconstruction years (Jauhola 2013, 32). In my meetings with PKK members in 2012, it became clear that, whereas elsewhere in Indonesia such institutions, in particular the PKK, had been functional and active since the Suharto years, in Aceh, mainly due to conflict and the locally active resistance to central governance initiatives (discussed further in connection with marriage registration below), this had not been the case. The reactivation was partly a result of international humanitarian intervention, and partly due to the increased interest of Acehnese women in 'localising' the agendas of such organisations to fit the needs of formal implementation of Sharia. Further, although widely recognised by many Acehnese women for their value in creating a space for women's empowerment discussions, these platforms were also criticised in private interviews as representing an understanding of empowerment based on the patriarchal system.

The event started formally when Vice-Mayor Illiza arrived, first shaking the hands of the seated women in the audience, then moving forward with the selected jury to judge the menus of the competitors, representing the PKK's neighbourhood committees, who had qualified from the semi-finals. Thus, the event was attended by the top leaders of the city's formal women's organisations, as well as Vice-Mayor Illiza, as Mayor Mawardi (husband of the main organiser, the head of Banda Aceh PKK) was unable to attend due to other engagements. This representation by the mayoral office is relevant because, at a time when female leadership roles in government institutions were rare, the wives were ranked in their own organisational PKK structures according to their husband's rank in the government. Illiza's appointment as the vice-mayor, therefore, created another type of position, which can be seen as challenging the wives' organisations' mandates and even create a competitive agenda; it also, importantly, suggested the possibility of coalitions and greater visibility for upper-middle-class or elite women in the city. The hired MC at the competition, when formally opening the event, humorously asked whether it was now time for the seating arrangements to be reorganised in accordance with the regulations of Sharia law, requiring the separation of the two sexes. A moment of ordering the space followed, allowing the media and the municipality's PR office to go ahead with documenting the event with still photos and video recordings.

Watching video footage of the event, and the aesthetics of the competing teams, draws attention to the upper-middle classness of the event or, at least, illustrates such ideals: the participants are dressed in chiffon and use a range of plastic utensils (Image 4), some of which are very specifically designed for the preparation of special dishes like mashed fish cakes - reflecting, for example, the Tupperware sales exhibition at Taman Sari Park at around the same time.

Moreover, the notion of ideal 'housewives' was, at this particular event, connected to that of transferring knowledge of the $3 \mathrm{~B}$ - diverse, nutritious, balanced 


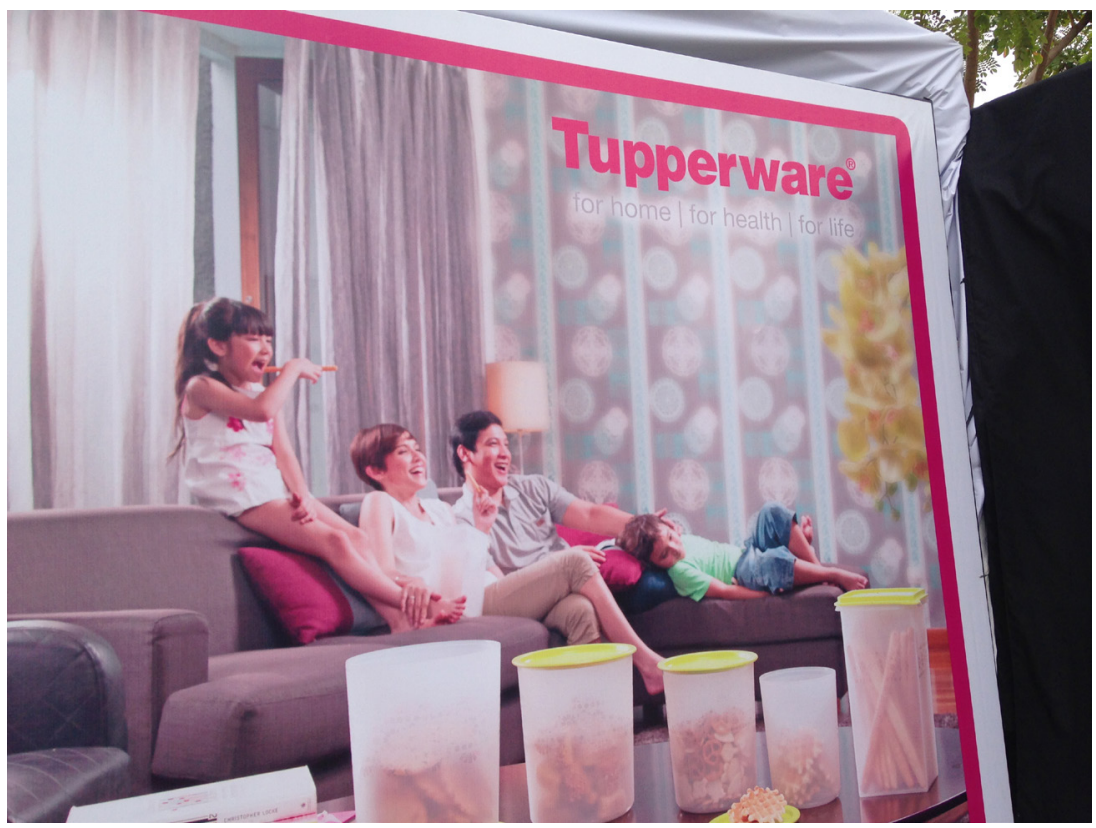

Image 4: Tupperware sales exhibition at Taman Sari.

Source: Marjaana Jauhola.

food - a task that had typically formed a central part of the PKK's legacy since the New Order period. This time, however, the emphasis was on locally available raw materials, specifically fish, thereby connecting ideal wifehood to support of the local economy in an increasingly global and certainly Indian-Ocean-wide political economy of raw food ingredients, against the backdrop of the dominance of non-Acehnese food items in middle-class supermarkets in Aceh.

These same elite women would often attend the main events organised by the city and ensure visual documentation of them in social media with mobile phones and tablets. Ethnographically, such events - and particularly their commencement and closing formalities - created opportunities to observe the stretching and bending of formal roles and hierarchies. Furthermore, after the formal events were over and government officials (often men) and media had left the scene, there was an opportunity to observe the women enjoying the female-only space for their recreation: singing karaoke and dancing. This would sometimes last hours, and was also evident at the residence of the vicemayor after the event she organised for female pilgrims preparing for their Hajj.

I arrived at the Hajj event a little late, but heard the formal speech by an ulama, prayers and the traditional Acehnese blessing of the pilgrims, followed by a buffet lunch, and the finale of karaoke and dancing, and relaxing in the more private part of the vice-mayor's residence (Pendopo wali kota). The residence 


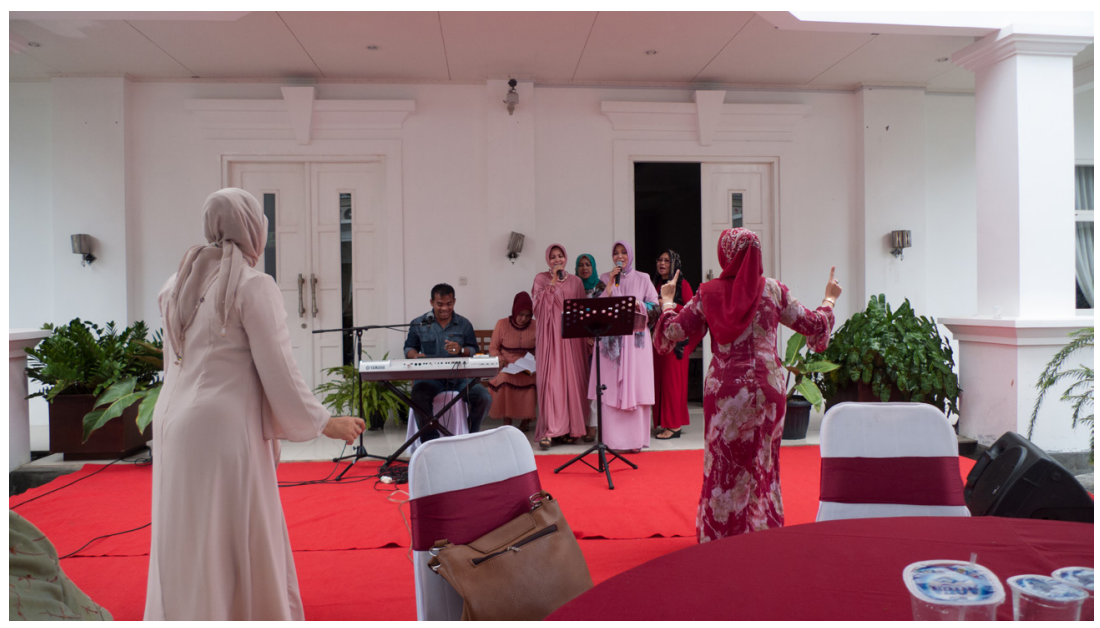

Image 5: Hajj event - dance/karaoke.

Source: Marjaana Jauhola.

resembles other colonial-period buildings in Banda Aceh, with a massive and elegant drive-in entrance to a white building, in which an inner courtyard separates the public function area from the more private living quarters. After the formal 'Islamic part' was over, the music system played some of the biggest hits of the 1980s, such as George Michael's 'Careless Whisper', to which the women who stayed on were singing and dancing (Image 5). My attempts to talk 'business' did not go down very well; rather, skills in karaoke singing would have been of more use that evening. The willingness to share this part of the event with a stranger impressed me, however: copies of (and even genuine) designer bags, designer scarfs, jewellery and all manner of feminine luxuries were on display, emphasising the guests' class and social status. A careful shifting from the public sphere to a more private one when the formal elements were over and the 'masses' had left also provided an opportunity to engage in joyful and relaxed forms of sociality and togetherness: dancing, letting go of the jilbab, teaching dance moves to others and taking part in joint singing sessions of well-known romantic songs.

\subsection{Contestation of the Public Sphere and Islamic Women's Respectability}

This section provides an overview of two other types of public sphere contestation that take a slightly different form from Illiza's or even the PKK's activities in urban Banda Aceh. I focus on two campaigns that took place at the same time in early March 2015 as combined demonstrations that marched across the city, and two social media campaigns: the Acehnese women's 
organisations' initiative on International Women's Day (for earlier analysis, see Jauhola 2013), and another global campaign, 'Women and Shariah': separating facts from fiction', organised by Hizbut Tahrir (HT) and locally led by the Acehnese leaders of Hizbullah Tahrir Indonesia (HTI). What follows draws primarily on screen-captures made of the openly accessible social media material from different organisations' Facebook pages: namely, those of Solidaritas Perempuan Aceh, Balai Syarah, HTI's pages Aceh for Khilafat, and the Women and Shariah campaign page administered by the media department of the central HT office. ${ }^{18}$ What emerges as rather interesting is that, despite being strategically positioned as opposites (Islamism vs. secularism), the campaigns also share key elements, such as a critique of capitalist neoliberalism and the oppression of women. Yet, the campaigns offer rather different solutions to the negative impacts of globalisation and, thus, can be seen to struggle over space in the making of post-conflict and post-tsunami Aceh, and over the ideals of its citizenry. Both of these campaigns aim to attract the general public - that is, can be seen to be "semi-populist" - but both also share the idea that change happens not only through the mobilisation of the public 'we'; it must also influence political and religious elites. Just like the international, national and local promoters of gender equality and UN Security Council Resolution 1325 (Jauhola 2013), HTI had gained its visibility in Aceh in the aftermath of the tsunami (Nurdin 2015). Thus, the counter-discourse on gender can be seen as a direct result of the public politicisation of gender ideology in Aceh, alongside local and international attempts to accommodate secular and Islamic feminist ideas on gender equality (Jauhola 2013; Daly et al. 2016).

Hizbut Tahrir, established in Jerusalem in 1953, aimed to restore the 'caliphate' lost when Ataturk officially ended the Ottoman Empire in 1924. Over the last 70 years, the movement has become global, operating in five continents with the aim of 'caliphisation': the reunification of Islam globally through the re-establishment of a worldwide caliphate (Nurdin 2015, 76). HTI emerged formally in the post-Suharto era in 2000, although its roots go back much further to when it started clandestine mobilisation at grass-roots levels during Suharto's New Order. In Aceh, the organisation was established rather quietly in West Aceh in the early 2000s, but it was in the aftermath of the tsunami that the organisation saw its opportunity to engage in post-tsunami rehabilitation and a simultaneous, or rather, integrated form of $d a$ 'wa or proselytisation to 'proximate others' (ibid., 76) - that is, Acehnese known to be devout Muslims (for detailed analysis of the strategies used, see Nurdin 2015). From the reconstruction years until it was banned in Indonesia in 2017, HTI increased its visibility in the public sphere, beginning with its first stage of tastqif, or disseminating its culture. It then moved onto the second stage, tafa'ul ma'a alummah, or interaction with the wider society through study circles, while also reaching out to wider Islamic ummah (tsaqafah jama'iyah) and taking part in public debates (shira' al-fikri) to contest and overthrow ideologies that are incompatible with Islam, such as capitalism, feminism, communism, socialism, 
imperialism and kufur (infidels) (ibid., 82-83). Despite gaining greater visibility in Aceh, membership of the organisation remained low, although it seems to have created grassroots networks and connected with influential individuals who regarded themselves as spokespersons for the global khilafah, or caliphate.

Thus, the campaign discussed here, Women and Shariah, exemplifies a global campaign, led by the central media unit of the HT, which chose to spread the conference out over five simultaneous locations: Palestine, Turkey, Indonesia (Aceh), Tunisia and the UK in 2015 (Hizb ut Tahrir 2015). The 2016 and 2018 campaigns - with no formal reference to HT, as it had been made illegal in Indonesia - specifically focused on the issues of LGBTI, liberal feminism and CEDAW as un-Islamic (for details of the LGBTI campaign, see Chapter 6).

Locally in Aceh, the organisation behind the February-March 2015 campaign and conference was the Banda Aceh local women's branch of the HTI, clearly supported by the Jakarta-based HTI leadership's use of Aceh as an example of striving towards khilafah. The campaign was launched roughly one month before IWD on 8 March and HTI's own international conference on 7 March. Shortly before, Iffah Ainur Rochmah, Juru Bicara MHTI appeared in a Facebook post with the following quote:

Kilafah Islamiyyah has been proven to embody honour, glory and welfare for women. Even the history of the archipelago which is part of the Ottoman Khilafah has given birth to a golden age for this country. Among them, Acehnese women felt for centuries how the Islamic Sharia glorified them, magnified their gait, and guaranteed their honour.

Aceh Untuk Khilafah Facebook page, 13 February 2015

The post included a longer educative text that focused on detailing the benefits of the implementation of Sharia for the progress and well-being of women, responding to the challenges faced by Muslim women in the process of globalisation, ${ }^{19}$ and contextualising the need for the campaign to address misconceptions about Sharia. The latter specifically targeted the Indonesian state and the false accusations that the existing 342 local regulations directly concerning women (Islamic dress, prostitution, pornography and segregation in the public sphere), and those that regulate khalwat, mesum (immorality) and jam malam (curfew), discriminate against women.

The campaign suggests that these false accusations give rise to Islamophobia and result in people abandoning Sharia as guidance in their lives because they address the question of Sharia and women from the perspective of human rights or ideologies such as democracy, which position God/Allah and the ideology of Islam as subordinate. The task is, therefore, to return the question of women to outside the context of the secular state and its political economy, and recentre Sharia. Addressing all HTI members, the Facebook post uses the specific example of the history of Aceh, making the claim that the close economic and political relations between Ottoman Turkey and the Sultanate of Aceh made 
the Sultanate an integral part of the Ottoman Empire (khilafah Utsmani) (see also Nurdin 2015), bringing a 'golden age' to the nation. This is supported by detailing the satisfaction of Acehnese women with how they were governed by Shari'a and how Shari'a glorified women, ensured their progress and guaranteed their honour. Acehnese heroines, such as Laksamana Hayati and Cut Nyek Dhien, are named as prime examples of women who resisted the Islamophobic image of Acehnese women (see the analysis of the politicised uses of historic figures in Jauhola 2013), and the post ends with the Quranic verse asSaf [61:08]: 'They want to extinguish the light of Allah with their mouths, but Allah will perfect His light, although the disbelievers dislike it.'

The campaign was divided into three thematic and temporal phases (Image 6). Phase 1 aimed at exposing the secular agenda to reform the Islamic social laws related to women as based upon Western ideals of 'gender equality' and 'liberal freedoms', identifying CEDAW, institutions such as the UN and the concept of

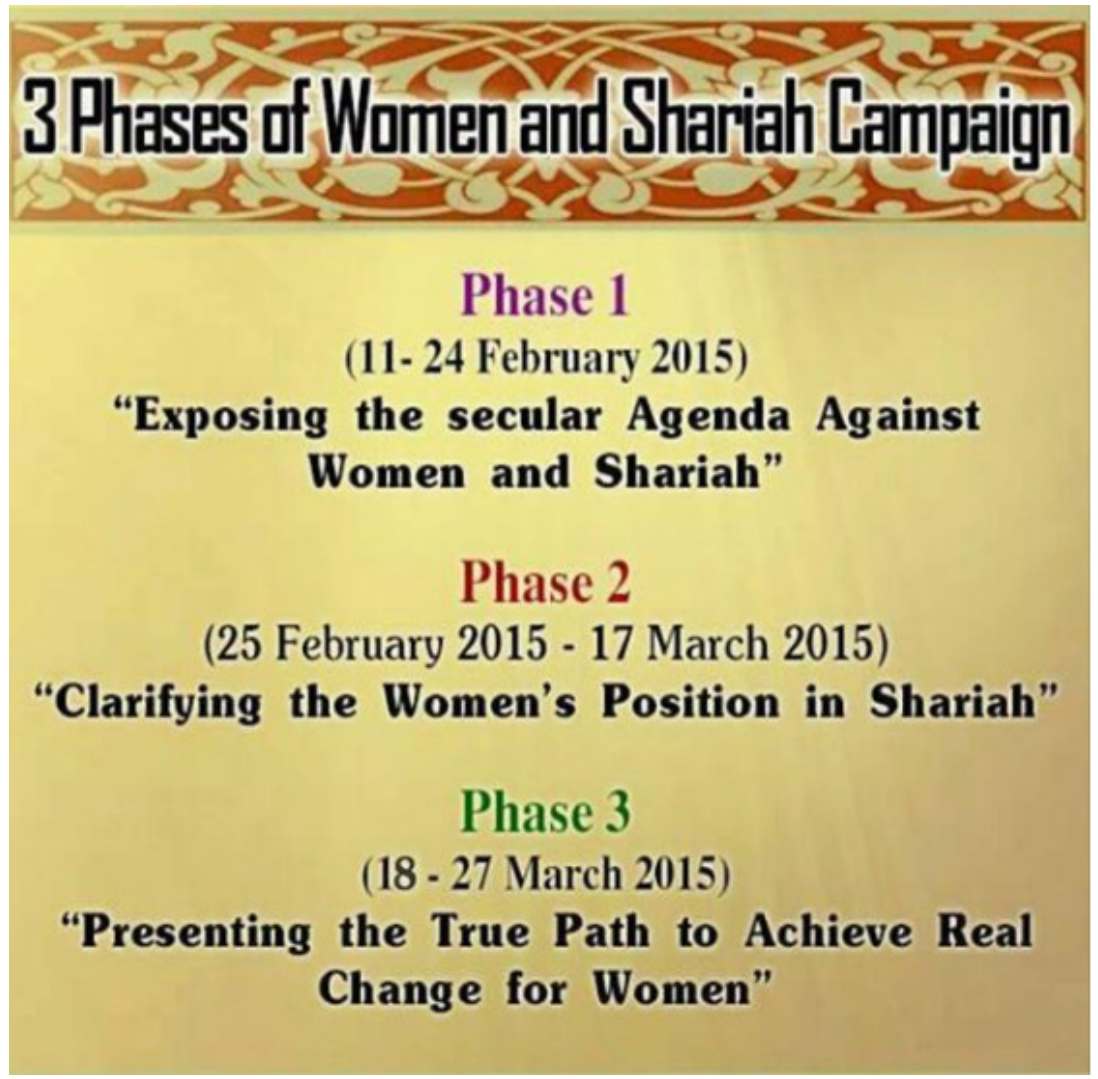

Image 6: HT's Women and Shariah Campaign phases.

Source: Hizbut Tahrir Facebook page, Women and Sharia (@WomenSharia). 
'Islamic feminism' as their focus. The main aim of the campaign was to illustrate how instruments such as CEDAW, as well as the Islamic feminism that has emerged among practising Muslims (Ahmed 1992; see, e.g., Barlas 2002, 2008), contradict the HTI's ideology of what constitutes Islam and the right way of piousness. Thus, interestingly enough, the agenda is not only set to shira' al-fikri (struggle) against non-Muslim ideologies, but also as Nurdin $(2015,76)$ phrases it, to proselytise 'proximate others'. Thus, the public campaign continued the active contestation of gender ideology in Aceh and actively opposed the gender mainstreaming agenda of the Indonesian and Acehnese Governments (for analysis of the reconstruction aid years, see Jauhola 2013). Phase 2 was aimed at clarifying women's position in Shari'a and phase 3 at 'presenting the true path to achieve real change for women'.

In the weeks before the conference, the local organisers in Banda Aceh arranged pre-conference talk shows and seminars and a formal visit to the office of the Bureau for Women's Empowerment and Child Protection in Banda Aceh. They visited the governor's wife, where they invited the formal structures of 'gender machinery' in Aceh (Jauhola 2013) and the government's development planning officials (such as kesbangpol, the political office of the provincial government) to take part in the conference; they also advertised their events with campus groups such as that at the Universitas Syiah Kuala in Banda Aceh. All this was carefully documented and advertised on the Aceh Untuk Khilafah Facebook page, which also included full documentation of proceedings of the main conference. Those materials make the vibrancy of female Islamic leadership in Aceh very evident and also clarify that HTI's strategy of networking with other (Islamic) organisations, politicians and bureaucrats (Osman and Nawab 2010, 613-614) had the aim of influencing and taking an active part in how the agenda of 'empowering women' was to be framed in Aceh, and in Banda Aceh.

Banda Aceh was chosen by central HTI as one of the five locations of the conference on 7 March 2015, which was organised at the Universitas Syiah Kuala. The event consisted of talks and prayers offered by Acehnese female religious leaders, the HTI's Indonesian leader of the women's wing (Mash'ullah Ammah), a member of the central executive council of HTI, Ishmah Cholil, and a musical poetry recital 'Prahara Tanoh Rencong' ('The Tempest of Tanoh Rencong'), ${ }^{20}$ which poetically situated the history of the Sultanate of Aceh as an integral part of the lost caliphate (Ottoman Empire):

Aceh, the land of the rencong knife, carved out history

That never disappeared despite the passing of time.

It is still cherished in my memory,

The peak of the glory of Aceh in the past.

During those days, no one suffered;

All people lived safe and prosperous lives

Under the auspices of the Islamic Shariah. 


\author{
Subhnallah ... \\ Truly, the application of Islamic Shariah brought glory to Aceh. \\ Application of Shariah was guarded, and \\ There was not a single deviation from the law. \\ I asked how this was possible... \\ I sought the answer by following \\ The alleys of history that had been closed. \\ I opened and explored the alleys \\ Until I found evidence that \\ Aceh was part of the Ottoman Empire.
}

The poem then narrates how the caliphate, particularly the pilgrimage route to Mecca, was attacked by the Portuguese, and how after gaining military assistance from Ottoman Turkey, Aceh was feared by the Dutch. It then continues to explain how the Dutch, attempting to destroy Aceh, sent out Dutch anthropologist, Snouck Hurgronje, who pretended to be a cleric and gained influence among the Acehnese clerics, although his thoughts were not based on Islamic aqidah (belief). This part of the poem makes an important claim, saying that syncretic cultural and Islamic practice in Aceh, which combines Islamic and Acehnese cultural traditions with influences from other sources, is no longer the pure Islam of the Quran and Sunnah.
My rencong my rencong,
The land of the rencong knife is not what it used to be.
In the past men woke up to their qawaman
Respectable mothers became their position
Children were filled with joy:
A safe and secure nation with piety everywhere.
I feel the earth has turned upside-down
Dropping me from on high.

The poem then goes on to describe the devastated state of affairs; the poison of women's empowerment has damaged the thoughts of Acehnese women, they want to be like men and they want to close their eyes so that not even religious clerics ( $k i a i)$ can halt their false steps. Thousands of demands have taken women away from their children, and they have forgotten their devotion to their husbands, increasingly abandoning them.

The poetic narration of loss and absence corresponds with the other campaign materials that were distributed in both English and Indonesian on the Facebook pages (for earlier analysis of the politics of humanitarian aid language in Aceh, see Jauhola 2013), openly criticising, for example, feminist strategy such as 'empowerment through employment', which is described as 'a capitalist 
and feminist lie that has cheated women of motherhood, robbed children of their rights and had heavy costs on the wellbeing of women', quoting Dr Nazreen Nawaz, the head of the women's section of HTI's central media office. The podcast interview with Nawaz and the campaign's top messages were later aired in Indonesian on the RRI Pro 2 FM radio station in Banda Aceh. HTI actively reinterprets the history and cultural significance of Aceh by referring to the Turkish Caliphate, and the dream of reuniting Muslims under a new one. Their take on Aceh's sovereign status, therefore, differs from that of GAM leadership and its founder, Hasan di Tiro, who stated in the 'Declaration of Independence of Acheh - Sumatra' on 4 December 1976, 'Our fatherland, Acheh, Sumatra, had always been a free and independent sovereign State since the world began', despite suggesting that the best form of statehood for Aceh would be a sultanate (Abdulah 2018, 48).

Meanwhile, Acehnese women's organisations labelled as secular or humanrights-driven (Jauhola 2013) gathered on 8 March 2015, with the support of international partners such as WLUML, ${ }^{21}$ to celebrate International Women's Day (for previous analysis of IWD celebrations in Aceh, see Jauhola 2013) in Blang Padang. This is a field formally possessed by the Indonesian army, but increasingly used for events and sports, and has an evening entertainment area with food outlets and children's playgrounds. The 2015 march was entitled, 'Peaceful women in diversity without violence. For public intellectuals, especially women, to take part in discussing the elements, relevance and interpretations of what Sharia Islam's gender ideology in Aceh should entail can be seen as an indirect response to the diminishing public sphere in Aceh. Participants dressed in colourful outfits, sang and performed theatrical plays, many carrying bright banners with messages such as 'Acehnese best wishes', 'great women', 'female leader, yes!', which those present could photograph and share on social media. The wider transnational frame, the history of IWD, was explained in one of the Facebook posts (Solidaritas Perempuan Aceh, Facebook page, 8 March 2015), which made the socialist history of the day visible, without precisely labelling it as such (for analysis of the disappearance of the socialist feminist movement in Indonesia, see, e.g., Wieringa 2002). Another organisation, Balai Syuara, posted photos of banners making demands such as 'Stop violence in the name of religion', 'Stop corruption because of poverty', 'Stop sexual violence against women' and 'Peacefully embrace togetherness', aiming to draw attention to the violence that had emerged since the formalisation of Sharia law and the increased contestation over public space.

What is interesting about HT's critique of such capitalist forms of feminism is that the overall critique of the capitalist political system (see, e.g., Irkhami 2014) reflects that by Acehnese and Indonesian women's organisations which, since 1997, have addressed the gendered impacts of neoliberal economic reforms in Indonesia. HT differed in its analysis of the remedies, however - an Islamist state rather than reform of the political economy within the current political system - and, further, for purposes of populist outreach, a constructed 
binary was required: the right way of HT, and the wrong way of secular Western feminism and the political status quo (for a similar tactique used during the tsunami reconstruction years, see Jauhola 2013). HTI began to build its core message by condemning 'Western feminism' and by actively retelling an Islamic version of women's rights history. For example, as part of the 'Women and Shari'a' campaign, Dr Nazreen Nawaz suggested that, rather than celebrating July 2015 as the 80th anniversary of the Equal Franchise Act when women gained the same voting rights as men, women should celebrate December 2015 as 1430 years since

Islam gave women the same voting rights as men. While women in Europe chained themselves to railings and went on hunger strikes in order to secure a political voice and educational rights, Islam obliges women to be active politically in society, and Islamic history boasts of thousands of female scholars.

Women and Sharia Facebook page, 16 February 2015

Islamic feminism was then listed in the campaign under 'feminist failures', with Dr Nazreen Nawaz once again explaining:

Undoubtedly, Muslim women have been victims of heinous crimes, such as honour killings and acid burnings. However, Islamic feminism that directs attention away from tribal and traditional customs, the true cause of these atrocities, to Islam, will only serve to prolong the suffering of many women. In addition, although Muslim women have been serious casualties of the economic, cultural and social fall-out of global capitalism, a call for Islamic feminism that involves the interpretation of the Islamic texts from a secular liberal perspective, will simply prove to re-enforce the very values promoted by the capitalist ideology that has caused untold misery for so many.

Women and Sharia Facebook page, 16 February 2015

Here, the target is Islamic feminist practice, which has been a growing field in studies of Islam since the 1980s, but rather than suggested by Nawaz, it is heterogeneous: partly driven by epistemological and ontological theorising emerging from the 'West', but also grounded in Muslim tradition, while critiquing it (Mir-Hosseini and Al-Sharmani 2015).

Finally, whereas sometimes poststructuralist feminists, with their critique of subject and universal womanhood, are therefore blamed for lacking a feminist political agenda, it appears that HTI offers a clear path forward through

... changing the flawed and oppressive non-Islamic political systems and regimes in the region to one that is based upon the correct implementation of the Sharia - which will only be realised under the Khilafah state 
... illustrat[ing] how the Khilafah would practically solve the day to day problems women face in different spheres of life - e.g. violence, lack of access to a political voice, poverty, lack of legal rights, being deprived of justice, poor access to education or healthcare, etc.

Nazreen Nawaz Facebook page, 12 February 2019

Again, the strategy adopted by HTI is that, in order to construct a binary divide between the right and the wrong path, the material does not refer at all to multivoiced feminist scholarship or activism that draws from critical analysis of the political economy, global capitalism and extractivism. This omission silences multi-faceted feminist debates, but its main aim, of course, is to direct the critique towards Muslims who do not share HTI's vision of piety, government and the path towards prosperity and equality.

After the conference, the wider Women and Shariah Campaign continued delivering the message of the right way. HTI social media focus around 2015 also included themes such as violence towards the Rohingya people, while broader street and social media campaigning focused on the political economy and its consequences (such as abortions and promiscuity), specifically addressing criticism of the ASEAN Economic Community, AEC (Masyarakat Ekononomi Asean, MEA). Interestingly, secular women's organisations, such as Solidaritas Perempuan, with a presence in Aceh since the tsunami, presented a similar critique:

MEA is essentially a free market whereby many foreign products enter Indonesia without import duties. This means that foreign producers can compete in Indonesia at lower prices than domestic products.

Representative of the HTI Aceh Rizal Fahmi, Aceh Untuk Khilafah, 16 April 2015

'Facing Free Market Disasters, Indonesian Women Move to Seize Sovereignty': The various schemes mentioned above have usurped women's sovereignty over land and the food management system. Women continue to be marginalised from their sources of life in the village, so that they are often forced to migrate abroad to work with minimal protection. Including the commemoration of December 22, which is a day when women fight for their public space and right to be involved in solving people's challenges and then it has been narrowed [by the government] down to focus on gender stereotypical roles of women. Therefore, on the day of the Indonesian women's movement, women again struggled to seize their sovereignty in the face of a free market disaster.

Solidaritas Perempuan press release, 22 December 2015

In the video, MoU Helsinki: reclaiming back history (see Introduction, Video 3), one section focuses on how Solidaritas Perempuan provided an 
alternative vision for the celebration of Hari Ibu (Mother's Day or Women's Day) on 22 December 2015, one that reclaims history by addressing the AEC as one of the most burning issues of global economic justice and well-being. Thus, in reality, when addressing the neoliberal and global capitalist logic of open markets, these organisations, while differing in perspective and suggested methods to bring about prosperity and equality (secular vs. Islamist state), both actively engage in the public sphere to educate the public about the negative impacts of such trade and economic policies. Meanwhile, they also try to push political and economic leaders to engage with forms of politics that would address specific vulnerabilities and structural violence, such as increased poverty statistics in Aceh, thereby providing a critique of the current status quo.

\subsection{Paradise Awaits, for Whom?}

This chapter has moved around the cityscape of Banda Aceh, identifying a number of active attempts to construct ideals of the city and its citizenry as kota madani, a civilised Islamic city. It started by illustrating the economic impacts of the reconstruction of its one main sites, Taman Sari, or Bustannussalatin, as it is called today. After an overview of the struggle over Aceh's legal framework, the chapter followed contestations over, and articulations of, the civilised Islamic city and enactments of amar ma'ruf nahi mungkar by both the municipal leadership and the Islamic Defenders Front (FPI). The chapter then turned to the specific role played by Mayor Illiza during her term (2012-2017) as a female leader and role model for ideal womanhood through her office and municipal structures. The final section provided a glimpse of the contested public sphere connected with International Women's Day, with its clash between Hizbut Tahrir's global Women and Shariah Campaign and the goal of a transnational caliphate, and local women's organisations' quest for diversity, non-violence and transformation of the political economy. 

CHAPTER 3

\title{
'Because You Are a Woman'
}

\author{
Resisting a Single Story
}

\subsection{Smile that Hides Sorrow?}

In this life we have to smile more often ... because life is full of challenges and obstacles, but everything is about happiness. (Aziza)

Face all the trials with sincerity and a smile ... because God must have another plan behind all this ... (Putri)

\author{
Sorry, darling \\ I wrecked our home \\ to make room in my heart \\ for a true blue marriage \\ Thank you darling, \\ You saved my life \\ back then \\ when the troops searched for me \\ you took a torrent of wounds \\ You were ready to face the guns \\ $\mathrm{Ya}$, what can I say \\ Just thank you, sweetheart
}

And now I will pledge my love to my new woman 


\section{Said that man \\ without words \\ without ears \\ without eyes.}

Ya, that man

Ran off with the funds

That were in my name

\section{Should I say \\ it was a storm, and your address \\ is sadness?}

This chapter and all the life-historical videos produced as part of this urban ethnography are dedicated to the lives and struggles of women who were often labelled by outsiders (neighbours, media, researchers, sometimes even themselves) as 'failed', 'oppressed' or 'resilient'; yet, these are women who, despite discrimination, exploitation and slipping out of the gendered norms governing the notion of a good, respectable, pious woman or 'dutiful wife', are - in the language of 'resilience' - ready to pick up 'life time and again, wherever and whatever state it is to be found' (Bracke 2016, 60).

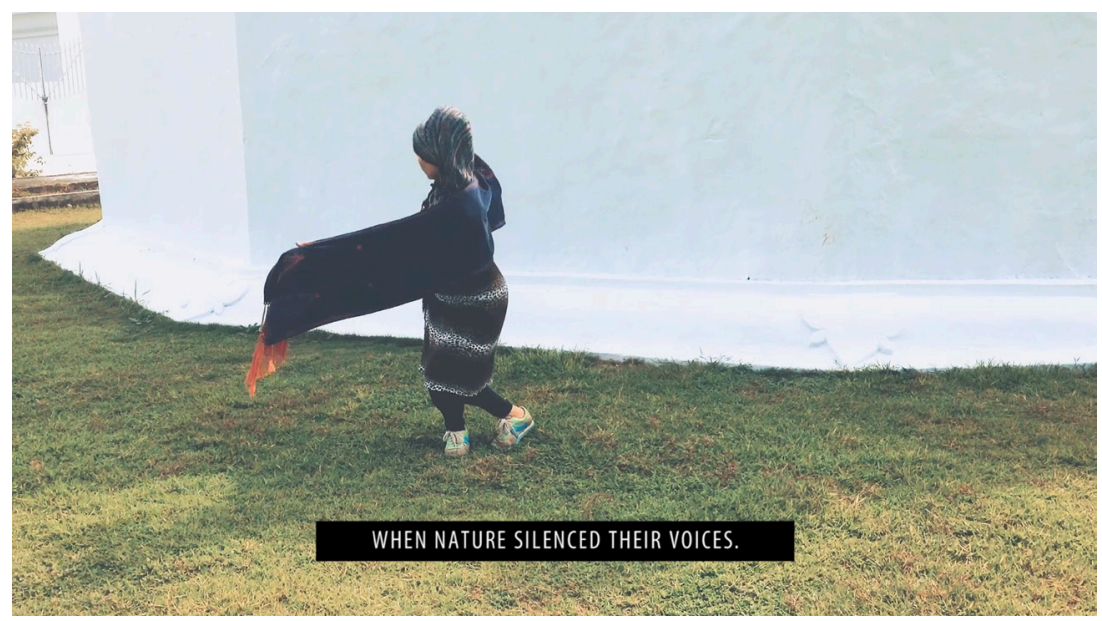

Video 5: Poetic resistance II: because you are a woman (03:20). Source: Scraps of Hope.

To watch this video, scan the QR code with your mobile device or visit DOI: https://doi.org/10.33134/pro-et-contra-1-video-5 
Poetic resistance II: because you are a woman is a poetic dance based on the poem by Zubaidah Djohar, in which she suggests that women's gendered experiences during the armed conflict are both silenced, but also used against women in peace time, to keep them in their place in a patriarchal society.

As Chapter 2 illustrated, gendered norms and expectations of respectability (Skeggs 1997) circulate in the public sphere as part of the wider construction and engineering of the urban space into the 'civilised city', but so, too, do feminist struggles. Meanwhile, as Skeggs $(1997,1)$ puts it, 'respectability is usually the concern of those who are not seen to have it", and for the white feminist gaze, more and more often, these struggles or contestations for respectability form part of what Sarah Bracke $(2016,60)$ calls the 'fetishisation of resilience of the wretched of the earth'

In light of this, how may a Western white researcher write about the experiences of Acehnese women managing their marriage, livelihoods and perceptions of their 'character' or akhlak in a city whose rebuilding also involves attempts to control their story of womanhood, respectability and religiosity? Are they doomed in the construction only to be experiencing horrible things, to be passive victims? Or possibly construed to be in need of white saviourism, subjected to romanticised notions of subaltern resilience or to having their identities singularised around the identity of 'Muslim women'? Is there any other alternative to allowing these pre-imagined representations to emerge? This question, often posed to Western and white (feminist) scholars; is as relevant as it was in 1984 [2003], when Chandra Mohanty addressed the issue of representation of Third World women 'under Western eyes':

I wrote 'Under Western Eyes' to discover and articulate a critique of 'Western feminist' scholarship on Third World women via the discursive colonisation of Third World women's lives and struggles. I also wanted to expose the power-knowledge nexus of feminist cross-cultural scholarship expressed through Eurocentric, falsely universalizing methodologies that serve the narrow self-interest of Western feminism. As well, I thought it crucial to highlight the connection between feminist scholarship and feminist political organizing while drawing attention to the need to examine the 'political implications of our analytic strategies and principles.' I also wanted to chart the location of feminist scholarship within a global political and economic framework dominated by the 'First World.'

Mohanty 2003, 501

This section does not focus on women condemned to caning punishments by the Sharia courts for having violated the laws on opposite sex vicinity or sexual intercourse with a non-married partner, which are visible in the global media narrative and its consumption that feeds Islamophobic notions of white 
saviourism, or simply, white supremacy. Rather, the focus here is on more mundane experiences of slipping out of the boundaries of ideal womanhood constructed through notions of kota madani or management of the self through akhlak, as discussed in Chapter 2, one that is not reducible to these women's own perceptions of their religiosity. The aim in the narration is to show the complexity of lived experience, but also to zoom in on mundane attempts to make life liveable (Butler 2004) and negotiate space within the social networks that are available in Banda Aceh. These efforts may be labelled by outsiders as unfit or dangerous, or as not generating the resilience to produce a figure who shouts at you, the reader, 'Look, I Overcome!' (Bracke 2016, 67).

The stories told below unfold in the varying genres of a dialogue between the researcher and her women interlocutors: ${ }^{1}$ transcriptions from interview recordings and re-narrated glimpses based on research notes. They take place in the short, life-historical videos recorded in different locales in the city, but what is common to them is that they occur in the space of lower-middle classness, aspiring middle classness or economic struggle to regain the status of a middleclass, respectable woman in the eyes of wider society and the neighbourhood in particular.

\subsection{Stranger in Her Own Village ${ }^{2}$}

Smile that hides sorrow tells a story of a single mother whose home garden and knowledge of plants provide both an important escape from the neighbours'

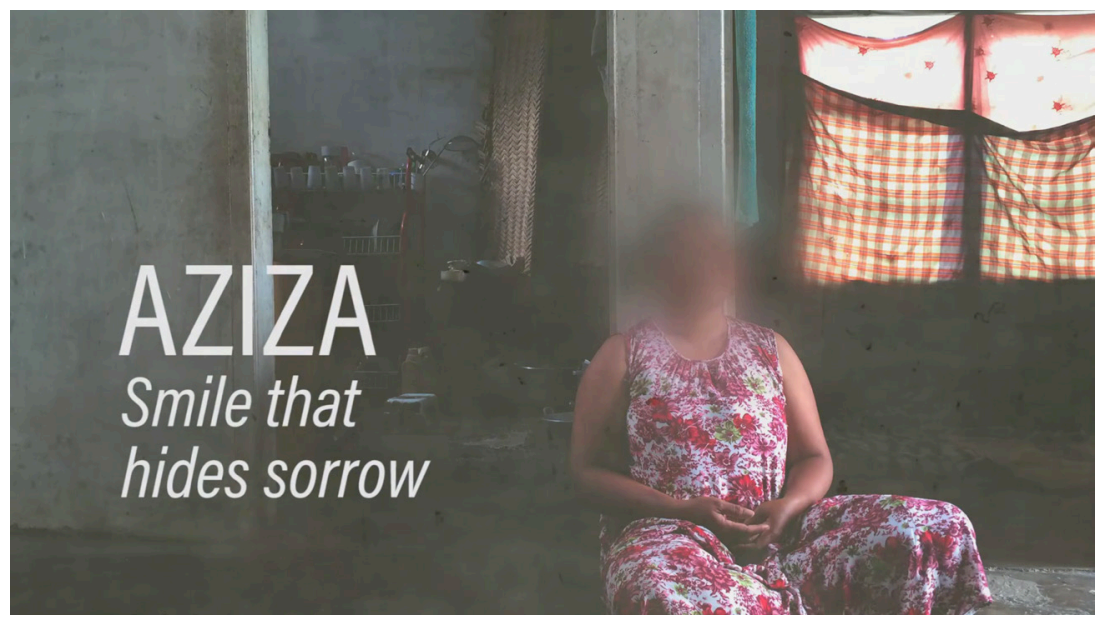

Video 6: Smile that hides sorrow (08:19).

Source: Scraps of Hope.

To watch this video, scan the QR code with your mobile device or visit DOI: https://doi.org/10.33134/pro-et-contra-1-video-6

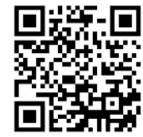


discrimination, but also an important addition to food security and nutrition of her family.

One day, a woman in rubber boots and dirty work uniform calls into the same coffee shop where I usually sit for a coffee break. This is unusual, as the only other Acehnese female customer has been a teenage girl waiting for her boyfriend to finish his work shift in a nearby shop who was later reprimanded by the owner: he does not allow people to commit khalwat sins in his coffee shop. As we engage in conversation, I realise that she is one of my very first research interlocutors, Aziza, with whom I later lost contact. The municipality gardening and cleaning department had transferred her from the municipality nursery to work on the trees and flowers planted on roadsides and intersections and, although she was in charge of the area that was central to my street ethnography, our paths had not crossed again until now.

Aziza is in a hurry to return to work, but invites me to visit her and her family - she is a single head of household with three teenage children - when her afternoon shift is over. Later, making our way to her home, she reveals to me how difficult she finds it to live in a religiously conservative neighbourhood: she is considered dissident, improper and immoral, and her children have shoes thrown at them on their way to and from school. Their neighbour has made sure in every possible way that her family members know they are not welcome in the neighbourhood. Why? Because she has not remarried after the death of her husband, she is not accompanied by a muhrim ${ }^{3}$ when moving around the city and she works outside the house in a male-dominated job. Yet, she has no one to turn to. There are no relatives left after the tsunami.

In fact, our ancestor was not a native from here ... One of my forefathers in my mother's line was from Thailand, whereas my father was Arabic from Bangladesh, my grandmother was from Bangladesh and my grandfather was Arabic. They used to trade here. Aceh was famous for its spices. They lived in this village because it was near the sea, and they were trading spices to Thailand. Then our grandfather settled here, and he brought his whole family here. If you could have seen my mother; she was beautiful, her skin was yellow.

I don't know which part of Thailand; my mother did not tell me. She had closed the case, but I forced her to talk of it before she died and she sat with me and told me part of her story. My mother was brought here, probably when she was still 12 or 14 years old, so she didn't know the location.

Before my mother passed away she said to me, 'Aziza, when I am gone you must learn how to make friends.' Because Mamak was very beautiful and I couldn't believe that she was a native from here, I asked, 'Mamak, where are we originally from?' 'Why?' 'So if you are gone one day, we know where we are originally from.' After that Mamak told me the story. 
Many here are envious of me, because of my unique face. They went to Shamans and asked those Shamans to take away my beauty. People are so envious. They wonder where I got my face from; they do not know my bloodline and family background. They were envious and so did those things to me. I had to cure what they did and now it is better.

Marjaana: Do you think those bad experiences with the villagers here were triggered by the fact that you have a different background, or is it that they cannot accept you for other reasons?

It is just their mindsets. Even though we try very hard to be good, they are always looking for flaws in us ... Sometimes I secretly cry. But not in front of my children. I don't want them to lose their passion for learning because they see their mom crying. So every day I always show them that I am happy, so they do not know what I truly feel inside.

The neighbourhood discrimination has impacted in a number of ways on Aziza's everyday life: physically, mentally, socially and economically. Her house, reconstructed after the tsunami, is located alongside the village road, yet, due to its proximity to the vocally discriminative neighbour opposite, the family never uses the main front door. Instead, what is usually considered a so-called 'back stage' (i.e. back door leading to the toilet/bathroom) became the new entrance to the house, while the front door and the two windows facing the road and the neighbour are blocked with blankets and plywood sheets, making the two rooms facing the road dark; their only access to daylight is the back door that is kept open for that purpose and for ventilation. I was told that this was a strategy to gain distance from the neighbours and block the view into the house from the street.

The dark rooms and blocked windows and front door provide a material anchor to Aziza's feelings of exclusion and discrimination. However, next to her 'new front door' there is a small plot of land where she grows plants and dries fruits in the sun, while the rice field beyond provides landscape views. This is her world and the space that she knows well. Having given up selling fish at the local bus terminal due to a drop in income, she had retrained herself as a gardener. Her knowledge of plants and their healing properties and value is her hidden expertise: she can state exactly the worth of certain seeds and how much they are valued in the Middle East and beyond.

As she struggles to pay the tuition fees of her teenage children, the house remains barely furnished, with concrete floors that are severely damaged after some seven years of usage. Being categorised as a dissident in the village has also meant that the village head has refused to add her name to the list of people eligible for social benefits from the provincial government. Instead, the Islamist Party (PKS), which approached potential voters around upcoming elections, 
included her family as beneficiaries in their monthly social benefit distribution. To secure sufficient monthly earnings, she and her children also produce and package dried potatoes and sweet potatoes in small portions that are then sold in street corner kiosks or by people who trade in public parks and at popular gathering points, such as the Tsunami Museum. One day, she shares with me that she loves volleyball, describing how she used to belong to the provincial volleyball team and how it allowed her to see different parts of the Indonesian archipelago. She wants to pass on this freedom to experience and understand difference to her daughter.

\subsection{Solving Problems Like a Man ${ }^{4}$}

Solving nikah siri - unregistered marriage focuses on unregistered marriage (nikah siri) and polygamy and ways in which the office of women's empowerment mediates a conflict between a wife troubled by her husband's behavior, both of whose lives are marked by the illegal political economy and the traumatic experience of the past armed conflict.

Mariyani, a woman in her 30s and the narrator of the next story, provides entertainment for small children by putting in hours of physical labour, bicycle-powering a merry-go-round. While it now requires heavy maintenance, frequent repair and at times causes several hours of lost income, the machine

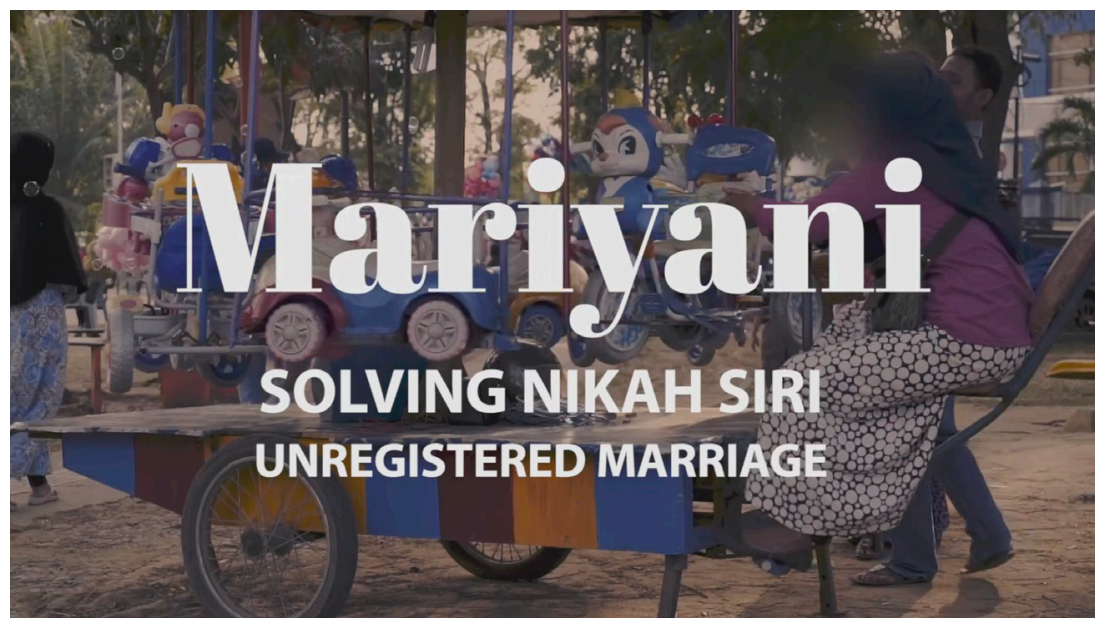

Video 7: Solving nikah siri - unregistered marriage (09:46).

Source: Scraps of Hope.

To watch this video, scan the QR code with your mobile device or visit DOI: https://doi.org/10.33134/pro-et-contra-1-video-7 
was originally supplied by post-tsunami reconstruction aid promoting new livelihoods. She is divorced and recently remarried to an ex-combatant who, at the time of our first encounter in 2012, was serving the last stint of a four-year sentence in prison for possession of marijuana. Home for her, then, consisted of a number of houses located in completely different parts of the city that I was invited to visit: we lunched with her ex-husband, for example, who had vacated the now empty and unused tsunami-aid house after their divorce and lived in a smaller wooden hut just behind it. We also visited the prison, where her tasks included bringing her new husband medicine for his conflict-injured and infected leg, collecting his dirty clothes for washing, and carrying letters to the ex-GAM governor pleading for medication for the leg injury that neither the prison nor he and his family could afford. During my encounters with the residents of Banda Aceh, I realised that, alongside the more formal state and municipal governance-led social welfare schemes, these letters, and a favourable response to them by those in power, were an important way of attaining social security in the aftermath of the tsunami and the conflict. Yet, these letters also told a story of reliance on patrimonial patron-client relationships and underlined the hierarchical nature of the political economy after the tsunami - letters that were performative in terms of power and its hierarchies, and a collective tie to the leader (Nordholt and van Klinken 2007, 4).

Mariyani: We [Mariyani and first husband] were married no less than 18 years before we separated ... because of another woman. From then until today she has formally been the new wife; he married her after he had divorced me. But he had been seeing her for a much longer time. That is my destiny; from earning my first penny, until earning slightly more, I have suffered a lot.

Marjaana: How did it feel when you heard about it for the first time?

Mariyani: My heart broke and I was sad. Very, very sad. I wanted to die more than anything. That's how I felt.

Marjaana: Did you tell him that?

Mariyani: No, we [I] have never confided that to him, there are not many people with whom one can share that feeling.

Marjaana: And then finally you got divorced. For how long did you consider it?

Mariyani: I was not thinking about anything like that. It was he who wanted to divorce me.

Marjaana: Oh, it was he who started the process?

Mariyani: Yes ... if it had been up to me, I wouldn't have. I have never said, 'I will leave you because of what you are doing', never.

Marjaana: But you also did not feel comfortable because he had another woman. 
Mariyani: When it started happening, he went directly to the court to divorce me. After the divorce, I was divorced for one year, then I got to know my second husband.

Marjaana: And where did you meet your second husband for the first time? Mariyani: At the court.

Marjaana: In the canteen, or where?

Mariyani: Oh, it was in the court of a prison, because he was not allowed outside during the trial.

Marjaana: Oh, it was when he was on trial?

Mariyani: Yes.

Mariyani tells her story in the third person while referring to herself:

Mariyani: It's like this ... it happened because of the divorce case with her husband, so Mariyani is stressed and Mariyani's mind is chaotic ... She got to meet him, got to know him. It did not mean Mariyani was in love with him, no. It was because Mariyani was sad to see his condition, health problems, the shot wound from the conflict. He was using walking sticks, so I was quick to feel sorry, feel empathetic towards him.

Marjaana: Do you still have contact and good relations with the first husband?

Mariyani: Yes, because we have children.

Marjaana: Oh, because of the children. That is good, because sometimes relations with ex-husbands are not that good.

Mariyani: I have good relations with everyone, not just with my own family, but all people; I don't differentiate based on religion. What is important is that we live so that we have good relations with everybody.

In a difficult position, Mariyani came home crying, felt sorry for him ... How was his position? Who saw him? Nobody saw him except Mariyani. He once asked for water ... 'Sis, bring one Aqua, sis, I am very thirsty.' But it wasn't just Aqua that Mariyani bought that time: cigarettes, snacks and drinks Mariyani bought. He said, 'Thank you very much', to Mariyani, 'this is kindness I cannot repay, but God will.' So, Mariyani felt sorry for him because he was such a good man at the time, right?

When I brought food for him, he thanked me; he said he cannot repay, but that God will. He then said that he wanted to marry me (bersaudara). Day after day, month after month, I went back, 'Sister, sister come back to the prison.' When I went there, he said, 'Sister, I don't have anyone here to talk to', so I went back there often. Once a week I went there. He would always tell me about him, he would say that he was sad when I was not there, that his family is far away, that no one except I visits him. 
So then, as a woman, I started feeling familial love towards him, when he says that I treat him like a younger brother.

The first days he said that he cannot respond to what I have done to help him, 'I like you', he said. I responded, saying, 'No way, I am older than you, I have three children, it is not possible that you become close to me like a younger brother.'

'I truly like you', he said to me. So I started thinking, maybe it is for real.

After getting married and waiting four long years for the sentence to be over, it seemed that, although the constant visits to the prison caused her stress, Mariyani was feeling quite content, perhaps because she was in charge of her own life and surviving economically on just her own earnings, and perhaps because there would be a new family life after his release. Her income seemed sufficient on a good day and when healthy and able to pedal. The park also seemed to offer a female space consisting of networks of women ready to reflect on the gendered expectations of their lives, joke about men and create room for leisure in the midst of hard physical labour.

Yet, as the release of her husband approached, her worries grew. How would they integrate their lives together? How would she and her children's lives change? Stories about new husbands and their ways of treating stepchildren told at the park were not encouraging. An especially traumatic experience, repeatedly narrated by these women, was the case of the rape and murder of a 6-year-old girl, Mardiana, by two men who had brought her to play in the same public park, one of whom was her under-age uncle. In the weeks before her husband's release, coinciding with the forthcoming parliamentary elections, some of his ex-combatant friends started visiting the park frequently and inquiring for information about him. Wearing massive rings and expensive watches, they carried mobile phones and were accompanied by young women whom they introduced as 'nieces'. Her husband and his comrades had moved to Banda Aceh from East Aceh after the MoU was signed.

The arrival of the husband changed the household dynamics, but also those at the park. The children began complaining; the husband grumbled about the children taking his motorbike; and Mariyani looked increasingly tired when arriving at the park with the merry-go-around, complaining, 'My life was so much better without him.' His being unable to take on the male role as head of household in charge of family finances was difficult for both of them. Despite his injured leg, he visited the park in the evenings carrying brochures about water purifiers and dispensers, and herbal products meant for home sales, meanwhile boasting about ambitious business plans based on promises made by other ex-combatants to involve him in projects back in his own district. All of these would materialise once he was reunited with his commander, although that moment seemed to remain permanently in the future - as did the promise of a cure for his injured leg, which, rumour had it, had been made by the 
current governor himself. In November 2014, the leg was finally operated on in East Aceh, but the infection had swollen the leg badly.

Mariyani: He was not happy about my children. I was really sad. Then he returned again just as I heard a rumour that he has got married again. I felt so crushed, Marjaana. But my children do not know about it. My husband's friends tell him, 'You've been married to Mariyani for many years already, for five years. Are there children?' 'Not yet.' 'Just look for another one; just marry another one'. He has many friends like that, friends who have remarried.

\section{At the legal office}

Mariyani: I had divorced my first husband, and this is the second. He is younger than I am. We got married when he was still in prison. I knew him for a year and then married him. When he got out of the prison he often returned to $\mathrm{X}$, because he is from $\mathrm{Y}$; his name is $\mathrm{Z}$.

Lawyer: 'Returns often, why does he do that?'

'Work is there', he said. Husbands can do that, right?

So, 2015 - I got married to him in 2011. He returned there for about 3 months, I heard that he had remarried but I was not sure because I had not seen it myself. So I called him. 'Husband, I hear that you have remarried, right?'

'Who said so, don't believe what people say'

'Well if they say so.'

'No, that's rubbish. Lillahi Ta'ala [for Allah] - there is no other woman than you', he said. 'I have not married', he said.

I went to do henna at event $\mathrm{W}$ and a woman came to pick me up. When I reached there, people told me that my husband had married her.

Lawyer: Who said that?

Mariyani: The villagers, neighbours. So I called him. 'Please be honest if you have married, please be honest with me. I am your wife, right?'

'Who speaks like that? I want to meet that person', he said. 'If you don't believe me, let's go to Abu wahab Ulama, let's X (bersumbah) later', he said.

Let God show me the better way. So, at event W I asked from a friend, 'Hey, is it really true that he has remarried?'

'Yes, he has.'

'Where does she live?' 
'Y'.

So that day I went to her house, but I did not enter her house. I asked the neighbours: 'Assalamu'alaikum ... walaikum salam ... is this the house of X?' 'Yes', they said, 'why? Are you the cousin of her fat man? That fat man?'

'Yes', I said. It means that what I was told was true.

Lawyer: If it is nikah siri [unregistered marriage] in religion, it is often said that Islam allows it, but polygamy is not necessarily like that. Not as secretive. If you give your permission, what is the reason for polygamy? If there are no children or there are other reasons that are compatible with the Islamic law, [that is one thing], but if there are no other reasons, it means it is illegal. It is your right to report it to police, but it is now up to you what you want to do. If you still want to continue in a situation like this, it means that you will continue with your husband. It means that he will be going to $\mathrm{X}$ - has he really left her, the informal wife? If not, it means that it will be up to you if you wish to say goodbye. I will not make decisions for you; it is not our office's (P2TP2) role to suggest a divorce, it is your decision. What is it that you want now?

Mariyani: I do not want polygamy. That's all.

\subsection{Cursed by the Second Wife}

After having spent some time at Taman Sari park in 2012 (see Chapter 2), where I often had random discussions with those working there and also with people who became curious to know who I was, I met Indah, originally from North Aceh. I ended up sitting with her in the park for five hours, discussing her strategies and attempts to be healed of a curse that she believed had plagued her for a long time. In my notes, I remark that sometimes it is difficult to know what is 'real' and what is a story concocted as the result of imagination or exaggeration, or purely for entertainment. I add that I had, for the purposes of my research, given up on the idea of searching for authenticity, or 'the truth', but rather considered these random encounters in the park as processes of creating aesthetic subjectivities in the urban space, and in the eyes of a foreign researcher (see also Chapter 1 ).

Like many others, Indah had moved out of Aceh during the conflict years, first to Jakarta and then to Kuala Lumpur, where she married and had two children. Her health problems started when her husband married another wife, with the relationship between the two women resulting in quarrels and fights. Indah said that the second wife had used black magic (dukan-dukan) on her, after which she was thrown out and became ill. The husband kept the daughter, and she returned to Aceh with her son, who was being taken care of by a sister whose family members live in Sumatra and Australia. She had no immediate family members left in Aceh and she felt lonely. The main reason for coming 
to Banda Aceh had been to get rid of the curse, but so far she had had no luck. In fact, she had been to many traditional healers, but some had just tried to rip her off. The healer she was regularly visiting in Banda Aceh at the time of our discussions, however, had convinced her, and she was determined to be cured by him. Later, I learned that she had lived in Banda Aceh much longer than she initially shared with me, and that she is one of the women who 'works in the street'.

Being away from her daughter had both a physical and an emotional effect on her. Pointing at her head, she said that the distance and being apart is corporeal, it affects her body and being. The distance accumulates as embodied feelings. While we are talking, we are joined by Mar, and it feels like two friends meeting each other. These two women share an emotional sphere in the city: the discussion moves from one story to another and on to expressions of anger towards men who decide to remarry without taking financial responsibility for their previous wives. Getting involved in new relationships is risky, as there is no way a woman can $100 \%$ trust a man; regardless of what they say, they may have women 'here and there'.

The public emphasis on Islamic dress and women's respectability, particularly in the urban sphere, has had an impact on how I write about Indah in my notebooks. I describe her loosely worn woven scarfs, her hair managed as a bun, the red chiffon blouse, black jeans and sandaled feet - but what to make of it? I even end up writing in my notebook that this is the closest I may have come to a prostitute in Banda Aceh. Yet, when writing this chapter, I also read the following quote in my field notes:

[A]nalysing historical inconsistencies or incorrectness, they may reveal ... deeper emotional significances, both personal and collective, and Portinelli insists on acknowledging the importance of imagination, or what he terms 'the subjective projection of imaginable experience.' Representativeness, he argues, rests not so much in 'what materially happens to people' as in 'what people imagine or know might happen'.

Waterson 2007, 15

Regardless of what 'reality' is in Indah's case - in the context of marriage, becoming the second wife, and managing its aftermath - she is attempting to seek a cure to the black magic set on her by the second wife, and trusting that the traditional healer will be able to chase the evil spirit from her body/chest. $\mathrm{He}$ is a man in his 60 s or 70 s who incarnates in the healing process as an old, Malayu-speaking Batak lady, through whom his/her patients are treated. The healer's home is full of people waiting their turn for a session lasting just a few moments, all of whom can hear the healing session and also form a social network for the one being healed. Through the old lady, the healer asks questions, but also learns facts about the patient that he cannot know otherwise. At times, he protects his patients when angry husbands arrive claiming their wives 
are involved in black magic, but he also defends boyfriends who, it is claimed, have taken part in the entrance of evil spirits into a girlfriend's body. There is, he says, a clear distinction between the work of a bad spirit and an illness that requires hospital treatment. As Indah retells it, the treatment hurts, as it makes the evil spirit move within her body, not wanting to leave. Furthermore, several treatments are required as the spirit cannot be chased away in one session. Indah is convinced that the healer can help her, and she also believes that the popularity of such treatments is an indication that men's sexual drives and polygamous behaviour can make women ill. Later, Indah migrates back to the central Acehnese region, and her friends in Banda Aceh lose touch with her.

\subsection{Grandmother Really Understood $\mathrm{Me}^{5}$}

A good mother focuses on three generations of women and mothers in a family who belong to the Banda Acehnese ethnic minority Chinese community. The pain that loyalty may cause, forgiveness and survival are explored through the story of the granddaughter, daughter and a mother.

My mother, maybe she doesn't have that kind of parent's love to children, because [to her] it is all about money.

In this story, home is constructed in multiple locations in Banda Aceh and Medan, shifting due to multiple dramatic events in the past. The story belongs

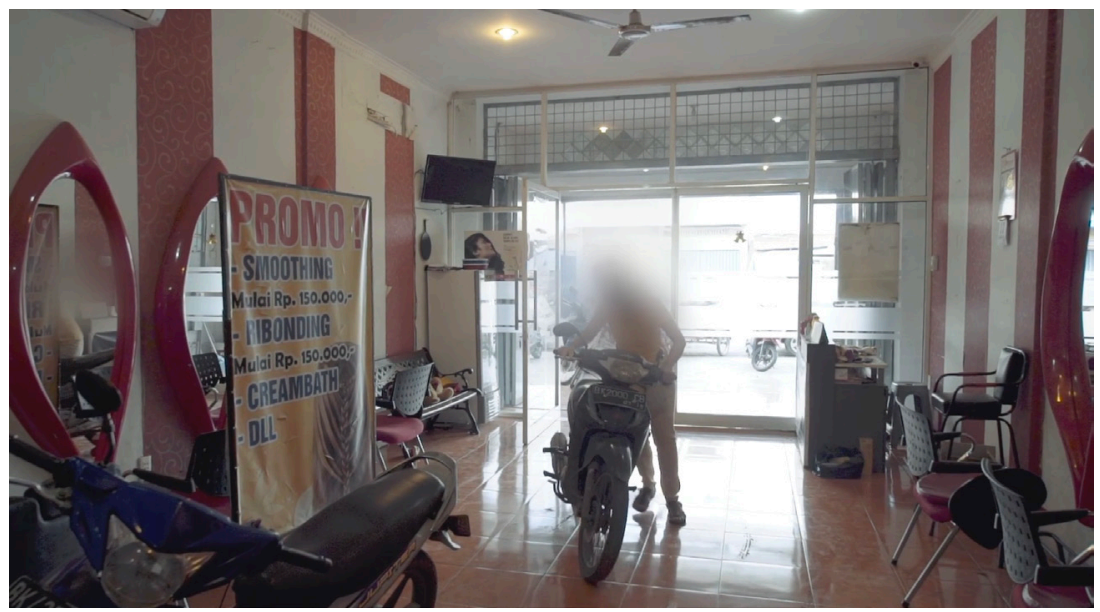

Video 8: A good mother (07:37).

Source: Scraps of Hope.

To watch this video, scan the QR code with your mobile device or visit DOI: https://doi.org/10.33134/pro-et-contra-1-video-8 
to ChaCha, a woman in her 30s who was born in Medan and abandoned at the Buddhist temple, to be later adopted by a Banda Acehnese woman. Having lived most of her life in the Chinatown of Banda Aceh, she now lives in Medan. We had met six months earlier in Banda Aceh, only a few months after an Islamist group had attacked the Sunday mass of a Christian Pentecostal congregation of which she was a member. Despite several applications, the congregation had not been granted a formal licence for worship by the municipal government, and Sunday mass and the children's Bible school was arranged in a converted commercial space behind metal security doors. She had no hatred for the attackers, she told me, yet, from the intensity of her description of the events, it became clear that they had left marks on her understanding of basic safety in a neighbourhood where she had lived all her life.

Now, six months later, having followed her husband to Medan, leaving two of her sons in the care of her adoptive mother in Banda Aceh, growing distrust of her mother is turning into agonised feelings of loss. 'I was never close to her', she says. 'I was brought up by my grandmother who died in the tsunami'. Suspecting that she has disappointed her mother, who wished her adopted daughter to become as successful as she had once been in the beauty salon business, she feels that her mother appreciates very little, if anything, about her. On the contrary, the memory of her deceased grandmother - 'taken away by the tsunami' - seems to play a crucial role in any feelings she has of emotional belongingness and worth: 'She was the only one that paid attention to my details, my marriage, my needs, my feelings.' Telling me about a violent ex-husband, she says that only her grandmother had cared enough to say to her directly, 'Don't lie to me, I saw your bruises, don't lie to me. I never planned to give you to a man who would do something like this.' She continues, 'My grandmother's neighbourhood was washed away in the tsunami. When I lived in Banda Aceh I regularly went to the ruins of her house to cry and commemorate her ... But now I try to move on, accept my past, move on day by day, and I just let it flow, let it flow.

ChaCha's story involves inter-generational relations and conflicts, but also questions about social and biological motherhood. Her mother established the first beauty salon in Banda Aceh in the 1970s and became famous, with regular customers from the upper-middle classes and economic elite, such as the wives of governors and army and police officers.

So my mother had a huge place and, you know, lots of employees and I came like a princess, suddenly parents were delighted, like a princess coming [gets excited] ... So I was raised by a lot of my mother's employees. So, actually, my childhood is quite OK.

We chat about a picture ChaCha has sent me of an early birthday party in which she is wearing a crown and holding a plate of cake and sweets.

I was 5 or 6 years old. Many people were invited to birthday parties at that time. It was organized at my mum's salon. All the students from 
kindergarten were invited. Known and unknown ... [laughter]. My mom arranged the party. And of course my teacher was also invited. I don't remember the details. But I remember I got so many presents and I was so happy. My grandma was there too. That even made me more happy. That was a big party [laughter].

Being brought up as the daughter of a successful beauty salon owner was not easy. The expectation of oldest daughters has been that they should follow the path shown by their mothers. Negotiating the meaning of success is a constant struggle: trying to make the case that economic wealth or well-being is not the only way to measure life's successes, that there are other values that are relevant too. ChaCha's relationship with her mother has also included silences.

My parents never told me anything about myself, I mean, when they brought me home, and where they found me, never. But I was told by many, many, by different, different employees of my mother [at her salon] that I was found in Medan, actually in a Buddhist temple. I have asked many questions about it myself and, yeah, my biological parents left me in a Buddhist temple, it is like that. And the temple priest asked my mother if she wanted me or not. And then she decided to adopt me. When I was 16 or 17 I decided I didn't want to know about it anymore. This is who I am. What made me today are my current parents, that's it.

In times of hardship, as discussed briefly, support had always been available from her grandmother:

She's the only one that paid attention to my details ... [She] wanted to know more [emphasising] about my marriage ... just really wanted to care about my marriage, really cared about what I want, what I need, really cared about my feelings, which my mother seldom asks about [laughter]. Yeah, but she was taken away by tsunami [silence].

My grandmother ... She was crying, my grandmother, when she asked me about my marriage, and she said to me, 'Don't lie to me. I saw the bruises, don't lie to me.' Which my mother never says at all. Maybe my grandmother and mother are just totally different persons. My grandmother is more interpersonal ... but my mother is [not] that kind of person, but inside maybe she is concerned. My grandmother, she is right when she said to me, 'Don't lie to me. I never planned to give you to a man who will do something like this.' I [felt like I had been] stoned and I cried. I quietly cried. And yeah, that's why I decided, that's it, when I said that is enough.

Sometimes life matures you. When life is getting hard on you, you're getting mature. You just have to receive it, accept it, and then move on! If 
you say that I don't complain, I have so many complaints about my life, but I decided not. I have so many things to be grateful for that I move on. I now have a loving, lovely family, lovely son, loving husband which is more than others have.

I am still trying, still have a lot of struggle in my life, still today ... you know, you have three sons and you care about their education, not that they have to go to the best school but to have so limited income, [I] struggle like that. Still, I try to accept it, move on day by day and ... just let it flow, let it flow.

I think I am a simple person. Well, I am a simple person ... I decided, OK I want, I will get married, and I want a simple life. OK, if he wants me to be just a housewife, OK! No problem, I have no problem with that. But ... domestic violence, it is a different story [silence]. So, when I experience some hard times there, I decided to run away, run away from Java, without him knowing. So I flew back to Banda Aceh. By that time, I already gave birth to my first son. He was living in Banda Aceh, because after I gave birth I titip - how do you say titip? - menitip him to my parents, because with my ex, nobody is looking after my son when I want to look for a job. So my parents said, 'OK, no problem. Please give us our grandson, [we] will take care of him.' So, when I gave him to my parents and I flew back to Java I experienced some hard times, and I flew back then to Banda Aceh, and then I stayed when it was tsunami, 2004 December. Then my ex-husband called, 'I am sorry, OK? I was worried about you [in the] tsunami. Just give me another chance.' I said, 'OK.' I never wanted to get a divorce, because I have kids [to support], right? Then I told my mother about me wanting to go back to my ex-husband, she said, 'OK, I will take care of everything.' After I took my son with me, I got pregnant my second time. It turned out that he never changed, so I decided to fly back again, [and] I settled in Banda Aceh.

\subsection{What to Do If No Children Are Mine?}

Married to a paramilitary police officer (promob), one day Putri takes pride in explaining how she can assemble and dismantle a machine gun. When I ask why, she tells me that, as the wife of a police officer, she is automatically part of a wives' association that is not only about being married to a policeman, but that this also socially connects her to 'wifeness' as it is constructed at the national level, as State Ibuism (see Chapter 2). Wives' associations have a specific performative role when it comes to the annual celebration of the Indonesian police force, one aspect of which consists of a competition in assembling, dismantling and cleaning a gun. The couple has been married for five years, but, so far, they have no biological children. At first when we meet, Putri does not raise this as 
a concern for her future or her marriage, but along the way, when we have had more time to talk, also discussing my own status as a middle-aged researcher with no children, our encounters open up a space to explore the challenges and possibilities entailed in being a childless but married woman.

Due to her husband's work as a paramilitary police officer, he travels a lot. Putri has agreed with him and her in-laws that on such occasions she can help her natal family with home-based income generation, that is, by keeping a small kiosk at the back of their house and also selling home-made soft drinks and snacks, such as fried baksos, to the neighbours. Most of the time, therefore, we meet each other at her mother's house, although once we visit her in-laws, where she and her husband formally live in a small house that is on the same plot of land as the homes of other extended family members. On a wall in their bedroom are photos of a baby, arranged in a cute collage. Those are of Abi, her nephew, whom I at first mistakenly considered her biological son, as during the first months when we meet and talk she has the main responsibility for taking care of him. Later, I learn that Abi's parents are employed and live in another town, and due to their workloads, Abi stays with his grandmother. The photos of Abi are from a period when he had become seriously ill, and it was not certain if he would pull through.

As the oldest daughter staying in her maternal home, Putri partly carries the worries and concerns of her mother, who has been the head of house in the years since her husband died. After the death, the family income dramatically collapsed, and now all those family members who are able to, contribute to the household economy. Normally, this would primarily be the responsibility of the only son, but he has not, to the great disappointment of the rest of the family, shown any signs so far of shouldering the burden - quite the opposite, as he has joined the street punk community in the city (see Chapter 5).

'You should join us! We will invite all our neighbours on the anniversary of the death of my husband ... It is to make sure that the violence of that man is not continued by my son', Putri's mother said to me one day. The next day, Putri picked me up on their motorbike to join her and the rest of the family for the annual commemoration of their father's death. They have conducted this ceremony with the other women from the neighbourhood, ever since he died, to break the chain of (gender-based) violence in the family. Among Gayo (an ethnic group in Aceh to which Putri belongs), this ritual (bimeren) is used to heal violent or emotional behaviour. According to the family, the violent traits of a father are transmitted to his son after his death and move on to the next generation in turn. As part of the ritual, the mother of the house kills a black hen and it is prepared as a special meal that consists of the chicken, rice, and water, served on a big platter. The expectation is that the son of the family will eat from the plate first, followed by his sisters. Sometimes, when the son is absent from home because of travel or imprisonment, the ritual remains incomplete and such occasions are referenced when unexpected or negative events occur. Older siblings retell the stories of the violence in the family; it made them so 
scared they ran from their homes. It was not just the actual physical violence, but also the unpredictability of the moods and the behaviour. Perhaps the quarrels and disagreements caused by the older sister, and the influence that it may have on their young son, Abi, impact on Putri, pushing her to take the mothering role that is so strongly advocated through the police wives' association and their focus on dharma wanita (duties of women).

Staying in the government-owned housing community after the father/ husband died caused economic stress. The authorities informed them of a rental increase which, with the husband's monthly salary, would not have caused such concern. Without any sustained monthly income, however, and with their mother's deteriorating condition due to severe diabetes and insufficient funds to buy insulin regularly, the economic challenges remain a constant struggle - despite the fact that the provincial government has implemented and advertised health insurance that guarantees all residents of Aceh free medical care and basic health treatment. Yet, the reality of the scheme from the perspective of this family is that hospitals do not necessarily provide treatment for free and, as for the insulin, the doctor's recommendation for their mother is not included among those medications which are covered by the insurance scheme. Thus, Putri's mother continues her daily life without injections.

The situations of Putri and one of her sisters are slightly better as they have both married government officers, one with the police and the other in the army. Putri's rights as a wife, in her description, include a monthly share of her husband's salary, which she routinely uses to help her mother or her siblings. Not yet having children of her own allows her freedom as a married woman, she tells me. This would change if a child were born, as it would recompose her position as a wife, she adds. Currently, however, her days, although also consisting of sharing responsibilities with her mother, are spent with her younger sisters who are still in their teens, both studying and making plans for their future.

The alley, or the home street, forms a semi-private sphere where the rules of Islamic dress and separation of the sexes are not followed as strictly as just a block away on a major city road. Here, the sisters meet with their neighbours, teaching the younger children to play, but also flirting with labourers on a construction site, who clearly enjoy witnessing the playfulness and laughter in the street. 'As long as it does not become real', comments one of the neighbours who passes by. Visits to the beach, although they also recall bad memories of the tsunami morning, offer a release from daily stresses that include concern for the well-being and future of their reckless brother, but also more generally, their economic situation. The sisters also embark on more adventurous travels to the 'Arab nation', an area known for its temporary marriages, or 'contract marriage' (kawin kontrak in Indonesian, nikah mu'tah in Arabic; for detailed analysis, see, e.g., Arivia and Gina 2015) and the escort system created for Arab tourists in Bogor, West Java. The version of the trip I am told focuses on the beautiful clothes the sisters wore, the travel outside of Aceh and Sumatra, and the hotels in which they stayed in Bogor. 
One day, when we meet after a long break, Putri tells me that she has moved back home and has divorced her husband. It did not work out without children, she says.

\subsection{Smile as a Self-Care?}

This chapter has focused on a selected number of Banda Acehnese women's life stories, and their narratives of the management of their life challenges, dreams and wishes during the ethnographic, life-historical, video-production research encounters of 2012-2016. Thus, it differs from Chapter 2, which focused on the narratives of the 'new woman', comprising explicit attempts to construct gendered Islamic piety through the upper-middle-class ideals, female leadership and gender machinery of the municipality. Chapter 2 also drew attention to urban spatiality as a contested sphere, where city visions, such as kota madani, are laid out for its citizenry through political economy, culture, consumption and situatedness in the city. Where do these women's stories fit in that frame? How separate are these two spheres of the urban from each another?

Rather than seeing them as opposites, or as not connecting to one another, I suggest that the above narrations of struggle, manoeuvring, management, selfcare or simply performing the role of dutiful wife as part of the police wives' association are ways in which the biopolitics of peace becomes embodied in the urban. Such narratives witness continuities and new patterns of conflict, violence and displacement, but they also illustrate that no Acehnese woman's story can simply replicate that of either a resilient new docile woman or an oppressed Muslim woman. Furthermore, as suggested in the Introduction, younger unpublished scholars and activists in Aceh have, in any case, remained cautious about the possibility that the notion of docile and resilient agency can provide sufficient theoretical framing to analyse the gendered politics of Aceh.

In a similar fashion, Mahmood's (2012 [2005]) analysis of everyday piety is critiqued for lacking diversity. In Aceh, the politicisation of the private sphere and the adoption of post-conflict legal frameworks have produced jurisdiction that renders certain gendered bodies and their desires illegitimate and immoral, meanwhile legitimating state violence targeting both Muslims and non-Muslim minorities. Yet, at the same time, it is apparent that transnational Islamist revivalism, the da'wa movement, and the focus on gendered piety are providing new openings for the care of the self and agency for others. Thus, these are the stories through which the city breathes and comes alive: through, for example, Indah's careful explanation of the contested nature of her plot of land and the embodied experiences of that contestation, but also the revelation granted by the knowledge of plants and the beauty visible from the door of her house. Thus, rather than reading the smile as hiding a sorrow, one may ask: in what ways could we read the narratives as practices of self-care, and thus, also see the smile as an attempt to make life liveable? 
CHAPTER 4

\title{
Subjugated Post-Conflict Masculinities
}

\author{
From Premanisme to Sufism
}

\subsection{The Many Faces of Masculinities}

The last two chapters have approached the politics of gendered reconstruction of the city of Banda Aceh by focusing on the ideal kota madani and the contestations of pious womanhood (see Chapter 2), and by drawing on life-historical reflections of women in managing their womanhood and respectability (see Chapter 3). Following such stories, this chapter focuses on urban masculinities and the ways in which they are performed and negotiated as part of the ongoing peace process: examining violence, care and healing in the midst of postcolonial continuities of economic grievance and quests for social justice.

The narrative follows lives of two ex-combatants, one in his $60 \mathrm{~s},{ }^{1}$ the other in his early 30 s, and the ways in which they negotiate their belongingness to the ongoing peace process, and its political, economic and violent consequences. It revisits contemporary urban encounters with violence and the preman gangs ${ }^{2}$ the Sufi healer has left behind him, from which the younger man draws his sense of belonging and scraps of livelihood. The chapter ends by reflecting on a decolonising theory, or subjugated knowledge (Foucault 2003), knowledge that is excluded from dominant discourse, of vernacular forms of reconciliation, care and healing - which the Sufi healer calls 'foolish knowledge' (Imu Bodoh) - that are connected to the oral transmission of Malay traditional healing practice; they also have links to the 40-year-long war against the Dutch, known as the 'Dutch War' (Perang Beulanda), the 'Infidel War' (Perang Kaphé) and the 'Holy War' (Perang Sabil) (Alfian 2006).

Yet, this chapter embarks on this journey by visiting the construction site of the Wali Nanggroe palace (literal translation: 'guardian of the state'), the customary leader and symbolic head of state position, formalised as part of the Helsinki peace settlement in 2005. ${ }^{3}$ At the time of this research in Banda Aceh, the Wali Nanggroe palace was nearing its completion, and its high costs 
and low quality of construction were heatedly debated in local media. As my daily visits to the Sufi healer usually included reading and commenting on the daily newspapers, issues concerning the post-conflict political economy and adequate and sufficient housing became prominent. The Sufi healer would say in our recoded sessions, for instance: 'Buildings have no significance for ordinary people. High-rise buildings are no use for people, if their stomachs remain empty' (Scraps of Hope recording, 6 December 2015/0005.mp4).

The economic reality for most lower-rank ex-combatants like himself remained economically challenging. In fact, as Abdulah (2018) has illustrated, the peace process stipulated in the MoU allowed, perhaps unintentionally, gendered remilitarisation of Aceh, through the DRR process that echoed the hierarchical structure of GAM, but also that followed a militarised, hegemonic masculinity ideal of 'Acehnese man', in which ideal constructs and divisions were made between the ideal 'warrior hero', father figures (i.e. military ex-commanders) and others were made. Furthermore, during the delivery of ex-combatant rehabilitation funds, these gendered notions of hegemonic masculinity were further used to differentiate ex-GAM soldiers into three hierarchical categories: those of 'true GAM ex-combatants', who fought in the jungle and battlefield until the MoU was signed in August 2005; and 'escapees', who were GAM soldiers, but who had either fled, were detained during the Indonesian counterinsurgency campaign between 2003 and 2004, and were still considered as GAM soldiers if they expressed their loyalty to their former supreme commander Muzakir Manaf, who became vice-governor of Aceh for the period of 2012-2017. Finally, there were 'the excluded', those who had surrendered themselves or joined the Indonesian army affiliated group FORKAB (Forum Komunikasi Anak Bangsa) (Abdulah 2018, 87-93). Accordingly, Abdulah suggests that the peace process created a new peacetime political economy and ideological construction of masculinity from which the GAM military leadership benefited and used to gain access to political institutions and economic resources ${ }^{4}$ (ibid., 70). Abdulah further suggests that those who were left outside, mainly the 'escapees', still considered as former GAM soldiers, had the hardest time economically and politically. They were sidelined and were "knocking on government office doors to ask for money, or they have returned to their old practice of applying an informal and illegal tax or security fee to business people who undertake local government infrastructure projects' (ibid., 83). The ones who were reinstated to their positions on the higher rungs of the ladders were able to reinstate their bapak (fatherly, patriarchal) roles (see also Chapter 5) they had during the conflict period, and successfully create a 'peace industry' to gain economic and political elite status, and who considered themselves to be safeguarding the MoU (ibid., 114-116).

As this chapter will illustrate, for the Suf healer, the political and economic contradictions of the peace produced an ideological conflict between what the war effort had signified for him and the reality of everyday lives in peacetime had turned out to be. But instead of settling for protest masculinity, turning 
to Sufism and traditional healing, he offers non-violent decolonial trajectory for Acehnese military masculinity. When the life-historical videos were screened in conflict-affected rural villages in one of the districts, female excombatants and conflict-affected women in the audience reacted to his analysis strongly and reiterate Abdulah's (2018) analysis of their post-conflict situation within the gendered ideology of militarised hegemonic masculinity:

The story of the man with the coffee shop is like ours, but in fact it is much worse in the rural areas.

We have tried everything already, but our situation has not improved. We want to farm land, but money available just isn't enough for it.

It is not a question of luck. Pests destroyed the rice harvest. Returns of the labour is not as simple as one assumes.

We survive by taking loans from the 'loan sharks'. You get $6 €$, and you pay back $10 €$.

I am one of the ex-female combatants. But no one in the government has formally recognized my status. All shines around me: faces, eyes, lips, shoes. It's all sleet. I go to rice field every day. No one is interested in us anymore.

When I was tortured during the conflict I was 7 months pregnant, my child is a girl now. I cannot afford to let her go to school. With the limitations that exist today, there is nothing I can do. Post-peace business capital we do not know about. Not up to now, but at least not for my child. For me it is not necessary because the child is born with all the flaws.

The Wali Nanggroe palace, located in a grandiose isolation in the southern part of the city in the middle of former rice fields, was completed in 2016 after the provincial government had spent over 100 billion Rp. (c. US\$7.5 million) on its construction. The palace architecture resembles the European pillar structures and aesthetics of the French garden style of Louis XIV and locally it led to a number of conspiracy theories claiming that it marks the spread of Judaism and Freemasonry in Aceh (Assyadath 2015). Houses commissioned more generally by the new, post-conflict elites in Aceh tend to exhibit their new wealth and power with their grandiose architectural styles and size, such as that of a regional-commander-turned-politician on the west coast of Aceh, whose residence and adjoining garden also replicate the Louis XIV style, with a deer brought from Russia.

These public displays of wealth are a form of performed masculinity that provides an interesting contrast with that of Acehnese Sufist asceticism, which is 
arguably in a constant process of negotiation, rather than static, unchanging and singular, as earlier references to Acehnese masculinities may suggest (see, e.g., Aspinall 2009a,b; Rasyidah et al. 2016). However, such displays of wealth and power also constructed as reflections of Acehnese nationalism and pride are traceable back to the colonial period, as the extract from the only remaining letter sent by the Sultanate of Aceh, Iskandar Muda (r. 1607-1636), ${ }^{5}$ sent to King James I of England in 1615 illustrates:

A letter from His Excellency Sultan Perkasa Alam, the Sovereign Champion, the king who possesses kingly rank, who is upon the throne of a kingdom which (human) vision cannot cover nor (human) hearing fully comprehend, whose palace is of ivory, engraved with network, with joints of red-lead, of the colour of vermilion and gilt, whose palace front extends as far as the eye can reach, whose river is enclosed with marble rocks, like unto a polished mirror, who has water pipes of gold set with jewels and many water pipes of silver. The king who holds in his possession treasuries of gold dust and silver dust, and of gold mines in the country of Priaman in the Salida Mountain; who holds in his possession nine kinds of jewels, who has umbrellas of gold, one carried on each side of him, weighing hundreds of catties, whose throne is of gold, whose cushions are of gold. The king who holds in his possession a horse with a golden saddle, with golden trappings weighing hundreds of catties with a golden bit set with jewels ...

Gallop 2011, 244-245

The letter follows Malay court letter structures: the first part consists of compliments addressed to the receiver, but significantly also of those describing the sender - as apparent from this extract. It describes in detail Iskandar Muda's sovereign status, his possessions and the territories under his rule, outlining his master plan for conquering the whole of the Malay peninsula. In a nutshell, in the letter, the Sultan refuses the British permission to trade on the western coast of Sumatra and, rather, invites them to trade in Aceh (Gallop 2011, 109110). Compared with the peaceful diplomatic skills of his successor, Sultanah Safiatudding Syah (r. 1641-1675), which focused on loyalty, respect and cooperation, Iskandar Muda's masculinistic reign, celebrated widely as the 'golden age' in Acehnese history (see also Chapter 2), seems to have showcased other faculties, such as jealousy, rivalry and competition (Khan 2007, 2010, 2017).

Yet, how should one study and account for post-conflict masculinities and their (post-)colonial legacies? There is a danger of essentialising and exoticising Acehnese masculinity into an ahistorical and unchanging form of hegemonic masculinity ignoring forms of non-violent negotiation, homosocial bonds and relations as spheres of caring practices (Duriesmith 2015; Cornwall 2017; Kunz et al. 2018; Vaittinen et al. 2019). Some of these may have an increased appeal, however, given an increased global focus on racialised masculinities and 'security risks' that potentially brown (Muslim) men entail for successful 
reconstruction of societies (Enria 2017, 241), or uses of simplified gender analysis to combat violent extremism, seem to offer (Ezekilov 2017). Association between masculinities and violence and conflict, using the concept of gender, is increasingly common; at the heart of such a notion is the reduction of gender roles and norms into a dichotomy of women as victims and men as perpetrators (Zarkov 2001, 2008; MacKenzie 2012; Myrttinen et al. 2016; Enria 2017). Constructs of Middle Eastern (Muslim) men, in particular, draw on the elements of patriarchy, dominance and violence (Inhorn 2012, 15), also common in gender policies of post-disaster and post-conflict reconstruction in which men are portrayed as 'policy problems'. Moreover, poor, uneducated men are depicted as oppressive, lazy and violent, and therefore in need of reform (Bedford 2007, 2009; Jauhola 2013). In fact, it is suggested that theorising on post-conflict masculinities has lacked in-depth understanding of variations, contextual specificities (Myrttinen et al. 2016; Cornwall 2017, 35) and historicity, all of which challenge the analytical reliance on 'monolithic ethnographic presence' (Cornwall 2017, 35).

Until recent years (Duriesmith 2015; Kunz et al. 2018), research on the armed conflict in Aceh only theorises masculinities explicitly in passing. However, close reading of Edward Aspinall's research on Aceh's independence movement (GAM) (Aspinall 2009a, 2009b) provides an interesting insight into how the GAM as a movement was, from the 1970s onwards, constructing hegemonic masculinities ${ }^{6}$ in Aceh (this is expanded on by Abdulah 2018; see also Jauhola 2013, 100-104, 120-122, 125-130). Key to these constructs are kinship relations, strong village-based male bonds among fathers, sons and brothers, strict sex segregation due to both matrifocality and Islamic teachings, and preexisting patrimonial and hierarchical networks (Aspinall 2009a, 2009b, 85-97; Abdulah 2018; Kunz et al. 2018).

An early, much referenced, colonial anthropological account of Aceh acknowledges that Acehnese matrifocal adat customs have in fact reinforced a notion of 'male marginality' in the domestic sphere. Snouck Hurgronje, scholar of 'Oriental cultures and languages' and advisor on 'Native Affairs' to the Dutch colonial government of the Netherlands East Indies, famously remarked in his research on Aceh that men feel like 'guests in the house of their wives' (Hurgronje 1906, quoted in Siegel 2000 [1969], 52-56). Hurgronje was commissioned in 1891 to 'make a special study of the religious element in the political conditions of that country' (Hurgronje 1906, v), on the basis of time he had spent in Arabia (1884-1885) and 'an intimate knowledge of the influence of Mohammedan fanaticism upon the obstinate resistance of the Acehnese on the Dutch rule' (ibid.). In his volumes entitled 'The Atjehnese', he makes observations of Acehnese homosociality, that is, social bonds between men, but also of the hierarchy between lowlanders and highlanders: ${ }^{7}$

The Acehnese colonists ${ }^{8}$ on the East and West Coast who live there sometimes for years at a time in a society where there are no women, develop every vice of the nation to its highest pitch. The true highlanders 
are reputed not indeed more virtuous (for with them theft and robbery are the order of the day) but less weak and effeminate than the lowlanders. Among them opium, drink and unnatural crime exercise less influence than in the coast provinces. Unreasoning fanaticism, contempt for all strangers and self conceit are all more strongly marked in the upper country than in the lowland districts, which have grown somewhat 'civilized' through contact with foreigners. The highlanders esteem themselves (and the lowlanders do not deny it) braver men than their brethren of the two remaining 'angles' (sagöe) of the country. A hero is in common speech as well as in literature, often spoken as aneu' tunòng kruëng = 'a son of the upper reaches of the river'.

Hurgronje 1906, 33-34

In fact, American anthropologist John Bowen has argued that the strong social construction of male (merantau/migration) and female (village) spheres as opposites was also part of the gendered discourse of the reformist Islamic movements in the early decades of the 20th century. Constructs of male masculinity attempted to transcend matrilineal village life by focusing on self-mastery, worship and economic success through migration (Bowen 1997, 174-175). Even today, residential systems in some parts of Aceh (Aceh Besar and Pidie) are uxorilocal or matrifocal, that is, the husband moves into the wife's village after the wedding, and the property is in the name of the wife, inherited from her maternal family (Siegel 2000 [1969]; Siapno 2002). ${ }^{9}$ Villages comprise clusters of houses that are owned by sisters and nieces, and similarly rice fields near the house are passed to daughters (Siegel 2000 [1969]; Siapno 2002; Reid 2005). After puberty, sons are not expected to sleep in their maternal house, but in the communal hall of the village. Young men and adolescents often leave their homes for religious studies, and adult males are frequently away trading and migrating for work, leaving the women in charge of the household. Yet, much of the historical constructs of masculinity is yet to be researched, drawing on manuscript literature that is only now being republished, annotated and analysed (see, e.g., Abbas Kuta Karang Aceh Dar al-Salam 2017 [1853]). Locally researched and published works on Acehnese masculinities, remain underrepresented in the global 'extraversion' of knowledge (see, e.g., Connell 2014) and thus, there is a need to theorise and challenge the theoretical hegemony of the Global North as part of the economy of knowledge production. These unpublished, only locally available studies confirm that major sites for socialisation of heteronormative masculinity include family, peer group, Islamic educational institutions and, in particular, Quran reading groups and coffee shops (for one of the very few locally conducted and published research studies, see Rasyidah et al. 2016). Parenting is considered essential for constructing hegemonic masculine ideals, and increasingly so for urban populations and aspiring classes in which the expectation of a permanent job and earning stable family income is prevalent (ibid.). 
Expressing these classed traits is highly supported in the public sphere and social spaces (see Chapter 3, discussing norms and expectations of femininity), and by the development plans of the provincial government: the Government of Aceh's Mid-Term Development Plan for 2007-2012 located youth as a measure of its progress, while the nation was considered under threat of 'unemployment, moral decadence, free sex, use of narcotics and criminality' (Gubernur Provinsi Nanggroe Aceh Darussalam 2007, 38). The plan admitted that the conflict and the tsunami have caused a decline in young people's productivity and role in development activities, and thus extensive physical and mental rehabilitation and reconstruction were considered essential (ibid.). The next development plan, for 2012-2017, specifically addressed the question of youth's not following religious norms or adat, and the impact of globalisation (Pemerintah Aceh 2013, 76). Urbanisation was considered to play a negative role in shaping the 'quality of youth in Aceh': former village youth without access to feasible jobs became unemployed and involved in criminal activities (ibid., 84-85).

It is argued that these two sides of the coin, attaining success and not living up to society's ideals, result in social-psychological pressure and violent behaviour (Fulu n.d.). As always, however, making such generalisations about masculinities dismisses the potential intersections of class, ethnicity and urban/rural differences, and the macro political economics at play. Ethnographic focus on lived masculinities, as Inhorn $(2012,15)$ suggests, can unsettle these dominant constructions that rely on the idea of domination and patriarchy, allowing a more nuanced reading of negotiation, and resistance to violent and dominant forms of masculinity that intersect with economic, political and social class.

For example, the decade of tsunami reconstruction also marked an important emergence of new urban-based movements aiming to diversify, and challenge, hegemonic forms of (urban) heteronormative masculinity. Such space, including a temporary opening for queer and non-conforming genders, was created under the auspices of the Gender Working Group network and local women's empowerment NGOs (Fulu et al. 2013, 58; Jauhola 2013; see also Chapter 6), and a group of men organised themselves into 'Men for Gender Equality'. Yet, as this chapter aims to illustrate, masculinities in urban Banda Aceh cannot be generalised or simplified. Alternatives or 'subordinate variants' (Cornwall 2017, 33) to hegemonic masculinities exist across intersections of class, ethnicity, age and gender expression, but may change dramatically depending on individual life trajectories related to health and ageing, or economic and social well-being.

This chapter argues that Acehnese are, and have been, reflective about their gendered histories and norms in the course of their everyday practice and mundane lives, as intergenerational resistance to colonialism illustrates. Such spaces for resistance and critique towards imposed masculinities are not restricted to a political or economic elite, or educated 'men for gender equality networks' that were established by the local and Indonesian tsunami aid workers (Jauhola 2013). Rather, it is up to scholars and activists to fine-tune their ability to locate 
and communicate such forms of resistance in a more nuanced and contextualised way. In this chapter, this form of nuanced analysis is practised by focusing on a single life historical story, while taking advantage of the perspective of the 'living archive' (Agathangelou 2017), which, according to Agathangelou, offers possibilities for reorienting oneself to emerging decolonial horizons, corporeal insights and practices that challenge toxic masculinities (ibid.).

During the Scraps of Hope documentary recordings on life in December 2016, the Sufi healer described his knowledge, and the craft of traditional medicine, as Ilmu Bodoh, foolish knowledge. As I discuss elsewhere (Jauhola and Bolong 2017), this description could be read as an internalisation of colonised subjecthood or distorted thinking, voluntarily embodying the position of 'uncivilized other' (Uddin 2011). However, I suggest that, instead, these ethnographic encounters are ways of expressing mundane resistance and subjugated knowledge praxis that go easily unnoticed. These are his strategic positions in front of the camera as a narrator of his life on his own terms: he is making visible his life experiences and Acehnese and Islamic vernacular knowledge systems - crucially important for him both during and post conflict - but only to the point where he feels comfortable. Life experiences such as his are discussed in this chapter through situated masculinities in the context of the armed conflict and hegemonic GAM masculinities during the first decade of peace. However, such examples are also located elsewhere in the city, as the following two chapters - Chapter 5 on the punk and metal scene and Chapter 6 on queers - further illustrate.

The rest of the chapter unfolds in the following way by examining the story of an ageing ex-combatant who joined the ranks of GAM in 1976, the main character of the Scraps of Hope life history videos (From ex-combatant to Sufi healer 1-3, Videos 9, 10 and 11). It begins by focusing on his reflections of changing masculinities, then visits his past in the form of practices of premanisme or gangsterism in the city among men who showcase their power through extortion, fear of violence and patron-clientelism. The third and final section of the chapter outlines a subjugated knowledge of vernacular forms of reconciliation, care and healing that are connected to the tradition of oral transmission of Acehnese and Malay Islamic practices of medicine: the Kitab Mujarabat (book of recipes, in Arabic - 'tested' or 'tried and true'), as the Sufi healer named them.

\subsection{The Long Journey from 1976 to 2016}

Three videos From ex-combatant to Sufi healer, (Videos 9, 10 and 11) focus on the story of an ex-combatant and Sufi healer in his home/coffee shop on a busy street of Banda Aceh. Three stories focus on masculinities, healing and poverty and its connectedness to armed struggle, and political leadership during the peace time.

When we were at the sea we were in harmony. So when reaching the shore, do not change it. There must be reciprocity between us as humans. (Scraps of Hope recording, 6 December 2015/0009mp4) ${ }^{10}$ 
Right now, for our family, we had to start from zero. There is no capital available for us. Our house was burned. That's the reality for us, living in a hut of misery. But although outsiders see us like that, for me this is a palace of happiness. No one troubles us. (Scraps of Hope recording, 6 December 2015/0005.mp4)

On a busy, commercial road in Banda Aceh that bustles with car and motorbike traffic, there is a simple, wooden coffee-shop-cum-dwelling squeezed between restaurants, bakeries, banks and branded shops selling items from shoes and fashion to motorbikes and sports equipment. The makeshift cafe consists of a simple terrace with tables and chairs for customers, kitchen-cum-coffee preparation sink and tiny spaces separated by plastic sheeting for personal hygiene, prayer and sleep. The tin roof is leaky and covered with old cardboard boxes to protect residents and customers from the rain. Plastic sheets and heavy wooden planks are used to demarcate the coffee shop's opening hours according to the daily prayer schedules, although the boundary between private and public, open and closed, is flexible, and friends, family members and regular customers drop in even if the coffee shop seems closed.

I initially visited the coffee shop accidentally: I was craving a cup of coffee, my favourite place was closed and as it had started to rain I had to seek shelter. Over the years, it became the place where I would drink coffee and read the daily news, and eventually teach and play English word games with the proprietors' primary-school grandchildren who lived next door. In the past, such coffee shops were numerous in both urban and rural Aceh. These light, low-cost, wooden kiosk-style constructions have been important gathering points, especially for adult men, in most neighbourhoods and villages, forming important spatial anchors for constructing Acehnese masculinity (Aspinall 2009b, 93; Jauhola 2013). Yet, the ongoing urbanising transition of the city after the tsunami, coupled with a growth in middle-class consumerism, has meant that up-market coffee shops with espresso and milk foam machines and baristas are becoming increasingly popular among the younger and wealthier class, and the gender dynamics have changed: mornings are often given over to middle-class families with small children.

This coffee shop is run by a married couple in their 60s who have occupied the plot of land since they took refuge from the armed conflict in one of the coastal districts of Aceh roughly 15 years ago. ${ }^{11}$ Their house was burnt down and the land around the ruins is now used by others in the village for vegetable growing - a common, non-capitalist, community practice of sharing the products of the land. The city around the coffee shop is changing rapidly. Intensified land use for commercial purposes and facelifts orchestrated by the municipal government have meant that people in similar circumstances nearby have either removed their belongings and self-built structures or had them destroyed by the civil service police or public order officers. In fact, this couple consider themselves lucky that the current owner of the land has not, so far, evicted them or demolished their premises. The uncertainty of their future, however, is repeatedly iterated in our discussions. 


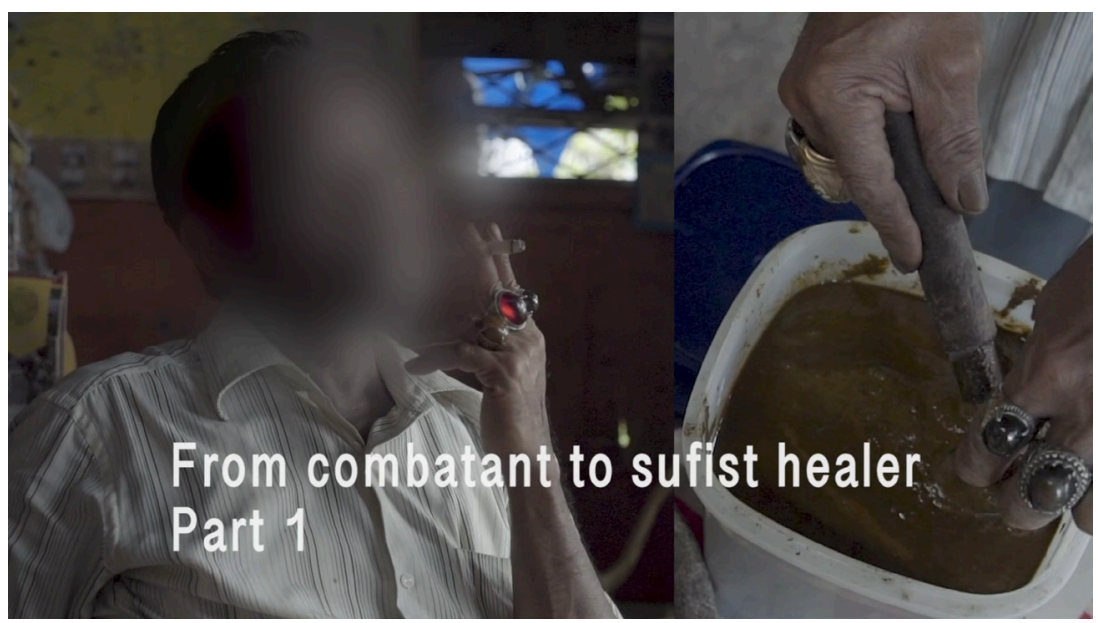

Video 9: From ex-combatant to Sufi healer 1 (08:21).

Source: Scraps of Hope.

To watch this video, scan the QR code with your mobile device or visit DOI: https://doi.org/10.33134/pro-et-contra-1-video-9

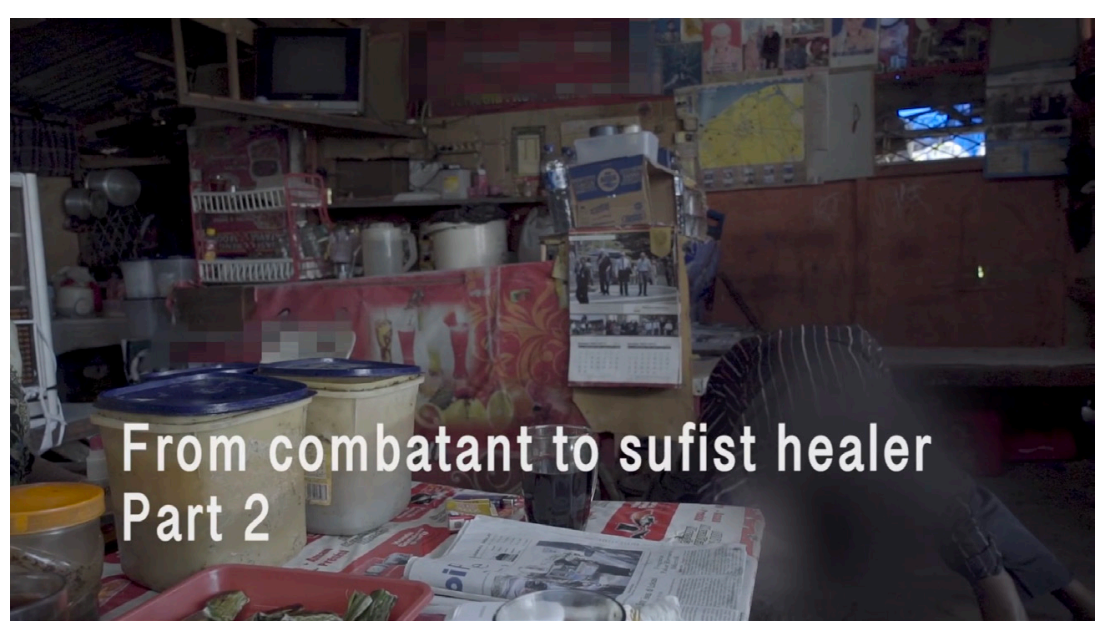

Video 10: From ex-combatant to Sufi healer 2 (05:55).

Source: Scraps of Hope.

To watch this video, scan the QR code with your mobile device or visit DOI: https://doi.org/10.33134/pro-et-contra-1-video-10

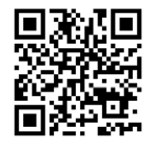




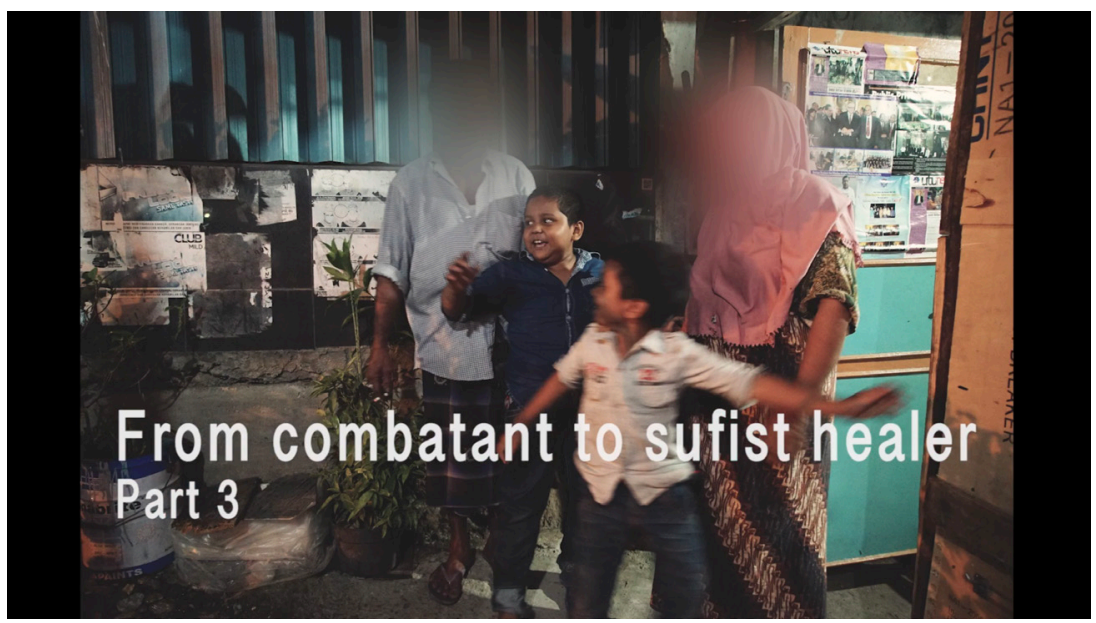

Video 11: From ex-combatant to Sufi healer 3 (05:44).

Source: Scraps of Hope.

To watch this video, scan the QR code with your mobile device or visit DOI: https://doi.org/10.33134/pro-et-contra-1-video-11

No formal tsunami housing aid has reached them, although their self-built structures were damaged and the provision for free housing was extended to cover those depending on rentals (Fan 2006, see also Fitzpatrick 2008). When the tsunami waters washed away their previous coffee-shop-cum-home, they took refuge further from the coastline, as did all other survivors: first in tents, and later in barracks, meanwhile returning to repair their shop as soon and often as possible to ensure that it would appear to be still permanently occupied and used. Their oldest son remains without regular cash labour and lives outside the city, although he and his children are regular visitors, bringing vegetables, eggs and snacks to sell in the coffee shop. The couple's only daughter is married, with three children born after the tsunami, and she lives with her family in a similar makeshift house squeezed between two older residential houses, just behind her parents, which is built from wooden planks, plastic and tin-roof sheets. She runs a small kiosk with her husband next to the coffee shop and her children spend most of their time after school in the street or visiting their grandparents.

Over the three years of my regular visits to the coffee shop, the fluctuation in the family finances became evident; they also had to contend with the constant flooding, strong winds and rain that torment their premises, the powerful smell of sewage, and the worn and broken furniture. The coffee shop had fewer and fewer customers and, in a concrete attempt to increase the cash available for 
the extended family, the wife started to recycle plastic and cardboard boxes (see Chapter 7 for details). I was told of this with some embarrassment, as there is considerable stigma attached to garbage collection and recycling. Yet, these earnings are vital to ensure their grandchildren's education and to cover their own medical costs, as they both have chronic optical health issues and constantly aching bodies. Later, they would combine the coffee shop with a traditional healing practice, the reputation of which was growing at the time the Scraps of Hope recordings were made.

On one visit in 2012, I watched as the husband hung photographs on the walls of the coffee shop, thereby producing a non-verbal, yet emphatic, exhibition and remembrance of the armed conflict and the markers of his identity: a coffee shop advertisement that replicated the colours of the GAM/Partai Aceh $^{12}$ flag; an enlarged ID-card photograph of him in combatant gear placed high up on the kitchen cupboard; and old calendars with photographs of the MoU signing ceremony in Helsinki in 2005. Later, in 2015, at the time of the video recordings, new clippings from the local tabloid newspapers were used to decorate the newly built wooden divide and door between the customer area and the kitchen. Still around 2012, the coffee shop provided a space for other ex-combatants to discuss ongoing political and economic transformations and business opportunities. Yet, when alone, the owner gave his own, slightly differing, account of the peace process in Aceh. He was no longer party to the inner circles of ex-combatants who had financially secured their lives through contracts and new businesses, or as thugs 'taxing' businesses (known as pajak Nanggroë), which was argued to constitute infaq ${ }^{13}$ (Schultze 2007, 91-93; Aspinall 2009a), even though he had belonged to the original generation of independence fighters that had joined the Forces of the Free Aceh Movement (AGAM) ${ }^{14}$ which founded GAM in 1976 (for details of early years of the indpendence movement, see, e.g., Schultze 2004; Aspinall 2009b, 64-65).

During the conflict years, GAM's coherence as an armed group was built on kinship bonds among fathers, sons and brothers, and that is how the male members were usually recruited. ${ }^{15}$ Socialisation into the movement provided a strong base for identity construction in networks of young men for whom loyalty, honour, physical bravery and risk-taking were part of everyday life (Aspinall 2009b, 92). GAM recruits were also drawn from martial arts groups, former or serving military or police personnel, petty criminals, and motorbike gangs, circles that were actively constructing a violent form of masculinity (ibid., 93-94). The GAM commanders who became famous in the local media reiterated the machismo lifestyle, wearing assortments of military and civilian clothing and holding AK-47 rifles under their jackets. Certain outfits became identified as 'GAM', which meant trouble for anyone wearing a long jacket or one made of denim. Merely wearing such clothes could mean being killed with no questions asked (ibid., 167-168).

'Who are these in the pictures?' asked the activist and poet Zubaidah Djohar of the Sufi healer in one of our recording sessions. 'They are my old friends ...' 
he answered. 'Their life is still messy ... their life is harder than mine now ... Because right now we do not know where to go to seek help whenever we have problems. During the conflict, we had our chief commander, we had our Panglima Sagoë; ${ }^{16}$ we knew where to get help from.'

Having distanced himself from the troops and the battle at the time of the death of his commander, half a decade before the peace process, meant that he was not included in the lists of combatants eligible for the reintegration funds that became available in the aftermath of the Helsinki MoU. He was considered to be an 'escapee' (Abdulah 2018, 92).

Three attempts to acquire a small business grant of 'satu juta saja' (equivalent to roughly $70 €$ ) to improve his coffee shop were never supported by ex-GAM reintegration structures:

If we go to their office, they do not know us anymore. Moreover, my appearance like this is so different from those who wear shiny shoes and who put on a tie. Suppose we go to them, they would ask, 'Who are you? From where were you? Which region are you? Which Sagoë are you from?'

In his narrations, he talked of being an outcast by means of allegories, but such allegories clearly also point towards the ex-commanders who had successfully created a 'peace industry' (Abdulah 2018, 106), such as:

The one with the loudest voice gets the bigger fish catch; the one who is silent does not get any.

During the conflict we all spoke in unison and had an agreement. However, today it's different. Different approach with clean clothes and dirty clothes, the smart ones and the foolish ones.

Over the years of being a combatant, he was imprisoned, mutilated and interrogated several times by the Indonesian army. Yet, as I describe elsewhere (Jauhola 2017), my knowledge of these experiences expanded gradually; he was a man of quiet thought. When the video camera was switched on for the first time, three years after we first met, the story focused on his major decision to withdrew from combatant structures, pointing to both personal and familial losses, but also disillusionment with what armed struggle would gain. ${ }^{17}$

This was a man who narrated his motivations to join the independence struggle with reference to the Islamic ideology of economic justice and prosperity and in resistance to European capitalist colonialism and also to the formation of Indonesian state. ${ }^{18}$ Accordingly, his interpretations of the ideology that led to armed struggle are filled with allusions to social and economic justice and the unfinished decolonialisation of Aceh (for a more detailed account, see, e.g., Schultze 2004, 6-10). This understanding of the present, viewed through 
the lens of a lengthy, historical temporality, became apparent on several occasions. One day, in passing, I was told that the land occupied by their cafe had belonged to someone who went missing during the massacre of 1965-1966, which targeted the political Left, communists and ethnic-Chinese communities (Kammen and McGregor 2012; Melvin 2014). Following the massacre, land was commonly seized from people accused of being PKI members and handed over to a plantation company that was state-owned and connected to the military. The only reminder of the past was the written sign next to the coffee shop: 'Forbidden to construct a kiosk on this land. Province of the Special Territory of Aceh.' The sign is a silent reminder of the slaughter of half a million people across the Indonesian archipelago, escalating from the initial killings in Aceh in October 1965 and leading to the flight of thousands of people to Medan, a violence-led migration pattern (Tsai and Kammen 2012; Melvin 2013).

The Sufi healer explained:

I make my own living, using this state land, the land of Dutch era. The Netherlands lost the war in Aceh; they left their wealth in Aceh, which became controlled by the government. At the moment that land protects me. I think people are kings. The government is subject to the people. The government is people's parent. No child may be expelled. Land is not to be bought, someone else's land. He who is powerful, he holds the power at the moment. That's all ... The world remains calm, quiet in eternity. If in the world, life is difficult, the eternity will also be difficult. That's all.

These thoughts were narrated as being in continuity with the aftermath of having withdrawn from the movement and escaping the violence to the city of Banda Aceh with his family. Further, his discontent with the newer recruits and forms of combatant misogynistic masculinity that prevail in Aceh was evident:

This means, you need to provide people with what suits people's needs. Those who were orphaned by the conflict, ask what they need. If they need to be schooled and educated in reciting the Qur'an, do not wait until they are old, because they are then duller than animals. That's our fault. If a wife, whose husband left her, has a beautiful face, of course there will be many who would like to marry her. However, if she looks like 'cow manure', her destiny would remain unclear. If she already has three children, she works hard to maintain and care for the three children and hopes for a new husband, that is not likely to happen, because her face was like 'bull shit'. However, if she has a beautiful face, pleasant, even before her husband has died, there are those who harass and intimidate her. These are still Acehnese characteristics. 
Five years into the peace, I observe that the government of Aceh is so different from the promises made earlier. We are now in the ten years of peace. I practise medicine the past five years. Before that I was searching for a livelihood. Went to the governor's office, intimidated civil servants, and employees of the office. They gave money, perhaps hundred [thousand] or three hundred [thousand] for the rice. I returned and acted like a hooligan (preman). When the realisation of this happened to me five years ago, I stopped it. But the challenges of [the root causes] of (armed) struggle still remain.

Yet, his anger and violent demands for justice (premanisme) had changed into observations that such a path did no good for him or his family. He added, furthermore, that the consequences of the armed struggle in Aceh had led to particular family dynamics and gendered vulnerabilities:

This is the sadness of Aceh during the conflict. Deepest sadness felt by the newlyweds. Groom went into the forest for the sake of the holy struggle. Bride stayed at home. A wife, though just staying at home, still feels the excesses of conflict. First, it is about the family's livelihoods. If there is no husband, they must earn a living. Secondly, there was absolutely no conjugal relationship. Women who stay at home during the conflict, continue to suffer today.

With a focus on Sufism and traditional healing practices (see a more detailed discussion in the last part of the chapter), he actively distanced himself from the predatory economic practice that has emerged as a form of hegemonic political economy, and hegemonic militarised masculinity in the post-conflict context; this positions him at the centre of Acehnese resistance to political economic and religious ideology. ${ }^{19}$ Sometimes, this resistance is articulated through principles of giving to those who are in need - avoiding their transformation into beggars - and resisting 'establishing a house within a house, Islam within Islam' by which he refers to the political Islam, and demands to formalise Sharia Islam into the state.

Yet, similarly, recognising the publicity of ethnographic encounters, he provides clear limits to what he is prepared to speak about:

And now, what is the work done so far? There is still conflict, what is it that he [governor] says about it? Aceh is crowded with orphans again, victims of violence. Why does no one care? ... But now, all the talk is lost. There is no point in talking even if this is the truth ... because a lot of talk will threaten one's life. A lot of talk will be considered being a traitor. It is better I live in garbage. In a shack ... but unlike like mine, the palace of the ruler is not a shack of suffering. Yet, I am still alive. 
Descriptions and reflective analysis of his everyday life make visible his struggles as an elderly, low-rank, male combatant who has struggled in poverty for the first decade of peace after being sidelined by his former commanders and resisting the predatory patron-clientelist masculinity developed by and among the ex-combatants, the focus of the next section.

\subsection{Premanisme and Conflict Presence in the Post-Conflict City}

This section focuses on the political economy of the street and how, on the one hand, it continues to be militarised while, on the other, it is governed by various types of street gangs formed at the nexus of army, former ex-combatants, individual fortune seekers and opportunists trying to make ends meet. The stories that are discussed here were collected during 'hanging around ethnography' in a public park that is formally controlled by the municipal government, but informally by preman networks (for earlier analysis of the role of premans in urban Indonesia, see, e.g.: Lindsey 2001; Aspinall 2009a; Barker 2009; Wilson 2010; Wandita 2014).

'People are afraid of my husband', a female street vendor told me one day during my last visit to Banda Aceh in December 2015 to January 2016. I had initially got to know her husband when he was serving his two-year, drug-related sentence in one of Banda Aceh's prisons. He was recruited into GAM as a young adult, dropping out of school upon joining the movement, just a few years before the 2005 peace process. With little education, no savings or possibility of getting a loan, he had turned to ganja dealing and trafficking as a means of making a living. When visiting him in the prison in 2013, he showed me leg wounds and an infected heel that were caused by an Indonesian army shooting in 2003. As the prison clinic did not have the required expertise or medicines to attend to his leg, his wife's earnings were the main source of income and she was also his courier between the prison, the pharmacist and the governor's office. After he was released from the prison in 2015, he re-established his GAM connections through the former command structures in order to gain access to a leg operation, but later became part of the ex-combatant premans who make their living through extortion, petty crimes and illegal businesses. He was rumoured to have killed people, hence his grim reputation.

After prison, he joined his wife in the park as a day-wage labourer, but he did not see that as his future. The days at the park passed in discussions of whether multi-level marketing would be the best way to economic security and success and, if so, whether water purification components, herbal medicines or something else. His moods swung between the excitement of big plans for the future, and moments of anxiety, frustration and impatience. Immersed in reflections of the past, he kept retelling tales of combatant times in the early 2000s, when American journalist and film-maker William Nelson, clearly an important 
outside alliance to him and his combatant friends, was filming the documentary Aceh - the Black Road, released in 2013. Occasionally, he was visited by a group of ex-combatants from his district, which usually generated whispering and rumours in the park; the reputation of these premans travelled widely, and very few wanted to be confronted by them. Yet, as a post-MoU migrant to the city, his networks were strongest in his home district and village, and when the leg operation was finally over, his ex-combatant commander, now head of the district, extended his economic support. This seemed a culmination point, and later he continued to draw financial support from these districtbased political economy arrangements that were no stranger to extortion and even violence.

In the streets of Banda Aceh, such formations of collectives and cooperatives were common. The park vendor rent collection, security and maintenance were handled by a group of ex-combatants hired by the municipality administration. Close by, another group, operating from a coffee shop, ran a becak, a motorbike rickshaw circle, but they also provided logistics (with provision charges) for a blind man earning his living by begging in the streets. Similarly, the traditional carts, known as pedagang kaki-lima, were organised in Banda Aceh through a cooperative, Persatuan Persaudaraan Pedagang Aceh (P3A), which in the first decade of peace, as discussed in Chapter 2, had become an important though vulnerable source of income due to municipal regulations to clean the streets in the name of beautification and modernisation of the city by regulating the cart sales in indoor markets only.

Likewise, soldiers are known to have a hand in the grey political economy, extortion and 'off budget' fundraising techniques (Aspinall and van Klinken 2010) and, for many, that capital was an essential part of the economy of renting the equipment to those vending in the public parks. These collective arrangements do provide a badly needed alternative to the insufficiently available capital for the lower economic classes, but also recreate economic dependencies that silence criticism and allow the continuation of the patron-client relations of the conflict years. These include those made by the Partai Aceh with the Indonesian army prior to the 2012 elections in order to secure their election win.

Although the migration to Banda Aceh is part of the post-disaster/conflict phenomena, grey or illegal economic activities within the city are not the only ways of ensuring livelihoods, as the government development plan for 20122017 quoted above suggests. In fact, for many people in other parts of Aceh, it was not the city of Banda Aceh that attracted labour migration and the promise of better lives, but the economic development and growth of the wider Malay coast (Vignato forthcoming). A middle-aged man making a living in the park told me about the various means of economic migration (merantau) ${ }^{20}$ during the armed conflict; he had sought wage labour in Malaysia and ended up forging stamps and official documents for migrants as a way to stay out of the conflict, but he was imprisoned for forgery. The park vending was just one of his 
many attempts to make a bearable living, made possible by the rental/economic relations with those possessing cash, equipment and new ideas, such as soldiers serving in town.

The older ex-combatant narrated stories of patron-client relations, and premanist extortion in the city, retrospectively, with remorse. The shouting and demands, going into the governor's office and demanding a share of the post-conflict wealth and prosperity, did not help him or improve the situation of his family. Yet, it was precisely this pattern that was repeated in different stories across the city. As the state welfare redistribution system, or the redistribution system of $z a k a t^{21}$ payments under the umbrella of the Baitul Mal organization, ${ }^{22}$ was unable to reach all those in need, writing letters to the political elite and queuing to see them to request compensation for unjust losses was common.

One day, when I sat reading a newspaper at the old Sufi healer's coffee shop, a man in his 60s parked his motorbike out front. He took some papers from the seat compartment and walked in. I recognised him as a regular customer of the shop and soon realised that this time he had come in to share his conflict story with me. He handed me several letters addressed to the governor in which he pleaded for the recognition of his position as a former primary school teacher as part of the ongoing peace process, requesting some of the compensation earmarked for conflict victims. His formal (Indonesian) state bureaucrat contract as a teacher was terminated in 1999 as he had subverted the official Indonesian history syllabus by teaching history from an Acehnese nationalist perspective. The history of Aceh had been his dissertation focus 10 years earlier, when he rewrote the history of Aceh by focusing on the 17th century and the reign of Sultan Iskandar Muda. Since the termination of his employment, he had made a living by providing transportation for travellers going to the city bus terminal. 'Aceh is like a mountain looming afar. From afar it appears beautiful and graceful, but when you get closer to it, you notice that on those hill's trees are partly fallen and in bad condition', he told me. It is through local idioms and symbolism like this that realities of everyday life were often portrayed to me: the disillusionment that had followed promises made in election campaigns and high politics. He had sent dozens of letters to governmental offices since the signing of the MoU in 2005, requesting the state pension to which he was entitled. So far, there had been no other response beyond a letter from the vice-governor in 2012 in which the absence of progress in gaining a formal response from the provincial government was confirmed.

\subsection{Subjugated Non-Violent Masculinities - Oral Transmission of 'Kitab Mujarabat'}

This last section revisits the city from the perspective of how intensified urbanisation and globalisation, new economic and social insecurities, and pressures 
on legitimate - or hegemonic - masculinities are negotiated through Islamic and Malay healing praxis. Such praxis can be read as an alternative or resistance to formalised institutional correction and governing of masculinities through positive law (see Chapter 5), Islamic jurisprudence and adat (Kloos 2017). In a global media circuit, these institutionalised forms consist of widely publicised caning punishments that predominantly target illicit sexual relations and sexual violence (see Chapters 2, 3 and 5), but also gambling and alcohol (Jauhola 2013), and decency, gendered expression and homosexual behaviour (see Chapters 5 and 6).

However, as this section will show, the Sufi healer and his healing praxis is not only a manifestation of post-conflict dynamics that derive from the positionality of a lower-rank combatant (see also Abdulah 2018). Such praxis is connected to his original motivations to join the independence struggle and is integral to the Islamic ideology of economic justice and prosperity; it also represents resistance to European capitalist colonialism, the formation of the Indonesian state in the late 1940s and, more recently, the Shariatisation of Acehnese state structures. As discussed elsewhere (Jauhola and Bolong 2017), such a focus on the everyday facilitates the locating of power relations and resistance to hegemonic forms of gendered subjectivities, or being an Acehnese man, in a continuum of decolonising masculinities.

'You should join us! We will invite all our neighbours on the anniversary of the death of my husband ... It is to make sure that the violence of that man is not continued by my son.' So spoke the mother of one of the punks of the museum street punk community (see Chapter 5) when I was visiting their house one day. This event or ritual, originating in the Gayo region in Aceh, ${ }^{23}$ is practised once a year by this family since the death of the father, who had been a government official - meaning a steady income for the family. Yet, there was an element of the bitter-sweet in his death, as narrated by both the now adult/ young adult children and his widowed wife, because it had relieved them of the fear of his temperament and physical abuse. Watching her son disappear onto the streets of Banda Aceh, visiting him at the police station, the court house and the prison, while living in economic hardship and with diabetes - a disease that she says her family cannot afford - meant that the family used any means possible for guiding the son back to the path of becoming a responsible breadwinner for the family.

This was the first time during my research in Aceh when I encountered traditional healing or ritual practice, practices of care, targeting men and the control and correction of violent masculinities. ${ }^{24}$ Intertwined with the practice of religion, the Sufi healer explained:

It is Allah who cures, not me. If someone is sick, it is not me who heals. And this is not just for Muslims, but also for Christians. Creations of God. The same with Hindus; all are creations of God. All that exists: trees, stones and leaves are creations of Allah. 
How can a leaf of a tree turn into oil that heals? It cannot be told. That is nature's secret. If we speak about it, it no longer can heal. It's like that, just like wisdom. If we become vain, if we go on about it, it becomes egoistic.

Those leaves become medicine ... It has helped [us] in crisis. Almost all understood leaves, quality of this leaf. All friends understood this, during the struggle. They understood the outcome. Many died. Now those who died are already in peace; young ones died back then. The ones who are young now, I don't know them. What was done during those years, that's what cannot be spoken of.

As he says, traditional medicine was an important way for the independence movement and the troops in the forest to care for the wounded by preventing bleeding and so on. Such roles are often mistakenly documented in postconflict literature as having been performed by non-combatants, such as the wives, daughters and mothers of the soldiers (Vastapuu 2018, 43). However, as described by the Sufi healer, this is a skill that he learned from his older brother, mother, father and grandparents, and used during the combat years. Practising such forms of therapy (oil massage, smoke and heat treatments, blended herbal drinks) requires certainty, as he describes it. He told me that this knowledge, although transmitted orally in his family, is derived from a book called the Mujarabat. In the Acehnese manuscript tradition, there are a number of different sources from which medicinal recipes, curing and healing practices connected to those of Islamic medicine and Malay traditional healing traditions are drawn. ${ }^{25}$

Yet, the importance of the Mujarabat is not restricted to health understood as symptoms and diseases; rather, it offers holistic guidance also applicable to post-conflict reconstruction, leadership and politics:

For example, $\mathrm{X}^{26} \ldots$ he is part of my family. Still my family member, my cousin. But why I am no longer close with him? He has broken the promise [of the Mujarabat]. The religious community who denies the promise is a hypocrite. God is not happy to observe his servants like that. That is all.

After the parliamentary elections of 2014 when the Partai Aceh, the party established by the ex-combatants, lost its majority seats in the provincial government, the Sufi healer redecorated the cupboard wall with new, enlarged, laminated photographs of himself and a number of his deceased heroes: the founder of GAM, Dr Hasan di Tiro; charismatic Naqshbandi Sufi ulama Abu Ibrahim Woyla from West Aceh; GAM-aligned ulama, Teungku Muhibuddin Waly; and Abu H. Abdussamad bin Usman. The text in one of the photos read: 
O Allah show us, Acehnese people, the right path and give us the opportunity to care for the welfare of our grandchildren with the wealth that had been left by our ancestors.

May Allah bring peace and blessing into your life and home!

\subsection{Ilmu Bodoh - Healing as an Alternative Political Economy?}

This chapter has elaborated on ethnographic encounters with urban masculinities and the ways in which they are performed and negotiated as part of the ongoing peace process, addressing violence, care and healing, and their connectedness to postcolonial continuities of economic and social injustice. The chapter followed the life history of an ex-combatant/Sufi healer who had joined the armed struggle as a young adult. It revisited contemporary urban encounters with violence and the preman gangs which had also been part of his past, and elaborated on subjugated archives of vernacular forms of reconciliation, care and healing - his current livelihoods and ideological foundation.

This chapter suggested that what he calls foolish knowledge (Ilmu Bodoh) is, in fact, a narration of a lived archive with a decolonial past and a horizon in the future. Drawing attention to such ethnographic encounters, it was argued, forms both an ethical and a methodological understanding of how masculinities always intersect with historicity, context, class, age and feelings of one's own and one's family's security. Following the knowledge transmitted orally from generation to generation, the continuities of the struggle for economic justice and prosperity through Malay traditional medicine and Islamic practice provide openings to an understanding of vernacular and non-institutionalised resistance to both European capitalist colonialism, and also to the formation of the Indonesian state and the politicisation of Islam and Shariatisation. The focus on the daily praxis of healing distances the Sufi healer from the predatory economic practice that has emerged as a form of hegemonic political economy in the post-conflict context, positioning him at the centre of Acehnese resistance to political economic and religious ideology, often articulated through principles of giving to those who are in need, and resisting the formalisation of Sharia law. 



\title{
Chaotic Pavements
}

\section{Punk/Metal Scene Keeping the Traumas of the City Open}

\subsection{Bastard Illiza ${ }^{1}$ and Punks' Politics \\ of Repression in Banda Aceh}

\author{
You bitch have ruined \\ Our mission and ambition \\ The bitch is holy \\ But hypocritical and malicious \\ Your life is full of \\ Hypocrisy and greed \\ You want fucking die \\ You want fucking ashole [sic] \\ Illiza bastard ${ }^{2}$
}

City and Sharia Police are licker dogs for you

In this chapter, the former (vice) mayor of Banda Aceh, and the piety politics of her governance discussed in Chapters 2 and 3, are approached from a punk perspective. 'Bastard Illiza' (in Indonesian, Illiza bastard) is a punk song by Banda Acehnese punk band Botoel Kosoenk (in English, empty bottle) which circulated as a song, but also as a patch (Image 7) sewn onto the trousers and jackets of Banda Acehnese punks. Both the song and the patch were a punk response to, and commentary on, the punk and metal band arrests and detention in a 're-education' camp in December 2011, which was orchestrated by the female vice- mayor of Banda Aceh, Illiza Sa'aduddin Djamal, in collaboration with the municipality's Sharia and Civil Police (Satpol PP and WH), police 


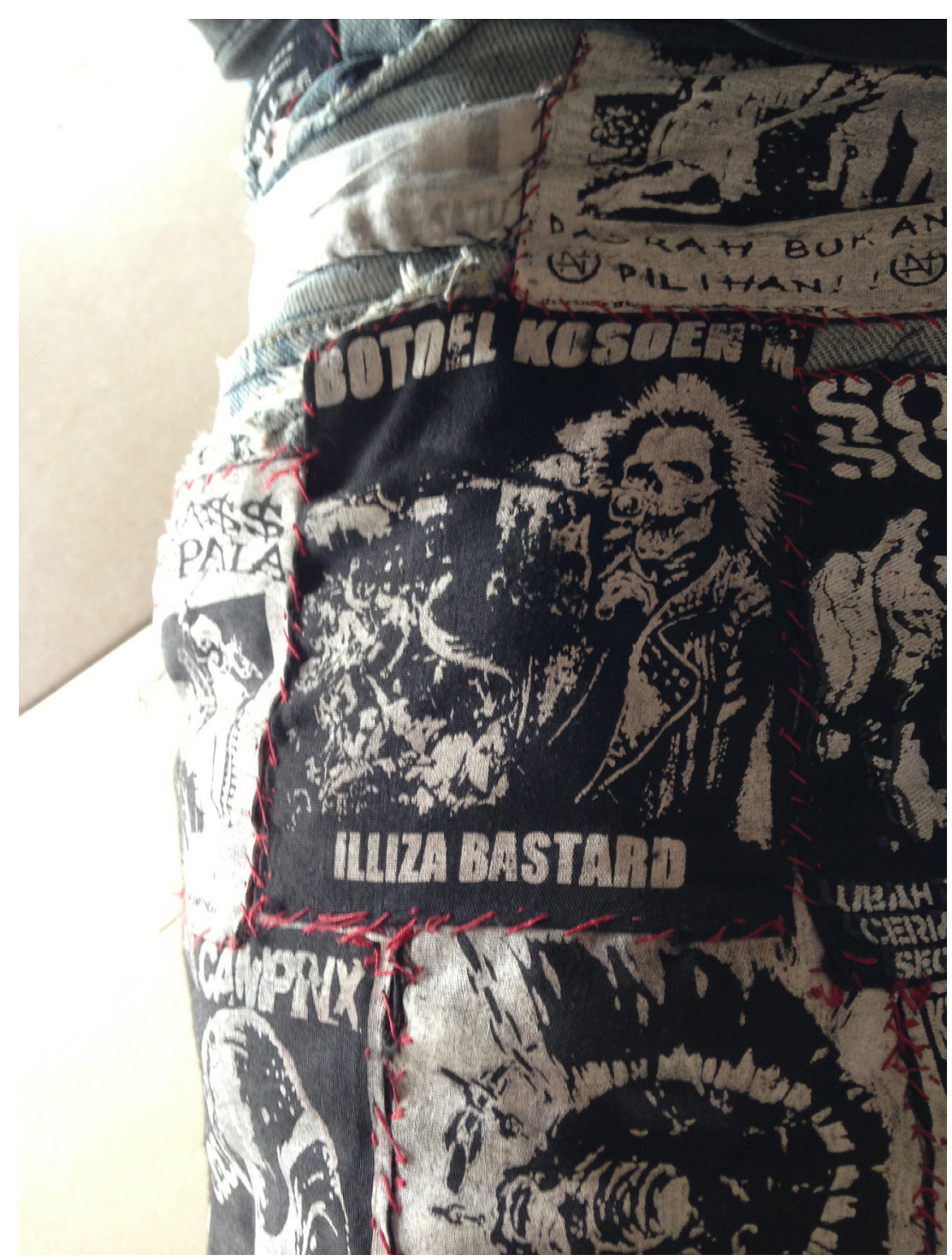

Image 7: Illiza bastard.

Source: Marjaana Jauhola.

force and military. On the evening of 11 December 2011, 65 punks (62 males and three females) ${ }^{3}$ were arrested in Banda Aceh at Taman Budaya, an openair cultural event venue administered by the municipal government. The event was followed by tens of punks and metal fans from different parts of the province, but also from Northern Sumatra and Jakarta. All in all, some 15 bands were scheduled to perform, and formal permission for the event had been 
applied for and granted by the municipality's administration and the Ulama Consultative Assembly (MPU). Using a commonly known strategy to obtain official permission for such a public event (Idria 2013, 189), it was explicitly advertised by the local organisers as a charity event aiming to support orphanages in Aceh.

The arrests led to three days of detention at the Banda Aceh police station and then a further 10 days of 're-education camp' or 'moral rehabilitation' at the police academy compound in the neighbouring district of Greater Aceh (Aceh Besar). It was not the first punk arrest in the city. Rather, it took place after the local police had officially banned 12 local punk communities by publishing a list of prohibited groups in the local newspaper Serambi Indonesia (Idria 2013, 195). As the December 2011 arrests and detention coincided with the campaigning period for the 2012 mayoral elections, they were narrated by the members of one banned group, Museum Street Punks, not as a coincidence, but rather as a carefully planned intervention to discipline 'out of control' bodies and practices that were claimed to be incompatible with Acehnese and Islamic culture (Idria 2013; Syam and Hasan 2013).

Both the global, English-speaking media and local government rhetoric over the weeks and months following the arrests portrayed the events of December 2011 in well-rehearsed binary interpretations of the implementation of Shari'a law in Aceh. The international media framed the story as a crackdown on punks in the name of Islam. For example, Voice of Asia (Lamb 2011) called Aceh 'super conservative': 'Aceh is traditionally more conservative than other parts of Indonesia. The province adopted partial Sharia law in 2001 as part of an autonomy package aimed at quelling separatist sentiments'; the word punks was placed within quotation marks. The local media and authorities in Aceh repeated the story of punks being a Western phenomenon, inherently alien to Islam, and thus to the Islamic and Acehnese way of life and culture (for a more general discussion on punk and Islam, see, e.g., Fiscella 2012). The authorities further constructed their and the state's responsibility to act using the language of concerned parents. For example, the police chief reasoned: 'they are our nation's children ${ }^{4}$ who need to be saved' (Anon. 2011).

Once the punks were arrested and detained, local journalists and photographers accredited with international news agencies (such as AFP) were let in to document the spectacle of their re-education in akhlak (Islamic character), although local human rights organisations were denied access to the premises. In fact, the wide documentation of the mass arrest by local media, and later of the re-education camp by global news agencies, suggests that authorities had invited the media to bear witness to the unfolding events. Consequently, in just three days, the arrests and re-education gained international media attention, leading to multi-sited punk solidarity campaigns across the globe, and increasing punk tourism to the region, discussed and documented widely both in and outside of punk studies (Idria 2013; Jauhola and Bolong 2014; Donaghey 2015; Idria 2015; Jauhola 2015a; Dunn 2016; Donaghey 2017; Jauhola and Bolong 2017). 
The mass arrest and the re-education camp became an international performance of repression of punks, state violence and authority, yet they also illustrate a wider contestation of political and legal power in Aceh (Kloos 2013, 225-226, 234): the negotiations between multiple and coexisting legal and moral realms. They also heralded a change in moving the responsibility for dealing with the transgression of social norms from the sphere of family, and the village or neighbourhood (adat), to the state: in this case, to the mayor, who was assisted by military and civilian state security forces - parties that are formally mandated to maintain order and the mainstream implementation of Shari'a law (for a similar case of 'restoring moral order', see Kloos 2013, 220-223).

In the media coverage that followed, Vice-Mayor Illiza specifically elaborated her maternal feelings to demonstrate her concern and justify her firm action: 'as a mother I feel very bad to see a child behave like that' (Jinnmonkey 2012). By expressing her affects, she made the connection between her maternal emotions, her mayoral position and her candidacy for the gendered state ideology of State Ibuism (Suryakusuma 1996), discussed in detail in Chapter 3. In this construct, these maternal and governmental desires are linked to normative assumptions of women's roles and duties as mothers - as bearers of the future generations of Acehnese citizens - and their moral duty to act. The latter was further elaborated at the release ceremony at the police academy, where the wives of police officers, dressed in their formal pink uniforms (see the discussion of the gendered state and the function of women's organisations in Chapter 3), played a crucial role.

They've become our recreations, truly we have reconstructed them. Staff here just developed [their character] over the past week to be pure; they've acted in a friendly manner with us; they've made poems. They surely have potential and it is up to the government to ensure the process continues and spreads to make it constructive.

Regional Police Chief for Aceh, Iskandar Hasan in Sahendra 2011, emphasis added

Thus, the event became a spectacle of the reconstruction by the state of heteronormative masculinity and femininity at the same time as it demonstrated the successful reconstruction of punks into respectable and religious, yet also militarised, citizens. The re-education, reflected upon by the punks afterwards, had included shaving their heads, confiscating their punk clothes and providing them with military outfits (boots, hats, shirts and trousers used by the police academy students) and clothes considered appropriate when performing prayers. The militarisation was symbolised at the graduation ceremony where the punks wore their military outfits, performed drills in front of the police officers and their wives, and celebrated the success with a singalong (see also 
Chapter 3) of famous Indonesian love songs. The poems mentioned by the police chief, and sung in front of the police academy staff and their spouses, were in fact famous punk songs sung across the Indonesia when punks busk with ukuleles, such as 'Cheap film' ('Film murahan', discussed in later sections of this chapter) and 'My Aceh, do not cry' ('Acehku jangan menangis'):

\author{
My country's fertile and prosperous land \\ Gathering of civilization \\ Mass slaughter does not stop \\ Take away independence \\ Tears do not stop \\ Dripping \\ Wet the earth of this country \\ A thousand innocent lives \\ Were massacred by the tsunami \\ My Aceh, do not cry \\ Your wounds are our wounds \\ My brother do not grieve \\ Your wounds are our wounds \\ Your wounds are our wounds \\ 'My Aceh, do not cry' ('Acehku jangan menangis')
}

This particular song, I suggest, makes post-tsunami experiences in Aceh, such as those of the punks, intimately part of the grieving in the aftermath. So, instead of following the sentiments of the tsunami aid/reconstruction slogan, 'Aceh that is built back better', which suggests that the traumas and experiences of the tsunami have been resolved and have reached closure, the song, 'My Aceh, do not cry', keeps the trauma and violence of the aftermath open and in circulation (Väyrynen 2013).

The performance of state power, embodied and vocalised through a concerned and motherly executive and a fatherly police chief, did not formally fulfil any of the legal requirements of arrest or detention that are positive law in Indonesia, as noted by Aceh human rights lawyers interviewed by the international news agencies. However, as in most post-colonial states and like the rest of Indonesia, Aceh formally follows a pluralist legal framework in which local customary $a d a t^{5}$ law is considered a source of law, along with religious law and positive law. As Michael Feener in his study of Sharia and social engineering has noted, at times adat sanctions for offences have included forcible submersion into filthy sewer water, beating with wooden clubs and public humiliation (Feener 2013, 176). Thus, it seems that both the vice-mayor and the police force were extending their roles into that of adat moral education and control, as well as framing their conduct as acts of affection. Once released, the punks rejected this, turning the vice-mayor into a skeleton (Image 7). 
Using words such as bitch and bastard in 'Bastard Illiza' constitutes a direct confrontation and could be simply read as misogynist epithets for a successful female politician. Yet, the lyrics go beyond that, pointing towards the necessity of 'licking dogs', that is, the Sharia and municipality police, if a female sovereign is to maintain her power in the current context of Aceh and political Islam. As discussed in Chapter 3, the lack of such support meant the end of her mayoral term. During her last and unsuccessful campaign in 2017, it was the conservative voices that turned against the idea of female leadership, arguing that it was un-Islamic for a female to lead. Although they are more upfront with their critique of state violence and repression, Acehnese punks are not alone in pointing out the hypocrisy and greed of elites. In fact, over the past years, the criticism of corruption and neglect of poverty is not only thrown in the faces of the political elite during demonstrations, but also when they have directly interacted with street vendors (Habadaily 2016).

In sum, it seems that the use of symbols and the focus on religious and political hierarchies follow globalised forms of punk and anarchist expression across the globe (Willems 2014). Yet, as I show in this chapter, besides identifying such global commonalities, it is equally important to focus on locally expressed sub-cultures to gain insights into the benefits of becoming, or being, a punk in the specific context of post-disaster and post-conflict reconstruction - culturally, socially and religiously. Simultaneously, such a focus offers a way to analyse the consequences of the imagined and desired transformation of mostly young adult males, in times of building the city anew. The chapter also visits the metal scene of Banda Aceh, which gained very little attention in the global punk solidarity campaigns, yet which seems to have negotiated peaceful and less confrontational space for its existence. This chapter argues that paying attention to the mundane and the detail, 'studying up' governmentality through punk and metal ethnography (Bolong and Jauhola 2017), provides insights into the gendered body and its negotiation vis-à-vis a city's changing moral and legal context. The chapter follows forms of maintaining the punk and metal city when confrontational and visible expressions of punk homosocial relations are violently controlled locally; it moves out of the city to social media communities that form a rhizomatic punk and metal cityscape globally, exploring agency and the inherent mobility and moulding of the self. Such 'strategic collective performance', using Pabón-Colón's (2017) re-conceptualisation of Spivak's notion of strategic essentialism, aims to appreciate the effects of specific events 'as minoritarian methods for visibility and empowerment' (ibid., 178).

The rest of the chapter offers insights into the lives of street punk and metal communities in Banda Aceh. It follows their lives from the Tsunami Museum and burger street cart to the prison and court house, from punk community to Islamist movement and back, from their tattoos to their songs and lyrics describing Acehnese post-conflict realities in which impunity, corruption and militarised everydays are embedded, and also examines the transnational online punk and metal community. The first two shorter sections discuss the 
importance of the collective wound of the tsunami actively used by the punk community in Banda Aceh to frame their bodied selves in the city and forge connections to wider punk visibility in Indonesia, and the ways in which punk homes are rhizomatically constructed and contested. The third and longer section analyses the functioning of the rule of law in Aceh through a punk arrest case known as the 'Rex incident', while the final section introduces the lesserknown metal music scene in the city through a trash metal band, Cronic (in English, Chronic). Whereas Chapter 4 focused on Sufist traditions, arguably a set of knowledge practices and embodied ways of dealing with illness, violence or its traumatic aftermaths, this chapter focuses on similar types of spaces offered by the city's vibrant, yet contested, punk and metal scenes.

\title{
5.2 Our Wounds: Keeping the Tsunami Trauma Open
}

\author{
Disaster from the city of tears \\ Hundreds of thousands of souls went before us \\ The wounds burn a sense of belonging \\ Coils of wounds create a lamp
}

My brother who went did not only leave a name My brother who went left behind a million meanings

My brother who went to wake up the world

In order to understand the deep meaning of life

Show us that we are all brothers

Their wounds cut us all

Show us, we will show

The suffering we have suffered

My brother left a task for us

A teardrop makes a gem

The magnitude of the disaster is greater than the wisdom

We who go smiling to heaven will make it happen

My brother who went did not only leave memories

My brother who went left behind millions of meanings

My brother who went to wake up the world

To understand the meaning of life

'Our wounds' ('Luka kita') ${ }^{6}$ by Marjinal

As the eyes and the helping hands of 'the World"7 contributed to the emergence of Aceh from a relatively unknown, conflict-closed Indonesian province ${ }^{8}$ to a disaster and state-building, aid-policy laboratory, so songs such as 'Our wounds', 
by the Jakarta-based punk band Marjinal, actively participate in expressing punk solidarity in the face of Aceh's losses and the necessity to act: 'my brother left a task for us. This song, after being released initially in 2005, became hugely popular across Indonesia, to be repeated by buskers with ukuleles in the streets of Indonesian cities, including Banda Aceh itself.

Every day, between five and 10 punks, mostly males in their 20s, would gather in Banda Aceh at the Tsunami Museum ${ }^{9}$ after just a few hours of sleep in the streets, parks and abandoned houses. The raised ground floor of the museum provided shelter both from the hot sun and from the rain, and thus was ideal for hanging around: leaning on the pillars, smoking, watching cars go by, checking out motorcyclists and museum visitors, flirting with shy, giggling, teenage girls, watching and mocking the Shari'a Police patrols passing by. Other hanging-around activities at the museum included making DIY T-shirts, patches, bracelets, earrings and necklaces, polishing their boots, regulating the punk street political economy by punishing those stealing money, sharing and debating punk and anarchist ideology, squatting, sleeping, daydreaming, playing guitar and self-made drums - described as bosan (boring) in connection with the anticipation of eventfulness and the destruction of routine.

Idleness or lethargy was occasionally boosted with mixed substance use, which seemed to be, at least for some of the punks, a way to regulate affects: slowing and toning down fears and anxiety and replacing them with utopian euphoria and hallucinations, out-of-body experience and detachment, feelings of losing oneself and being united with the surrounding environment in a boundless and bodiless consciousness, as it was described to me. However, moments of euphoria and clarity were followed by days of confusion and agony, potentially the result of a bad 'mixture' or withdrawal symptoms. ${ }^{10}$ Confusion and agony could be accompanied by the loss of items like the needle and thread used to stitch patches, by unrealised plans such as hiring a car and going to the beach or problems that seemed trivial multiplying and causing enormous stress. Thus, what I was observing as boredom was potentially also partially a result of trying to deal with it: 'It [drugs] is just such an easy way to cope with boredom (bosan)', as one of them told me.

Without wanting to romanticise or demonise such experiences, let alone support the common claim that all punks in Aceh use drugs, I argue that being bored and being high construct alternative ways of occupying the city, and provide a means to deconstruct the self and the normative temporality that results from embodied governmental practices, such as being beaten up or arrested and detained for several days. In fact, these acts and experiences, I would argue, can be seen as resistance to post-disaster governmentality and a simultaneous reconstruction of utopian punkness, an escape from boredom, anxiety and negative thoughts into the punk aesthetic creativity of writing lyrics and drawing.

Yet, the fact that most of the 'being bored' time was spent at the Tsunami Museum can also be read to signify other things. As one of the punks explained to me, hanging around at the museum was their way of becoming visible. Being 
one of the major touristic sites of the city (see the discussion in Chapter 2), tourists from different parts of Aceh, Indonesia, the Malay Archipelago and the rest of the world cannot miss the punks hanging around in the unused cafe section, just next to the museum's prayer room.

This same visibility, however, also made the punks vulnerable to the violence of museum security staff and military police. In fact, hanging around at the museum was a result of having been evicted from the nearby recreation park owned by the military. Some of the punks slept under the counter of the unused cafeteria space; however, they were warned not to use the premises outside the museum's opening hours. After a violent attack by plain clothes military police in 2013, punks were temporarily forbidden to enter the museum premises. A few weeks later, however, once the situation had cooled down, they made their return. Forbidden or otherwise risky locations were commonly referred to as panas (hot), signalling a potential confrontation with the state apparatus, be it the military, the regular police, or the civil and Sharia Police officers. This meant periodic nomadism from one locale to another. Yet, during the 20132016 period when I conducted my research with the Banda Acehnese punks, daily routines were centred on the museum and an alley in Peunayong, the city's Chinatown.

Punks in Banda Aceh had gained more urban visibility after the tsunami and the peace process, as occupying streets at night-time during the conflict was risky. However, it does not mean that this earlier invisibility equalled 'non-existence'. In contrast to claims made locally that the punk ideology had arrived as one of the many 'Western influences' in post-tsunami Aceh, due to aid and foreign influence, the vibrant punk scene in Aceh has existed at least since the early 1990s. It shares an ideological and collective history with the punk and anarchist communities within the rest of the Indonesian archipelago - opposition to the authoritarian regime of President Suharto, militarism, neoliberalist economic reforms and corruption - but it is also a reflection of Aceh's specific situation, that is, the armed conflict and political disputes (Wallach 2008; Aiyub 2011; Idria 2013, 194; Donaghey 2017).

Being openly against militarism in Aceh (both the army and ex-combatants of the independence movement), in addition to hanging around in highly militarised locations in the city, poses a visible contrast to dominant forms of masculinity in the post-conflict context of Aceh (Bolong and Jauhola 2017). The punks' inaction and boredom actively mediated and negotiated their masculinities vis-à-vis the dominant forms of militarised hyper-masculinity in post-conflict Aceh and, more widely, bapak masculinity - whereby senior men of a family have authority over everyone else and might thereby subject younger men and females to forms of control and subordination (Boellstorff 2004; Nilan 2009, 333). Being a punk also challenges the family orientation of Indonesian and, specifically, Acehnese society (Beazley 2003) and the collective norm of malu (shame or embarrassment) (Boellstorff 2004; Lindquist 2004). Furthermore, punkness seemed to provide a space for prolonged 'waithood' 
(Singerman 2007, quoted in Onodera 2015, 189): the period before the expected marriage and family life, and one of resisting demands to know and act', become productive and contribute to family welfare, by drifting and being bored. Yet, what seemed at first to be a coherent single local community was in fact one in constant change and movement: sub-groups emerged, individuals were evicted, some left and joined other punk groups or found work elsewhere in Aceh, North Sumatra, or Malaysia. Punks were in constant movement.

\subsection{Rhizomatic Homes across the Indonesian Archipelago}

My past life in entertainment trapped, confused to please others rolled up tight, scratched stains forced to appear as a winner in a cheap film, cheap role, murky role

thunderous applause, cheers in my soul as if the audience would finally understand me unquenchable fiery red like a wounded bull pain, gore hard and bright

sad song that used to accompany me not strong anymore to merge into the pulse vomiting all the sewage on my chest my tongue already numb

Mama, I'm coming home, please heal my injuries

I miss the table, to have tea with you

'Cheap film' ('Film murahan') by ROMI \& The JAHATs

'Cheap film', a famous song by the band ROMI \& The JAHATs, when sung by the Banda Acehnese punks when busking, could be seen as a self-ironical reflection of the global fame and celebrity status initially gained by the Banda Acehnese punks after the large-scale and media-hyped arrests in December 2011. The song resonates with the nomadic street life of the punks, both those from Banda Aceh and temporary visitors: 'mama, I'm coming home, please heal my injuries. I miss the table, to have tea with you'.

Yet, the relationships with their 'mamas', or parents and family, varied drastically. Although dominated by young-adult punks, some who had lost their parents and siblings in the tsunami, the community also consisted of under-aged youth on the run, whose families were trying to locate them as they were worried they had not been home for a long time. ${ }^{11}$ Worried adults also included at 
least one state legal aid officer seeking her client in an effort to enforce the institutionalisation of a convicted under-aged adolescent (for details, see the next section). One member, an emerging leader within the community, deployed a punk identity to combat his late violent father and flee a militarised home (see the discussion in Chapter 4), but ended up embodying the violence of the city himself after being beaten up by the military, police and prison guards during detention. There was another who, after several violent arrests and detention, severe drug abuse and the loss of both parents, joined an Islamist group, Hizbut Tahrir Indonesia (HTI), and their ashram, thereby gaining a new family, later returning to the streets and his former punk community for da'wa, Islamic preaching. In October 2014, the community mourned the death of one of their younger brothers, Romi Borjong (Medan slang which translates as 'Romi the ghost'), who died after being run over by a car in Palembang in South Sumatra.

\subsection{Justice - Studying Up the Rule of Law}

In this section, I reconstruct an arrest, a detention and a trial of two punks in the aftermath of an event named and framed by a local newspaper, Serambi Indonesia, as the 'Rex incident', in which punks were accused of having attacked a customer at an open-air food stall complex, locally known as 'Rex', on their evening busking walk through the city centre. By focusing on the Rex incident, however, this section re-shifts the focus from the global spectacle of December 2011 to the more mundane gendered experience of structural and physical violence (see also Jauhola 2015b). It casts light on the politics of controlling punk masculinities that leaves intact the upper levels of a hyper-masculinist and violent political economy, and control of urban space by the preman gangs in post-conflict Aceh (see Chapter 4 for discussion of the role of premans in urban Banda Aceh, and Indonesia more broadly). In the words of Yudi Bolong: ${ }^{12}$ 'Law is only a show for the upper class, whilst for the ordinary people, it is terrifying.' Further, the section narrates the obstacles, resourcefulness and ways of coping after the height of the massive global punk solidarity campaign had passed. The analysis also locates a trend in media reporting and global solidarity that reproduces the constructed dispute between Sharia and the right to be punk. I call this punk ethnography 'studying up the rule of law', as I argue that the continuous punk presence in the city, and the strategic narration and visual documentation of punk experiences, is a means to study and narrate political economy and relations of power (Jauhola and Bolong 2014). The analysis draws from research data collected over nine months from September 2013 to May 2014. During these months, I followed the arrest, detention, court and legal aid sessions of two punks - Yudi Bolong and Muhammad ${ }^{13}$ - initially on social media, and later in Banda Aceh in various locations such as the prison, court, streets and homes with the key people involved (girlfriends, family members, punk community, legal aid). 


\subsubsection{Chronology of the Rex Incident}

The first difficulty in constructing the chronology of events of the Rex incident was deciding where to start. Perhaps the phone call I received from Yudi's girlfriend Bunny ${ }^{14}$ giving me a detailed account of what had happened, seven days after the incident? Or a review of local newspaper articles published a few days after the incident? Maybe an account of the arrival of drug police in civilian clothes several days earlier at the punk alley seeking a marijuana haul? Or the official court documentation - the police investigation report used by the prosecutor, the witness statements by the accused, witness testimonies that were called by the prosecutor and defender, the cross-examination process, the final statement by the judge? Or should it be the feelings of confusion, paranoia, fear, anger and frustration that came with participating in the hearings and spending time with the defendants and their families and friends? In fact, any account should illustrate the coexistence of multiple versions of 'what happened' and the contradictions they entailed.

In the space available, I construct one possible chronology of events from my field notes and conversations, with the addition of media and court materials. Establishing the chronology of events with any exactitude is impossible, as notes and memories are always sporadic and incomplete. It should also be noted that I organised these materials after the occurrence of events, meaning that, at the time, those involved, including myself, were often not cognizant of the overall picture. It is common that male punks let their girlfriends access their social media profiles and, therefore, when the author is known to be someone other than the holder of the profile, this is mentioned. Otherwise the chats and statuses are quoted as they appeared in the researcher's own profile. ${ }^{15}$

A few months before the incident, I had been in touch with the punks, wanting to share the result of my first presentation at my university. I was told that there were plans to organise some underground gigs, with Yudi adding that he was worried that punk arrests would start again, as there had been some during Ramadan. Yudi made contact few weeks later, saying there had been new head shavings ${ }^{16}$ and a scuffle with the civil service and Sharia Police (Satpol PP and WH) over an accused violation of Shari'a regulations on immorality. As there was no proof of any violation of law, the authorities had released the punks after the interference of a legal aid NGO. In October, Yudi once more confirmed that the streets were becoming unfriendly towards them and local restaurants were banning busking in their premises. Some German punks had come to visit on their way to a beach holiday and the gig arrangements for late October were going well.

\section{Mid-November 2013 (from retrospective information gathered during fieldwork in Banda Aceh)}

Civilian drug police hit the punk alley, having been tipped off about a ganja haul. Police look for the drugs, find none and are reported to have used physical force. Nine punks are arrested. ${ }^{17}$ 


\section{Thursday 21 November: On social media}

Yudi (status): ('feeling special') Banda Aceh is heating up and getting extremely hot ... hehehehhehehehhehehehehheh

Yudi (chat): Po and Muhammad have been arrested by the police. I just came from the legal aid NGO office and from the city cop shop but the aggro is still going on. They don't treat people humanely. I also have a recording of them dragging people into the car. They tried to snatch the camera, but I gave it to Bunny. That's why the recording's so short. We had no drugs on us. We were clean. Please contact the National Commission on Human Rights in Jakarta. To get evidence of what happened. Please contact Bunny, my mobile got lost during the incident. Please, I'm begging you, this is really serious. But it may get even more serious. Marjaana to Bunny (chat): $\mathrm{Hi}$, I just heard about the punk arrests from Yudi. Bunny: Yes. I was there too and managed to get this video.

Marjaana: Oh, plainclothes cops?

Bunny: Yep. Friends got beaten up. It was horrifying. Nine arrested, all guys. Marjaana: Oh, so the word I get from women activists that females were also arrested, isn't true.

Bunny: We don't know what to do. We've already reported this to the cops, but they don't want to protect us. Because the guys who beat up on us were cops too.

Marjaana: Plainclothes. Sounds like an undercover drug operation to me.

Bunny: Exactly. They were looking for $\mathrm{X},{ }^{18}$ but instead we became the targets. They had no proof of anything, yet they used force.

Marjaana: How can I help you?

Bunny: If you have friends in foreign media who support punks in Aceh, please let them know. Who knows, maybe they want to help.

Marjaana: Okay. I will post updates on Facebook. I've a few friends who are journalists, and also some human rights activists in Indonesia.

Bunny: We're really messed up about this. No one wants to help us.

Marjaana: This sounds like it's part of the city's wider campaign against drugs, exactly in line with what the mayor has been saying about youth and drugs. I think they are specifically targeting street use.

At this point, I began to try to contact my human rights and law connections both in Jakarta and Banda Aceh. I kept Yudi and Bunny in the loop and circulated Bunny's mobile number, and she would become a central person in coordinating the search for help and engaging in advocacy internationally, especially a few days later, when Yudi was also arrested.

\section{Friday 22 November}

Two articles and three photos were published about the Rex incident on Friday. The first, published online by Serambi Indonesia at 09:27, was titled 'I did not 
know my child had become punk' (Anon. 2013b), where the mother of one punk is reported as having said, with tears in her eyes, 'During this time I did all the cleaning, ironing, and generally spoiled him, until very recently, when he had become older. I still make his bed. Turns out this is what I get back. I did it for him so that he can study.'

\section{Serambi Indonesia, 22 November 2013: Punks attack a Rex customer}

- A Montasik resident with bloody head wound

- A table upturned and victim beaten

The culinary centre of Banda Aceh was suddenly disturbed on Thursday midnight (21/11) when dozens of punks made a massive attack on the location. A gang of these punks mobbed a young man from Montasik, Aceh Besar, called Reza (32), resulting in a serious head wound.

... The beating started when a punk, with the initials Po (12 years old), asked for 10,000 Rp. from Reza's friend Faisal (31). Having been refused, Po moved towards Reza, which made him scared, shocked and angry, obliging him to pay ... 'Reza did not give him money. Maybe that was the only mistake he made. In fact, according to us the punk kids have already gone too far. It's not just my feeling, other customers have also felt quite disturbed', said Faisal, whom Serambi [Indonesia] met at the city police station in Banda Aceh yesterday.

Faisal, Reza's friend, said that he had told Po to work if he wanted to earn money. In response, Po rudely upturned tables, scattering plates and cups. 'It was becoming a heated situation, especially when punk friends arrived from close by ... they beat up Reza. It was an uncontrollable situation. In fact, no one could help when they saw the numbers, up to 20 punks', Faisal said.

'As a result of the beatings, my brother suffered lacerations to his head and his diagnosis is that he has a burst artery, or bleeding in his brain. And also cuts on his eyelids', M. Hatta, Reza's younger brother, reported.

Anon. 2013a

Serambi Indonesia included three photographs on their online portal of the arrested punks inside the city police station. The faces of the punks were blurred, but anyone who knows the punk scene would recognise them. The photographs also provided details of crime-scene 'evidence': a broken ukulele and an emptied Teh botol (popular Indonesian drink) filled with colourless liquid, suggesting illegal alcohol consumption. The authenticity of the ukulele in particular was contested in court: none of the punks recognised it as belonging to them. 
Another local online media source used the Serambi Indonesia text, republishing it two days after the incident with the altered title 'Refused 10,000 Rp, punk kid goes berserk in Peunayong. Meanwhile, Yudi had already warned the punk community on social media about the biased reporting by the local newspapers and was, together with his girlfriend Bunny, sending alternative accounts of events across the globe. A short synopsis of some of this communication follows.

\section{Friday 22 November (continued): On social media}

Marjaana to Bunny (chat): Are there any updates? Yudi was very scared yesterday, I hope there are no new complications because I have not seen him online today. Are Po and Muhammad still detained? I read the Serambi article today, but do not know what version of the truth it was, Serambi's version, or someone else's.

There was no response. I wrote on my Facebook wall: 'What a day, social media making stuff more intense than one could have guessed few years back; making preparations to return to beloved Kuta Raja, ${ }^{19}$ one day. Now it's time for grey day in a grey city.'

Yudi (status): Facts are changed and distorted, right.

Yudi (status): Aceh is a field of poverty.

Yudi (status): This is a photo from a hoax arrest by people who identified themselves as city drug police on Tuesday at 6.15 pm in Rex, Peunayong, Banda Aceh.

Yudi (status attached to a photo with a banner 'The government of Aceh has failed to improve the welfare of the people'): This is the reality of a state that claims to be wealthy.

Yudi (status): Up the punk and stay together.

Yudi (status with photo): This is one of the victims, our friend, who was detained by the police, who had indeed been in the vicinity of the incident but had done nothing wrong; he was freed by the police after being battered. [The subject's eyes are swollen.]

Yudi (status): ... Please do not spread the Serambi article that is flipping the facts to other friends. It is clear that we did nothing wrong, we're victims of libel.

\section{Saturday 23 November}

Marjaana to Bunny (chat): Any news about the friends?

Bunny: A Montasik guy was a victim of violence. Yudi is afraid there will be a mob of angry people arriving in Banda Aceh for revenge. Yes, that's the 
Serambi version. But it's not what really happened. Po and Muhammad are still detained. Marjaana, can you help us? Or is there someone I could contact? I can give them updates directly.

Marjaana: Yes, I will give you my contacts to human rights lawyers as in case there is a court process, they'll need legal aid. Do you have access to the police station? By law, if they are detained for over 2x24 hours, they have the right to legal counsel. I am reading the law on criminal procedure, article 18(1-3) and article 19(1-2). This means that the police must present a formal letter stating the reason for detention.

No response that day.

Michael Rothstein, the punk activist in the United States who had initiated the punk song collection Aceh calling (Punk Aid 2012) as part of Punk Aid group activities, posted Yudi's update on his profile. The text was written by Yudi and translated into English using Google Translate, a common tool used by Acehnese punks to communicate with the outside world - which, besides being a communication tool, is also a source of misunderstandings and confusion as spoken/slang Indonesian translates badly. The originally posted text, with no grammar corrections, read as follows:

\section{Update from Banda Aceh punk Yudi Bolong}

Within 2 days, violence and physical abuse happening to us the punk on Tuesday at 18:15 AM in around the area of culinary rex, penayoung banda aceh yan performed by a group not known that he who sat admitted drug Banda Aceh police, for no reason clear.

and Wednesday night around pukul 23:50 raw hamtam happen again with people not in the know with a bit grim face he shows bayonet (a sharp weapon) to my friend and pushed him, the spontannitas / reflex friends see friends who just holds the hand that holds the bayonet (sharp weapon) and start mass judged.

after that the police acted in a way worthy of his propensional not a police, they arrested another friend of a friend who does not know anything about the incident, and I was also at the scene was not even me that in the search by the police now

I was restless, anxious, fearful, felt very intimidated by their behaviour why we are always on the isolate, we do not interfere and do not commit crimes, we work with what we can clearly would never disturb / harm the future of those around, but why are we always in bother after we act even in the corner is so humanize the way people around the human human [sic] for anyone who still has a heart and a conscience could possibly understand my words mean and what to do 
Thank you

UP THE PUNK

OI ... OII OII ...

Yudi (status): But when you think of the style of the idiot who thinks like a beast ... I will

Be sharper and exceed rumbling thunder to burn your soul ... friend ... ???//////

Bunny (status): I continue to pray for you, all my friends who are currently behind bars as a result of an incident that is not real. Continue to be patient. Perhaps, right now, we are blamed. But later, we will prove that we were right.

Friends commenting: What is the problem?

Bunny: Kids in Banda Aceh are detained by the police. Because a person was beaten up at Rex in Peunayong. But the customer is wrong about it. Because it was him who used a bayonet to attack people.

\section{Sunday 24 November}

Bunny to Marjaana (chat): Thanks. Muhammad's family has not received any letters. This is my mobile number. Please give me yours so that I can be in touch.

Bunny to Yudi (status): Keep smile =) [Smiling emoji] hehehe

An anonymous punk (status): The prosecutor is unjust. To have money always beats not having it.

The official release letter dated April 2014 states that Yudi was arrested on 27 November. However, in social media, news about his detention circulated one day earlier and a legal aid NGO had begun preparations to defend his case even earlier.

\section{Monday 25 November}

Marjaana to Bunny (chat): I heard that Po and Muhammad are freed, is it true?

Bunny: They are still detained. I just got back from the cop shop. But they wouldn't let me in. They said they can't be visited today.

Marjaana: Ok. I received this from a legal aid NGO: 'Hi Marjaana, a legal aid NGO is handling Yudi's case. The Rex incident is still under investigation. Muhammad and Po have been released from the police station.'

Bunny: I think we need a lawyer. People are not responding to my requests 


\section{Tuesday 26 November}

PUNK AID (status): FREE Yudi Belong! Yudi has been detained in Banda Aceh for being a punk rocker. Show your support for Yudi! Here is a picture of him with his copy of PUNK AID: ACEH CALLING by Punk Aid.

Bunny (status): For me this ordeal is really hard. My darling inside there $=($ [sad emoji]

Friend's comment: Please be patient Bunny $=($

Bunny: Please pray that Yudi will be released.

Friends' comments:

- Why?

- I will pray I can join him.

- Amin.

- Where?

- Where is he? At the police station? I will visit him, I am his older brother. - Cool.

On that day, Michael Rothstein provided another update on his public profile:

Banda Aceh update: bad news. It looks like our friend Yudi Bolong who has been providing updates from Banda Aceh has been detained according to his girlfriend.

'Hi michael ... yudi now been detained at the police station. I am very confused with this problem. I'm girlfriend yudi.'

Please keep Yudi and all the other Banda Aceh punks in your thoughts and let me know how we can sell enough punk aid comps to put some bands on a plane to go out there put on a show for these people.

After this, there were no further public updates on Acehnese punks from Punk Aid and Michael Rothstein on Facebook. Mistrust between Punk Aid and Acehnese punks developed around the time of the trials when Acehnese punks tried to inform the US end how sales revenues were being used locally in Aceh; originally the profits of the Punk Aid 2012 Aceh calling compilation were meant to go to Movement Records in Jakarta. When released, Yudi tried, with the help of Google translator, his girlfriend and myself, to communicate back to Punk Aid and Michael Rothstein what the court case had been about and the situation with the money, but it seems that as of 2016 relations have remained distant.

Most discussions of the case and legal aid meetings were held in private. In the following, I present a few examples of these 'hidden tapes' from the pre-trial period. 


\section{Thursday 28 November}

When Bunny called me a week after the Rex incident, I could hear from her voice she was panicking. All I could do was calm her down, promise that I would provide phone numbers of lawyers, women's activists and people known to have a 'good heart', and that I would continue chatting with her in case I could help. Yudi had visited the police station to report that the police had assaulted him, but, instead of filing his complaint, they detained him because the owner of a nearby internet cafe, who had become a part of the situation, claimed that Yudi had hit him. Yudi had given a statement that formally allowed a legal aid NGO to assist him.

On the same day, I heard that Yudi had been beaten up at the police station. Around this time, I began to question my loyalty and interests. What happens if no one helps them? What might happen to those, like myself, who do help them? What about all those other cases where corrupt police get away with crimes against people who have no connections to the outside world or legal assistance? Who am I to choose whom to help, and how will helping this once change the big picture of power misuse and innocent people paying the price? What if the punks really were wasted and started the fight?

On that day, I also got an update that a locally prominent journalist had decided not to write on the case in the English language media (The Jakarta Post) because it seemed to be a 'pure criminal case'.

\section{Friday 29 November}

Bunny (chat): This is a photo I took yesterday. He was beaten up by the police.

Marjaana: Have you had any success in gaining (legal) help?

No response. I hear from an Indonesian friend helping Bunny from a distance that the police have apologised for hitting Yudi. There is news that the NGO might not have enough staff to follow up this case.

\section{Saturday 30 November}

As a part of 16 days of international activism combating violence against women, the Acehnese women's organisation Aceh Women's Peace Foundation (AWPF) releases a campaign video of punks singing the Marjinal song 'Marsinah, ${ }^{20}$ with Yudi orating 'Punks reject all violence against women, whether moral, physical, or any other kind. Because we all are the same, do not raise yourself above God. Stop violence against women to support peace in Aceh' (AWPF 2013).

\section{Monday 1 December}

Bunny (chat): I cannot visit the police for another week as I have work to do. Until it finishes mid-December. 


\section{Tuesday 10 December}

Marjaana (chat): Any news? I've not heard any updates for a long time. Bunny: Increasingly bad. Yudi has failed in his complaint against the police who beat him up.

\section{Monday 16 December}

Marjaana (chat): What's up?

Bunny: Good news. Yesterday Yudi reported the assault. They are trying to settle it without a trial. Yudi wants to report the police. And police want to report Yudi. And he is still detained.

Because the owner of the internet cafe does not want to settle the case, or only if he is paid. Yudi has to decide between going to prison and paying him money.

Marjaana: What about Po and Muhammed?

Bunny: No news yet. They are both detained, maybe for eight months. The people involved do not want to settle.

Marjaana: How old is Po? Not yet 18 ? Because his case will be different then. I mean he is still child.

\section{A few days later}

Bunny (chat): Slight improvement in Yudi's case. This time it was really difficult. Yudi became ill in prison and I don't work anymore. So I have not been able to see him for long time. Because every time I visit him, I have to give him money. And he then gives it to the guards.

Chat records end here; the rest were lost six months later when Bunny deleted her account after she had successfully got into the police academy in June 2014, just a month after Yudi was released. Bunny has disconnected herself from the punk community.

Before that, Bunny continued supporting the two remaining punks in detention. Po, who was the only punk identified in the original newspaper article, was trialled separately and with the help of the state's legal aid office as an underage convict. He was charged with violence, to receive a six-month sentence, was sentenced for three months and was released having completed the sentence at the time of the verdict. The legal aid official tried to return him to his parents and enroll him in a residential Islamic boarding school to finish his formal schooling, but he went missing soon after his release. No one knew where he was until he started posting pictures again from Medan and beyond. By the end of January, after two months of detention, there was still 
no sign of Yudi and Muhammad's trial. Bunny repeatedly mentioned that they were harassed in the prison, by guards and other inmates, and that money and exchange items (cigarettes, rings and gems) were used to improve their condition. Bunny continued to update me on her attempts to find legal aid; it seemed that the paperwork required for Yudi's legal aid, such as evidence of low economic status, was elusive as his family lived in another district. Finally, the NGO providing legal aid did so without the documentation. Law 16/2011 on Legal Aid guarantees that organisations providing legal aid services can get government refunding if the recipient of the legal aid is able to provide a poverty statement letter. This requires gaining a recommendation letter from the neighbourhood head, community head, village office and the sub-district office (Irwan and Hearn 2016, 15).

\subsubsection{The Trial}

The two court trials took place from February to April 2014, and the sessions for Yudi and Muhammad were usually held on the same day, one after another. They would arrive from the prison in a big bus with others on trial the same day and were held in a special cell that faced a bench where family members and friends would wait for the session. Although the schedule of each day was announced on a TV screen, usually the accused had no confirmation of the exact timing of their session before the guards called their names and opened the cell door. Sometimes this waiting took hours. Judges were ready, but the prosecutor had not arrived. The stress was mounting. Would the legal aid arrive in time? What if the session was cancelled for another day?

While the prosecutor kept building the two cases using strong language about the unfit appearance of punks (clothes, tattoos, hair), thus aligning with the general social-misfit attitude towards the punks, the legal aid observed that the attitude of the judges, initially similar, had changed over the sessions towards being more open (udah buka). In general, the legal aid encouraged outsiders, in particular family members, to attend the sessions to increase the likelihood that the sessions would follow formal procedures. My arrival in the courtroom in early March was noted by the panel of judges, and the main judge acknowledged it formally, saying that as there is an 'international observer' present, the court should provide a fair trial. I used to sit in the courtroom together with the family members, thus clearly marking myself as a part of the party of the accused.

The prosecutor's letter of indictment demanded imprisonment for seven years for Muhammad, accusing him of causing serious physical injuries to 'Reza'. Despite such a heavy penalty, the victim did not appear in the court, nor did he identify Muhammad as the main suspect. Furthermore, three of the prosecutor's witnesses denied having seen Muhammad at the crime scene, contradicting the police report that was written during the investigation period right after 
the arrest had taken place. The main judge was furious about the prosecutor's handling of the case, and the failed prosecutor-police collaboration. Defence witnesses gave testimonies that Muhammad was in fact somewhere else at the time of the Rex incident. Yet, when cross-examined, most of them were unable to give convincing accounts of the events that had taken place three or four months earlier. This is not particularly surprising in punk temporality, where days, weeks and even months do not have such a clear distinction, but, rather, are repetitive (on repetitive daily schedules, see also Idria 2015; Jauhola 2015a,b).

Finally, Muhammad's legal representative made an objection (eksepsi), noting: 'We feel it is necessary to convey this exception in the interest of law and justice as well as a guaranteed protection of human rights' (18 February 2014). The objection started with a reference to the Indonesian Criminal Code Procedure (KUHAP) that guarantees equality of Indonesian citizens before the law. It raised concern over the police investigation and the report that was the basis for the charges, including procedural errors, such as applying the wrong imprisonment term for the charge (seven years instead of five to six) and neither notifying the detained of his right to legal counsel nor appointing one. The objection also focused on the need to follow 'due process of law' in police investigations, specifically mentioning the restrained use of brutality to coerce confession, psychological intimidation, the right to remain silent and the right to the presence of an attorney. On 17 April, the judge's verdict stated there had been no evidence of crime and Muhammad was to be released. The prosecutor appealed to the high court in May, but the high court rejected the appeal in December 2014. Curiously, the high court verdict was formally documented only in March 2016, 15 months later. The legal aid representative suspected that losing a case like this would look bad for the prosecutor's future career, especially as it pointed towards severe procedural mistakes. Muhammad's family was upset. Supporting their son who had been detained in total for five months had been expensive. In the end, they received no compensation, although their legal aid representative tried to retrieve the money.

Yudi's case focused on the accusation by the internet cafe owner that Yudi had punched him in front of the cafe (on the day of the drug search). For Yudi, the prosecutor's demand was two-and-a-half years of imprisonment. During the trial, the chronology of events was reconstructed and the judges' verdict was that, although Yudi had punched the owner, it was a reflex reaction to being pushed and punched by the owner in the first instance. He received a sentence of five months and, as he had been detained for four months by the time of the verdict, he was given a release date for the end of April 2014. The police violence in the street and in detention was not processed, as it had been in Muhammad's case. Having been returned to the prison after the verdict, Yudi refused to pay the prison guards $500,000 \mathrm{Rp}$, which would have allowed him to walk out on the day of the verdict. 


\subsubsection{Written by Yudi Bolong at Tsunami Museum}

Banda Aceh, 26 May 2014 ${ }^{21}$

\section{Part I}

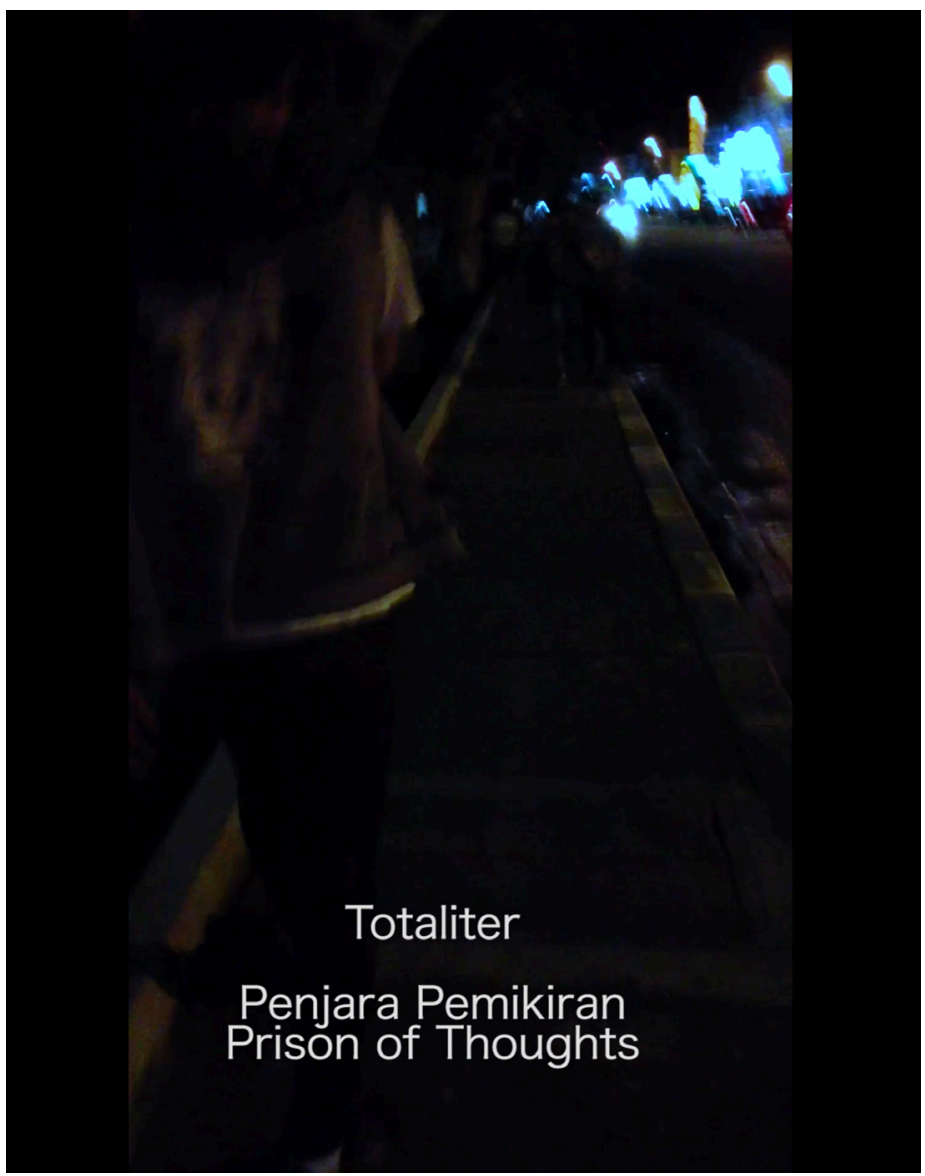

Video 12: Totaliter: penjara pemikiran/prison of thoughts (02:12). Source: Scraps of Hope.

To watch this video, scan the QR code with your mobile device or visit DOI: https://doi.org/10.33134/pro-et-contra-1-video-12

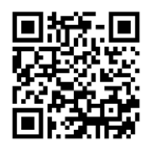

Materialistic slaves

Fixed ideology and idealism

So be prepared! 


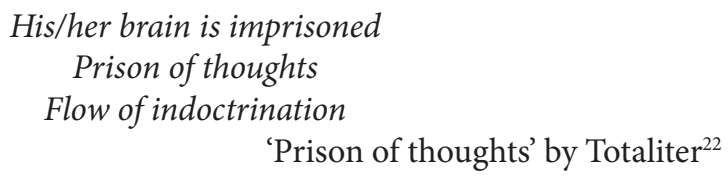

The inspiration for this song came from a Javanese band called Bandit Chaos. ${ }^{23}$ The song describes a situation in Aceh where many people imprison their thoughts. Thoughts that are the result of indoctrination by the rulers. Rulers who wish to lock up people's thoughts so they become hostile towards difference.

The impact of this illiberal thinking gives a rise to prolonged conflict in which a system is created that dogmatises people's lives. Thus, to the imprisoned, this way of thinking still exists.

\author{
MY LAND \\ My land is no longer beautiful \\ Because it is exposed to oppression \\ Now, I have to resist it \\ Resist the cruel ruling system \\ We resist all your systems \\ We resist your arrogance \\ We resist all your stupidity \\ Rulers are fuckers \\ Always spreading promises \\ But there was never any evidence \\ Ordinary people are under illusions
}

This is a song about the revelation of our feelings in the process of 'being made stupid' that happens in our country. A country that is proud of its orthodox thinking.

The impact of their action is: those who are strong control, those who are weak are corrupted, those who are rich become richer, those who are poor become poorer, those who are clever deceive, those who are ignorant are cultured.

That is indeed the reality in this ragged and scruffy country.

Duped system becomes the weapon for itself

And the more stabbing of their conscience

So, do we have to remain silent when stupidity stabs our conscience?

\title{
Part II
}

Law is only a show for the upper class, whilst for the ordinary people, it is terrifying Why do I think like that? Because it is all happening because of money. 
Where money becomes a necessity for the upper class, All of it, in fact, is capable of challenging the Godly powers

Where justice can be bought and engineered by those who regulate it.

Thus, because of that I resist authoritarian system that exists in this country. Because their policies are good for this small group of people and intimately we come to the conclusion that ordinary people are talismans of their policies

And what is crystal clearly observed here is that justice can be bought with money.

This is a text I wrote when I was still detained in the prison of Kajhu in Banda Aceh as an inmate and had to go through five months of imprisonment.

A.C.A.B

Fuck the government

They are dictators

Fuck the police

We are a moving resistance

\author{
A.C.A.B \\ All cops are bastard \\ Kill all the system government
}

I wrote these lyrics when I was imprisoned. This song is an expression of my feelings towards the government and police in this country that always wish to conquer, never accept blame.

\title{
Part III
}

Take a look at that water buffalo

That is pulled and pierced from its nose

And it is forced to obey

And take a look at those who graduate

Who are legitimated to become intellectuals

(Only to get a formality

please explain, give an explanation

You are not allowed to do like this, you are not allowed to do like that

You have to do like this, you have to do like that)

\author{
And he/she also is forced to obey \\ And forced to remain silent \\ To obtain legality \\ And only formality
}




\section{Please explain \\ And clarify}

'Mahakebo' by Marjinal24

The above sentences prove that the education in Indonesia is only a system of stupidity/ignorance that is real, where education can be enjoyed by a few rich ones. Meanwhile, for the ordinary people, education becomes a burden for their lives. The one that speaks is money.

The research that exists in Aceh at the moment about the lives of punks is written from a perspective that does not appreciate our lives as punks. Information about punks is not gathered directly from punks. They publish false information of the punks to the academics and for the general public. This becomes a serious problem for the punk community. 25

\section{Part IV}

Local media publishes false information about the punks. Stories and facts are reverted and twisted according to which it is only the punk community that is always to blame.

Finally: What is clear is this: to become a punk in Aceh means heavy challenges.

\subsubsection{Marjaana's Reflection on Gendered Everydays of Ethnography}

During the punk ethnography, my role aligned with the gendered roles of the girlfriends and Muhammed's female family members: maintenance of social relations outside the prison, visiting the prison and the court to provide care and financial resources, and using the women activist network to gain legal aid for the accused. These roles resonate with the continuum of the more mundane heteronormative gender order of the punk community in Banda Aceh (Jauhola 2015b).

Having arrived in Banda Aceh in March 2014, I visited the prison where Yudi and Muhammed were detained. It was the same day that the former rector of the University of Syiah Kuala, Darni M. Daud, arrived in that very prison after he had been sentenced to two years for misusing $125,000 €$ meant for scholarships for poor/unprivileged students in 2009-2010. Over the months that followed, I witnessed the former rector's special treatment and visiting rights in a separate VIP section separating him from the other inmates. In the prison cantina, Yudi and Muhammed recounted physical mistreatment by other inmates and prison guards, and the political economy of the prison and the legal system, but also the embeddedness of the education system within those structures - all of which Yudi reflects upon in his writing above. 
The time spent at the court illustrated how randomly the daily schedules were structured; it was up to the main judges and the prosecutor's office whether trials were cancelled or postponed, causing an increasing amount of anxiety for the female family members. Delays and cancellations also pointed to another gendered structure - female judges and prosecutors had difficulties in combining work and family life and thus left the court early to pick up their children from day care. The cantina at the back of the courtyard is also known to be the location where bribe payments take place. There was no evidence of this, although I recall a few occasions when the male leading judge of the punk case socialised extensively with the family after the court proceedings.

Listening to the recordings of the court sessions, and reading my daily notes, a predominant feeling of losing touch with reality and the truth, and the quest for truth, grew in me during those months. I followed the female legal aid representatives who took turns in representing the accused. They identified where due process and procedures were not followed, collected evidence, searched and prepared witnesses, and translated legal jargon and procedures to the accused and their families, sometimes successfully, and sometimes less so. They indicated that the police could be charged for malpractice during the investigation and detention and that they failed to charge the right people for the Rex incident. Over these months, the unmentioned ganja haul and the attempt to charge the punks with drug offences kept looming over the case and caused feelings of insecurity and paranoia for me. The fact that 'Reza' was ex-military police was never brought up in the court discussion or public media. Formally, both court cases point the finger at police misuse of power and the normalised use of physical violence in arrest and detention - but normalise forms of extortion of money in detention and the trial, and render the motivations for the mid-November drug arrest invisible. During my stay in Aceh, I heard a number of theories that focused on people being paid to tip off the drug police, and the police who were investigating the Rex incident.

Distributing patches and posters and busking with songs about corruption, state violence, and social and economic justice are the mediums through which analysis of discriminative structures and processes is disseminated for nonpunk audiences on a daily basis. Yet, it did not result in global hyper-visibility as it had in the aftermath of the December 2011 arrests. This does not mark the punks as exceptional, but rather places them on a continuum of paradoxical politics of (in)visibility and (un)intelligibility in post-disaster and post-conflict Aceh that, for example, 'deviant sexualities' and non-binary gendered people have also faced (Jauhola 2013, 2015b; Thajib 2015; Samuels 2016; Jauhola and Bolong 2017).

When detained and trialled, as the case illustrates, punks negotiate their existence by drawing on gendered support and the transnational social media skills gained since December 2011. These support networks negotiate, on their behalf, punk legality and the right to bodily integrity by engaging with the law 
and legal procedures. This analysis has drawn attention to the overall trend in law enforcement in Aceh and in Indonesia, in which drug-related disputes in the urban post-disaster and post-conflict city of Banda are connected with a wider Indonesian phenomenon wherein significant control of urban space and political economy is in the hands of a 'rogues' state' (Barker 2009). This formal invisibility, or silencing, blurs the existing hierarchies and power within a wider drug economy, leaving the link between public officials and organised crime an essential part of the post-conflict political economy of Aceh - untouched (for overall Indonesian analysis of the patterns of violence, and the role of state authority in street violence, see: Lindsey 2001; Wilson 2010; Wandita 2014). It provides no space for reflection on why petty trade in drugs remains a lucrative livelihood option for many in search of a better life, or how Acehnese campaigning to legalise marijuana represents radical resistance to the continuum of violent conflict and political economy.

Marjaana (chat 1 December 2016): Yudi, why do you think police targeted you in 2013? What was their motivation to label you punks as they did?

Yudi: It was all engineered. It was not that police planned it all, but they let this happen and it was wrong.

Yudi (chat 17 August 2017): Maria, can you help me. I am in trouble, I was attacked on Saturday night but luckily I was not injured from the knife. I have already reported this to the police but instead I and suspected friends are being searched by the Social Department. Can you help me, it's a threatening situation. The one with the knife is part of the neighbourhood's youth organisation and RAPI, ${ }^{26}$ and FPI is involved. Here's the copy of my report but all evidence is lost.

\subsection{Chronic - Changing Dimensions through Metal}

We are the time dimensions

From the warrior ancestors

Not from the losers

Defeated before warring

But it happened now

Everything changes

But it happened now

Changing dimensions

And as it happens we run to hide

Forget all of the real past

The ones who are now are changing the story

Feeling heroes though being rogues 
We are the time dimensions

And as it happens we run to hide

All are bastards!!

'Changing dimensions' by Cronic

As the international focus in the aftermath of the December 2011 arrests and re-education focused solely on punk repression, it was quite surprising to me when, during the initial discussions with the punks, the existence of the metal scene in Banda Aceh, including its presence at the December 2011 outdoor event, became evident - so totalising had been the global media attention on punks, and successfully so!

Cronic, CReasi Orang uNIC (Unique people's creation), ${ }^{27}$ is a trash metal act established in 1999, initially by staff of the Banda Aceh-based Casanova studio: Adi (bassist and vocal) and Nindy (drums). ${ }^{28}$ In 2001, Adi established Studio 77, which still exists, providing an important venue for studio gigs and recording sessions for a range of music genres in Banda Aceh. The band lost its drummer Reza in the tsunami and for a number of years it was no longer active. When the studio was rebuilt in a new location in 2007, the band was also reactivated, with new members. Their first EP, Verandah of Mecca, was released in 2008, the second, Dimensi berganti (Changing dimensions), in 2014, and the third, Kundalini, in 2015. In 2017, the band released their single 'Pusaka Raya' ('People's library') and they are currently preparing for the album Prasast $i$ (Inscription). Whereas the street punks of Banda Aceh are predominantly 20-something young adults, Cronic and Catastrophe consist of older and more economically established members who have finished their studies and have a more stable income. Cronic has toured extensively and has also played short gigs in Banda Aceh.

It is striking how the localised moral panic is not extended towards metal music, or its scene and gigs, in a similar way as towards the punks during Illiza's mayoral term. Nor has it attracted global attention from the media as the punk scene has, even though the lyrics of Cronic's songs are as openly critical as those of the punk songs. The most recent single release, 'Pusaka Raya', is a great example of how different forms of art and popular culture in Banda Aceh offer alternative archives of knowledge with which to deal and debate, through songs and lyrics such as 'Dead city', 'Chronic phobia', 'Depression beyond control', 'Deceiving traditions' and 'Moral crisis'. The metal scene, especially the live gigs, also construct urban embodied practices such as mosh pits and dancing, in which aggression can be expressed and emotions collectively displayed (Riches 2011).

In 2014, when the trial and imprisonment of the two punks, discussed in the previous section, was over, an 'Aceh calling' event featuring local punk bands was organised at Studio 77 (Image 8). Punks busked for the price of entry tickets 


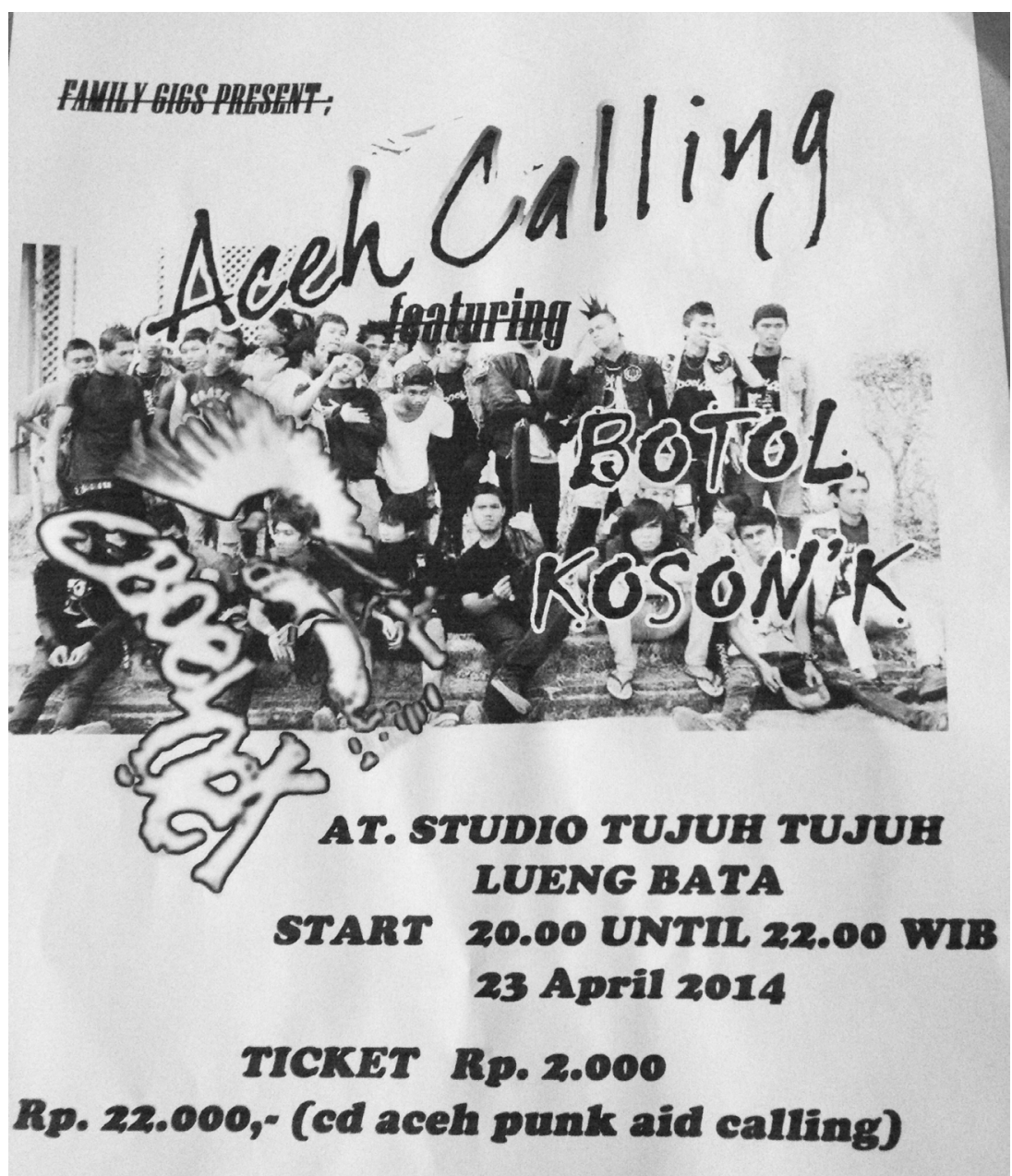

Image 8: Gig advertisement from 2014.

Source: Marjaana Jauhola.

(2,000 Rp., equalling 15 cents) on previous evenings, making sure that they could afford to attend as a group of 15 or so. Interestingly, the event used the same title as the US-based solidarity punk collection from 2012, discussed in the previous section, intertextually connecting the Acehnese punks, once again, to December 2011 and global punk solidarity, but of course also to the classic The Clash song 'London calling. This time, however, it was a local studio gig.

The gig itself was an intense and sweaty moshing experience: the live recording of the song 'Bastard Illiza' provides just one example of this. My mobile 
phone and video recording application jammed several times due to the high temperature in the small studio room, and at times the atmosphere became quite overwhelming, particularly to someone who does not regularly practise moshing. As earlier metal and punk scene research has described it, however, such an intimate space allows the expression of and experimentation with embodied existence and connectedness (Riches 2011). Again, I make this observation without overlooking potential internal conflicts and disagreements or gendered hierarchies among the crowd, but, rather, to emphasise a momentary break of order within chaos, losing oneself to regain oneself collectively:

Chakra of life
My life on the eternal earth
Eternal energy
My immortal art/creation
Internal for humanity
There is a soul and the body
Horizon of the universe
Towards the thorns
Kundalini, true energy
Kundalini, cursory soul
Kundalini, true energy
Kundalini, cursory soul
This is my earth, my land
This is my house, my throne
To be with you
With my Kuntara
This is my life, my death
This is me, my Lord

'Kundalini' by Cronic

\subsection{Difference Is Not a War}

Learning is not the enemy respect it, do not abuse/scold it clear observation, total with clarity of course there are differences yea, your narrow thinking does not accept difference I am proud with my principles 


\section{DIY guides me \\ difference is not a war, when he was born it already existed \\ difference is not a war, yea, we do exist \\ 'Difference is not a war' ('Perbedaan bukan perang')}

This adapted version of the famous sosial sosial band's song was sung at the Tsunami Museum in 2013 by Muhammad, right after he was assaulted by plain clothes military police. The lyrics focus on the idea of alternative knowledge and learning practices, suggesting that communities, such as those represented by the punk and metal scenes, actively establish an archive of knowledge that can travel through punk and metal aesthetics via patches and DIY shirts, and increasingly in the circulation of social media. This chapter has aimed at arguing that seeing the punk scene solely from the perspective of the spectacle of the December 2011 arrests and re-education loses the analytical precision that punk's and the metal scene's mundane everyday praxis entails. Vibrant subcultures that offer their own analysis of power, and thus, offer insights into what meanings of being a punk or a metal fan are gained in the specific context of the aftermath of tsunami and armed conflict - culturally, socially and religiously. 


\section{Queer Community and Care}

\section{Being and Belonging in the Verandah of Mecca}

\section{1 'Queering Peace' in Aceh? Reflecting on Theory and Methodology}

Marjaana: Rek [clapping hands to signal the sync of video and audio recording].

Raiz: Good evening viewers, my name is Raiz from the [video, Coaching to be strong transman]. I am going to announce the dissolving, I mean the establishment, of a new state. Its name is Iks. I am here with Madam E, the President of the State of Iks. Please, Madam.

E: Hi [laughter].

Raiz: Madam E, what is your opinion about the establishment of your state?

$E$ : What [not clear recording]?

Raiz: Oh yes, it is a dream state (idaman) [laughter]. In what ways will you develop your state?

$E$ : The dream state that I will build will be, where will it be?

Raiz: What do you mean where? Where is it? [laughter]

$E$ : I don't know what or how that state can be!

Raiz: Ok, fair enough.

$E$ : I have a plan, but ...

Raiz: Ok, if you cannot answer that, I will move on to the Ambassador of Finland ... here we have Madam Marjaana who represents Finland. Good day Madam!

Marjaana: Good day!

Raiz: How do you feel about the day?

Marjaana: I ... am ... so happy about this; I am so happy I could take part in this occasion. Formally I wish to hand over my diplomatic accreditation to become the Ambassador of Finland in this new state [laughter]. 
Raiz: Ok, I have received your letter, and want to ask you, what is your opinion about this new state?

Marjaana: So happy, because for so long, the situation in the streets, houses, everywhere, has not been secure for friends. I know for sure that this state will guarantee the safety of everyone, regardless of their gender, regardless of their body, regardless of their conduct; it will always be safe for everyone.

Raiz: You are such a good person [laughter]. Thank you for your attendance. Madam President?

$E$ : Me, the president? What are you talking about? [laughter]

Raiz: I end this interview about the new state here. Until later! [laughter] ${ }^{1}$

This tongue-in-cheek video of an imagined press conference was recorded after two intense days of recording the video, Coaching to be strong transman. Set in a noisy restaurant replicating the style of a 1950s American diner, it was prompted by the observation that we had quite accidentally set up the last scene of recording to replicate a press conference: three people sitting on one side of the table with a big audio recorder on a stand in front of us, just like a formal interview with heads of state. Improvised and recorded in one shot, it was full of laughter, playing on the roles of a TV reporter, a reluctant president, and a willing and overly optimistic, newly accredited, CIS-female Nordic ambassador promoting LGBTI rights through a foreign and security policy agenda (Lind 2014; Weber 2014). It was recorded knowing that it would not be used publicly as part of the actual video in the making. However, this clip of just 2.5 minutes offers an interesting transition from the narration of queer experiences in Aceh to the world of liberal peace-building and combatting homophobia with homonationalism (Puar 2007, 2018).

During the period of conducting life historical ethnography in Aceh, the use of the term 'queer', as in 'queer theory' or 'queer research', has emerged in the discipline of International Relations (Richter-Montpetit 2017; Rao 2018), but also more generally in international development and humanitarianism debates: on post-war reconstruction, but also on refugee protection and human rights work (Nasser-Eddin et al. 2018). The emerging scholarship and policy debates address a number of different (academic) audiences: firstly, widely understood 'feminist/queer IR' (Peterson 2014; Sjoberg 2014; Weber 2014; Wilcox 2014); secondly, scholars working with the theme 'Women, Peace, and Security' or UN Security Resolution 1325 (Hagen 2016, 2017); and, thirdly, scholars debating state sovereignty (Weber 2016).

More recent analyses by Melanie Richter-Montpetit (2017) and Rahul Rao (2018) suggest that a fault line of tension between LGBTI Studies and Queer Theory has emerged: on the one hand, some research reiterates the need to 'include' or 'mainstream' or 'integrate' LGBTI concerns and rightsbased agendas with those of global politics, peace-building and post-war 
reconstruction (Hagen 2016, 2017); on the other, the queer approach focuses on questions of how 'normal' and 'perverse' are constructed in global politics, state building and sovereignty. Richter-Montpetit and Rao both suggest that the former approach grounds concern for LGBTI rights and their global acceptability in Eurocentric notions of progress, liberal-political systems and ideas of modernity, which in turn echo imperialist understandings of the West as the telos of global queer struggles (Rao 2015, 2018, 141) - classically exemplified by the press conference discussing the newly founded state of Iks. The silencing effect of LGBTI rights agenda has multiple levels, and lacks both theorising on non-Western models of post-colonial statehood and citizenship and nuanced understandings of lives lived outside the frame of state-driven LGBTI identity politics (see also Jauhola 2013). Meanwhile, as Rahul Rao (2018) illustrates, 'queer separatism' - the demand for self-administered territories for LBGTI's fleeing persecution, as promoted by the Gay Homeland Foundation - has emerged, occurring at the same time as states are expected to take a legislative stand for or against the promotion of LGBT rights, decisions which are then used to measure their level of tolerance in the global order (Rao 2018, 140).

The recording of the launch of Iks coincided with further calls by Indian scholar and activist akshay khanna (2016) for a total reconsideration of the concepts of sexuality and gender non-conformity, outside of Western epistemology and the compulsory 'Western' gaze that creates 'binaries such as male-female, public-private, homosexual-heterosexual, gay-straight and homoerotichomosocial' (khanna 2016, 10). khanna, therefore, suggests that gender and sexualness in a non-European context cannot be analysed and understood in the same ways as they are in Europe and North America, or as the UN or global LGBTI campaigns may suggest.

Similar concerns are reiterated in a number of ethnographic studies that draw on the contextualised lived experiences of self-identified, same-sex loving or gender-variant individuals (Nyanzi 2013; Thajib 2014, 2015, 2017; NasserEddin et al. 2018). In the work of these scholars, the focus is on a careful crafting of analytical frameworks depending on cultural and political contexts. Khanna further suggests that the concept of 'sexuality' should be used to refer to an aspect of personhood; in other words, it is part of the ontology of personhood, 'as through who or what one desires or fucks defines what one is' (khanna 2016, 11, emphasis in original) and, therefore, is intimately linked to a capitalist political economy in which the human body is perceived as the foci of consumption and pleasure (ibid., quoting Katz 1990, 12-13). 'Sexualness', khanna suggests, 'escapes such framing of sexuality, desire and eroticism that flows through people without constituting them as subjects' (khanna 2016, 12). Here, khanna is referring to diverse practices, idioms and language, including launda naach, the erotic dance by effeminate adolescent 'boys' at marriage celebrations or in theatrical performances in different parts of India. Likewise, as I have 
discussed earlier (Jauhola 2013, 59-60), in Aceh a number of similar practices have existed historically that have also, along with open identity politics, such as gay, lesbi and LGBTI, become targets of regulation and governmentality that aim at the 'cleansing of locally defined masculinities, femininities and sexualities' (Peletz 2002, 257). In this chapter, I describe lives and practices taking place in a context wherein governmentality not only targets liberal claims for LGBTI personhood, but is also suspicious of everyday praxis.

It is also important, however, to understand how 'queer' and understandings of temporality (Halberstam 2005) in Aceh are by no means a linear narration of progression or deterioration for queer rights - or well-being, for that matter. Instead, understanding temporality and belonging as 'out of time' (Rao 2020) suggests that lives and experiences may vary, and analytically it is important to be aware of the tendency to view the experiences of non-Europe through liberal Western analytical lenses, which often reiterate homophobic and racist frames. Rao's (2019) review article, focusing on recent critical takes on coloniality and subject positions that have been marginalised by Western temporal imaginaries, offers both an understanding of how 'subjects in these locations are placed behind or outside time, but also how they "defied, deflected and appropriated" their temporal emplacement' (Rao 2019, 305). Furthermore, he adds, in this entanglement, traces of self- and world-making become evident that 'lurk in the timespaces external to the chrononormativity of state and market in which marginalized subjects typically find themselves' (ibid., 307). In fact, the liberal logics of queer/LGBTI visibility and recognition, evidenced, for example, in HIV/AIDS epidemiological registers and LGBTI rights registers (khanna 2016, 6), may give rise to new forms of vulnerability, but also new forms of collective care, as earlier research in Aceh has illustrated (Jauhola 2013; Samuels 2016). As I narrate in the following, research and academic practices can in fact contribute to creating such temporalities and belonging.

All the above-mentioned tensions, visions and paranoias about the wrong kind of visibility and the violent reframing of non-European sexualness were tangible when I participated in the Annual Convention of the International Studies Association in 2016, where a life-history video, Coaching to be strong transman, was premiered. The video and my paper were discussed in a panel entitled, 'Queering peace: a preliminary foray into LGBTI research in conflict and post-conflict areas'. My contribution focused on the vulnerabilities that ethnographic research on gender and sexualities, or a conceptual focus on LGBTI as a primary analytical concept, may cause. In another panel, to promote the special issue titled 'The futures of women, peace and security' in International Affairs (92(2)), my role - reflecting my article in the special issue - was to discuss the necessity of decolonising peace-building (Jauhola 2016); meanwhile, another panelist (Hagen 2016) spoke with the language of queering women, peace and the security agenda, specifically focusing on the need to speak of LGBTI individuals, and their experiences of violence and inclusive 
peace-building. The moving ethnographic and audio-visual research encounters brought into such international academic conference spheres position and frame the material in uncomfortable and problematic ways. ${ }^{2}$ Despite the plea that the paper on queer vulnerabilities in Aceh, read by the panelists, the chair and the discussant, should not be shared or quoted outside the panel, two years later, I found a reference to my paper in a study report of an international organisation working on peace, sexual orientation and gender identity themes. Yet again, I felt that the 'do no harm' principle was becoming impossible to follow, as visibility and the sharing of knowledge is an essential, if violent, part of the research endeavour.

As discussed in earlier chapters, having studied the gender advocates and the politics of gender in 2006-2009, I returned to the city of Band Aceh in 2012 to explore how the biopolitics of reconstruction materialises in the everyday lives of those labelled as outcast or improper, or who are in one way or another condemned as dangerous to imagined Banda Acehnese subjectivities, the result of a 'purification of society' (Thajib 2014, 161). Yet, although violent governmentality seeks to punish and purify LGBTI subjects, my analytical focus has been dual: firstly, on processes of normalisation as potential sites of social violence, with an emphasis on particular locations and contexts in which certain subjects are rendered 'normal' and 'natural' through the production of 'perverse' and 'pathological' others (Eng et al. 2005, 1-3); and, secondly, on how individuals navigate their everyday lives in and out of these normalisations, making lives liveable outside the gaze of liberal visibility politics (Jauhola 2013, 29, 78). The tendency to see sexual morality through the lenses of the West is very powerful, as many of the human-rights-based organisations in Indonesia, including those that label themselves as promoting 'LGBTI rights', narrate the situation as a linear worsening of the security and well-being of queer-identified people (Jauhola 2013).

As discussed elsewhere (Jauhola 2013; Daly et al. 2016), during the five years (2005-2009) of tsunami reconstruction funding, 'gender activism' became a highly politicised issue in Aceh. While tsunami funding for NGOs and women's activist groups expanded spaces in which gender norms had been discussed since the late 1980s to include tabooed and marginalised forms of femininity, masculinity and sexuality, ${ }^{3}$ this took place when, in other circles, the blurring of gender boundaries and sexual immorality was seen as the cause of the disaster and as a danger to Acehnese society and the nation (Jauhola 2013). Using the example of the waria ${ }^{4}$ anti-poverty theatrical act, queer readings of the Qur'an and Acehnese history, and emerging forms of organised Acehnese LGBTI activism, I have previously discussed the possibility of seeing such events and processes as an extension of Boellstorff's notion of a 'gay archipelago' (Boellstorff 2005b). This metaphor refers to subjectivities that negotiate the meanings of sexuality and nation by appropriating and reworking global concepts, such as gender or LGBTI, but also Islamic traditions and Quranic jurisprudence and Acehnese history. ${ }^{5}$ 
I remained cautious in my analysis, however, of the transformative possibilities of queer logics that depend on state recognition and visibility (Jauhola 2012, 2013; Samuels 2016), mainly due to the new logics of control and surveillance, vulnerabilisation and normalisation, that gay and waria visibility was bringing to queer everyday life in the city. At that point, my ethnographic data drew attention to the invisible: desires and bodies that were carefully protected from outsider eyes, including mine, of tombois, but also female-to-male transgender, priawan ${ }^{6}$ or transmen, as many would later call themselves. This, I argue, has several consequences for the focus of the ethnography and analysis of the research data - which to me, form an intimate part of 'queer ethics': firstly, resisting the tendency to assume that LGBTI involves the singular existence of a global gay subject (Rao 2015, 403); secondly, placing a decisive focus on the less visible community of tombois and transmen/priawan and the ways in which they negotiate queer spaces in Aceh, and resisting the tendency to treat the LGBTI community as a coherent and shared space of queerness; thirdly, widening the understanding of the 'queer' to various others who, in the current logics of sexual politics, are regarded as outcast, dangerous or unwanted Acehnese subjects (see, e.g., discussions in Chapters 3, 4 and 5). Thus, at the core of this life narrative approach are lived experiences that are articulated in the complex interplay between subject-abject, local, regional and global, conflict, natural disaster and its reconstruction, practices aiming to govern life and death and render bodies biopolitical, and the desire to live, love and gain recognition for such a life in the aftermath of the armed conflict, Indian Ocean earthquakes and the tsunami.

This chapter focuses on the post-conflicted gendered and sexual politics in Aceh from the point of view of the queer: LGBTI activists, but also nonactivist individuals who do not conform to heteronormative and binary gender ideas promoted by post-conflict legal frameworks or their advocates. As with other marginalised subjectivities, the paradox of visibility follows queerness in Aceh: becoming visible is required in order to receive care or gain access to basic social, political and economic rights, and thus forms an important part of advocacy, for example, with regard to HIV/AIDS or demands for access to education and livelihoods. Yet, this same visibility causes discrimination and the fear of exposure in individuals (Samuels 2016, 105). Thus, the story that unfolds here can be read as an awkward paranoia and as embodying the pain of (re)creating unsafety and negotiating the principles of respecting and maintaining safe spaces and invisibility, meanwhile meeting the desire to be heard, understood and visible.

By following the queers in the city, the ethnographic journey explores what the process of drafting the Islamic Criminal Law (Qanun Jinayat), Indonesian national anti-LGBTI sentiments, the specific campaigning of the Hizbut Tahrir Indonesia in Banda Aceh and the vigilantism done by Islamist movements such as the Islamic Defenders Front (FPI) has meant for bodies and desires that do not conform with legally regulated bodies. Moving from activist spaces and spheres 
to beauty salons and contests, via hazardous wage labouring (see Chapter 7) and care for others, these snippets of life histories draw attention to the multiple faces of the queer in Aceh that cannot be reduced to a narrative of LGBTIs in need of saving, let alone a homogenous group whose demands, dreams and fears can be easily translated into 'global LGBTI' advocacy vocabulary. In fact, earlier research on the queer in Aceh illustrates that understandings of gender order and forms of sexuality are far from simple; rather, they have included a number of local practices of same-sex desires and fluid understandings of gender, in particular in relation to the religious and cultural practices connected with heteronormative marriage (Jauhola 2013; Thajib 2017). Before moving on to focus on the praxis of care and community, the next sections discuss the colonial histories of governing gender and sexuality, and the more recent context of the politicisation of gender and sexuality in Aceh over the past few years as part of negotiating the settlement of the armed conflict.

\subsection{Queer Aceh}

No in-depth historical research has been conducted on the legacies of colonialism or the practices of gender and sexualities in Aceh during colonial times and the Acehnese Sultanate. Yet, Aceh has always had notions of mutability with regard to expressing gender, and earlier research indicates a fluidity of sexualness or sexualities, expressed through folklore, dance and music traditions and manuscript literature, and also evidenced in colonial studies of the courts of the Sultanate and Acehnese communities (Jauhola 2013, 60, 84). Without making any assumptions of lived or recorded life experiences, this flexibility - at least in the ritualistic, folkloristic and oral historic spheres - contrasted with the situation in the Netherlands where sodomy (anal penetration, active or passive) was a capital offence, with historical links to Roman law and medieval canonical law (Boomgaard 2012, 143; Murrell 2013, 12). Those found guilty of the 'error of nature' (Voltaire 1764, quoted in de Jong 2011, 55) were executed after torture in brutal and dishonourable ways. Such punishments were, at the time, justified in order 'to stop the corruption of society and to avert God's anger and punishment' (de Jong 2011, 56). According to Murrell (2013), this may have led to an increased number of homosexuals seeking service in the East India Company (VOC, Vereenigde Oost-Indische Compagnie, established in 1602), ${ }^{7}$ in response to Dutch sailors reporting the tolerance of homosexuality in Asian societies (ibid.); this may, in turn, have contributed to the intimate place in empire-building activities of homosexual acts (Boomgaard 2012, 143).

Court archives have references to same-sex relations between the Dutch in homosocial spheres both voluntarily and 'situationally' - that is, due to a lack of alternatives - in hierarchical and economic arrangements (same-sex intercourse in exchange for money) with so-called indigenous populations (Boomgaard 2012, 142-143). Most well-known of the 17th-century VOC 
sodomy court cases involves a member of the Council of Indies, one Joost Schouten, who was sentenced to death in 1644 after voluntarily admitting to having been 'used as a woman' while travelling on board between Aceh and Malacca in 1641 (ibid., 14). ${ }^{8}$ In 1641, during his visit to recently conquered Malacca, he had made a commercial agreement with the first female Sultanah of Aceh, Taj ul-Alam Safiatuddin Syah, whereby exclusive trading rights were granted to a VOC ship (Khan 2010, 19). By the mid-1640s, just prior to his sentencing, Schouten had become a powerful and famous member of Batavian society (Murrell 2013, 13).

In the 1920s and 1930s, a number of Europeans considering themselves homosexuals had found their way to the Indonesian archipelago, particularly to Bali. Towards the end of Dutch rule, 'a crack-down' on homosexuality was enacted, an episode that included the unsuccessful attempts by anthropologist Margaret Mead to save German painter Walter Spies from being put on trial and imprisoned (Boellstorff 2005b, 52-54). As with the early history of gender and sexuality, the early years of independent Indonesia are little studied, but it seems that the terms 'homosexual' and 'homosexuality' were intimately linked to the European presence, despite the diversity in expressions, traditions and practices across the archipelago (ibid., 55). Female same-sex relations were demonised in public discourse at the time of the events of 1965, the killing of eight generals. The government campaigned that the killers of the generals, members of the women's communist party organisation Gerwani, had had same-sex orgies, leading to strong labelling of them as 'improper' and eventually leading to their execution (Wieringa 2002; Boellstorff 2005b, 55). After this demarcation of female sexuality in particular, President Suharto's regime, known as the New Order (1965-1998), made an active attempt to mould the modernisation and economic liberalisation agenda around the figure of the ideal woman, wife and active citizen in a nuclear family (Robinson 1995).

As discussed in Chapter 3, the legitimacy of forms of gendered expression, sexual intimacy and conjugal practices is currently governed by the legal framework put in place over the past 17 years as part of the peace negotiation processes concerned with the special status of Aceh within the Republic of Indonesia. A focus on sexual morality has been at the centre of this reform. But it was not until 2015 that the provincial legislature successfully ruled that consensual same-sex practices were illegal, for the first time in the history of the republic. During the first years of the law's implementation, Acehnese legal experts have remained optimistic that its power remains merely preventive, as it is unlikely that cases with sufficient evidence (four male witnesses) will ever be brought to court. It has, however, had concrete consequences for the sense of well-being, access to public space and services (such as health and education) and available livelihoods for anyone who is suspect. This is largely due to simultaneous calls by the Mayor of Banda Aceh and Islamic organisations, such as the Hizbut Tahrir Indonesia (HTI) and the FPI, for neighbourhood LGBTI surveillance, the documentation and reporting of suspected LGBTIs to 
the authorities and the establishment of multi-expert teams to instigate conversion (referred to by the mayor as the 'return to the right path of Allah'). Since 2016, several arrests of suspected gays have taken place in different urban towns in Aceh, all of which have gained the attention of international human rights organisations and the English-speaking media.

Furthermore, the timing is not coincidental. In fact, it seems that whereas it was the street punk community that became the target of moral policing around the time of the 2011-2012 elections (see Chapter 5), the suspected LGBTI were chosen as a campaigning tool for the 2017 elections (for which the candidature process began in April 2016), and again in 2018 when the candidature process began for the 2019 elections. Indeed, a focus on morality, sexuality, sociality and the vices of the younger-age cohorts have been an active part of post-conflict campaigning (Jauhola 2011) in a context where political parties and their candidates actively seek endorsement from religious leaders, who in turn have an important role in influencing the electorate and thus, indirectly, election results.

Over the past two years, however, using LGBTI bodies and their desires to mark the boundaries and fragility of the nation (Berlant 1995) has intensified both in Aceh and in Indonesia as a whole. The political elite uses the acronym LGBTI to demarcate culturally and religiously unacceptable behaviour and identities, calling LGBTI activism a form of terrorism and proxy warfare used to brainwash Indonesians by the Western powers (see also Boellstorff 2014 for the emergence of the use of 'terrorism' in LGBTI moral panic). When, in 2012, openly gay activist Dede Oetomo was a candidate for the Human Rights Commission of Indonesia, the media provided widely negative coverage of his candidacy. Meanwhile, the Acehnese Muslim Students Association (KAMMI) publicly condemned the candidacy with a protest organised at the demonstration 'hot spot' in town, Simpang Lima (see Chapter 2 for more of the uses of public spaces for political engagement and visibility in the city); a representative of the association was documented saying 'we reject gay and other members of the transgender community entering institutions like Komnas HAM, because it will mar the state's integrity' (Tempo.co 2012). Whereas during the earlier years these comments mainly came from the Islamist mass organisations and conservative Indonesian Ulama Council, by early 2016, such remarks clearly indicate the expansion of the view that the 'presence of sexual minorities in the national public culture [was] a threat to regnant masculinist and heteronormative logics of national belonging' (Thajib 2014, 160). 'Political homophobia' (Boellstorff 2004) was now articulated by ministers, members of parliament and state bureaucrats, leaders of the largest Muslim mass organisation, the NU, the Indonesian association of psychiatrists and the Indonesian Broadcasting Commission.

This list includes one of the 'masterminds' of the Aceh peace process: VicePresident Yusuf Kalla, having requested that the UN Development Programme in February 2016 withdraw any funding for LGBTI campaigning in Indonesia 
as they did not reflect the social values of the nation, later amended this, admitting that a former minister had been gay and that Indonesia, compared with Malaysia, is tolerant, as homosexual acts are not criminalised. This statement does several things: firstly, it continues a long debate about diplomatic conflict and differentiation between Malaysia and Indonesia; and, secondly, it actively ignores the legislative reforms that have criminalised homosexual acts in Aceh, which are in fact the result of the peace process in which he played a central role. Kalla's final remark for the journalists reiterated the dominant Indonesian logic of dealing with homosexuality, 'don't ask, don't tell': 'if LGBT remains a personal issue, then there's no problem.' This negative sentiment was challenged by the Minister for Political, Legal and Security Affairs, Luhut Pandjaitan: 'Whoever they are, wherever they work, he or she continues to be an Indonesian citizen. They have the right to be protected as well.'

These most recent public negotiations between nation, morality, authenticity of culture, Islamic jurisdiction, sexuality and gender expression took place at the same time as a number of other events, such as regional and national advocacy on the same-sex marriage acts and Jakarta-based civil society strategic planning for advocacy on a legal framework for women's and LGBTI rights. At the UN level, there was visible endorsement of LGBTI in the context of the post-2015 agenda, with the statements of the World Bank Group's President, Jim Yong Kim, on conditioning loans to LGBTI harm assessments at The Economist event, 'Pride and prejudice: The business case for LGBTI diversity and inclusion'. The February 2016 release of UN stamps and a new campaign Free \& Equal (unfe.org) celebrated same-sex intimacy, parenting and transgender, producing a global ranking order based on LGBTI rights, as Rao $(2018,140)$ puts it. The launch of the UN stamps was greeted by protest from the Group of Friends of the Family and the Organisation of Islamic Coopration(OIC), Indonesia included, which made it into international media circulation, but apparently was not covered at all by the Indonesian media.

Similarly, demands to include LGBTI or SOGI (sexual orientation and gender identity) concerns into the ASEAN human rights declaration in 2012 caused considerable reaction among the region's governments. Six ASEAN member countries have national or local laws criminalising same-sex activities between mutually consenting adults: Brunei, Burma, Malaysia and Singapore, Philippines (in Marawi City) and Indonesia (in South Sumatra and Aceh). Most recently, in 2018, an 'Asia-Pacific consultation on the inclusion of LGBTIQ communities and promoting LGBTIQ rights in resilience-building, response, and recovery interventions in humanitarian settings' was organised in Bangkok as a result of collaboration between the Asia Pacific Transgender Network, the ASEAN SOGIE caucus, APCOM, Edge Effect, International Planned Parenthood Foundation (IPPF) and UN Women. ${ }^{10}$

For anyone who has followed the global dynamics of the politics of gender and sexuality at the UN forums, especially those of World Conferences, such as the International Conference on Population and Development in Cairo and 
the UN Fourth World Conference on Women in Beijing in 1995 and onwards, would recognise that the content of family, gender and sexuality concepts are the subject of continuous struggle (Jauhola 2010, 30-31; see also Bunch and Fried 1996; Baden and Goetz 1997). ${ }^{11}$ Acehnese queer activists also followed the news from Russia banning the 'homosexual propaganda' (Tribunnews.com 2013) as social media not only enabled news from Aceh to become international news, but facilitated the reverse, introducing quite polarised news on the topic from other contexts. In the mid-1990s, during the Asia Pacific preparatory meeting for the Beijing conference in Jakarta in 1994, the Minister for Women's Affairs specifically marked the boundaries of nation and sexuality in the following way:

I cannot accept them [lesbians] as Indonesian women. My belief is that lesbianism is not in accordance with pancasila [Indonesia's five-point state ideology], because lesbians have forgotten their fundamental duties to be mothers, giving birth and raising children.

Quoted in Gayatri 1996, 86

What has changed since 1994 is that LGBTI, and lesbianism for that matter, is no longer condemned on the basis of heteronormative pancasila state ideology, or failure to perform the five duties of women (dharma wanita), ${ }^{12}$ but on that of authentic Indonesian/Acehnese culture, religious norms, psychiatry and moral panic (see Thajib 2015 for a more detailed account of the changes in discourses that regulate homosexuality in Indonesia).

\subsection{The LGBTI Activist City}

After initial online introductions to the LGBTI activists in 2012 through a common friend, I was invited to visit 'the office. This meant that quite a big change had taken place since my last visit to Banda Aceh in 2009: lesbian, tomboy and transmen-identifying activists were now actively organising themselves under the wider 'Queer NGO'13 umbrella with their own groups and activities. Having received instructions on how to reach the office, I headed towards an upper-middle-class neighbourhood that, during the height of the post-tsunami reconstruction aid years, was known for accommodating several international NGOs and their expatriate staff, including myself. As I was dependent on public transport and motorbike taxis (becak), I was worried about the visibility my visit would give to their office. Assured that there would not be problems, the meeting was confirmed.

On my way, despite my instructions, the becak driver and I became lost in the narrow neighbourhood roads and intersections and, finally, to reach the house, one of the transmen gave phone instructions to the driver. I disembarked in the front yard of a post-tsunami reconstruction house that appeared to be a home: laundry drying on a rod in front of the house and curtains in the window. Still 
not sure if I was in the right place, I called my contact, who came outside, greeting me and the becak driver. Waiting for the driver to take off, I felt nervous and apologised for the mix-up, while thinking of the worst possible consequences: the organisation had changed its office location multiple times within the city, mostly when the neighbourhood or the landlord had requested its departure because its activities had become too visible or known. I made a mental note of this awkwardness and permanently changed my strategy for reaching new destinations: never arrive at a new place with outsiders, and think carefully about whether witnessing authentic places in the name of ethnographic experience potentially compromises the safety and its longevity of those researched.

I sensed that the 'climate of fear' (Thajib 2014), the awkwardness of not knowing the consequences of visibility and the 'stickiness' of the visible white body, was shared by me and my host, a situation that continued throughout most of the other ethnographic encounters I was to have with transmen over the next few weeks in Banda Aceh. In fact, one year earlier, when I conducted interviews with Acehnese LGBTI activists outside Aceh, they told that many of their internal training activities and gatherings had been moved outside of Aceh, mainly for security reasons (fieldwork notes, 4 June 2013).

I stepped inside a vibrant office and joined a meeting. We introduced ourselves and after an hour's conversation, we agreed that we would continue discussions using chat, arranging where to meet and talk later. In 2012, despite these feelings of awkwardness, we had still decided to explore the city together on motorbikes: moving about different parts of the city that one of them had regarded as important for his everyday life. Exploring the city together always carried the sense of temporality and alertness - as the Sharia Police (WH) was known to patrol certain locations in town that young adults and adolescents used for after-school and after-work recreation. This all happened before the municipality announced a 9 pm curfew for women in 2015 (which was extended to $11 \mathrm{pm}$ after a national-level social media/Twitter campaign and TV media attention).

Before the actual physical threats to queers in Aceh, and due to decreased ad hoc international funding since the closure of tsunami reconstruction, the leadership considered alternative funding innovations, such as founding a modelling school, both as a source of livelihood and to provide space for local activities. For the following few years, queer visibility and safe spaces ${ }^{14}$ for organising and holding events increased, not directly under the banner of 'LGBTI activism', but under that of modelling, fashion shows, dance competitions and performances. I observed a couple of these events as part of my ethnography: the outdoor TV screening of an Indonesian-wide beauty pageant where the Acehnese representative was coached and styled by the modelling school, as well as dance events. My participation was always negotiated beforehand and usually I took on the role of 'inquisitive tourist/university visitor' as the ethnographic fieldwork was spread over three years. Most of the discussions and sharing of experiences would take place afterwards using mobile 
phones and social media. From our first meeting in 2012, the issue of the difficulty of moving in bigger groups of transmen/tombois in public was raised, as it attracted more attention than being alone or with just one feminine friend. The compulsory heteronormativity provided some limited safety in town although there was always the fear that the $\mathrm{WH}$ would stop them due to khalwat suspicions (proximity between non-married two-gender couples).

The following two sections address themes such as desire, care and building belonging and connectedness through poetic language expressed in the spaces to which I was allowed access. The sections are deliberately reconstructed in ways that do not reveal individual life trajectories, locations or livelihood choices. Rather, by zooming in on the mundane and intimate, they aim to highlight that, despite the pressures of governance, control and vulnerabilisation, queers still seek out beauty, love, community and safety.

\subsection{Becoming Tomboi and Transman in Aceh}

It's 2013. We sit in a noisy fast-food chain restaurant, right under a speaker that blasts music into our ears, but also into my recorder on the table. The loud sound protects our discussion, but also makes the recording a safe archive; when I return to it later, I realise that it is very hard to understand at all what was discussed. Ironically, the failure to follow standard instructions of good audio quality when recording an interview - never record in spaces that are loud - renders this encounter, or the traces of it, a safer archive than if it were a neat sound track stored on my computer or external hard drive. As I am writing this section of the chapter in 2019, I see that after years of having lost contact, they ${ }^{15}$ (my interviewee) have just reconnected with me on Facebook and I make it mutual.

We got to know each other on Facebook, but, prior to the fast-food restaurant, we had never met before. The person I am talking to here in 2013 - let's call them 'Babe' in this chapter - has left Aceh. Perhaps primarily to study, but in their narrative I also sense the need to create distance from the queer activist circles of which they were once an intimate part. Over the years, I have sensed that stories of that distancing vary, depending on who is telling them. Were there misunderstandings about how to run the organisation, or was it more about ways in which intimacy and relationships were becoming complicated, and not always harmonious and non-violent? It seems that for some in the organisation, religious beliefs were the dividing factor that created clashes and conflicts - orientations varying between atheism and strong personal religious beliefs. Regardless of what the 'truth' may be, there in 2013 I am told the story of becoming a queer and what life seems to offer right now. And then, after five years of not being in touch, in 2019 we return to the period in between, and how Babe is now.

Born in Aceh and educated there, Babe's family is important for both religious and economic reasons, as both have allowed entry into higher education and 
more freedom to do things, as long as a career is being built and the religious quest for piety adhered to. The high socio-economic positioning is performed through the designer watch and clothes frequently exhibited by Babe on their Facebook profile. The becoming queer story constructs the narrative, but also connects the embodied self to places, global discourses on LGBTI and older people who have supported the journey of searching for 'who I am'. Religious boarding school, or pesantren, provided the first experiences of girl-to-girl intimate relations (see, e.g., Dzulkarnain 2006; Zuhri 2006; Zuhri 2006; Dzulkarnain 2009; Nurish 2010, 272-273), but also included experiences of violence that have left their marks of distrust and maintaining distance. The internet and movies have provided space to mirror personal experience, and to find a vocabulary for thoughts and feelings. Meeting with the Indonesian key gay activist Dede Oetomo from Surabaya (an important senior 'outed figure' from whom to learn), as for most Indonesian LGBTI activists, had provided the strength to create a space in which to share the experiences of queer lives, but also violence. Right now, in 2013, celebrating IDAHO (International Day Against Homophobia on 17 May) is an important way to create a community and share positive support, tolerance and boundary breaking, but raise awareness on how both religious leaders and psychologists are trying to cure the queers.

Yet Babe has grown up in a religious family where their own brother is an important Ustad, religious scholar, but the religiosity so far has included space for differences and multiplicity and, thus, religiousness and being connected to Ummat are important parts of who Babe is. Nonetheless, the increasing religious intolerance towards LGBTI and the screening of the documentary 'Warna Warni Lesbian' on ANTV had made Babe feel apprehensive about people's increased scrutiny. Earlier, wearing visible tomboy identity signifiers (look like a boy, play with boys) was nothing special. Now, anchoring self-expression in clothes, hair and appearance generally gives rise to insecurity and a sense of weakness, and makes Babe afraid.

In 2013, Babe has been in a relationship with their current girlfriend for a few months; there is no violence, the relationship is smooth and the future plans include adoption of a child. Yet, when Babe describes their relationship, the hierarchical position between the 'male' and the 'female' is described as like that between 'I' and 'child' (anak). It consists of a gendered positioning within the relationship (such as through divisional labour of domestic chores), but also continues the hierarchical yet educational, caring and intimate, seniorjunior same-sex relationships, known as kakak-adik couples in Islamic boarding schools, wherein the kakak are tomboy/masculine protectors, helping the adik in their studies and providing caring attention (see, e.g., Dzulkarnain 2006; Zuhri 2006; Zuhri 2006; Dzulkarnain 2009; Nurish 2010, 272-273). Such practices are being studied as vernacular forms of sexualness known as mairil, dumok, alaq-dalaq, nyempet, muyak lating, lesehan and lesbiola, but increasingly also as 'sexual disorders' (Khaerina and Abraham 2014, 100). 
The description of their relationship is also filled with transnational queer/ LGBTI activist language: Yogyakarta principles, discrimination, concepts such as trans and HIV/AIDS; it is as if the self-awareness that is created through a rhizome of lived experiences, and how they relate to transnational activist and advocacy spheres, creates a language that makes life intelligible, but also relatable and liveable. Yet, at the same time, it also provides the recognition that although such principles affirm the idea of the equality of all, in a context such as Aceh, the realisation of such rights through the protection of the state is impossible to imagine.

Four themes appear in the discussion: work, personality, home and religion, and an ethical non-violent approach to life. Yet, Babe's understanding of home includes the metaphor of an open door: the door is open to come and go - there has to be freedom (to leave) - but it also involves the trust that the one who has walked out through the door will return. To me, this is a metaphor for the fluidity of relationships and intimacies which break the heteronormative replication of queer relations through monogamous marriage or partnership.

Sometimes, during the discussion, Babe's voice becomes strong, incendiary, that of an agitator or advocate, making me feel that this is an activist who in this encounter is self-consciously providing a narrative of becoming and living a life as a queer. In fact, apart from my introduction to what I am researching, I do not pose questions. Rather, I listen and nod and let Babe narrate for two hours.

At the core of the religious, but also nationalist, debates on gender in Indonesia is the concept of kodrat ${ }^{16}$ (Jauhola 2013, 65-66, 71-72), and during our discussion the concept is used in the context of Babe's own mother; caring is something that differentiates human from animal, but, at the same time, exploring personal gendered expression is described through Babe's and their friends' exploration of femininity and masculinity - allowing oneself to explore, as a teenager for example, to test one's gendered expression. On the one hand, there is a need to distinguish human from animal, but, on the other, to recognise that each one of us also goes through the phase of learning about oneself, exploring oneself; in other words, there is no real kodrat to begin with.

When we reconnect in 2019, we have the following exchange:

Babe: Yes, I miss talking about gender. It has been a long time since 2013 never to be involved in the LGBTIQ realm ....

Babe: Incidentally, I have now been intensely hooded, so my old friends accuse me of lesbophobia.

Marjaana: Ohoo, if veiled is lesbophobia? Hmmm why is that?

Babe: Yeah people accuse me of that ... Even though I am still thinking like before.

Babe's social media platform profile portrays a PKS (Partai Keadian Sejahtera, Prosperous Justice Party) presidential campaign frame that advocates the 
change of president (19 ganti presiden). Babe had activated it in April 2018, when the PKS-led campaign went viral. Since 2013, after graduating from her studies at around that time, entry into professional working life has meant establishing three parallel visual lives: firstly, that of a tomboy where the aesthetics are very similar to those of 2013; secondly, that of a professional (the nature of which is withheld in order to ensure anonymity and safety) with job uniforms and close-up photographs of face and work situations; and, thirdly, the full black chodar of attending to religious activities.

Another community member described his ${ }^{17}$ childhood as strictly controlled, yet open within the military structures of the Indonesian army. Rigid rules governing what was permitted and prohibited in life were part of the upbringing, including a ban on crying, even when his father dispensed corporal punishment. Meanwhile, living in a military compound, subject to military middleclass family structures, undoubtedly provided access to privileged places in town, along with the possibility of transgressing certain normative expectations of a gendered child. The photos from childhood all reflect the development of a boyish tomboy. As the town was highly militarised during the conflict, with major sections of it still under the jurisdiction of the Indonesian army, spending time in the city recalls memories from childhood of hanging around in Taman Sari and Blang Padang park. Yet, as the following sections detail, things had changed since the introduction of the Muslim dress code in the early 2000s, and especially after the introduction of Islamic criminal law in 2014. As a result of the violence and surveillance in 2018, he has migrated away from Aceh.

Thus, these two queer life stories, despite access to 'global circuits of queer knowledge' (Blackwood 2008), are actively negotiated and appropriated to suit Acehnese circumstances. I return to this negotiation and appropriation in some of the following sections, as it appears to be the way to craft a queer space that is neither a Western liberal LGBTI subject position nor a homophobic Islamic/ st one.

\subsection{Poetic Expressions of Love, Intimacy and Care}

This section is dedicated to Acehnese queer poetry. As Audre Lorde (2017, 2-3) has put it:

For women, then, poetry is not a luxury. It is a vital necessity of our existence. It forms the quality of the light within which we can predicate our hopes and dreams towards survival and change, first made into language, then into idea, then into more tangible action. Poetry is the way we help give name to the nameless so it can be thought. The farthest horizons of our hopes and fears are cobbled by our poems, carved from the rock experiences of our daily lives.

Let's listen to the Acehnese queer poetry. ${ }^{18}$ 
I'm not even as beautiful

I'm not as beautiful as the wink of your eye

But can you give me a smile

Even though it's not love, I begged

Oo jen bro, han bon jeum eun to ra pwa ju gyet jo

Ooh I'm waiting for you to the end

Oneul do cha, ma mo tan, if you are pretentious, ma'am

Only one word, keu del hamnida

Oh Allah

I wish all is gonna be better soon

Please

Amin

Teenlovefeel:

because women are now very much

Looking at you, you won't find it again in the future. Open your eyes.

Hey you, my heart is dug [sound of heartbeat]

When I see you fall before me

Makes me hurry over to you

Hey you dag dig dug [sensation of rapid heartbeat]

Happy seven-month anniversary, dear. Thanks for everything. Go and be successful ... prayers and inspiration will create shining with more hope but one goal is: IT'S forever and together. Hahaha. I love you more.

O God, thank you for extending my life to reach X. I am so grateful for what you have given me in past years.

You made me a child in a family that is very fond of me, You present me with friends that are so varied that I know and understand the real things in life,

I also offer my gratitude because you bring love to my life so that I feel a sense of happiness and pain from loving and being loved. 
I hope this year you will remain present in my relations with family, friends and have love for me in this life.

Get rid of all the pain I've felt in this period.

Make me happy, lucky, safe and successful throughout my life in the world and in the hereafter.

Amen, Allah.

When I see you, I hold my breath for so long

I keep my steps close to you $\wedge \wedge$

relationship status: 'went from being married to single'

I am returning back to being a citizen of a Social Media Platform right =)

I am restoring relations with all; even though I am certain that they damaged my life, let's be friends, mates and comrades (the question of love comes a bit later)

there is a feeling of pleasure when I see a teenager who is still very young in love ...

they don't care and clearly expresses their feelings

they don't care about the taunts or ridicule of the people around them they knew they were in love...

if we can today be as honest as a teenager about feelings

if we are adults, we ignore prestige to be honest about feelings

maybe our misunderstanding won't be as big as it is now

but whatever the difficulties ...

I feel that I have grown up to keep you

you are the one I love ...

Patience, friend, I know how it feels to be you ...

Pain due to unusual habits

Pain from overconfidence

But my friend made it out of pain with confidence 
I want and can forget it ...

For today, cry hard

Next week laugh at your tears of today

Keep the spirit alive, my friend!!

Even though life is difficult

Although eating is difficult

Even though it's difficult to stop it

But gratitude for being with you is also hard to forget

Hey you who arrive and go

I think you are 'love' in my life

Afraid to cry, I repeat the story

In the end I chose to be quiet

Live the story of your memories of my money

\# still always love you my $\wedge \wedge$

Here, there are many people who have not finished with the struggle in their heart ... unfortunately it is actually making enemies, while on the other hand there are actually some of them who are part of us.

Unfortunately, but as someone who values the process, I understand their fears =)

Happy anti-people who don't like us

My life today feels more efficient than yesterday

I have to be better, that's the point

You mean so much

Special heart

Forever this taste

(kiss) XX 
Unspiritable

This is a rich paparazzi, wow! how come I have a feeling that people are following me and now there are arrests after looking at my photos. Who are those people? \#incident of security

I miss my wife $\mathrm{S}$

From new year starts new life, bismillah

To work here is difficult

To gain a livelihood is difficult

To go out in pants

It's not wrong to do b2b, $\mathrm{f} 2 \mathrm{f}$ and bisexual, sexuality is fluid and we all have same rights, hey, do not bully friends ...

Why so serious ... welcome to the world, hey

\subsection{Knowledge as Violence: Strategy to 'Wipe Out' LGBTI from Aceh}

In 2016, Mayor Illiza Saaduddin Djamal established an LGBTI Aceh Countermeasure Team to eradicate LGBTI from Aceh. As discussed in Chapter 2, she had endorsed the establishment of teams to maintain moral order in the city and its neighbourhoods by implementing amar ma'ruf nahi mungkar (ordering all that is right and prohibiting all that is wrong [Al Imran 104]). The early teams targeted prostitution, gambling, illegal alcohol production and consumption, and also cleared locations used by punks at night (see Chapter 5). They were assigned the recruitment of neighbourhood youth to undertake surveillance of their areas. Furthermore, Friday sermons in the neighbourhood mosques delivered messages that LGBTI was a 'form of terror' (see the discussion in Chapter 3) that must be destroyed. When arrested and interrogated 
by the Shari'a Police, individuals were asked to give details of the community; names and photographs were actively sought from mobile phones and social media applications.

As a disruption to her dominant public image as a calm and smiling leader and role model for piousness (see Chapter 2), in 2016, Mayor Illiza's Instagram account portrayed her as a militant leader, presenting a photograph of her aiming a pistol at a shooting range (Image 9) as a 'hunter' of the LGBTI community, with the following text: ${ }^{19}$

$\begin{array}{ll}21.06 & 59 \% \square \\ \text { (1) illiza_saaduddin } & \text { 1h }\end{array}$
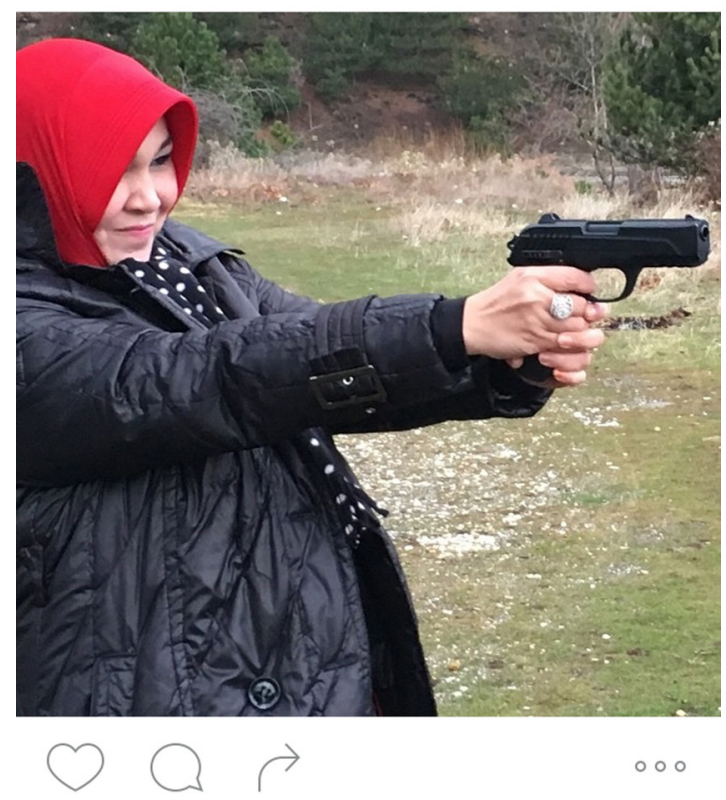

- 269 tykkäystä

illiza_saaduddin LGBT... Enyahlah dari bumi serambi mekah ini...

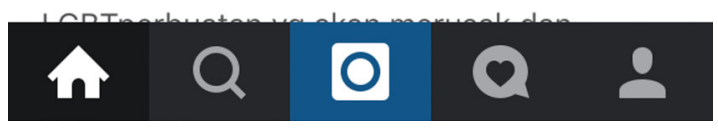

Image 9: Instagram post by Mayor Illiza in 2016.

Source: Instagram of Illiza Saaduddin Djamal. 
'LGBT ... get away from this veranda of Mecca ...'

LGBT acts will damage and destroy the human spirit, because they clearly violate the Islamic law ... Islam puts Akhlaqul Karmiah ahead ... so we in Banda Aceh explicitly reject the existence of LGBT. We hate and fight behaviour that deviates from customary norms and religious norms ... [and LGBT people] which we [also] hate and fight, as they are not human beings. Be aware, return to the right path ... one second, one minute of life is very meaningful for improving relations with Allah SWT ... Allah says ... improve relations with me, so I will improve your relationship with humans .... repent ... read the Qur'an and establish habits of prayer and, God willing, Allah will again straighten our brothers who make mistakes ... Allahu akhbar. Allah inspires the soul with goodness and evil, bringing fortune to those who purify it and it harm to those who contaminate it ... Illiza Sa'aduddin Djamal (Mayor of Banda Aceh).

Screen capture from Instagram, 1 February $2016^{20}$

Apart from the state/municipality apparatus, the local media had also been reporting on the alarming rates of LGBTI in Aceh for years, offering warning examples of how youngsters become LGBTI and raising the concern that before the Qanun Jinayat was formally adopted only heteronormative adultery was against the law: 'So far there are only rules for male and female couples. Whereas for same-sex couples, both male and female, there is nothing. Follow-up action is needed' (Serambi Indonesia 2013). Three years later, a local politician, Farid Nyak Umar - chair of Committee D of the Municipal People's Assembly in Banda Aceh (Ketua Komisi D DPRK Banda Aceh) - claimed in an interview that 'LGBT has been present in Aceh since 2007 under the guise of [tsunami] victim assistance and human rights activities', adding that 'the existence of LGBT threatens the younger generation in Aceh, because this virus brings doom from Allah SWT and causes diseases for which, to date, there is no cure' (Serambi Indonesia 2016c). Furthermore, this type of news and information on the existence of LGBTI - such as care provision for HIV/AIDS - created new forms of fear and vulnerability; organisations that provided grassroots-level support for HIV positives or general awareness on HIV/AIDS were now increasingly becoming a source of surveillance. The people whose names were part of event participation lists or who were social and economic welfare beneficiaries consequently became the target of intelligence and potential violence and harassment.

Finally, HTI, which had, over the years, expanded its grassroots mobilisation and advocacy in Aceh (see Chapter 2), launched an anti-LGBTI campaign in 2016 as part of its overall Facebook campaign 'Aceh for the khalifat', its opposition summarised in seven points by the head of the regional HTI Aceh, Ustazah Rifqiyya Abdillah: 
1. LGBT is very dangerous because: it is the source and cause of transmission and therefore the spread of sexual diseases and sexual crimes; it is a tool for the genocide of human populations; it destroys society's order; it is contrary to human nature; it is forbidden by smart Islamic Muslims.

2. LGBT is the rotten fruit of a secular system. This system has given birth to such religious understanding that has taken refuge under the umbrella of human rights.

3. In the secular system, human beings are free to do anything to fulfil their physical desires, including sexual desires.

4. Therefore, rejecting LGBT must include the removal of its source and cause, namely, the secular system. Remove the secular system, the source of LBGT's birth.

5. LGBT can only be destroyed in the Islamic Khalifat, because Islam strictly prohibits, forbids and imposes strict sanctions on LGBT people.

6. The LGBT case is a symptom in Aceh, the autonomous region of Islamic Sharia. People of Aceh must jointly reject and eradicate LGBT \#Islamlaranglgbt

7. The only way is to perfect the application of Sharia in the Khalifat. Acehnese Muslims reject LBGT!!!!

Facebook group Aceh untuk Khilafah, 20 February 2016, site closed

The campaign proclamation focuses on the inherent impossibility of the equanimous coexistence of Islamic piety and non-heteronormal sexualness, thereby contracting lived experiences within the Indonesian archipelago (Boellstorff 2005a; Thajib 2017). The latter combination is, in fact, portrayed as a security threat to the societal order, and the suggested remedy is a return to the Islamist state and abandonment of secular state formation; thus, it can be seen as an active stance on the demand for decolonising the state. Curiously, this Acehspecific campaign pre-dated the national outcry against LGBTI rights and its community in Indonesia. It included several online interviews and the production of memes to be shared in social media; it was later continued through 'talk show' tours to campuses, such as the Islamic State University Ar-Raniry in Banda Aceh, with titles like, 'Understanding the risks of LGBT from the point of view of Islam, health and human rights' or 'LGBT love or disaster', which were led by student group leaders; there were also theatrical sessions where students role-played 'gays', 'lesbians,' 'boy/girlfriends' and 'HIV'. A specific social media campaign targeted the UN as a source of funding for LGBTI issues and organisations. Later, the acronym LGBT/I was changed into L68T so as to make searches and algorithms selective. In 2018, when a case of transgender arrest and police torture was discussed in local, national and international news, the HTI Aceh organised a demonstration in front of the Baiturrahman Grand Mosque - leading to the flight of several individuals belonging to the queer 
community. When the Indonesian court announced in 2017 that HTI was unconstitutional, its activities went underground and groups ceased to exist or changed their names. As of February 2019, the Supreme Court of Indonesia has rejected the appeal by HTI to overturn the central government's decision to ban the group in 2017.

As discussed in Chapter 5, the governance of pious bodies is extended from the government and law enforcement authorities to academic knowledge production. The 7th International Conference on Aceh and Indian Ocean Studies in August 2018 attracted a good number of participants from Aceh, the Indonesian archipelago, the South East Asian region and beyond. At one panel, 'Gender and social life in contemporary Indonesia', a paper was presented with the title 'Anticipatory efforts of lesbian, gay, bisexual and transgender (LGBT) community behaviour in Indonesia', by authors Muhibbuthabry and Sullaiman from the Islamic State University Ar-Raniry - one of the local organisers of the conference. The presentation focused on conveying the message that LGBTI is 'perverted behaviour which is not in accordance with the culture and religion adopted by the Indonesian people'; it quoted 'statistics' on LGBTI-identified people in Bandung and Medan, claiming the group consisted mainly of high-school and graduate students. The number of LGBTI in the city of Banda Aceh was said to be 500 - a figure that was challenged by an audience that included allies, although these tried to remain as neutral as possible. The conclusion of the study, which had included interviews with religious leaders and religious government officials, was that the former have an important role to play in preventing or anticipating LGBTI behaviour. Successful measures include information campaigns on the dangers of LGBTI, guidance for educators and positive alternative role models offered to the target populations.

\subsection{Precarious Queer Virtuality}

The Coaching to be strong transman video focuses on the experiences of a Banda Acehnese transman, and his struggles and ways of survival as a practising Muslim. How periods of displacement and taking refuge elsewhere in Indonesia never offer a long-term solution given commitments to one's family and parents and feelings of being at home despite the insecurities involved - only available for offline screenings.

$R:$ transman Raiz

$M$ : Marjaana, researcher

S: Seija, documentarist

(Chat was originally a combination of English and informal Indonesian, for the purpose of this section translated into English) 


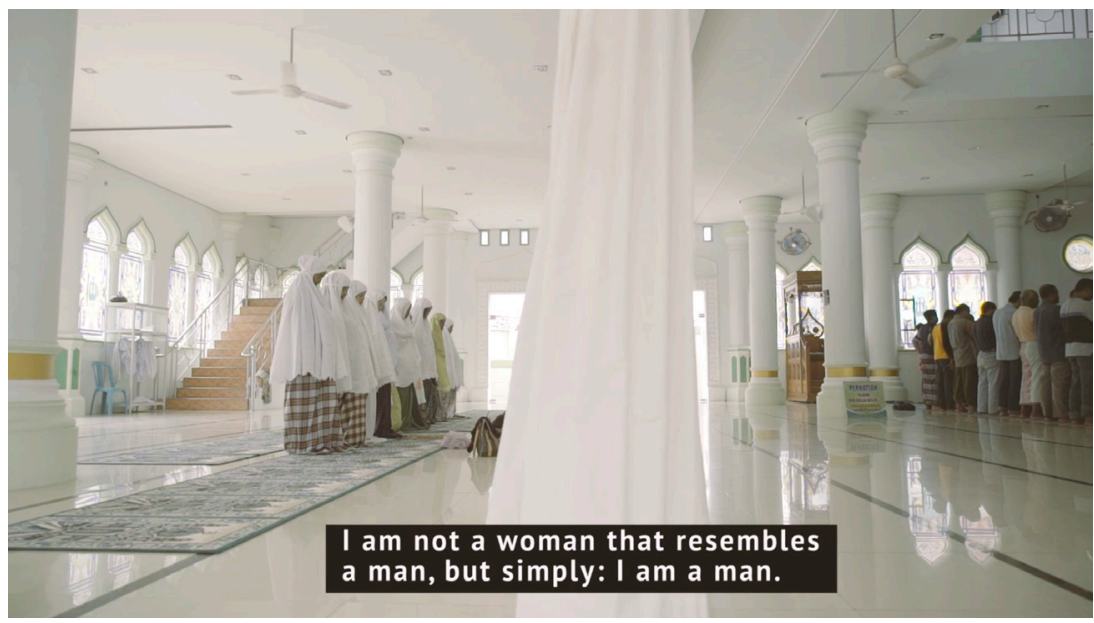

Video 13: Coaching to be strong transman (05:59).

Source: Scraps of Hope.

To watch this video, scan the QR code with your mobile device or visit DOI: https://doi.org/10.33134/pro-et-contra-1-video-13

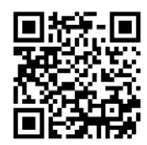

[Changing from Facebook messenger to WhatsApp]

\section{October 2015}

M: Hello, new start

$R$ : halloo

\section{October 2015}

M: Hai, how are you? The news of the arrest yesterday has already reached the international media. How is the situation now? Safe?

\section{October 2015}

$S$ : Hi! Have you had any thoughts about the video =)? I found an example of a technique (Image 10) we could use in the video to make people to look so that they cannot be pointed to any persons especially. Like this: How do you like it?

$R:$ I like it Seija. 


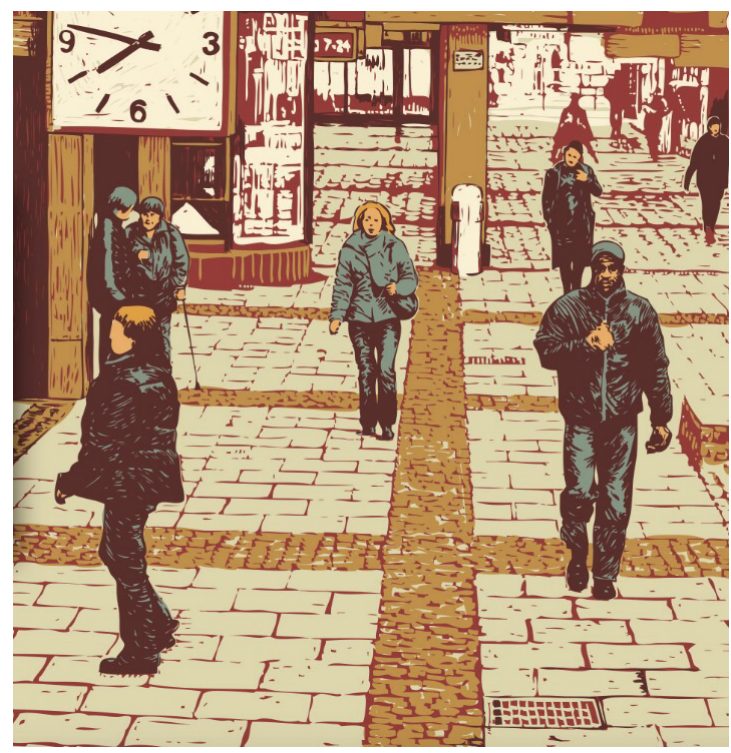

Image 10: Suggested video effect for Coaching to be strong transman video. Source: Seija Hirstiö.

\section{October 2015}

$R$ : Marjana [sic] n seija [sic]. I will leave aceh for 3 weeks Marjana [sic] my photograph is already with the Sharia police And they are now searching for me.

I will escape tomorrow to Jakarta.

[WA announcement: the new phone number of $\mathrm{R}$ is now $+62-\mathrm{xxxx}$ ]

\section{October 2015}

S: Hi Raiz! You ok?

Found safety for a while?

$R$ : Hi seija n marjana [sic], I'm okay now

$M$ : Hi, good to hear!

[Film shooting and research visit to Aceh for 60 days, 28 November 2015-27 January 2016]

[WA announcement: the new phone number of R is +62-yyyy] 


\section{February 2016}

M: Hi R, are you ok? The news from all over Indonesia is so sad ...

$R$ : I am not ok mar

[attaches photos showing calls to crack down on LGBTIs in Yogyakarta and Banda Aceh]

M: Are you in a safe place? I noticed you changed your number.

Just a few days before the formal enforcement of the Islamic criminal law in October 2015, the local and international media reported the first arrest and detention of 'a hugging lesbian couple' by the Shari'a Police. When its legality was questioned by local human rights activists, the police justified the arrest using the local regulation on Moderate Muslim dress. When I interviewed Raiz in December while we were shooting the film, I realised that this arrest had in fact involved a femme female and a transman. This incident, as the above WA chat illustrates, pushed Raiz into a totally new form of vulnerability, and he took refuge outside of Aceh for three weeks. These new forms of instability and turbulence materialise as short message exchanges even now as I am writing this chapter.

Yet, what became evident in our discussions of the October arrests later in December was that, instead of reading the arrested queer bodies - friends of Raiz - through the illegitimate heteronormative intimacy frame of zina, the local police specifically aimed at showcasing, both locally and knowing it would spread quickly internationally, their successful arrest of a 'lesbian couple'. This arrest and its media coverage can be read as a public warning for queers in Aceh, but also as a communication to outsiders. The Shari'a Police are known to have direct contact with print/online media in Aceh and the media usually knows when to follow them for juicy arrest headlines. Yet, the police, the local media and human rights organisations responding to the arrest had missed the point of transgender identity. Had the police read the couple 'correctly', they could have used the local regulation that prohibits all intimate proximity between the opposite sexes outside marriage (khalwat), and would not have needed to seek the offence of 'improper Muslim dress', or wait for the new Islamic criminal law to come into effect. This raises the question of unintelligibility. With a heteronormative reading, they are seen as lesbian tomboys, and thus they become vulnerable for police and legal action. As Raiz reads the Quran in the short film, he denies transgressing the boundary between a man and a woman (which is forbidden and punishable), because he truly is a man.

One big part of my ethnography consists of chats and screen captures of photos, discussions and links. It was common, especially with the trans community, for their profiles over the period of four years to undergo major changes, from deactivation to change of name to the creation of parallel social media identities with multiple co-existing names. In retrospect, the newly emergent LGBTI 
mobilisation also resulted in a vibrant social media presence, creating a positive atmosphere of coming out among the trusted. ${ }^{21}$ It also enabled the tomboy and transman community, in particular, which had limited possibilities to gather in public spaces, to start sharing their social life and belonging. For some of my research informants it meant a place to arrange encounters with customers for those who were part of the online circuit of Banda Acehnese sex work that was increasingly chased online from hotels and beauty salons.

However, although Facebook offered an assumed safe space for virtual queer communities seven to eight years ago in Aceh, over the past few years, and particularly in the months after the enforcement of the Islamic criminal law, it has created a new source of vulnerability for them. On 24 February 2016, the municipal government organised a strategic meeting with the Acehnese Middle East student alumni to discuss and find solutions for the LGBTI problem in Banda Aceh. The municipal government also uses such events to invite online media to ensure maximum publicity; using photographs that had been taken from Facebook, the Queer NGO (pseudonym, as mentioned above) was identified as a safe haven for LGBTIs and it became the target of increased surveillance. The staff went into hiding and later took refuge in Jakarta; all modelling school activities were cancelled and individual models were banned from participating in any local modelling/fashion events in the school's name.

In 2018, the Queer NGO's Facebook page only contained food advertisements, with some of the earlier model course and talent competition advertisements in Medan left in place for public viewing. It was with the same basic Facebook 'grassroots surveillance' techniques (when surveillance is undertaken by users, rather than relying on the big data available through other, more technical means) that the student alumni reported on the existence of the LGBT community in Banda Aceh, estimating it to consist of roughly 500 individuals. These, in fact, were the same techniques I initially used in 2012 when I wanted to get to know the LGBT community and the street punks. So, although Facebook seemed to offer a safe space between the avatar and the person's real identity, the networks (schools, groups) were the key. Thus, despite the fact that Raiz carefully draws a line between online and offline to negotiate his visibility (see also Gray 2009, 17), details of his high school (461 members), university (553 members) and friend networks were easily accessible for those with whom he had become friends. It is through the routines of everyday life that the social media applications become part of what makes it impossible to draw a simple distinction between offline and online, controlled or uncontrollable reality (Sonia Livingstone 2008, 393-394 quoted in Gray 2009, 17).

I woke up on 26 February to read the next chat from Raiz. He confirms he has changed his phone number and attaches a photo that is a screen capture from a recent online news item. After some five minutes of googling I draw quick conclusions: essentially, it is a report of a meeting the day before between the municipal government, the mayor of Banda Aceh and the Acehnese Middle East student alumni to discuss the urgent need to control the LGBT 
phenomenon in Banda Aceh. The news includes one photo where pictures from a fashion show organised by LGBT-run modelling company, Modelling Agency, are shown on a large screen at the municipality government meeting hall. The text under the photo claims that the 'LGBT mission' was brought to Aceh after the tsunami by the Dutch NGO HIVOS, and that the first organisation, Queer NGO, was formed in 2007 and is known to be dominated by gays and transwomen (waria). The news item also identifies and names other LGBT organisations, such as Modelling Agency, saying that they operate secretively and also that they organised a Homosexuality Day in 2010 at a four-star hotel in town categorised by the local media as one of the key locations for breaking Sharia principles (the ban on alcohol, khalwat).

Thinking about the safety of all those people I know who are affiliated with the named organisations, I google 'Queer NGO' and 'LGBT(I)' on my computer and find that, after a couple of pages of English media links, open access publications appear. I speak to a number of people who are part of this publication chain - as authors, but also as interviewees, through references, through quotes and via the names used by international media outlets. We chat, make phone calls and check on the safety of the individuals whose names might have been compromised. I go through all my publications to double check that no names are mentioned and I contact my publishers to ask if the preview of my book, without my consent, is a violation of the contract. They never respond. Facebook goes silent. People disappear. Names are changed. Raiz reappears a few days later. He has decided not to take refuge. He says he wants to stay, otherwise there would be no one protecting the community. Plus, he knows from previous experience that he has to return to survive economically and take care of his family, being the only child.

Since then, the community of activists has been zig-zagging between affects, locations, safety procedures and strategies of which the negotiation of safety procedures with researchers, journalists, film-makers, human rights organisations and transnational alliances forms an essential part of becoming, without harm. The next section discusses one attempt to have a dialogue with dignity with local and international human rights defenders.

\subsection{Negotiating Dignity and Safety with Local and Global Human Rights Defenders}

As the tongue-in-cheek video transcript discussed at the beginning of this chapter illustrates, the international diplomacy of the 'rightminded and wellmeaning states' has increasingly offered the framework of supporting LGBTI rights as a response to the criminalisation of same-sex intimacies and gender plurality, particularly through the mechanisms of peace-building and legal reconstruction. The role of an eager and enthusiastic, newly appointed ambassador reprises that of a Nordic white feminist 'do-gooder' who simultaneously 
celebrates the world's liberal and democratic progression, while ignoring the fact that global security for queers and 'for everyone' can also include contradictory policies on the arms trade, the global political economy and the closure of fortress Europe to racialised migrants seeking better lives.

This ethnography has had limited access to formal diplomatic circles; consequently, instead of examining the views of feminist diplomacy, this section focuses on a dialogue process established by one international human rights organisation in Banda Aceh, right after the 7th International Conference on Aceh and Indian Ocean Studies discussed earlier in this chapter. The organisers had divided their consultation process into two sections: the first, a dialogue with 'LGBTI-sensitive' local human rights defenders and potential allies; and the second with a group of people representing different communities in Aceh. The ally dialogue explored safe ways of supporting the community and its individuals, sharing strategies to protect people being used by human rights defenders in Aceh and elsewhere - strategies which had also been used to advocate against the human rights violations experienced and reported in Aceh during the armed conflict, especially during the period 1988-1998, known as DOM (Dearah Operasi Militer, Military Operation Area). It was the first time I witnessed a decades-long activist model being drawn on the whiteboard for the use of LGBTI ally strategy development.

For the safety of the community and the allies, no details of this discussion, or the discussion with community representatives, will be repeated here. However, the meetings clearly illustrated that the end result of the function of power and the machinery of violence is that what may initially appear to be a gesture of solidarity initiated from the outside towards a marginalised and oppressed community may in fact become a vehicle of further visibility, thereby extending the target of violence and vulnerability. The second meeting, in particular, included detailed descriptions of processes led by media, human rights organisations, researchers and film-makers that, instead of alleviating the community's main concerns - personal and family member safety and sustained livelihoods, have created new forms of fear, a withdrawal from solidarity and sharing, and the use of third parties when participating in events, so as to remain safely distant from the debates and locations where such consultations take place.

\subsection{From Queering to Dig, Dag, Dug - Feeling of a Heartbeat}

This chapter has produced an ethnographic description of the governmentality, violence and surveillance experienced by non-heteronormative sexualities, and the life-worlds of those who do not conform to the gender binary established by Aceh's current legal and moral-political framework. It began by exploring the ways in which such topics are currently discussed in international relations, increasingly as 'queer peace-building', while paying particular attention 
to the need to decolonise and decentre Western notions of sexuality and gender forms. However, it has also illustrated that local notions of sexualness are always, voluntarily or involuntarily, part of a number of transnational spheres of moral and sexual politics, that of the liberal and human-rights based 'LGBTI identity politics', but also those countering such measures in the name of transnational piety and Islamic identity politics, or even counter-terrorism. Many grey areas remain invisible if the focus is solely on threats or feelings of fear and vulnerability. This chapter has aimed to illustrate how queerness in urban Aceh temporalities, in the words of one transman, have the feel of a heartbeat: dig, dag, dug. Meanwhile, the simultaneously shrinking public sphere has generated a number of ways of creating alternative life-worlds, from cyber space and social media to cultural praxis and forms of intimacy and care. Many of these cannot, however, be addressed here, in order to respect the desire of those involved to remain invisible and live a life of dignity. 



\section{CHAPTER 7}

\section{The Political Economy of the PET Bottle}

\subsection{In Search of Piety through Bottled Water}

An upper-middle-class house: a man is reading a lifestyle magazine in an armchair, a small boy is at the water dispenser hoping to pour a glass of water for him; behind them, in the kitchen section of the room, is a woman holding a book and watching the boy at the water dispenser. The boy presses the button.

Boy: Father, the water is finished! [In the background, the woman makes a sandwich in an open-space kitchen-cum-living room; the man gets up from the armchair.]

Father: Owh. [He opens a plastic bag containing a new water bottle.]

Boy: Let me help you change the bottle!

Father: No need, because we are now using the new Cleo gallon water bottle.

[He opens the plastic revealing the gallon bottle. Cut to the bottle with the text 'gallon bottle with a handle, first in Indonesia'.]

Narrator: New gallon water container with a handle, the first in Indonesia. Contains 19 litres of water. The body is BPA free, without colouring.

[The man carries the water bottle home, placing the bottle into the dispenser, while the woman and the boy gather around the dispenser and the boy dispenses a glass of water.]

Citra Nusa Advertising 2014

Zubaidah: How long have you worked here?

Dedi: Almost one year, in December about 10 months ... At first I wasn't doubtful, although it is disgusting, dirt, insects, smells. I said it is a challenge that has to be tried, [that I am] being tested by God. If I am being tested here, maybe all this will [mean] good fortune for me later ... As long as I do not complain. If one complains, good fortune is harder to 
reach ... So, up until now I have not yet [found good fortune], but [am] just being happy. Happy as we say.

Extract from the Don't be angry video

As the previous chapters have illustrated, notions of building back better in Aceh have been reflected on, acted on and sometimes resisted in a quest for improved lives, in mourning for lost ones and in creating a sense of the gendered, and gendering, of the everyday. Ten years after the Indian Ocean earthquake and the tsunami, it is said that new water normalcy has been restored (for analysis of bottled water in post-disaster relief contexts in Mexico and the US, see Pacheco-Vega 2019a). As the examples above illustrate (including Image 11), this includes the normalisation of a packaged or bottled water paradigm, which, along with its family consumption and economic well-being ideals, goes

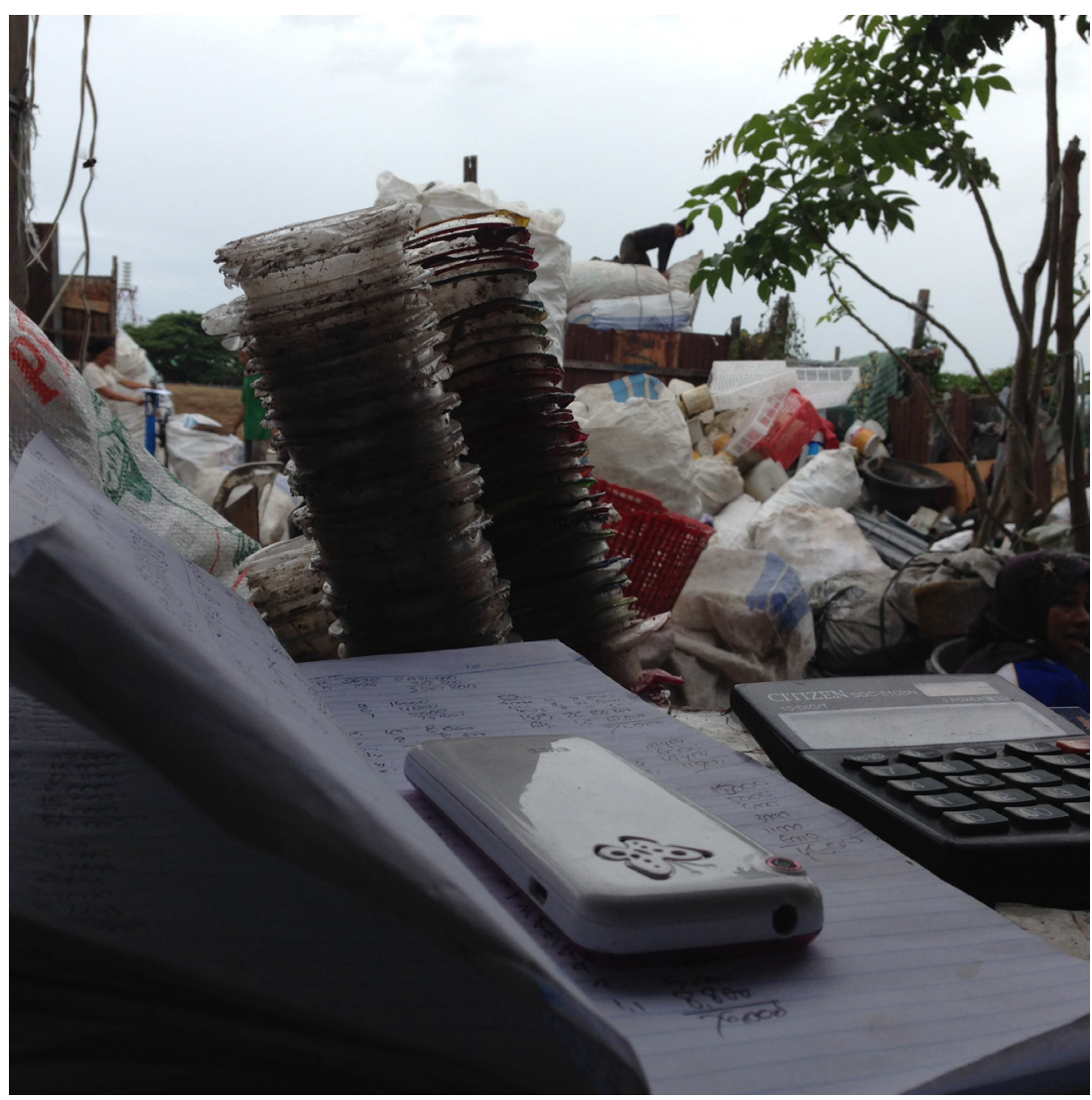

Image 11: Plastic cup recycling in Banda Aceh.

Source: Marjaana Jauhola. 
hand in hand with the shadow economy of PET (polyethylene terephthalate) bottled water, described by Dedi, a bottle recycler in Banda Aceh. In fact, water researchers suggest that post-disaster relief measures, framed as providing disaster-affected communities with access to water through temporary bottled solutions, promote the longer-term creation of inequalities through privatisation, marketisation, commodification and cumulative dispossession (Pacheco-Vega 2019a, 118-119). Yet, as Farhana Sultana has put it, 'water ... seeps across all boundaries and all aspects of life, as it is simultaneously social, economic, political, institutional, cultural, spiritual and ecological' (Sultana 2018, 484). Further:

Water is essentially about power - the power to decide, control, allocate, manage - thereby affecting people's lives. This is intersectionally experienced by gender, class, race, and other axes of social difference, therefore affecting different groups of people in varied ways. Isolating a specific water issue thus often misses out on broader connections that tie peoples, places, policies and ecologies in far-flung places.

Sultana 2018, 485

How has this rapid change towards bottled water consumption and recycling happened in Banda Aceh? Throughout the affected area, the Indian Ocean earthquake and the tsunami had rendered most pre-tsunami water supplies completely unusable due to the destruction of piped-in water infrastructure and groundwater pumps, while saline water damaged wells and surface sources (Clasen and Smith 2005). Globally, to respond to the water insecurity, there is a documented shift to bottled water, which Raul Pacheco-Vega (2019b) suggests is a direct result of three things: weak regulatory water regimes, the inability of governments (locally, regionally, nationally) to provide a steady supply of water and accelerating urbanisation.

Based on a survey conducted in Aceh in 2008, bottled water had become the main source of drinking water in the surveyed neighbourhoods of Banda Aceh, and respondents preferred branded products, although they were clearly more expensive than locally produced, refilled bottles (Song et al. 2009, 235). This is perhaps not surprising, as globally bottled water is the second most consumed beverage after soft drinks (Jaffee and Newman 2013, 1-2), following the pattern of the 'accumulation of dispossession' in which the management and manipulation of crises or disasters provide new markets and opportunities for the commodification of formerly public or non-market goods (Harvey 2003, quoted in Jaffee and Newman 2013, 5). In 2010-2011, 23.9\% of the bottled water globally was consumed in Indonesia (Pacheco-Vega 2015, 231). Although introduced as early as 1901 by a Dutch businessman (Prasetiawan et al. 2017, 3), the big boom in bottled water markets started in 1973 when the Aqua brand was introduced to the market, and it is claimed that currently over 700 companies provide over 2,000 brands (ibid., 2). Consumption levels are high, water contributing to 
up to $85.1 \%$ of all beverage sales, and 'aqua' is a word commonly used for all bottled water, illustrating the strength of the brand name and the share of the markets it claims (46.7\%) (ibid.). Yet, Prasetiawan and colleagues (2017) argue that instead of merely succumbing to the global 'hype' of bottled water, in the Indonesian context in general it is not a question of choice, but, rather, that it is the only source of hydration. Furthermore, analysis of the quality of water in Indonesia suggests the prevalence of contamination by faecal coliform and that water is, in fact, unsafe unless it is processed (Komarulzaman et al. 2014, 2 ). As this chapter illustrates, however, the reconstruction of the city of Banda Aceh has its own trajectory in which the flow of bottled water became normalised and embedded in middle-class aspirations, part of the economy of plastic recycling and also a product of consumers' mistrust of boiled water, despite the city's administration managing to provide tap water, at least theoretically, for $85 \%$ of its citizens. ${ }^{1}$

This chapter follows the journey of a plastic bottle from glossy advertisements, such as the Clio, to neighbourhood kiosks and supermarkets, to consumers at state bureaucracies, university campuses and homes, and onto recycling sites and waste management. What cultural changes have the tsunami and the increased commodification of water brought with them, and in what ways does bottled water connect the city's various social and economic classes to one another? How are bottled water and recycled cups part of the biopolitical 'regimes of living' (Hawkins et al. 2015, 355/5473, quoting Collier and Lakoff 2005)? How do such arrangements shift norms, our thinking and cultural and material practices in general? What differentiates the context of post-disaster provision of drinkable water from one purely of convenience, leisure and lifestyle choice (ibid., 1699/5473), and what are the changes in Acehnese water cultures or political economies of water (ibid., 1171/5473)?

Earlier research on the commodification of post-disaster aid in Sri Lanka has suggested that, despite good intentions, aid and its aftermath reconfigures patron-clientelist relationships and fuels the political economy that drove social conflict and discontent in the pre-disaster years (Korf et al. 2010). In the case of bottled water, the connections and relationships are intimately linked to the environmental costs of plastic, but also to the aspirations of the lowermiddle classes and urban poor for better lives through micro entrepreneurialism via recycling. Istvan Meszaros has suggested that a capitalist economy 'cannot separate advance from destruction, nor progress from waste, however catastrophic the results' (quoted in Opel 1999, 70). Advancement and progress was apparent in the recovery of the tsunami-struck city of Banda Aceh and in the growth of aspirational middle classes. Nonetheless, the destruction and waste of bottled water increasingly pollutes the environment and leads to new kinds of water crises, attachment to global networks of plastic waste circulation and the political economy and ecology of recycling, ${ }^{2}$ despite also offering important new sources of livelihoods for the urban poor. 
This chapter begins by focusing on the effects of the tsunami disruption and reconstruction on the water supply. It then introduces a PET bottle-recycling centre in Banda Aceh and two people whose livelihoods are intimately connected to bottled water consumption and plastic cup waste. PET street-recycling is then investigated as a form of social rafting and economic buffering, and finally, the chapter gives an account of the commodification of water in an aspirational middle-class family, touching on alterations made to their reception room and reflections on a visit to a water park.

\subsection{History and Context}

Arriving in Banda Aceh for the first time in April 2006, over 16 months after the earthquake and the tsunami, gave me a first-hand lesson on the scarcity of water in the city. In Finland, my country of origin, the average daily use of drinkable water per person is 140 litres, yet the four months spent in an expatriate house in a wealthy part of Banda Aceh taught me to master taking a bath and washing my hair with roughly 4 litres of water. All drinking water was bottled. In 2006, when the Japan International Cooperation Agency (JICA) calculated the water needs of Banda Aceh citizens, it relied on the forecast that each member of the served population would consume more or less the same amount of water per day as an average person in Finland (139 litres in 2005). There was a major difference, however, as the served population in Banda Aceh was estimated at only $58 \%$ of the total population; when shared among those without water connections, the daily average usage was estimated to be 80 litres (Japan International Cooperation Agency et al. 2006).

In 2006, running out of water was normalcy for most Banda Acehnese residents as most of the people displaced by the tsunami lived in temporary barracks with limited water and sanitation facilities. The scarcity of household water was, as noted above, due largely to the fact that the tsunami had destroyed the water and sanitation infrastructure and the debris and salt water had contaminated wells along the coastline, including those of Banda Aceh (Gupta et al. 2007; Rahman et al. 2019, 404). Those who could afford it and had the infrastructure, including the international NGO with which I was associated, would order water-tank cars to fill their reservoirs; the contamination of wells and water-pipe lines also resulted in a dramatic increase in demand for bottled water (Air Minum Dalam Kemasan, AMDK). As with most commodities, this produced a chain of wholesale and retail traders, mostly from Northern Sumatra, but later joined by local bottled water companies and, importantly, small kiosks that provide refilled water bottles.

According to Banda Aceh statistics, by 2011, the municipal water infrastructure served $83.16 \%$ of the Banda Acehnese population, rising to $94.26 \%$ in 2014 (Badan Perencanaan Pembangunan Daerah Kota Banda Aceh 2016, 20; 
Rahman et al. 2019, 407). This is impressive when compared to the overall statistics for municipal water coverage in Indonesia: 10.2\% in 2015 (Prasetiawan et al. 2017, 2). Tsunami reconstruction efforts included the rebuilding of two water treatment plants on the outskirts of Banda Aceh, which became functional in 2006. For a number of reasons (technical, geographical and economic, as well as political violence), many residents did not have access to a safe water supply in pre-tsunami years (Song et al. 2009, 233); thus, attaining a service coverage of $94 \%$ was indeed a fulfilment of the promise to 'build back better'. Historically, Taman Sari, the landmark of middle-class free time and outdoor entertainment in the post-tsunami city, is also the location of a Dutch-built water tower, constructed in the 1880s, where one of the city's public water taps is still located; it once served the civilian and military population of Kutaradja with the water collected from the mountains (Banda Aceh Tourism 2015). Now restored as a historical tourism sight, the tower is located in the grounds of the former Sultanate Palace. During the colonial period, piped water mostly served the higher social classes - Europeans, colonial officers and local elites - whereas the rest of the population depended on wells and surface water for their domestic needs (Prasetiawan et al. 2017, 1).

A couple of years after the tsunami reconstruction, however, gossip and anecdotes had begun to contradict the post-tsunami water success story, specifically targeting the scarcity of potable water in the city through connections made with the selective implementation of Sharia law under the civilised city (kota madani) slogan. Stories were told of households going days without running water, and public buildings mandated to provide space for prayers and Wuduh ritual cleansing having failed to fulfil these basic requirements. Meanwhile, law-enforcement mechanisms focused on morality punishments for, among other things, inappropriate Muslim clothing, and illegitimate intimate proximity and sexual relationships (Afif 2015). The question of water quality became one of the topics hotly debated in the 2017 mayoral elections, and demonstrations again took place in late 2018 in front of the municipality office, Balai Kota (Nasir 2018). Surprisingly, when water users were surveyed, only $59.38 \%$ said they primarily used the municipality water infrastructure, while $37.56 \%$ used wells, $2.88 \%$ relied on deep ground-water pumps and $0.18 \%$ on commercial water-refilling kiosks, raising questions about both the quality and consistency of water availability, and the installed pipelines (Rahman et al. 2019, 407). In 2013 , based on customer billing. nearly $45 \%$ of the water supply was said to be lost from the pipelines (ibid., 408).

In 2014, water cups $(240 \mathrm{ml})$ in cafes and kiosks in Banda Aceh usually cost 1,000 Rp, 1.5-litre bottles cost 4,500 Rp and the retail price for 19-litre bottles was 20,000 Rp, but the prices ranged from more expensive brands (such as $\mathrm{Aqua}^{3}$ and $\mathrm{Cleo}^{4}$ ) to the cheaper local varieties, while a box of $48 \times 240 \mathrm{ml}$ water cups ranged between 11,000 Rp (229 Rp per cup) wholesale and 18,000 $\mathrm{Rp}$ (375 Rp) retail. Refilled water bottles had become a source of income for many as they provided a cheaper alternative to bottled water transported to 
Aceh from other parts of Indonesia, mostly from Northern Sumatra. Whereas a gallon (19 litres) of Aqua cost 20,000 Rp, a refilled gallon cost around 4,000 Rp (Song et al. 2009, 235). According to a small survey conducted in selected tsunami-affected neighbourhoods in Banda Aceh, residents were using up to $16 \%$ of their income to purchase water (Song et al. 2009). Compared to the public water supply, the price of both bottled water and refilled water is high, taking up to $20-25 \%$ of the surveyed people's income (ibid., 235).

A year after the tsunami, the UN Population Fund's report warned that the lack of access to clean water and sanitation facilities was a major concern for female populations living in temporary barracks and tents (UN Population Fund et al. 2005) and, in 2011, the lack of access to clean water was still identified by the Regional Body for Planning and Development (Badan Perencanaan Pembangunan Daerah, BAPPEDA) as a significant factor in increased poverty and the 'vicious cycle' in which the poorest pay the highest prices for clean water to third-party suppliers (Rahman et al. 2019, 409). Yet, one of the municipal government's tasks is to ensure the quality of drinking water. In 2014 and 2015, local media reported on cases where bottled and cupped water did not meet the criteria set for them, and a number of local water companies were closed and their products withdrawn from the market; in some instances, the water came from private wells, but also from the municipality's water pipes and wells. The label 'water scarce' is used to justify large-scale interventions in the distribution of water (Mehta 2007), yet scarcity is relational rather than absolute (Hawkins et al. 2015, 2130/5473). This chapter explores some of its trajectories, and the potential cultural, social and economic meanings entailed in bottled or cupped water.

The story of the plastic bottle or cup of water is not, however, only a retelling of the post-tsunami narrative or the emergence of PET water bottles in the 1970s. Rather, as the study conducted in the mid-1980s titled 'Plastic arrives at the village' (Siswayasa 1984, 17) suggests, the cultural and societal changes instigated by industrial products is a much longer one, stretching all the way back to the colonial period, and thus can be seen as a lengthy process of cultural, societal and economic change. The study, conducted in a rural village in Aceh Jaya, showed that plastic products, such as rice bags, woven mats, table clothes and plastic bags, had appeared in local markets in the late 1970s, predominantly produced in Sumatra, West Java, China and Jakarta (ibid., 26). In the mid-1980s, the most salient change was from bamboo utensils and water containers to plastic and aluminium (ibid., 58-59), while one of the most noticeable differences in the post-tsunami urban coffee shops has been the switch from shop-filtered water served in glasses to bottled water, often served in the individually packed, $240 \mathrm{ml}$ cups. Although bottled water had been introduced to Acehnese markets when Aqua was established in 1973, the sudden prevalence of bottled water in the aftermath of the tsunami, particularly the smaller water cups, is remarkable. Banda Aceh produces 180 tons of waste daily, of which plastic waste comprises $0.74 \%$, whereas the national average in 
Indonesia in 2016 for discarded PET bottles was 1\% (Drwiega and Septiono $2019,2)$. According to Nizar et al. $(2018,4)$, most of the city's waste is collected, transported and dumped in an open site at Gampong Jawa. From there, some of it is sorted for sale and recycling by officers and scavengers. The 2017 by-law adopted in Banda Aceh (Qanun 1/2017) makes provisions for the value-added re-processing of plastic waste, paper, cans, bottles and scrap metal. There is clearly an established market and profit to be made in recycling. ${ }^{5}$ Indonesia is the second largest exporter of plastic waste within the ASEAN region (20\% of the region's exports) (Drwiega and Septiono 2019, 3); until 2017, when China banned the import of plastic waste, Indonesia had an important role in exporting processed plastic to China, and since then, Indonesia's imports of plastic waste doubled from 2016 (ibid., 3, 28). The increase in plastic waste first skyrocketed in 2010 , rising by $12000 \%$ to 39.9 million tons, compared to the previous year's 3.1 tons (ibid., 28).

The authors of Plastic water: The social and material life of bottled water suggest that the emergence of PET bottles in the early 1970s has ultimately produced new social and economic relations, as well as meanings that have become part of changed water drinking practices (Hawkins et al. 2015). Indeed, 'bottled water has emerged as a political problem and a political object' (Braun and Whatmore 2010, quoted in Hawkins et al. 2015, 149/5473); this places a focus on how politics is assembled vis-à-vis bottled water (Hawkins et al. $2015,160 / 5473$ ), and how in the case of (post-disaster) markets in Asia, bottled consumables have become part of the 'fragmented water supply and waste infrastructure networks' (ibid., 283/5473). How is bottled water a response to middle-class post-disaster supply, and recycling a new form of economisation? What are the potential 'shadow' political effects of it and how does dispossession emerge as an intimate part of such consumption?

Let us return briefly to the two most well-known bottled water brands and the representations and symbolic exchange value and social meaning they offer (Opel 1999, 70). Whereas the Cleo TV commercial advertises the most recent innovation - the gallon with a handle - through idealised images of an upper-middle-class heteronormative family, another other Cleo advertisement depicts a nuclear family flying a kite in a park which is a merger of forest, mountains and seashore. Although both clearly appeal to the ideals of the prosperous nuclear family (see, e.g., Jauhola 2013), what is most remarkable is that bottled water brands seem to focus on purity (Opel 1999), health and the virtuous body (see the connections to da'wa in Chapters 2 and 3).

For example, Cleo advertisements focus on sports events (see also Jaffee and Newman 2013, 10), the national heroine R. A. Kartini along with the slogan, 'time to be clever' (saatnya jadi pinter), and showing the bottle in the contexts of studying, office meetings and so on. Aqua advertisements, on the other hand, focus on clean nature or everyday heroes who, 'just like water' (bagaikan air) 'embody water's symbolic qualities', such as 'purity, generosity, and 
transparency' (Campaign Brief Asia 2015). The company provides examples of these attributes in its video/TV advertisements, which comprise a series of social experiments regarding how people react to certain scenarios: a pregnant woman standing at a busy bus stop where all available seats are taken or carrying a heavy bag up a flight of stairs; someone dropping their wallet on a busy street in central Jakarta. The videos end with the slogan: 'the good continues to flow, just like water' (Sehat AQUA 2015).

Although markets are dominated by these big multinational bottled water companies, locally produced bottled water has been, and is still seen to be, an important element for investment and economic development, but also as entangled with the production of Islamic Aceh, both through the idea of piety, as discussed earlier, and that of producing local halal products. By consuming locally produced bottled water, the local government and Department of Industry and Trade suggest that Acehnese bottled water consumers are making a more 'ethical' (Pacheco-Vega 2019a) choice that directly benefits the local markets, '[b]ecause, with mineral water shopping alone, tens of billions ... from Aceh annually flows to Java and North Sumatra' (Serambi Indonesia 2019c). The local newspaper further equates the consumption of bottled water with a 'love of local products', thus creating affect-driven consumerism that is said to make the Acehnese economy thrive (ibid.).

\subsection{Bottle Recycling Centre}

Today I've cycled along the Aceh river bank road towards the sea and the Zero Point monument of Banda Aceh (formerly known as Kota Radja). ${ }^{6}$ I stopped to watch a fishing boat unload its catch then continued cycling towards the sea. After the neighbourhoods of Keudah and Java, the scenery changes: wasteland, recycling centres for plastic, carbon boards and so on behind metal fences. After a small bridge there is an army military post, the entrance to the municipal landfill site, a waste water management site with a sign that it was built with the support of UNICEF, the monument, a small shop and the sea shore. This is the main site of waste management in the city. Heavily laden yellow waste trucks go inside the landfill area and return empty.

Fieldwork notes 2014

Waste collection trucks are a familiar sight in the post-tsunami reconstrucion city, collecting neighbourhood household waste from the designated waste bins.

As part of restoring urban water access, post-tsunami reconstruction efforts also emphasised the importance of restoring water management infrastructure and investing in campaigning for effective waste management in urban neighbourhoods. Consequently, waste bins (Image 12) and regular municipal waste 


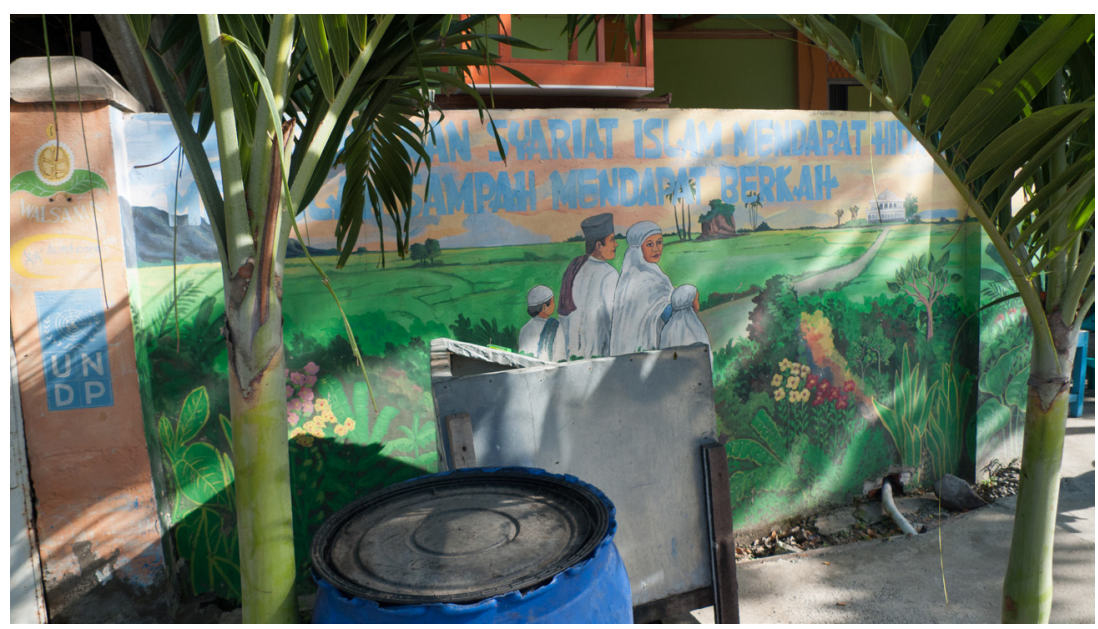

Image 12: The implementation of Shari'a Islam results in guidance, managing waste and ultimate blessing.

Source: Marjaana Jauhola.

collection have become normalised in Banda Aceh. The painted images on the waste bins present ideas of good and pious Muslimhood, and thus are part of the holistic da'wa mission of full implementation of Shari'a principles, or urban social engineering, in the city (Feener 2013). As I have suggested elsewhere (Jauhola 2013), waste bin aesthetics thus participate in the construction of gendered identities and are also intimately connected to religiosity praxis and good urban citizen conduct. They can, therefore, be seen as a continuation of colonial processes of transforming urban spaces into public areas where 'common ideals of hygiene and aesthetic order are expressed' (Chakrabarty 2002, 66). Further, following Mary Douglas, Chakrabarty suggests that 'dirt can go only to a place that is designated as outside' (ibid., 69). Understood in this way, the role of the 'non-European' in the global trade of waste and consumption of plastic should not be located outside of the modern; rather, global waste or litter illuminates a system of differently created responsibilities, orders and global socio-material relations (Hawkins et al. 2015, 2541).

Waste bins, along with municipal waste collection trucks, waste collectors (both municipal and private) and scavengers, connect the post-disaster ideals of urban citizenship, consumption and waste management/recycling practices (for analysis of the connections between modernity and garbage, see Chakrabarty 2002) to the recycling centre and landfill sites in the city as both a value chain and labouring to fulfil the ideals. Disposability relies on these intermediaries, who also supply the physical, social and economic distance and demarcation between the moment of disposal and flow of waste within the city, a space between waste management and consumption (Hawkins et al. 2015, 2372, 2384/5473). 
The tsunami impacted nearly $60 \%$ of the city and the amount of debris and waste generated from damaged housing infrastructure - wood, tiling and mixed materials - was calculated to be approximately $853,930 \mathrm{~m}^{3}$ (Srinivas and Helmy 2015, 194); overall waste was estimated to be $1,742,714 \mathrm{~m}^{3}$ (ibid., 195). The main landfill site in Gampong Jawa, which was originally opened in 1994 with 12 ha of space, was chosen as a final disposal area for the tsunami waste. In 2006, the municipal government purchased a further 9 ha of unused fish ponds and the reconstructed site was opened in 2009 (Mirzayanto and Gressando 2013). To start with, debris clearance was one way to support survival, yet displaced populations were employed by humanitarian organisations in different kinds of cash-for-work initiatives in the early months after the tsunami. Similarly, reconstruction projects were geared towards recycling debris materials into furniture (Srinivas and Helmy 2015, 197). Efforts to introduce municipal waste collection bins failed initially and they were left unemptied, as the focus was initially on debris. The tsunami waves moved the waste from the municipal landfill waste management site in Gampong Jawa into the ocean where it had a serious impact on marine ecosystems and, therefore, the livelihoods that depended on them (ibid., 198).

After visiting the beach and watching the shoreline net fishing, I decide to walk into one of the recycling centres on the Jalan Teungku di Anjong. A truck is being loaded with huge plastic bags containing recycled plastic. The young female manager calls me in and says, 'Those women over there are calling you.' I walk past the measurement equipment and mountains of piled plastic and I see four women squatting at the back of the centre's premises, cleaning water bottles and cups for recycling.

Fieldwork notes 2014

As discussed elsewhere (Hawkins et al. 2015), the manual labour of cleaning and turning waste plastic into 'raw material' is often the work of women and the urban poor. The collectors and the cleaners who handle the waste directly have the lowest position in the social and economic hierarchies of the recycling business. However, they enter the hierarchy as economic subjects, and consider it an essential livelihood - even though touching the waste, and working with strong odours and environmentally hazardous materials, makes them vulnerable health-wise and also stigmatised. In the political economy of post-tsunami reconstruction, and post-conflict legal frameworks, these jobs are occupied by members of a number of marginalised communities, and are considered an important economic resource in their daily lives.

It is through their labour that used and discarded water bottles and cups have material capacities and effects (Hawkins et al. 2015, 2353/5473). These are the hands and the bodies that form the heterogeneous infrastructure of waste management that makes bottled water market operations possible (ibid., 2372/5473). Hawkins and colleagues (ibid., 2361-2372) refer to this part of 
recycling as its 'shadow reality'. Approaching the topic ethnographically, however, allows this positionality to be questioned, recentring the labouring bodies and bringing their realities into focus, while acknowledging that even bottles can be endowed with agency and demands in the process of recycling (ibid., 2462/5473). The fact that emptied and discarded bottles provide opportunities for newly emerging networks, subjectivities and experienced everydays should not be analysed separately from the visions of life they offer labouring subjects, allowing them to imagine better futures or find solutions in their everyday lives. These are intimately connected to recycling's socio-spatiality, which is 'constituted through practices and multidirectional relations' (ibid., 2428/5473) that are intimately linked to the city's recovery, but also to practices generated by poverty or informal entrepreneurialism' (ibid., 2507/5473).

Hierarchies created among the different roles and functions indicate that those who are in direct contact with the waste experience stigma within their communities. Those on the lower rungs of the ladder live precariously, and such everyday realities are part of the livelihood options for the urban poor and newcomers (see also Hawkins et al. 2015, 2553/5473). The recycling centres I visited in 2014 and 2015 are temporary storage and cleaning locations for the cups and bottles, where they arrive from junk collectors within the city and from the landfill site. The material complexity and diversity mean that these centres specialise in cups, bottles or other plastic materials, such as food packaging or bags, as they cannot all be processed or recycled at one site (ibid., 2574, 2640/5473). This requires the economisation and specialisation of skills, but also a 'choreography' (ibid., 2640/5473) based on the high degree of separation of the different parts of PET plastic processing.

Women wear gloves on their left hands, while the right one holds a knife which they use to remove the lid from the water cup. Lids are thrown into a bag, the cup is straightened and piled together using a bottle holder. This place has been open for about a year, but these shops are located one after another along the street. Work starts at 8 am and after a lunch break they continue working until $6 \mathrm{pm}$. They are paid $1.500 \mathrm{Rp}$ per kilo (1.5 times what one water cup costs at a local coffee shop or kiosk), and on an average day they are able to process roughly $15 \mathrm{~kg}$, totalling $22,500 \mathrm{Rp}$ per day, ${ }^{7}$ which they say is not enough to maintain them.

Fieldwork notes 2014

Physical strength is needed, [you] need to stay in motion; if not, then I don't know about the results.

Interview December 2015

The main body of the cup is made of clear PET, which has higher resale value than the coloured lids and can be reused in the production of new 
PET, whereas the coloured plastic will become material for carpets or polar fleece (Hawkins et al. 2015, 2652-2664/5473). This work is mostly done by women and newcomers, but, in the case of the recycling centre visited in 2015, it also provided livelihoods for queer/non-gender confirmative people. Four women who met in 2014 are all migrants from different parts of the province. The stories of these women include periods of urban migration, divorce or struggles with mental issues. Yet, one of the women says her children, despite the high cost, aim for secondary school and private university education. In 2015 , while recording the life historical videos, we stop by one of the other recycling centres and have a chat with one of the workers and the manager. Their stories are useful in understanding the possibilities and challenges that such work entails.

Our introduction to the person cleaning the water cups, Dedi, has a 'queer' start. Zubaidah, who holds the microphone, approaches Dedi and addresses them using an assumed gendered greeting, which Dedi corrects. A brief moment of laughter follows, and a discussion of whether males can be manis or sweet, but for someone who has conducted research with the queers in the city, this is also an invitation to interpret the unfolding life history in certain ways.

We are told that both men and women can be sweet. Working in the recycling centre for about 10 months is regarded as good fortune, as it has meant a steady income, despite the fact that at first the dirt, smells, insects and health hazards that accompanied the work felt disgusting (jijik) and caused our interlocutor to hesitate when a friend introduced the place. 'It is a test from God', Dedi says, and it is likely that even men can be vulnerable and weak. Having survived the tsunami with their older brother has meant that they continue living together, although the brother has got married meanwhile. Before joining the recycling centre, they helped their sister-in-law in a sewing business, and before the tsunami worked as a shop assistant in a photocopy shop and baking cakes.

Fieldwork notes $2015^{8}$

The Don't be angry video tells a story of a bottle recycler, Dedi, his solutions to make ends meet, and his reactions to hate and discrimination.

Dedi continued by remarking that beauty meant beauty in the heart, as well as patience. Most important to them is that there is a job, although other people might hate them or be aggressive towards them:

Yes, what I mean is that I am searching for a livelihood, not enemies. But even in a job, if someone is not happy about me, I will remain content with that person. I do not want to fuss. Although they do not want to see me, and they look away when I meet them, I still greet them, because ... God is not happy with humans, because we humans should get together 


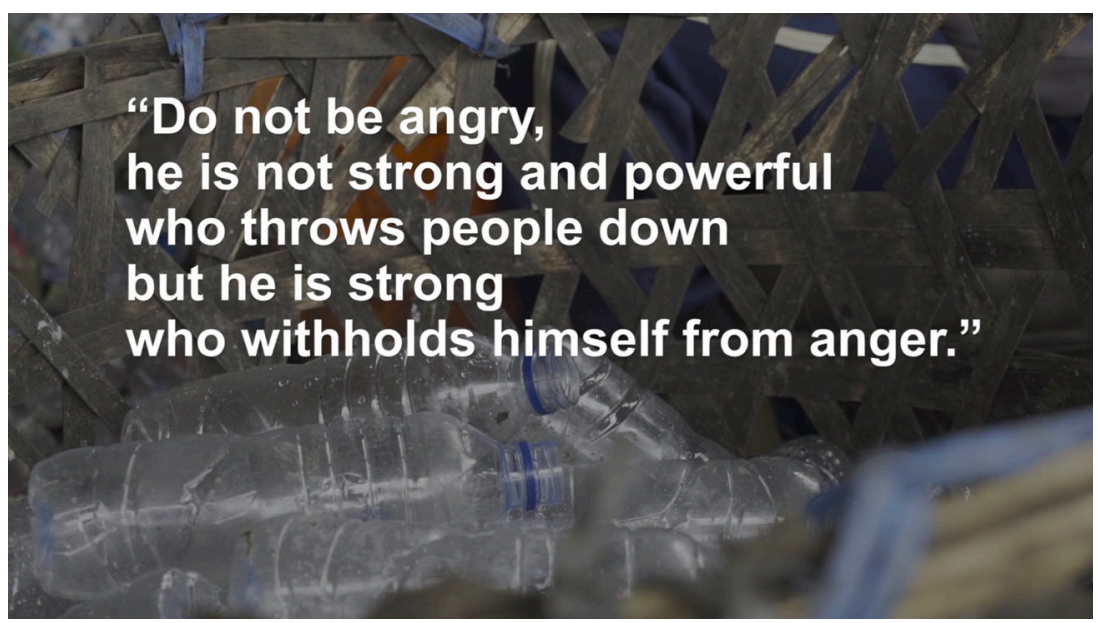

Video 14: Don't be angry (03:19).

Source: Scraps of Hope.

To watch this video, scan the QR code with your mobile device or visit DOI: https://doi.org/10.33134/pro-et-contra-1-video-14

(saling bersilaturahmi) in mutual brotherhood/sisterhood, and not be hostile to one another. Although, for example, our religion is different, a smile is also necessary for that person, conversation is needed. Do not say that a person who has a different religion should be distanced.

The important thing is that in our hearts we do not have a sense of violence ... emotions will always be there, but we have to stay aware of our emotions, even if things get bad.

Approaching the topic ethnographically through Dedi's narration allows us, firstly, to question predetermined notions of a suffering wage labourer; secondly, it extends the understanding of queerness in Banda Aceh beyond specific sites of labour and livelihoods, exploding the myth that queers, especially transwomen, are only employed in the beauty salon business. Thirdly, as illustrated above, the 'misrecognition' allowed Dedi to narrate their version of piousness and the connectedness of their experiential life-world to material reality, and also religiosity, to being connected with their God. Dedi's story is their ijtihad, or independent interpretation of their practice of religion. They consider their situation a test of endurance, possibly resulting in fortune or prosperity and the adaptation required to endure potential hatred, and even outright discrimination: 'I am here for the job, not for making enemies.' On the other hand, Dedi clearly indicates where the status quo is going wrong (God is 
angry at humanity), offering a vision of brotherhood and solidarity - akhlak (striving towards virtue and piety) - not just for themselves, but for the whole of humanity. In other words, on the short-term micro level, work at the recycling centre is an attempt to make ends meet and ensure economic security, meanwhile managing the job's consequences for psychological and physical health. Yet, at the same time, these observations are combined with structural and philosophical levels (longer-term analysis of the system's need to change): God is angry with humans - we need to change our behaviour (akhlak), our practice of virtue, morality and manners.

Dedi's analysis also traces the changes taking place during the first decade of peace:

Before, there was feeling of being cautious, because one had to carry an ID card, and thanks to God we had one. Earlier, without one, right! ID cards are now secure, so going from one place to another is easier. Earlier, no matter what you did, it was wrong (mau sana salah, kesini juga salah), due to the two conflicting parties and their intimidation of civilians, but now things are fine and it is pleasant.

When asked what Dedi would like the government to do in terms of the people's well-being, the answer was the following:

To share real peace; for those who are unemployed, [there should be] work, open new job opportunities ... For example, nowadays there are many school graduates, some are high school graduates or ST, now surely people need money and jobs. It's not that we say that those who don't go to school are not needed, why would we require that? People are truly needed. So it's like nowadays college kids have finished higher education ... but whether they finish it or not, they do not know where they should go [to make it happen]; one has to have inside connections, who help us get jobs. Even now my college student friends are unemployed and do not know where to go from here.

So to open one's mind like this: ... what are these shortcomings one can record within the community ... for example what does the village community lack? Water connections, there is no water, right. What's the shortage? The economy is insufficient we say. What can be done about it? Rice, oil and so on.

As regards the accelerated economisation of bottled waters, the manager of the recycling centre suggested: 'Such plastic recycling only became possible in the aftermath of the tsunami' (9 December 2015). Tsunami waste disposal, and building the city anew, has thus provided economisation in the form of plastic 
recycling. This centre is a nodal point in the middle of the flow of bottles and cups; this is where the collected cups are processed in order to be sent for further processing. Tight schedules have to be followed, as the premises only allow stockpiling of a limited amount of cups, yet the vicinity to the landfill site has meant that a number of similar businesses have opened on the same road. The importance of the income is explained through the common local idiom, 'Hana kerja hana penk ... hana inoeng ...' (no work, no money, no woman) (9 December 2015).

His aspirations for further economisation and improved economic turnover are clear; however, he faces a number of challenges: firstly, there are those who took advantage of aid investment available at the time of the reconstruction, and the manager and the Gampong Java neighbourhood were left feeling cheated; and secondly, being a newcomer (pendatang) has meant that he has received very little serious support for the recycling activity from the municipal government.

They do not accommodate our aspirations ... like I said before, we are still regarded as outsiders here ... People from most of the outer regions, from Medan ... are still considered migrants, even though we have an ID card here ... First one is considered an outsider and after that the support is not there.

Yet, despite the local-level realities of living in the aftermath of ethnonationalistic armed conflict, this neighbourhood and the recycling centre are connected through Facebook to a network of those who have made the economisation of recycled PET into a serious business. The example of Malang in Java (group called Masyarakat Sadar Lingkungan, discussed in Facebook group Bank Sampah My darling) is suggested as an example that local authorities could also follow in Banda Aceh. The question of how long one remains an outsider or newcomer is contested and political, as even the name of the neighbourhood, Gampong Java, connects the ethnic Javanese intimately to the colonial history of the archipelago. Javanese troops who fought the Portuguese under the rule of Raden Patah (King of Demark) had stayed on in Aceh and established villages or neighbourhoods that were named after their island of origin. 'Newcomer' in current usage, however, often refers to post-tsunami migrant newcomers, who seem to occupy the same locations in the city as the troops of the past. These areas are directly connected to common stereotypes of 'bad neighbourhoods', hosting drinking, prostitution and crime, but, importantly, their task is to keep up with increasing consumption, middle-class aspirations and, thus, a growing need for waste management in the city.

Furthermore, the experience of lack of support for recycled products, including handicrafts, is in huge contrast with the efforts to promote Acehnese handicrafts via an association (Dewan Kerajinan Nasional Daerah, Dekranasda) 
(Srimulyani et al. 2018) whose task is to publicise them via exhibitions and showrooms. In fact, the frustrations expressed by the recycling centre manager situates him in a similar outcast position as Banda Aceh punks (Jauhola 2015a; Bolong and Jauhola 2017) who were learning to make miniature motorbikes from used cigarette lighters, something picked up from the mobile punk community in the Indonesian archipelago. The frustration with international aid getting into the wrong hands, along with being treated as an outsider, were clearly reflected in the interview:

They interviewed us, got our signatures and the money was gone ... the money meant for the purchase of machinery, the money disappeared until people ... used it to build their houses. Why did X withdraw that money, for it to be spent like that? For 6 months the money was used for everything, and once gone, no sign of them. They pulled out, one by one. These people wanted to collect the plastic that we were going to crush; for six months the project was running, then the manager disappeared. People dispersed the funds and equipment. So now we transport the materials to Medan. We were supposed to have the facilities locally, but instead we got a kick from their boots.

People who work here are mostly unemployed, a lot of mothers. If they are not busy, we also carry the plastic into their homes for preparation. They are in charge of cleaning and processing the cups. This means they are able to do their domestic duties, such as cooking, and at the same time earn money - quite different if they were working here, where they'd not be able to take care of their children and cooking. So when the child falls asleep, she can start cleaning the aqua [cup]. This means they can earn 1,000 or 2,000 Rp. This is for the environment, right? To clean it up. We need to clear the rivers of the water cups, and then we ask [the women] to clean them up.

His reflections highlight at least three important observations, the first of which is a common value-chain problem that is prevalent in all economic activities in Aceh. Aceh produces considerable quantities of raw materials, but turning them into more profitable products takes place in other regions, such as North Sumatra. When I asked about this value chain more directly in a 2018 meeting, the manager provided exact calculations:

Clear PET bottles in Medan, the capital of Northern Sumatra, earn $6,200 \mathrm{Rp} / \mathrm{kg}$, and mixed ones, 5,800 Rp/kg. Separating the coloured bottles from the clear ones has not made economic sense, so washed and pressed bottles get 3,800 Rp/kg locally in Banda Aceh, after which they are transported to Medan for further processing, and transportation costs [100 Rp/kg] are added. Yet, compared to the situation in the 2015 
interview, the situation has slightly improved; there are 13 new workers, although finding a committed work force has proved difficult. All together there are 15 bottle-recycling entrepreneurs in active discussion with the neighbourhood leaders (aparat desa) about the possibility of further developing this sector as a neighbourhood strength to counter the common stereotype that 'there are lazy people living in Gampong Jawa'.

Secondly, the economisation of recycling provides an important earner for the lower-waged classes and the urban poor, particularly married women who are engaged in home-based economic activities, as the analysis of post-tsunami microbusiness support suggests (Srimulyani et al. 2018). Thirdly, their labour contribution has become an essential part of the rebuilding of the kota madani: cleaning the environment, and thereby re-imagining the 'aesthetics of cityscape' (Chakrabarty 2002, 66) along the lines of the Cleo water bottle advertisement.

\subsection{Street Economics: From an Internally Conflict-Displaced Preman Economy to Social Rafting}

In Chapter 4, the political economy and post-conflict masculinities of an excombatant's family were analysed in detail. This section revisits their coffeeshop-cum-home to pay specific attention to the roles played by recycling in their everyday economics since the ex-combatant left the preman gangs and focused on healing therapies and the coffee shop business. Essentially, theirs is the story of a transition from the preman economy to one of social rafting between poverty/daily survival and changing needs due to ageing, illness and growing grandchildren. The analysis focuses on three aspects: the arrival of bottled water as a result of reconstructing the city and new customer demands; the insufficient availability of municipal tap water for domestic water needs; and the arrival of plastic recycling as a means to stretch the tight economic situation caused by the urbanisation and gentrification of coffee-shop culture and the heart of the city.

Having received tsunami-aid funding to reconstruct their wooden coffeeshop-cum-home after months of being housed in temporary tents and barracks far from home, their initial contentment with gaining stable livelihoods in the busy section of the city has been coloured by new challenges and uncertainties. Alongside the reconstruction boom and the risk that a low-rise storage house behind their coffee shop would be torn down, taking their shop with it, came the expectations that coffee shops and restaurants would now serve their customers bottled water instead of boiling and filtering it, which had in the past been sufficient. This aligns with analysis in other contexts which has suggested that the introduction of bottled water has always relied on its marketisation as 
being safer than, say, municipal tap water. This line of argument has resulted in middle classes across the globe considering that only bottled water is potable (Hawkins et al. 2015, 1754/5473) - a feeling of insecurity causing 'ontological anxiety' which has social, cultural and economic consequences. This particularly affects those with aspirations to belong to the middle classes in terms of taste and distinction, meaning that the emergence and availability of bottled water also brings about new practices (ibid., 1766, 1811/5473).

For those shopkeepers whose daily business and, consequently, cash flow is healthy, stocking and storing water bottles, or water cups purchasable for 10,000-20,000 Rp per box of 48, becomes a daily or weekly routine - just like the purchase of other essential items, such as coffee, tea, cigarettes, snacks and cakes, instant noodles, vegetables, eggs or even fish or meat to cook on the spot for hungry customers. However, the cakes and snacks are sold in collaboration with local bakers who bring the items for sale in the morning in plastic containers, which are then collected, together with the takings, each evening; such arrangements, or longer-term repayment schemes, are not available with water. The couple's calculations, taking their total daily stock needs into account, led them to limit their original menu - initially made available with the help of post-tsunami capital. The changes between 2012 and 2014-2015 were clearly visible. They no longer served the fresh juice that their now tattered banner advertised; nor the fried noodles or multiple brands of cigarettes. Instead, they simply served coffee, tea, water cups, individual cigarettes that were purchased both for their own use and for customers on demand, and one copy of a daily newspaper - a regular feature of all coffee shops in Aceh.

When visiting the family one day in mid-May 2014, the ibu warkop complained that, despite the fact that they have access to municipal tap water, there had not been a single drop for the past four days; this had given rise to concrete challenges in terms of personal hygiene and sanitation, and also meant that the laundry was left undone. For a family of three generations with limited clothing, it meant struggling with cultural and social norms of cleanliness, also with regard to their grandchildren's school uniforms. When the smooth provision of water was restored, however, the family also started refilling water bottles (19 litres) and selling them to outsiders in need.

In 2014 and 2015, recycling became an important part of diversifying daily and weekly income for the family. This overall situation connects their everyday to the observation made in earlier research: bottled water relates to the question of water shortage, but also the economisation of waste to compensate poverty (Hawkins et al. 2015; also in Prasetiawan et al. 2017). In their case, it meant using the extra earnings for medicine, but also to support the schooling and clothing of their grandchildren.

Ibu warkop was preparing for the recycling collector's arrival, gathering tires, carbon boxes and plastic. The grandchildren had also learned to recycle. $\mathrm{R}$ found an empty cigarette package and took out the inside 
paper and threw it to the front of the coffee shop, which had become, since my last visit, the main site in their coffee-shop-home for recycling. Food leftovers are handed over to their son who raises ducks, and in return they get eggs.

Fieldwork notes 2018

How should this situation be understood? On the one hand, they were realising a diversification in the economy and everyday materiality of their lives; waste that they and the neighbourhood produced - and the municipality's requirement to 'keep Banda Aceh clean' - provided the opportunity to earn extra cash. It also translated into a concrete capacity for 'pragmatics of valuation' (Caliskan and Callon 2009, 388 quoted in Hawkins et al. 2015), which refers to the praxis of calculating what to collect and what might have the potential for new value in their economy. On the other hand, this example also highlights a different kind of economics at play, one without monetary value, but, rather, which is a part of the older tradition of gotong royong, or shared economy between extended family members, which analyses poverty by focusing purely on earned income, incomplete as regards understanding levels of economic insecurity and ways of negotiating and socially rafting one's situation (Vastapuu 2018).

\subsection{Commodification of Water in a Middle-Class Family}

The Dreamcatcher video is the story of a woman who migrated and got married in Banda Aceh. How to make the dreams of her family's well-being come true?

In Aceh, as in many other material cultures (Hawkins et al. 2015, 1925/5473), water plays an important part in practices of hospitality. The turn away from tap water use in households has meant, for example, that small water cups have replaced the practice of offering guests a glass of filtered water mixed with a flavoured syrup on arrival. This has also led to other innovations associated with the water cup. In 2015, the Family Welfare Programme (Pembinaan Kesejahteraan Keluarga, PKK), which plays an important role in governing and constructing gender norms and notions of the ideal household (Wieringa 1992; Robinson 1995; Rinaldo 2002; Blackburn 2004a; Jauhola 2013), organised special training for the women in the neighbourhood I often visited in making water cup holders. These were part of an attempt to diversify home-based small businesses in the neighbourhood, which often focused on handicrafts and food production (Srimulyani et al. 2018).

Holders later appeared in all the reception rooms where visitors are met and offered water and snacks. On several occasions, I was invited to sit on the floor of the front reception room in a house, on a rug and pillows, with a plastic bottle holder placed in the middle. During the day, women would gather together on the floor to socialise (usually described as 'gossiping'). On many occasions, however, these exchanges were also situations for social negotiation, neighbourly competition and laughter, and were also used as lorong 


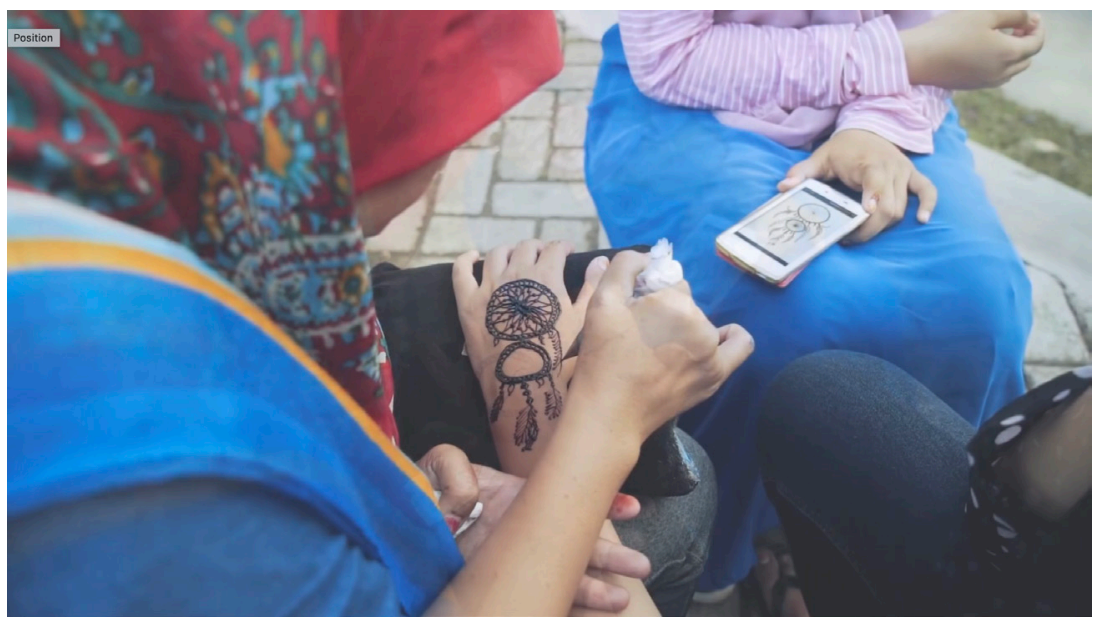

Video 15: Dreamcatcher (06:24).

Source: Scraps of Hope.

To watch this video, scan the $\mathrm{QR}$ code with your mobile device or visit DOI: https://doi.org/10.33134/pro-et-contra-1-video-15

(street-level) conflict-mediation fora. On one occasion, such a gathering took women from one house to another, then they invited me for a motorbike ride to the beach and back to the neighbourhood. The occasion was used to discuss an ongoing conflict over the young female student tenants who were renting a room from one of the neighbourhood women. The young women were feeling pressured and unhappy, and had approached one of the women (and her husband) to ask them to intervene.

On another occasion, the same family took me to the newly opened water park in Banda Aceh. At the time, tickets for the whole family were outside their normal budget, but with gifted tickets, the visit became possible; given the increasing water crisis in the city, it was an overwhelming experience. The park was busy with families with children, but also adolescents and young adults who could clearly afford the ticket price. At that time, it was the only park in town, and this family, who kept a close eye on trends in urban cultures outside of Aceh - mainly due to family connections to Northern Sumatra - judged that it was nothing compared to similar water parks in other parts of Sumatra or Java. As of 2019, the park in Banda Aceh is permanently closed, but two other bigger locations have been opened, one in Mata Ie, and the other a little further away from Banda Aceh in Indrapuri.

Mata Ie's situation illustrates the seriousness of the slowly emerging, or perhaps sustained, water crisis in Banda Aceh and its surrounding areas, and its complexities and connectivity to urbanisation, investment in the tourism sector and also the commodification of water. Mata Ie has been famous for its water 
springs (mata ie translates as 'eye of water', or water spring) since the times of the Sultanate, and the famous Acehnese folksong, Krueng Daroy-Rafly, tells of how the Sultan's daughters used to bathe in Mata Ie's rapids. Since those times, Mata Ie has been an important water source for the Banda Aceh residents. Over the years, several bottled water companies have been established in its vicinity (such as Ie Cleen). In 2019, however, serious disruptions occurred to the water supply in both Banda Aceh and the neighbourhoods surrounding Mata Ie, and residents became once again reliant on water relief provided by the police with water tanks. According to speleologist Abdillah Imron Nasution, since 2006 the river flow and the area's whole ecosystem and water catchment area has been severely affected due to deforestation and overuse of land; restoration requires serious efforts (Serambi Indonesia 2019b).

\subsection{From Shadows of Political Economy to Seeking Just Futures}

In 2014, I received an invitation to lead a 'gender session' as part of some internal faculty training at the Islamic State University Ar-Raniry in Banda Aceh, belonging to a wider research training initiative aiming to address the scholarship on sociology of religion at the campus. Given my critical approach to any form of 'gender training' (Jauhola 2013), I decided to approach it ethnographically. Arriving at the hotel premises, the set-up was familiar from my earlier career as a humanitarian aid worker (Martini and Jauhola 2014). I entered a post-disaster urban spatiality that was reserved for upper-middle-class guests and replicated globalised lifestyles and aesthetics: buffet lunches, swimming pool, seminar room with air conditioning - and water cups. Raising the cup in my hand, I asked the training participants for the first thought that came to mind about the cup; I then asked how they thought that a focus on materiality, such as the water cup, could illuminate both the political economy of a postdisaster city like Banda Aceh and also its gendered realities. After discussion and contemplation of the fact that the cups are 'everywhere', I narrated the story of what happens when we, the workshop participants, university staff members or caretakers of our household water consumption, throw the cup into the waste bin.

This chapter has illustrated what regaining normalcy, or 'building back better', has meant from the point of view of drinking water consumption, particularly in light of the dominance of PET bottled water in the aftermath of the Indian Ocean earthquake and the tsunami. Firstly, following the economisation of the PET bottle - or 'the life of the bottle' - allows us to see connections and disconnections in the city: the symbolic construction of middle-class ideals and piety, the amalgamation of consumption and waste into the livelihoods of the lower-middle classes and urban poor, including the queers struggling to gain respectability and uphold their dignity and piety in the city. These trajectories provide a glimpse of foolish knowledge (Ilmu Bodoh), of subaltern 
narratives of social rafting and management of daily life and livelihood strategies in urban, post-disaster landscapes. This knowledge challenges the multidimensionality, or the shadows of the bottled water's political economy, by providing both sharp criticism of the assumed normalcy created in the city; yet, they also offer, as Dedi's story illuminates, insights into the practice of piety, as well as non-violent and egalitarian visions for the future. 



\title{
Conclusions
}

\section{Centring Ilmu Bodoh Foolish Knowledge, Changing the Way in Which Gendered Peace Is Conceptualised?}

\author{
Peace, you say? \\ I was silent alone
}

Under the dark, dark sky. My heart was muttering darkly

And that question comes knocking on the soul:

Have you felt the waves of peace? Is not this country that you glorify

No more explosions

No more melancholy cries

And also no more screams full of fear? There is only a smile full of happiness

No, no, no.

My Aceh isn't safe yet. My Aceh isn't peaceful yet,

Exclaimed the best friend. Look at those sorrowful eyes. Listen to that heart-

breaking cry. Look at that frail, tired face.

Is this what you call peace?

Don't close your eyes,

They keep screaming because they suffer.

They shouted because they could not hold the feeling. But the screams were only heard in the chest cavity because they were just poor people,

Without anyone caring.

Bastards ${ }^{1}$ increasingly powerful,

Small people more miserable.

Where is the peace?

Far from the eye, from real life.

'Lia Maisarah' (Djohar 2019, 8-9)² 
As Lia, one of the creative writing workshop students organised at the University of Malikussaleh in 2018, writes above, when approached from the perspective of everyday experience in Aceh, the picture of the 15 years of peace since the signing of the MoU in Helsinki in 2005 contests the constructs that suggest the peace was a 'success', or that the city of Banda Aceh or the lives of the Acehnese have been 'built back better'. On 10 December 2019, the day when these conclusions were drafted and one which is celebrated as International Human Rights Day, my Facebook feed was filled with posts that reflected on and documented an event, 'Lorong Ingatan - KHANDURI NUJÖH', organised by Kontras Aceh (Aceh Commission for Disappearances and Victims of Violence in Aceh) as part of commemorating past human rights violations in Aceh. The event consisted of a photograph exhibition, a book fair, art performances and discussions. It also included an exhibition of bamboo cages (troma tring) inside of which one human rights activist photographed herself: 'Aceh is still "locked in" the corridor memory of conflicts that are not yet just for the fulfillment of victims'rights' (@kontras_aceh \#selamathariham [Happy human rights day]). Khanduri Nujöh, used in the title of the event, is an Acehnese tradition in which, upon someone's demise, food is offered to relatives, neighbours and close friends who visit the funeral home for a period of seven days.

The chapters in this book have examined the framing of peace and the mundane everyday theorising, or foolish knowledge (Imu Bodoh), which connects the residents of the provincial capital of Banda Aceh to global processes of extractive and masculinist political economy on the one hand, and militarised hegemonic masculinity balanced with notions of gendered piety, on the other. The book has discussed how visions of the city as an Islamic model city (kota madani) and attempts to articulate notions of gendered piety or respectable womanhood are contested and negotiated, meanwhile actively creating groups that are marginalised, categorised as un-Acehnese, unfit, unchaste or even dissidents, who resist the notions of 'building a house over an already established one', as the Sufi healer put it.

One of the major aims of this book has been to narrate a journey of 'stumbling scholarship', referring to a process of ethical engagement that is aware of the politics of research conducted through the hegemony of Eurocentric scholarly praxis, neoliberal universities and extractivism. Opening the research process to the reader, the goal has been to illustrate that engaged scholarship and non-linearity of research design - forms that challenge academic empires allow the boundaries of knowledge production to be expanded, simultaneously making the exercise of power in knowledge production and regimes of truth extremely visible and shaky.

As film documentarist Carmen Baltzar asked my Visual Anthropology students one day: which mode of film-making do you think is more honest about its coloniality and positions of power? The one where the voice of God, the voiceover, provides the interpretive framework, or the one that appears not to have one - rather appearing, through neat cuts and frames, to offer a neutral 
point of view on 'everyday lives'? The latter is a new trend, at least in the study of peace-building, international relations and international political economy. Instead of framing discussion and findings through certain turns in International Relations (such as visual, ethnographic, everyday/local), peace-building or Islamic studies, the book has demonstrated that an interest in freedom, agency and urban reconstruction benefits when it is 'grounded, particularized analysis linked with global, economic and political frameworks' (Mohanty 2003, 501), illustrating how the aftermath of the tsunami and armed conflict reconstruction has created openings for new kinds of gendered contestations.

I have suggested that embodying a pedagogy of 'stumbling scholarship' provides an opportunity to negotiate knowledge production practices, and offers new ways of approaching ethnographic research and the desire to become a scholar. Such processes will not end when the last page of this book is written, nor when it is printed as a hard copy or coded into electronic format. Rather, choosing certain forms of publishing, such as short videos and engagement in social media and screenings, as I suggest, provides analytic fragility where representations, analysis and connectedness can occur in new ways, and can also be resisted.

The various chapters have provided a multifaceted image of Banda Aceh as 'a tapestry woven from countless threads, representing classes, ethnic and religious groups in their struggle for justice' (Setiadi 2014, v). It is only appropriate, then, that we consider what the main characters regard as the principal contributions made by their participation in the short videos, and the construction of their life stories:

For me, for the sake of the welfare of the wider community, I am not afraid to talk about the situation of Aceh today. We all need to know the real situation. Peace has lasted 12 years, but with what outcome? Conflict results still exist. Where are the results of peace? The ones who are rich have made others suffer. The result of the conflict can be seen in the fate of 50 thousand orphans of conflict victims. Where is that peace now? For the sake of peace that can really help the victims prosper, especially the orphans, I am ready to talk. Although it entails risks. Many homes and community lands are destroyed, the economy is destroyed; even now there are still many that have not been restored. In the name of kindness, to support a peace that pays attention to the fate of the victims of the conflict, I agree to this video being published, as a form of support to the government in providing better welfare to the community of conflict victims.

This video is a way to open people's eyes to today's situation. We support peace in Aceh, but how to support it? [We should] produce more information about the situation of the conflict-affected community. If their house is damaged, pay attention to that house. If there are still victims who are traumatised, heal them. The government needs to learn this so that they can help and strengthen the community. 
Another participant reflected on being sidelined from governmental (social security) authorities:

As of now, there hasn't been any support from the [social security] authorities. We do not have a KIP [Indonesian Smart Card issued to citizens] as the district head has not issued it to us; we are poor people. My other neighbours get assistance from the [municipal] government but we are left out, not told of the social benefits available. A neighbour has taken issue with us; our house has been stoned on many occasions, our well was contaminated with cow and dog dung by them. Because I am poor and ostracised, those who are better off hide the fact that they gain social benefits. Farming assistance, for example: we who have started polybag gardening have not received capital assistance because we do not have land, just polybags. It would be better to beautify our gardens and living environment. There is a vacant plot which is not being used.

Usually the process of gaining assistance is handled by the village head with groups. Others gain help from anywhere, whilst I am left out and considered heretical because I pray often and they become disturbed by it. Once my polybag crop was stolen and they became intimidating when I asked them where [the vegetables] were. Once I reported it to the village head but was just ignored. We only have access to KKH (Conditional Cash Transfer Programme for Poor Families). Assistance is needed for damaged houses. My house was built by an NGO in 2006 (as tsunami assistance), but it's been damaged now for several years, especially as stones were thrown by the neighbours. They did not like the way I pray and I was considered to be a black magician. Some slander me. They still slander me.

My child studies at the university and she is already in the 7th semester, and my youngest one is in the 1st semester at another university. I have received education fee assistance from the Islamic Relief for 1.4 million Rupiahs for a quarter of a year, totalling half a year. But not anymore. I am yet to pay the school fees of my older daughter because my efforts now go towards supporting the education of my younger son. We urgently seek assistance for polybags and house maintenance at the moment. My land title was bigger before the tsunami but it has been grabbed by the neighbours. The school fees are high and I continue working to pay them. My husband died in the tsunami.

This was the advice given by Mila and her husband:

We should not be lazy. Do not be discouraged and do not despair. Be patient, pray and try. People need to be diligent about fulfilling their own needs, yet the government should pay attention to the fate of 
people like us. Right now we survive thanks to our own abilities. We got no help from anyone. We've survived from day one and have cried over our losses. Our luck is that we had the toy train business and we got capital when we sold it for 10 million.

Help the ordinary people. How to do it: the government must intervene to improve the economy of the community. They should find out who is yet to be assisted. My offspring are not the descendants of beggars. I once asked for 10 million Rupiahs and I was given 1 million. This is insulting. So I no longer want to ask for capital aid from the government. Many walk into the government office hungry and with empty stomachs. And there are many who put up with the shame of asking like that, but who are not given. Even asking is a major struggle for many. The peace agreement of Helsinki has already promised things such as: (1) providing land for building houses to replace those damaged and destroyed; (2) rebuilding the damaged and destroyed houses; and (3) providing business capital. If there are those who harvest successfully, help others by sharing the seeds.

Who should have the priority? This is what the Sufi healer had to say:

There should be welfare benefits for the orphans of the conflict victims. Graves are nowhere to be seen. Orphans of the conflict are not cared about. The poor in the village are not cared about. If there are conflict victims' orphans who are still traumatised and not provided education, restore and ease their path. No one wishes to beg. However, if the government wants to care they have to be able to provide welfare for these people. My principle is this: make welfare a reality for those children who are humiliated and left in Acehnese houses today. Provide children with their education. The poorest of the conflict victims should be identified, their livelihoods and skills improved.

Do not give Acehnese people fish, as they are lazy about work, often just waiting for the government to assist them. If they have the skills to trade or farm, people can do it themselves. The government is responsible for enabling the conflict-affected people to earn their livelihoods through work. Do not give money. But open the eyes of people. Do not give a million Rupiahs per month, but give what they need: fishermen need capital to be able to fish again; those who trade require business capital; those who farm require capital for seed. But if you announce a delivery of $40 \mathrm{kgs}$, do not reduce it in reality to just $5 \mathrm{~kg}$.

This book has explored how the first two decades of peace in Aceh gain new dimensions when the focus is on the perspectives of urban subalterns and those 'written out of [the] history' (D'Costa 2006, 129) of the official peace fable. Yet, 
not a single definition has been offered as to what to make of 'scraps of hope'. The Cambridge dictionary offers the following meanings for scrap:

As a verb:

- To not continue with a system or plan

- To get rid of something that is no longer useful or wanted, often using its parts in new ways

- To have a fight or an argument

As a noun:

- Old cars and machines or pieces of metal, etc. that are not now needed but have parts that can be used to make other things

- A small piece of something or a small amount of information

- A fight or argument, especially a quick, noisy one about something not important

As for hope, it is time to return to what Eve Sedgwick (2003, 146, emphasis added) has to offer:

To recognize in paranoia a distinctively rigid relation to temporality, at once anticipatory and retroactive, averse above all to surprise, is also to glimpse the lineaments of other possibilities ... [T] o read from a reparative position is to surrender the knowing, anxious paranoid determination that no horror, however apparently unthinkable, shall ever come to the reader as new; to a reparatively positioned reader, it can seem realistic and necessary to experience surprise. Because there can be terrible surprises, however, there can also be good ones. Hope, often a fracturing, even a traumatic thing to experience, is among the energies by which the reparatively positioned reader tries to organize the fragments and partobjects she encounters or creates. Because the reader has room to realize that the future may be different from the present, it is also possible for her to entertain such profoundly painful, profoundly relieving, ethically crucial possibilities as that the past, in turn, could have happened differently from the way it actually did.

So, of what do scraps of hope consist, you may ask? Based on all of the above, how should we narrate the everyday peace in Aceh? What does a theory of peace from the perspective of foolish knowledge (Ilmu Bodoh) look like?

Use the next page to write down your thoughts and send it to scrapsof hopeoffice@gmail.com or leave a message at https://www.facebook.com/scraps ofhopeurbanethnographies/. Let's keep the dialogue going! 


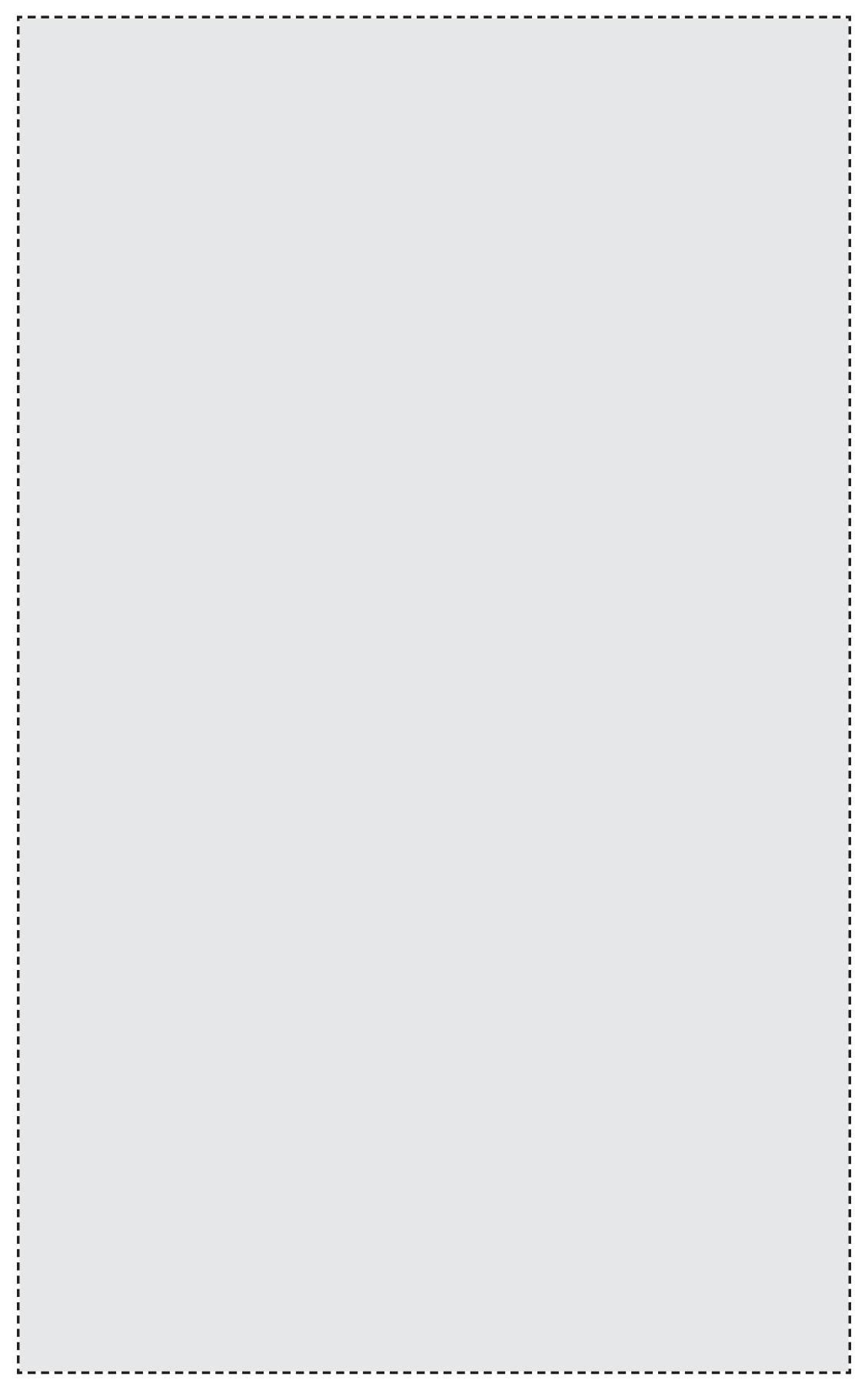





\section{Glossary}

3Bs Beragam, Bergizi, Berimbang dan aman, producing meals that were diverse, nutritious, balanced and safe

Adat local custom, customary law

AEC ASEAN Economic Community in Indonesian, Masyarakat Ekononomi Asean MEA

AGAM Forces of the Free Aceh Movement, Renamed the Army of the State of Aceh (TNA) in 2002

Akhlak practice of virtue, morality and manners, or good Islamic character al-haya reticence or modesty, piety

Amar Ma'ruf Nahi Mungkar enjoining what is right and forbidding what is wrong, Quran Al Imran 104

AMDK Air Minum Dalam Kemasan (bottled water)

AMM Aceh Monitoring Mission

Anak buah Ibu officers working under the (vice) mayor Illiza

Aqidah belief

ASEAN Association of South East Asian Nations

Bapak fatherly, patriarchal

Bimeren ritual among Gayo

BPP Biro Pemberdayaan Perempuan (Agency for Women's Empowerment)

BPPPA Badan Pemberdayaan Perempuan dan Perlindungan Anak (Office for the Empowerment of Women and Protection of Children) 
Build Back Better a slogan adopted for the post-tsunami reconstruction aid use after the Indian Ocean earthquakes and the tsunami in December 2004 CEDAW Convention on the Elimination of all Forms of Discrimination Against Women

CMI Crisis Management Institute

CRS Catholic Relief Services

Dakwah (Ar. da'wa) Islamic religious propagation

DOM Dearah Operasi Militer (Military Operation Area)

Dosa sin

DPRA Dewan Perwakilan Rakyat Aceh (People's Representative Council of Aceh)

DDR Disarmament, Demobilisation and Reintegration

Duek Pakat Inong Aceh Second Acehnese Women's Congress

Dutch colonialism known in Aceh as the 'Dutch War' (Perang Beulanda), 'Infidel War' (Perang Kaphé) and 'Holy War' (Perang Sabil)

FKUB Forum Kerukunan Umat Beragama (Inter-Religious Harmony Forums)

FORKAB Forum Komunikasi Anak Bangsa (militia group in Aceh)

FPI Front Pembela Islam (Islamic Defenders Front)

GAM Gerakan Aceh Merdeka (Free Aceh Movement [1976-2005])

GBI Gereka Bethel Indonesia (group of Pentecostal Churches in Indonesia)

Gerwani Gerakan Wanita Indonesia women's communist party organisation

GOI Government of Indonesia

Haram forbidden

Hari I $\boldsymbol{b} \boldsymbol{u}$ annual celebration of mother's/women's day on 22 December, with contested meanings

Hizbut Tahrir established in Jerusalem in 1953, with the aim of restoring the 'caliphate' lost when Ataturk officially ended the Ottoman Empire in 1924

HTI Hizbut Tahrir Indonesia - emerged formally in the post-Suharto era in 2000 , although its roots go back much further to when it started clandestine mobilisation at grass-roots levels during Suharto's New Order

ICJR Institute for Criminal Justice Review

Ikhtilah physical affection and/or sexual intimacy between an unmarried couple, mentioned in various versions of the Islamic Criminal Law Qanun Jinayat between 2008 and 2014.

Ilmu Bodoh foolish knowledge, subaltern theorising as suggested by the Sufi healer during the Scraps of Hope recordings in December 2015

Infaq Arabic word meaning spending, disbursement, a gift given to please God without expecting any favour or return (see QS al-Isra, 100)

IWD International Women's Day

Jam malam curfew

JICA Japan International Cooperation Agency

Jihadakum Arabic, struggle or effort, but the exact meaning can be as varied as spiritual struggle within oneself against sin, or fight against the enemies of Islam. The verb used later in the sermon, 'leaving for', suggests the latter.

Kaffah full implementation of Sharia law 
Kafir infidel, but also used of the Dutch colonisers

KAMMI Kesatuan Aksi Mahasiswa Muslim Indonesia (Muslim Students Association)

Kawin kontrak contract marriage, nikah mu'tah in Arabic

Kesbangpol, Direktorat Jenderal Kesatuan Bangsa dan Politik Kementerian Dalam Negeri political office of the provincial government

Keuchick head of village or neighbourhood

Khalwat close proximity in isolated places between members of the opposite sex who have no kin or spousal relationship, stipulated as an offence in the provincial by-law Qanun 14/2003

Khilafah caliphate, refers to humans as trustees of a God's mission on Earth, responsible for managing life on Earth

Kiai religious cleric

Kitab Mujarabat book of recipes, in Arabic 'tested' or 'tried and true'

Kodrat intrinsic nature of woman and man, or 'God's will' and 'creation of God'

Kota madani civilised city. Madani is an Indonesian concept deriving from

Arabic, translating as 'civil', but also 'sophisticated' or 'refined'. Madani also refers specifically to the city-state of Medina and Muhammad's role in building the city after departing from Mecca in the 7th century.

Kota ramah gender 'gender friendly city', introduced after the Habitat II Conference, Istanbul Cities Summit, in 1995

Liwath male-to-male anal sex

LOGA Law on Governance of Aceh (number 11/2006), passed in July 2006

Merantau migration

MoU Memorandum of Understanding, peace treaty signed on 15 August 2005 by the Government of Indonesia and GAM

MPU Majelis Permusyawaratan Ulama (Ulama Consultative Assembly)

Muhrim unmarriable kin

Muhtasibs had the role of overseeing the implementation of Sharia principles in trade

Musahaqh sexual arousal between females that is caused by rubbing their vaginas or other body parts

Muslihat achieving one's goals through ancillary or indirect means

Musrena Musyawarah Rencana Aksi Kaum Perempuan women's budgetary planning meetings before the formal musrenbang (Musyawaran Perencanaan Pembangunan) meetings, citizens' participation in development planning

Nikah siri unregistered marriage, other commonly used form is village marriage (nikah k/gampung)

NU Nasdatuh Ulama (traditionalist Muslim organisation, founded in 1926)

Pagee gampong vanguard of the village

Pajak Nanggrö̈ 'taxing' businesses, informal taxation during the armed conflict

Panca Dharma Wanita 'five duties of women': to be loyal companions to their husbands; to procreate for the nation; to educate and guide their children; to regulate the household; and to be useful members of society 
Pancasila Indonesia's five-point state ideology

Panglima Sagoë Acehnese word for sub-district commander. Sagoë, sub-district, refers to a civilian administrative unit, but also the military structure of GAM. Aceh was divided into 17 regions (wilayah), each of which was composed of four districts (daerah), several sagoës and villages.

PET polyethylene terephthalate

PKK Pemberdayan Kejahteraan Keluarga (Family Welfare Programme)

PKS Partai Keadian Sejahtera (Prosperous Justice Party)

PPP Partai Pembangunan Persatuan (United Development Party)

Premanisme refers to (state) organised street gangsterism, often seen as an inherent part of former President Suharto's regime, crony capitalism, and its reliance on the state violence and protection system. It can be traced back to the Dutch word vrijman, which means a sovereign and free man. In Aceh, the word is used for different types of gangsters or informal profit making.

Priawan female-to-male transgender, derives from the Indonesian words pria and wanita

P2TP2 Pusat Pelayanan Terpadu Pemberdayaan Perempuan (Integrated Services Centre of Women's and Children's Empowerment)

Qanun Shari'a legislation, or by-law in use in Aceh

Qanun Hukum Keluarga Law on Family Law debated in public in 2019

Qanun Jinayat Islamic Criminal Law passed in September 2014

Rahmatan nil Alamin mercy/grace for all creatures, a universal principle towards all God's creations

rencong Acehnese knife

Rex incident arrest of several punks in November 2013 at the Rex outdoor food court

RPJMD rencana pembangunan jangka menengah daerah (long-term regional development plan)

Sabr perseverance in the face of adversity

Satpol PP Civil Police

Serambi Mekkah veranda of Mecca

Shari'a/syari'at Islamic Law

Shira' al-fikri to contest and overthrow ideologies that are incompatible with Islam, such as capitalism, feminism, communism, socialism, imperialism and infidels

Smolna government banquet hall in Helsinki, site of the signing ceremony of MoU

Solidaritas Perempuan Women's Solidarity for Human Rights, NGO

State Ibuism ibuisme negara state ideology of motherhood established during the New Order period

Syiar da'wa great da'wa

Tafa'ul ma'a al-ummah interaction with the wider society through study circles, while also reaching out to wider Islamic ummah (tsaqafah jama'iyah) and taking part in public debates 
TAMAR Tim Amar Makruf (neighbourhood vigilante teams established during the leadership of Vice-Mayor Illiza)

Tastqif disseminating HT(I)s culture

Tim sukses election team

Ummat religious community

Ustad honorific title

Wali Nanggroe literal translation 'guardian of the state', traditional leader position established after the MoU Helsinki

Waria an Indonesian word that derives from the words wanita (female) and pria (male), a term commonly used for male-to-female transgender since the 1980s in Indonesia

WH Wilayatul Hisbah (Shari'a Police force in Aceh)

WLUMN Women Living Under Muslim Law - a solidarity network established in 1984

Yaumil mahsyar (Yawm al Mahsyar in Arabic) period in the afterlife in Padang Mahsyar, a broad, flat place with white, sandy soil, where neither lowlands nor high altitudes are seen

Zina laws fornication or adultery laws 



\section{Notes}

\section{Introduction}

${ }^{1}$ Madani: an Indonesian concept deriving from Arabic, translating as 'civil', but also 'sophisticated' or 'refined'. The widened use of the concept masyarakat madani, often translated as 'civil society' or 'civilised society', emerged during the early 1990s, in the final years of the authoritarian regime of President Suharto. It has been specifically used in debates calling for democracy, when debating the role of religion and the state, and offered as an alternative for sipil, an antonym of militer (military). (For a detailed analysis, see, e.g., Bakti 2005.) Madani also refers specifically to the city-state of Medina and Muhammad's role in building the city after departing from Mecca in the 7th century. In Banda Acehnese urban governance usage, however, it seems to be harnessed more directly to conceptualisation of full implementation of Sharia law. (See also the uses of madani in relation to the Arab Spring in Hill 2013.) I discuss specific articulations of kota madani in Banda Aceh, and negotiations over embodying those ideals, throughout the book.

${ }^{2}$ For a lengthy discussion on the relationship between Islam, the state and modernity, see: Salvatore and LeVine 2005; Salvatore 2009.

${ }^{3}$ https://www.collinsdictionary.com/dictionary/french-english/rêverie.

${ }^{4}$ https://www.etymonline.com/word/reverie. 
5 To follow reversing research methodology, the concept of foolish knowledge (Ilmu Bodoh) is to be quoted as 'Sufi healer 2015, From ex-combatant to Sufi healer 1 (08:21) (Videos 9, 10 and 11), also quoted in Jauhola 2020'.

${ }^{6}$ I thank the anonymous reviewer for this conceptualisation.

\section{Chapter 1}

${ }^{1}$ Specifically used in the UK to refer to Black, Asian and Minority Ethnic people.

${ }^{2}$ WIMCW is an initiative that was spearheaded in the UK by UCL's students' union, aiming to address the lack of diversity in university syllabuses and higher education in more generally.

3 The hashtag was used at the Sussex Development Lecture series, Institute for Development Studies, 9 November 2017 at the lecture, 'Decolonising gender and development' by Professor Andrea Cornwall, http://www.ids .ac.uk/events/decolonising-gender-and-development.

${ }^{4}$ SOAS students'-union-led campaign, https://soasunion.org/activities/soci ety $/ 8801 /$.

${ }^{5}$ At least two recent cases actively use this logic: a letter to defend Third World Quarterly's decision to publish a piece titled 'Case for colonialism' in September 2017 (https://www.timeshighereducation.com/opinion/letters -no-filters), and an attack on gender quotas in the syllabus in the Department of Political Science at Lund, calling it 'campus war' and 'fascists and gender' (https://thedisorderofthings.com/2018/01/09/dear-hurt-male-egos/).

${ }^{6}$ See also Leena Vastapuu's similar suggestion which draws on Cynthia Enloe's work on 'feminist curiosity' and Edward Said's 'contrapunctual method' (Vastapuu 2018, 8-18), and Helena Oikarinen-Jabai's focus on the same processes in audio-visual productions, art-based research drawing on the works of Nira Yuval-Davis on 'unfinished knowledge' and 'dialogical knowledge production', Maggie O’Neill on 'ethno-mimesis' and Gloria Anzaldua on 'borderlands' (Oikarinen-Jabai 2017, 39-40).

${ }^{7}$ Several authors drawing on postcolonial politics have made the request to make a distinction between knowledge production and knowledge creation (see, e.g., Rutazibwa 2019, 166).

${ }^{8}$ See Sabaratnam 2017 for a similar critique made of the literature on international (post-conflict) interventions and how such notion of subjectivity is intimately connected to nostalgia for lost European social democracy.

${ }^{9}$ For an analysis of the piety movement among the Indonesian urban middle classes, see, e.g.: Fealy and White 2008; and Rinaldo 2013. For an analysis of populism and Islam, see: Hadiz 2016.

${ }^{10}$ For a detailed discussion of secularism, Islam and French feminism, see, e.g.: Scott 2007, 2011.

${ }^{11}$ For more on 'resonance', see, e.g., Unni Wikan's exploration of the concept, by which she refers to 'a willingness to engage with another world, life, or 
idea: an ability to use one's experience ... to try to grasp, or convey, meanings that reside neither in words, "facts," nor text but are evoked in the meeting of one experiencing subject with another' (Wikan 1992, 463).

12 'Guerrilla research' is a translation of a Finnish concept 'taisteleva tutkimus, which was introduced in the Finnish context by Juho Suoranta and Sanna Ryynänen (2014). In their book, their methodology comprises action research with world-changing goals that takes a critical stand on the topics under study, in collaboration with people in multiple positionalities.

${ }^{13}$ One of most popular such formats in Indonesia is 'Tukar Nasib' (Fate Swap), in which a poor family and a middle-class family swap their positions temporarily. Another, 'Bedah Rumah' (House Change), focuses on poor families whose houses get radical makeovers. Both are produced by Eko Nughoro, President of Dreamlight World Media, with imported formats (The New York Times 2009). The promotional material of House Change promises: 'Every family dreams of owning a nice and suitable home. However, not every family can realize that dream because of their financial situation. House Change helps families realize their dream of living in a proper home, within the course of 12 hours' (Dreamlight World Media n.d.).

${ }^{14}$ Although we felt quite safe where we were residing, the decision not to conduct further recordings or meetings at the university-rented housing proved the right decision, as some of the staff members who were using the house as their office started asking questions about our evening guests, indirectly suggesting that people were aware of the late-night script-writing sessions we had.

${ }^{15}$ See http://scrapsofhope.fi/banda-aceh/.

${ }^{16}$ See https://www.facebook.com/scrapsofhopeurbanethnographies/.

\section{Chapter 2}

${ }^{1}$ For detailed analysis of the revival of zina laws (fornication or adultery) in Muslim contexts, see: Mir-Hosseini and Hamzić 2010.

${ }^{2}$ Khalwat, close proximity in isolated places between members of the opposite sex who have no kin or spousal relationship, was stipulated as an offence in the provincial by-law Qanun 14/2003 and further amended into ikhtilah, intimacy between unmarried couples in either open or public space, in various versions of the Islamic Criminal Law Qanun Jinayat between 2008 and 2014. The latest version of the law was passed by the provincial legislature in September 2014, but it is yet to be enforced and several civil society actors aim to challenge its validity under the Constitution of Indonesia due to several other problematic provisions.

${ }^{3}$ Chat on 9 March 2016 with anonymous.

${ }^{4}$ See the videos MoU Helsinki: reclaiming back history and Shari'a and visions for peace: blueprint for just and equal Islamic law. 
${ }^{5}$ See the video in the following link: http://www.reuters.com/article/us -indonesia-religion-gay-idUSKBN0K600W20141228.

${ }^{6}$ This section was originally in Indonesian/Acehnese and translation into English is provided by Evi Sugianty.

7 Akhlak, translated as morals, character and good conduct, is a key concept used in da'wa and developing one's piety (see, e.g.: van Doorn-Harder 2006; Ayubi 2019a). See also Ayubi 2019b for a gendered analysis of classic akhlak texts and how gendered sociocultural roles are idealised as 'man-as-process', while women's value would be judged by God vis-à-vis their usefulness to men, fathers, husbands and sons (Ayubi 2019b, 1206).

${ }^{8} \mathrm{Mercy} /$ grace for all creatures, a universal principle towards all God's creations (see also how gender advocates debated this concept in Aceh during the post-tsunami reconstruction period - Jauhola 2013).

${ }^{9}$ Khilafah, or caliphate, refers to humans as trustees of God's mission on Earth, responsible for managing life on Earth. However, in political Islam, it has passed from a spiritual sense of responsibility to that of an elected political representative, a caliph, and thus such speeches remain open to interpretation, which, as shown in this chapter, is contested in the public sphere by groups such as FPI and HTI.

10 'You are the best of the nation raised up for mankind because you enjoin what is right and forbid the wrong and believe in Allah' (Surah Ali Imran (3):104).

${ }^{11}$ Formal name of the province of Aceh between 2001 and 2009.

${ }^{12}$ For anonymity, the name 'the church' is used throughout in this female member of the congregation's first-witness account. In this chapter, she is called Susi.

${ }^{13}$ Concept used by the interviewee of Acehnese Muslims who form $98 \%$ of the province's total population.

${ }^{14}$ See https://www.youtube.com/watch?v=RvsV_KNPwKc.

${ }^{15}$ I thank Donna Swita for locating the Indonesian lyrics for me on the internet.

16 Yaumil mahsyar (in Arabic, Yawm al Mahsyar) refers to the period in the afterlife in Padang Mahsyar, a broad, flat place with white, sandy soil, where neither lowlands nor high altitudes are seen. All God's creatures in the seven layers of Heaven and Earth, including angels, jinns (supernational spirits that can take human or animal form), humans and animals, gather and jostle there. Every human being on the day of trial will be present at Padang Mahsyar, accompanied by two angels, one as his escort and the other as a witness of all his deeds in the world.

17 The newspaper uses the verb mengemban, which has the meaning of both 'to be responsible for', and 'to care' or 'to nurture'.

18 When HTI was judged as unconstitutional in Indonesia in 2017 (Osman 2018), the locally administered sites were changed, and the contents are analysed from screen captures taken in 2015. The main campaign site still exists and it is maintained by HT's central media office. 
${ }^{19}$ HTI differentiates between capitalist/secular globalisation and what they advocate as Islamism, an alternative globalism (Nurdin 2015, 81).

20 Tanoh Rencong, Land of Rencong Knives; rencong refers to the Acehnese knife.

${ }^{21}$ Women Living Under Muslim Law, a solidarity network established in 1984, with a coordinating office in London and, currently, regional offices in Dakar and Lahore, had in 2015 supported Solidaritas Perempuan in conducting a study of the codification of Qanun Jinayat with certain interpretations of Islam.

\section{Chapter 3}

${ }^{1}$ When needed, pseudonyms are used to protect the women's identity.

${ }^{2}$ Direct quotes translated from Indonesian by Evi Susianti, Mifta Sugesti.

3 Muhrim (Indonesian, mahram in Arabic) refers to unmarriable kin.

${ }^{4}$ Direct quotes translated from Indonesian by Evi Susianti, Mifta Sugesti.

${ }^{5}$ Interviews held in English.

\section{Chapter 4}

1 The main character in three biopic videos, From ex-combatant to Sufi healer 1-3 (Videos 9, 10 and 11). I call him the Sufi healer in this chapter to protect his anonymity and right to privacy.

2 Premanisme (Indonesian) refers to (state-) organised street gangsterism, often seen as an inherent part of former President Suharto's regime, crony capitalism, and its reliance on the state violence and protection system. It can be traced back to the Dutch word vrijman, which means a sovereign and free man. In Aceh, the word is used for different types of gangsters, or informal profit-making.

${ }^{3}$ For the politics of the Wali Nanggroe position and its relevance to the Acehnese politics of Dutch de-colonisation, see, e.g.: Stange and Missbach 2011.

4 These resources have included reintegration funds, tsunami reconstruction projects, a special autonomy budget and local government revenues, which have been used for social bonding, but also strengthening of hierarchical 'bapak' or fatherly relations (see also Chapter 5) (Abdulah 2018, 79-80).

${ }^{5}$ See Chapter 1 for the importance of Sultanate Iskandar Muda in normatively structuring the city and his sultanate.

${ }^{6}$ For conceptual debates on hegemonic masculinity, see, e.g.: Connell and Messerschmidt 2005. Here, I follow the articulation of the term as 'certain idealized forms of masculinity ... that ... have such a grip on men's - and women's - sense of what men should be and do that they are virtually unquestioned' (Cornwall 2017, 32). 
7 See James Scott's analysis of the difference of the political, social and symbolic role of highlanders vs. lowlanders (Scott 2009).

${ }^{8}$ By this, Hurgronje refers to the expansion of the Sultanate of Aceh in the 16th century to become one of the important powers of Asia, having authority in west Sumatra (modern Padang), Asahan in east Sumatra, Pahang, Johor and Kedah (modern parts of Malaysia). Captives of the war were brought from the naval expeditions to the city now known as Banda Aceh as war soldiers, but also as construction workers on the sultan's buildings (Reid 2005, 7).

9 For changes to this in the post-tsunami reconstruction period, see, e.g.: Fitzpatrick 2012.

${ }^{10}$ All Scraps of Hope recording translations from Acehnese to Indonesian by Evi Susianti, and from Indonesian to English by Mifta Sugesti/Marjaana Jauhola.

11 Their names, regions of origin and exact location of their current residence are anonymised for their safety.

12 Partai Aceh, controlled by the GAM leaders, was established in 2008 and has campaigned since the 2009 legislative elections when they gained $47.8 \%$ of the provincial legislature votes; by April 2014, however, their support had decreased to just below $36 \%$ and in the 2017 gubernational elections, their candidate pair of former vice-governors (2012-2017) Muzakir Manaf and T. A. Khalid lost the elections to a pair of former governors, Irwandi Yusuf (Partai Nasional Aceh) and Nova Iriansyiah (Partai Demokrat), by $31.74 \%$ to $37.22 \%$. The Manaf-Khalid team filed a complaint about the election results to the Supreme Court of Indonesia in March 2017, but former governor Yusuf was sworn in as the new governor in June 2017.

${ }^{13}$ Infaq refers to an Arabic word meaning spending, disbursement, a gift given to please God without expecting any favour or return; see QS al-Isra, 100.

${ }^{14}$ Renamed the Army of the State of Aceh (TNA) in 2002, which coincided with the death of AGAM commander Abdullah Syafi in January 2002, when the coffee shop owner had already withdrawn from the battle and taken refuge in Banda Aceh with his family.

${ }^{15}$ For analysis of female ex-combatants and their negotiation of gender norms, see, e.g.: Abdela and Chavez 2007; Marhaban 2012; Jauhola 2013; Nursiti and Mustabsyirah M. Hsein 2015.

16 Acehnese word for sub-district commander. Sagoë, sub-district, refers to a civilian administrative unit, but also GAM's military structure. Aceh was divided into 17 regions (wilayah), each of which comprised four districts (daerah), several sagoës and villages.

17 This happened around the time of the 'Humanitarian Pause', a ceasefire agreement negotiated in 2000 that lasted less than a year.

18 The Acehnese independence movement (Geraka Aceh Merdeka) established in 1976 is often narrated in Acehnese ethnonationalist discourse as 
a continuation of a decolonialist struggle, firstly against the Dutch, but also as a continuation of Darul Islam. This was the first major revolt against the newly independent state of Indonesia in the 1950s that resulted in the annexation of Aceh as part of the newly formed province of Sumatra, and its later becoming a special autonomous region (Effendy 2003, 34-38).

19 For detailed analysis of Acehnese Sufi movements and their relation to political Islam and focus on Shari'a and jurisdictive reforms, see, e.g.: Shadiqin 2009; Ichwan 2016.

${ }^{20}$ For the history of merantau, see, e.g., Bowen 1997.

${ }^{21}$ One of the five pillars of Islam, a redistribution of wealth, which can be considered as a form of tax, or obligatory alms-giving.

22 Originally established in 1973, the organisation was further formalised through the Law on Governing of Aceh, and consequent by-law 10/2007; for details, see http://baitulmal.acehprov.go.id/?page_id=2238.

${ }^{23}$ Gayo is one of the formally acknowledged ethnicities and languages in Aceh, prevalently spoken in the province's highland region. The question of Gayo nationalism, and ongoing debates and conflicts over their identity as part of or separate from Acehnese, is ongoing (Aspinall 2003) and was reheated when the anthem of Aceh was formally launched only in the Acehnese language.

${ }^{24}$ Other examples, discussed in Chapter 3, concerned the control of female behaviour and the management of polygamy and divorce.

25 One recent republication of such works includes Kitab Ar-rahmah fil tib wal hikmah (Mercy in Medical Treatment and Wisdom), a book by Syekh Abbas Kuta Karang, an Acehnese ulama who lived at the end of 19th century (Abbas Kuta Karang Aceh Dar al-Salam 2017 [1853]). Snouck Hurgronje's writings demeaned this legacy, possibly due to Abbas' direct hostility against the Dutch: 'Dutch are represented as outcasts of humanity whose aim is the destruction of the countries over which they hold sway; while at the same time attention is drawn to their powerlessness in respect to Acheh' (Hurgronje 1906, 186), but also due to aligning with those who were reforming Acehnese Islam from Sufist practice. For more on medicinal knowledge, see also: Harun 1982; Wardani 2010.

${ }^{26}$ A former GAM commander turned politician. For safety reasons, he is not identified here.

\section{Chapter 5}

${ }^{1}$ See https://www.youtube.com/watch?v=2M-gIUnl2V0.

2 English translation by the author.

${ }^{3}$ For the fluidity of numbers of this arrest, see: Donaghey 2017, 182.

${ }^{4}$ It is common in Indonesia to call punks anak punk, punk kids or children, although their age varies from 12 to mid-20s and beyond. 
5 The Law on Governance of Aceh formalised the adat institution, the Majelis Adat Aceh.

${ }^{6}$ See https://www.youtube.com/watch?v=xygocESxcOY.

7 See Jauhola 2013 for analysis of the politics of the use of 'world' in posttsunami reconstruction narratives. See Chapter 2 on 'Thanks to the world park' in Banda Aceh.

${ }^{8}$ Over the years, the Indonesian Government had imposed several restrictions on the entry of foreigners and aid organisations to the province. Those were temporarily lifted immediately after the tsunami, even before the peace accord was signed in August 2005.

9 The Tsunami Museum's construction was finalised in 2009, but it was formally inaugurated in 2011. It was funded from Aceh's Reconstruction Fund, the overall cost estimated to be $£ 4.6$ million. The building's architect, Ridwan Kamil (b. 1971, Mayor of Bandung 2013-2018, architect and lecturer at Bandung Institute of Technology, Department of Architecture), won the British Council prize for Young Creative Entrepreneur in 2009 and was selected by Elle Decor as Architect of the Year, promoter of amateur gardening 'Indonesia Berkebun'. The museum was built as a multi-functional space, i.e. it provides a centrally located tsunami evacuation site, but it also hosts a permanent exhibition aiming to educate visitors on disaster preparedness and prevention.

${ }^{10}$ For detailed analysis of the use of prescription pills as entertainment in Indonesia and Asia, see, e.g.: Hardon et al. 2013; Hardon and Hymans 2014.

${ }^{11}$ For details, see the documentary 'Street punk! Banda Aceh', https://www .youtube.com/watch?v=iRTYHRgMP0E.

12 Yudi Bolong is a punk name used by one of the Acehnese punks who belonged to the Tsunami Museum street punk community for several years.

${ }^{13}$ In order to ensure his anonymity, and that of his family, only the common first male name Muhammad is used.

${ }^{14}$ Her name and details are protected to ensure anonymity. She has given her permission for my reconstruction of the events.

15 Sections that are taken from social media, either public Facebook statuses or private chats, are marked with the following references: (chat), (status) and marked with italics. When quoting original English text, no grammatical corrections are made unless the meaning is unclear. All translations from Indonesian to English, if not separately mentioned, are by the author.

16 As discussed in Chapter 4, head-shaving and ritualistic purification in rivers became internationally known due to the December 2011 re-education, and the visual documentation from the police academy compound. Such rituals have also been used by street vigilante groups and, since 2012, municipally established 'morality teams' (Tim Amar Maruf Nahi Mungkar) as part of the vision of a morally good and civilised city (kota Madani) meting out instant punishment, as a form of urban adat practice. 
17 Space does not allow discussion of the emergence of the Acehnese movement to legalise marijuana as part of the implementation of the peace settlement known as MoU Helsinki and an alternative political economic modelling actively followed and supported by some of the punks (see, e.g., Aink n.d.).

${ }^{18} \mathrm{X}$ is a punk who was arrested later for major drug possession after a period of surveillance and is now serving several years in prison.

19 Kuta Raja, or Koetaradja, is the name that the Dutch had given to the capital of Aceh Sultanate, changed to Banda Aceh in 1962 by government regulation and used in the name of the song 'Koetaradja fight' by the punk band War.

${ }^{20}$ Marsinah was an activist working for PT Catur Putra Surya in Porong, Sidoarjo, East Java, whose kidnap, rape and murder in 1993 gained international attention. She was kidnapped from a demonstration and her body found four days later. Those responsible were never brought to justice (Kontras 2015).

${ }^{21}$ Reprinted with the permission of Planet: The Welsh Internationalist, http:// www.planetmagazine.org.uk/. Originally printed in Jauhola and Bolong 2014.

${ }^{22}$ Totaliter (in English, totalitarian) is Yudi's band.

${ }^{23}$ In English, Chaos Bandit.

${ }^{24}$ Marjinal is one of the most famous punk bands in Indonesia, established in 1996, based in Jakarta. The band has formed a learning community called 'Pig Tusk' that is an open space for learning music and screen printing.

${ }^{25}$ Written as a commentary on the article by Syam and Effendi 2013.

${ }^{26}$ RAPI, Radio Antar Penduduk Indonesia, Association of Communication Radio of Indonesia, is a community of radio communication established in the 1980s.

${ }^{27}$ Cronic; in English, Chronic.

${ }^{28}$ Since those days, Nindy has also been a member of all-female metal band, Catastrophe, as their lead guitarist.

\section{Chapter 6}

1 Translated from Indonesian by the author.

${ }^{2}$ I thank Justin de Leon for a valuable discussion on the spot.

3 These spaces included secure and closed safe spaces, but also, increasingly, online (email lists and the use of social media, such as Facebook) and urban public spaces, such as the waria theatre play in 2009 organised in a public park in the city's administrative centre during International Day for the Eradication of Poverty, and a waria ambassador beauty contest in 2010 (see Jauhola 2013 for details). 
4 Waria, an Indonesian word that derives from the words wanita (female) and pria (male), is a term commonly used for male-to-female transgender since the 1980s. In this text, I do not differentiate between the English and Indonesian words for gay or lesbi/lesbian (for a detailed discussion of such terms, see, e.g.: Boellstorff 2005b; Blackwood 2011).

${ }^{5}$ In The gay archipelago, published in 2005, Boellstorff remains cautious about the desire to narrate the history of homosexuality as 'unbroken history'. However, during the past seven or eight years, these narratives have in fact become one important way in which Indonesian LGBTI organisations counter anti-LGBTI debates, using examples of cross-dressing, androgynous servants in the Sultanate of in Aceh and homosexual practices of wage migration and Islamic boarding schools, for example (Oetomo 2003 [2001]).

${ }^{6}$ Priawan, like waria, derives from the Indonesian words pria and wanita and was adopted by Acehnese activist circles in the early 2010s. Yet, in 2015, I noticed that Raiz self-identified himself as a 'transman'.

7 The formal Dutch rule lasted between 1816 and 1950.

${ }^{8}$ For other VOC sodomy sentences, see, e.g.: Oosterhoff 1989.

${ }^{9}$ See http://www.thejakartapost.com/news/2016/02/15/kalla-requests-undp -not-fund-lgbt-groups.html; and http://jakarta.coconuts.co/2016/02/26/vp -jusuf-kalla-indonesia-once-had-gay-minister-still-more-tolerant-about -lgbt-malaysia

${ }^{10}$ On its website, APCOM says it is a coalition formed in 2007 from the Asia and Pacific region to advocate HIV/AIDS concerns, in particular those of MSM (men who have sex with men); Edge Effect is an Australian organisation that supports 'genuine partnerships between humanitarian and development organisations and sexual and gender minorities (aka LGBTIQ people)'.

${ }^{11}$ In fact, Dede Oetomo argues that it was in Cairo, where the Scandinavian governments were pushing for same-sex marriage rights, that the New Order Government of Indonesia had taken its first formal position against it, although at the same time Golkar, the party in power, was actively mobilising transgender, gay and lesbian communities under the umbrella of the 'Family Spirit Consultative Councils for Mutual Assistance' of the MKGR (Musyawarah Kekeluargaan Gotong Royong) (Oetomo 2003 [2001], 117).

12 Dharma wanita refers to the following norms: to be loyal companions to their husbands, to procreate for the nation, to educate and guide their children, to regulate the household and, lastly, to be a useful member of society (Robinson 1995).

13 Pseudonym for the purpose of this chapter.

${ }^{14}$ For a discussion of the liberal epistemology of the concept of safe space and alternatives, Ferdiansyah Thajib offers a concept interstitial space: 'an affective quality of a sociality which tends to dwell in the status of in-betweenness 
rather than moving towards a categorical understanding' (Thajib 2018). This includes a constant play between individual seclusion and increased vulnerability due to increased visibility.

15 Throughout this section, I use the third-person plural pronoun 'they, their', both for reasons of privacy and so as not to assume any fixed gendered existence.

${ }^{16}$ Indonesian, meaning intrinsic nature of woman and man, or 'God's will' and 'creation of God'.

17 Here, the chosen pronoun reflects self-identified gender.

${ }_{18}$ Original Indonesian parts are translated into English by the author, Acehnese parts left as they are to allow Acehnese queer expression to emerge.

19 See Nilsson 2018 for a more detailed analysis of Illiza's Instagram portrayal of the LBGT issue in Aceh.

20 Translated from Indonesian by the author.

${ }^{21}$ See, e.g., the Why We Post research initiative, where anthropologists study the uses and consequences of social media for queers: https://www.ucl .ac.uk/why-we-post. Negotiated strategies for building a safe queer community through social media include the use of codes and symbols that often follow gendered patterns (Miller et al. 2016, 124-125).

\section{Chapter 7}

${ }^{1}$ Komarulzaman et al. $(2014,2)$ suggest that, despite boiling, samples indicate that up to $55 \%$ of the water remains unsafe for drinking.

2 Indonesia is one of the 'minor players' in the scrap plastic economy in Southeast Asia and the trade networks of illegal waste. In October 2019, the Basel Action Network (BAN) and Nexus3 reported that the Indonesian Government had returned 58 containers consisting of toxic and plastic waste from the US, although, instead of returning all of them to the US, 38 containers were diverted to India, three to South Korea and one each to Thailand, Vietnam, Mexico, the Netherlands and Canada (Basel Action Network 2019). The role of Acehnese recycling centres in this global waste trade business is not known.

3 Aqua is a brand name of the Danone Group, but it was established in 1973 by Tirto Utomo as a brand of PT Aqua Golden Mississippi, around the time when PET bottled waters came to the US market. Currently, Aqua has 18 factories across Indonesia and it claims to hold the number one position in the bottled water market. Wikipedia relates the anecdote that the idea of the company came when Tirto Utomo hosted an American business delegation and one of the delegates' wives fell sick due to contaminated water. The story intertextually repeats the ideas of purity and a mission to purify contaminated water (Opel 1999). Aqua quickly became a well-known product 
for the expatriate community in Jakarta. Danone is said to be among the four food and beverage giants globally (Jaffee and Newman 2013).

${ }^{4}$ Cleo, formally known as Cleo pure water (Air Murni Cleo), bottled water production started in 2004 and is a brand name for bottled water by Tanobel Food, formally known as PT Sariguna Primatirta, founded by Hermanto Tanoko, a former employee of Indonesian oil companies.

${ }^{5}$ It is beyond the scope of this chapter to provide calculations of the environmental impacts or costs of bottled water in Aceh, or more widely in Indonesia. Jaffee and Newman estimate that production and distribution consumes 1,000 or even 2,000 times more energy per unit volume than local tap water (Jaffee and Newman 2010, 10) and this calculation does not cover the potential costs of extraction.

6 The monument text reads: 'This commemorates the founding of Kota Banda Aceh, when Sultan Johansyah established the Sultanate of Aceh Darussalam on the 1st of Ramadhan $601 \mathrm{H}$ (April 22, 1205 AD).' Serambi Mekkah reported in 2017 that the monument compound was used by goats for grazing and is a sign that the city's livelihoods literally compete spatially with the formal governing of space in the shape of touristic sites (http:// www.tribunnews.com/regional/2017/09/11/waduh-tugu-nol-kilometer-di -banda-aceh-jadi-tempat-peristirahatan-kambing). The location in Gampong Pande is historical as it is said to be one of the oldest neighbourhoods in Banda Aceh, containing the graves of former rulers of the sultanate.

7 As of 2014, the monthly income considered below the poverty line in Banda Aceh was IDR 500,768, equivalent to $€ 29.80$ (Badan Perencanaan Pembangunan Daerah Kota Banda Aceh 2016); with daily processing of bottles, earnings can reach up to $675,000 \mathrm{Rp}$, just above this line.

${ }^{8}$ Sewing was one of the most common micro business efforts offered for women in the form of livelihoods training (Srimulyani et al. 2018).

\section{Conclusions}

${ }^{1}$ Bedebah, also a word used in the title of Tere Liye's (2012) poem collection, Negeri Para Bedebah (Country of Bastards).

2 Translated by the author. 


\section{References}

Abbas Kuta Karang Aceh Dar al-Salam. 2017 [1853]. Kitab perubatan melay al-rahmah fi al-tibb wa al-hikmah. Kuala Lumpur: Akademi Jawi Malaysia.

Abdela, Leslie and Mercedes Chavez. 2007. IOM Aceh post-conflict reintegration programme gender review: context, current situation, analysis and recommendations. Unpublished draft version dated 20 March 2007.

Abdulah, Sait. 2018. 'Militarised masculinity and the rise of a new political elite in post-conflict Aceh.' School of Business and Government, Murdoch University.

Aceh Women's Peace Foundation (AWPF). 2013. Video kampanye 16 Hari Anti Kekerasan terhadap perempuan (AWPF). Accessed 12 April 2017. YouTube, https://youtu.be/ F33wc069104.

Afary, Janet and Kevin B. Anderson. 2005. Foucault and the Iranian Revolution: gender and the seductions of Islamism. Chicago: University of Chicago Press.

Afif. 2015. 'Air PDAM sering macet, warga Banda Aceh terpaksa beli air eceran.' Accessed 14 November 2018. https://www.merdeka.com/peristiwa /air-pdam-sering-macet-warga-banda-aceh-terpaksa-beli-air-eceran.html.

Afrianty, Dina. 2015. Women and Sharia law in Northern Indonesia. London and New York, NY: Routledge.

Agathangelou, Anna M. 2017. 'Living archives and Cyprus: militarized masculinities and decolonial emerging world horizons.' Critical Military Studies, 3(2): 206-211. DOI: https://doi.org/10.1080/23337486.2017.1326675.

Agnes, Flavia. 2012. 'From Shah Bano to Kausar Bano: contextualizing the "Muslim woman" within a communalized polity.' In South Asian Feminisms, 
edited by Ania Loomba and Ritty A. Lukose, 87-90. Durham, NC: Duke University Press.

Ahmed, Leila. 1992. Women and gender in Islam: the historical roots of a modern debate. New Haven, CT: Yale University Press.

Ahmed, Sara. 2000. Strange encounters: embodied others in post-coloniality. London: Routledge.

Ahmed, Sara. 2007. 'A phenomenology of whiteness.' Feminist Theory, 8(2): 149-168. DOI: https://doi.org/10.1177/1464700107078139.

Aink (n.d.), 'Ganja Sangat Mungkin Legal Di Aceh', Accessed 12 April 2017.https://aink420.word-press.com/ganja-sangat-mungkin-legal-di-aceh /?_e_pi_=7\%2CPAGE_ID10\%2C3533090048.

Aiyub, Azhari. 2011. 'Saya Azhari, saya punker: apa ada masalah besar?' Accessed 9 January 2014. http://www.acehkita.com/berita/saya-azhari-saya -punker-apa-ada-masalah-besar/.

Al-Ali, Nadje, Cynthia Enloe and Nicola Pratt. 2008. What kind of liberation? Women and the occupation of Iraq. Berkeley, CA: University of California Press.

Alfian, Teuku Ibrahim. 2006. 'Aceh and the Holy War (Prang Sabil).' In Verandah of violence: the background to the Aceh problem, edited by Anthony Reid, 109-120. Singapore: Singapore University Press.

Anderson, Benedict R. O'G. 1999. 'Indonesian nationalism today and in the future.' Indonesia, 67(April): 1-11. DOI: https://doi.org/10.2307/3351374.

Anon. 2011. 'Punk rockers sent to rehab in Indonesian province.' Tribune Business News, 14 December.

Anon. 2013a. 'Punk keroyok pengunjung Rex.' Serambi Indonesia, 22 November. Accessed 18 August 2020. https://aceh.tribunnews.com/2013 /11/22/punk-keroyok-pengunjung-rex.

Anon. 2013b. 'Tak tahu anaknya jadi punk.' Serambi Indonesia, 22 November. Accessed 29 November 2016. http://aceh.tribunnews.com/2013/11/22/tak -tahu-anaknya-jadi-punk.

Antara News. 2015. 'Korban konflik Aceh peroleh buku nikah gratis.' Antara News, 26 May. Accessed 27 November 2019. https://aceh.antaranews.com /berita/24941/korban-konflik-aceh-peroleh-buku-nikah-gratis.

Arivia, Gadis and Abby Gina. 2015. 'Culture, sex and religion: a review of temporary marriages in Cisarua and Jakarta.' Jurnal Perempuan, 3(1): 23-30.

Asad, Talal. 2003. Formations of the secular: Christianity, Islam, modernity. Stanford, CA: Stanford University Press.

Aspinall, Edward. 2003. 'Modernity, history, and ethnicity' In Autonomy and disintegration in Indonesia, edited by Harry Aveling and Damien Kingsbury, 128-147. London: Routledge Curzon.

Aspinall, Edward. 2008. Peace without justice? The Helsinki peace process in Aceh. Geneva: Center for Humanitarian Dialogue. 
Aspinall, Edward. 2009a. 'Combatants to contractors: the political economy of peace in Aceh.' Indonesia, 87(April): 1-34. DOI: https://doi.org/10.1080/14 678802.2019.1705071.

Aspinall, Edward. 2009b. Islam and nation: separatist rebellion in Aceh, Indonesia. Stanford, CA: Stanford University Press.

Aspinall, Edward and Gerry van Klinken, eds. 2010. The state and illegality in Indonesia. Leiden: KITLV Press.

Assyadath, Ali. 2015. 'Jejak freemasonry di meuligoe Wali Nanggroe.' Accessed 10 February 2017. http://www.kompasiana.com/assyadath.ali/jejak-free masonry-di-meuligoe-wali-nanggroe_55282451f17e61fb1d8b4609.

Aysha, Emad El-Din. 2006. 'Foucault's Iran and Islamic identity politics beyond civilizational clashes, external and internal.' International Studies Perspectives, 7(4): 377-394. DOI: https://doi.org/10.1111/j.1528-3585.2006 .00260.x.

Ayubi, Zahra. 2019a. Gendered morality: classical Islamic ethics of the self, family, and society. New York, NY: Columbia University Press.

Ayubi, Zahra. 2019b. 'Rearing gendered souls: childhood and the making of Muslim manhood in pre-modern Islamic ethics.' Journal of the American Academy of Religion, 87(4): 1178-1208. DOI: https://doi.org/10.1093/jaarel /lfz072.

Azra, Azyumardi. 2000. 'The Islamic factor in post-Soeharto Indonesia.' In Indonesia in transition: social aspects of reformasi and crisis, edited by Chris Manning and Peter van Diermen, 309-318. London: Zed Books.

Badan Perencanaan Pembangunan Daerah Kota Banda Aceh. 2016. Statistik Banda Aceh 2016. Accessed 18 August 2020. https://bandaacehkota.bps .go.id/publication/2016/07/15/122bd1e7b63e35024e62c60e/kota-banda -aceh-dalam-angka-2016.html.

Baden, Sally and Anne Marie Goetz. 1997. 'Who needs [sex] when you can have [gender]? Conflicting discourses on gender at Beijing.' Feminist Review, 56(summer): 3-25. https://www.jstor.org/stable/1395814.

Bakti, Andi Faisal. 2005. 'Islam and modernity: Nurcholish Madjid's interpretation of civil society, pluralism, secularization, and democracy.' Asian Journal of Social Science, 33(3): 486-505. DOI: https://doi .org/10.1163/156853105775013634.

Bali, Maha (@Bali_Maha).2017a. 'Here is what I would have said about Unbearable whiteness of the digital at \#2017asa if I could be there ...' Accessed 20 July 2020. https://t.co/890BNUB53v.

Bali, Maha. 2017b. 'Serendipitous crashing: successful connecting \#disruptingdh.' Accessed 11 January 2018. https://blog.mahabali.me/educational -technology-2/serendipitous-crashing-successful-connecting-disruptingdh/

Banda Aceh Tourism. 2015. 'Dutch water tower in Kutaradja.' Accessed 14 November 2018. https://www.bandaacehtourism.com/en/places/dutch -water-tower-in-kutaradja/\#.W-vutydoQUF. 
Bangstad, Sindre. 2011. 'Saba Mahmood and anthropological feminism after virtue.' Theory, Culture \& Society, 28(3): 28-54. DOI: https://doi .org/10.1177/0263276410396914.

Barker, Joshua. 2009. 'Negara beling: street-level authority in an Indonesian slum.' In States of authority: state in society in Indonesia, edited by Gerry van Klinken and Joshua Barker, 47-72. Ithaca, NY: SEAP Publications.

Barlas, Asma. 2002. 'Believing women' in Islam: unreading patriarchal interpretations of the Quran. Austin, TX: University of Texas Press.

Barlas, Asma. 2008. 'Engaging Islamic feminism: provincialization feminism as a master narrative.' In Islamic feminism: current perspectives, edited by Anitta Kynsilehto, 15-23. Tampere: Juvenes Print. Tampere Peace Research Institute Occasional Paper No. 96.

Basel Action Network. 2019. 'Report on fate of re-exports of seized illegal imports of waste from the USA to Indonesia.' Accessed 30 October 2019. http://wiki.ban.org/images/7/7f/Report_USContainer_Re-exports _Indonesia.pdf.

Beazley, Harriot. 2003. 'Voices from the margins: street children's subcultures in Indonesia.' Children's Geographies, 1(2): 181-200. DOI: https://doi .org/10.1080/14733280302198.

Bedford, Kate. 2007. 'The imperative of male inclusion: how institutional context influences World Bank gender policy.' International Feminist Journal of Politics, 9(3): 289-311. DOI: https://doi.org/10.1080/14616740701438200.

Bedford, Kate. 2009. Developing partnerships: gender, sexuality, and the reformed World Bank. Minneapolis, MN: University of Minnesota Press.

Berlant, Lauren. 1995. 'Live sex acts (parental advisory: explicit material).' Feminist Studies, 21(2): 379-404. DOI: https://doi.org/10.2307/3178273.

Bertrand, Sarah. 2018. 'Can the subaltern securitize? Postcolonial perspectives on securitization theory and its critics.' European Journal of International Security, 3(3): 281-299. DOI: https://doi.org/10.1017/eis.2018.3.

Bhambra, Gurminder K. 2014. Connected sociologies. 1st edn. London: Bloomsbury Academic.

Bhambra, Gurminder K. 2015. 'Whither Europe?' Interventions: International Journal of Postcoloninal Studies, 18(2): 187-202. DOI: https://doi.org/10.10 80/1369801X.2015.1106964.

Bhambra, Gurminder K., Dalia Gebrial and Kerem Nişancioğlu, eds. 2018. Decolonising the university. London: Pluto Press.

Biagini, Erika. 2020. 'Islamist women's feminist subjectivities in (r)evolution: the Egyptian Muslim sisterhood in the aftermath of the Arab uprisings.' International Feminist Journal of Politics, 22(3): 382-402. DOI: https://doi .org/10.1080/14616742.2019.1680304.

Biehl, João and Peter Locke. 2010. 'Deleuze and the anthropology of becoming.' Current Anthropology, 51(3):317-351.DOI:https://doi.org/10.1086/651466.

Blackburn, Susan. 2004a. 'How do women influence political Islam in Indonesia?’ Accessed 20 July 2020. https://en.qantara.de/content/susan-blackburn -how-do-women-influence-political-islam-in-indonesia. 
Blackburn, Susan. 2004b. Women and the state in modern Indonesia. Cambridge: Cambridge University Press.

Blackwood, Evelyn. 2008. 'Transnational discourses and circuits of queer knowledge in Indonesia.' GLQ: A Journal of Lesbian and Gay Studies, 14(4): 481-507. DOI: https://doi.org/10.1215/10642684-2008-002.

Blackwood, Evelyn. 2011. Tombois \& femmes: defying gender labels in Indonesia. Jakarta: Godown Lontar.

Boellstorff, Tom. 2004. 'The emergence of political homophobia in Indonesia: masculinity and national belonging.' Ethnos: Journal of Anthropology, 69(4): 465-486. DOI: https://doi.org/10.1080/0014184042000302308.

Boellstorff, Tom. 2005a. 'Between religion and desire: being Muslim and gay in Indonesia.' American Anthropology, 107(4): 575-585. DOI: https:/doi .org/10.1525/aa.2005.107.4.575.

Boellstorff, Tom. 2005b. The gay archipelago: sexuality and nation in Indonesia. Oxford: Princeton University Press.

Boellstorff, Tom. 2014. 'Lessons from the notion of "moral terrorism." In Feelings at the margins: dealing with violence, stigma and isolation in Indonesia, edited by Thomas Stodulka and Birgitt Röttger-Rössler, 148-158. Frankfurt: Campus Verlag.

Boomgaard, Peter. 2012. 'Male-male sex, bestiality and incest in the earlymodern Indonesian archipelago: perceptions and penalties.' In Sexual Diversity in Asia, c. 600-1950, edited by Raquel A. Reyes and William G. Clarence-Smith, 141-160. London: Routledge.

Bowen, John R. 1997. 'Modern intentions: reshaping subjectivities in an Indonesian Muslim society.' In Islam in an era of nation-states: politics and religious renewal in Muslim Southeast Asia, edited by Robert W. Hefner and Patricia Horvatich, 157-181. Honolulu, HI: University of Hawai'i Press.

Bracke, Sarah. 2016. 'Bouncing back: vulnerability and resistance in times of resilience.' In Vulnerability in resistance, edited by Judith Butler, Zeynep Gambetti and Leticia Sabsay, 52-75. Durham, NC: Duke University Press.

Bradshaw, Sarah. 2013. Gender, development and disasters. Cheltenham: Edward Elgar.

Braithwaite, John and Bina D'Costa. 2018. Cascades of violence: war, crime and peacebuilding across South Asia. Canberra: Australian National University Press.

Braun, Bruce and Sarah J. Whatmore, eds. 2010. Political matter: technoscience, democracy, and public life. Minneapolis, MN: University of Minnesota Press.

Brunila, Kristiina and Kristiina Hannukainen. 2017. 'Academic researchers on the project market in the ethos of knowledge capitalism.' European Educational Research Journal, 16(6): 907-920. DOI: https://doi.org/10.1177 /1474904116685100.

Bunch, Charlotte and Susana Fried. 1996. 'Beijing ‘95: moving women’s human rights from margin to center.' Signs: Journal of Women in Culture and Society, 22(1): 200-204. https://www.jstor.org/stable/3175048. 
Bustaman, Ahmad Kamaruzzaman. 2011. Acehnologi. Banda Aceh: Bandar Publishing.

Butler, Judith. 2004. Undoing gender. Oxford: Routledge.

Butler, Judith. 2006. 'Afterword.' In Bodily citations: religion and Judith Butler, edited by Ellen T. Armour and Susan M. St. Ville, 276-291. New York, NY: Columbia University Press.

Campaign Brief Asia. 2015. 'Real-life heroes show the goodness of life in new campaign for AQUA via Y\&R Group Indonesia.' Accessed 14 November. http://www.campaignbrief.com/asia/2015/08/real-life-heroes-show-the -good.html.

Casas-Cortés, Mariá Isabel, Michal Osterweil, and Dana E. Powell. 2008. 'Blurring Boundaries: Recognizing Knowledge-Practices in the Study of Social Movements.' Anthropological Quarterly, 81(1): 17-58. DOI: https:// doi.org/10.1353/anq.2008.0006.

Chakrabarty, Dipesh. 2002. Habitations of modernity: essays in the wake of subaltern studies. Chicago, IL: University of Chicago Press.

Chakrabarty, Dipesh. 2012. 'Postcolonial studies and the challenge of climate change.' New Literary History, 43(1): 1-18. DOI: https://doi.org/10.1353 /nlh.2012.0007.

Chandler, David. 2015. 'A world without causation: big data and the coming of age of posthumanism.' Millenium: Journal of International Studies, 43(3): 833-851. DOI: https://doi.org/10.1177/0305829815576817.

Chaudhary, Torunn Wimpelmann, Orzala Ashraf Nemat and Astri Suhrke. 2011. 'Promoting women's rights in Afghanistan: the ambiguous footprint of the West.' In A liberal peace? The problems and practices of peacebuilding, edited by Susanna Campbell, David Chandler and Meera Sabaratnam, 106-120. London: Zed Books.

Christensen, Karla. 2010. 'Kids' rock!'. Accessed 16 June 2014. http://www.asla .org/ppn/Article.aspx?id=26214.

Citra Nusa Advertising. 2014. 'TVC Cleo versi galon kemasan baru.' Accessed 6 December 2019. https://www.youtube.com/watch?v=WLhkdWfMC5I.

Clasen, Thomas and Lucy Smith. 2005. 'The drinking water response to the Indian Ocean tsunami, including the role of household water treatment.' In Water, sanitation and health protection of the human environment. Geneva: World Health Organization.

Connell, R. W. and James W. Messerschmidt. 2005. 'Hegemonic masculinity: rethinking the concept.' Gender \& Society, 19(6): 829-859. DOI: https://doi .org/10.1177/0891243205278639.

Connell, Raewyn. 2014. 'Margin becoming centre: for a world-centred rethinking of masculinities.' NORMA, 9(4): 217-231. DOI: https://doi.org/10.1080 /18902138.2014.934078.

Connell, Raewyn. 2016. 'Decolonising the curriculum.' Accessed in 8 January 2018. http://www.raewynconnell.net/2016/10/decolonising-curriculum.html. 
Connell, Raewyn, Fran Collyer, João Maia and Robert Morrell. 2017a. 'Toward a global sociology of knowledge: post-colonial realities and intellectual practices.' International Sociology, 32(1): 21-37. DOI: https://doi .org/10.1177/0268580916676913.

Connell, Raewyn, Rebecca Pearse, Fran Collyer, João Maia and Robert Morrell. 2017b. 'Re-making the global economy of knowledge: do new fields of research change the structure of North-South relations?' British Journal of Sociology. DOI: https://doi.org/10.1111/1468-4446.12294.

Coppens, Laura. 2012. 'Stories from the Margins: Collaborative Filmmaking and Auto-Ethnography as Tools for Lgbt Activism in Indonesia.' Journal des antropologues 2012(130-131): 131-59.

Coppens, Laura. 2013. 'The Question of Authorship in the Collaborative Film Project Anak-Anak Srikandi (Children of Srikandi).' Tsantsa 18, (May 2013): 99-103.

Cornwall, Andrea. 2017. 'Introduction: masculinities under neoliberalism.' In Masculinity under neoliberalism, edited by Andrea Cornwall, Frank G. Karioris and Nancy Lindisfarne. London: Zed Books (e-book).

Dahlman, Carl T. 2011. 'Breaking Iraq: reconstruction as war.' In Reconstructing conflict: integrating war and post-war geographies, edited by Scott Kirsch and Colin Flint, 179-202. Surrey: Ashgate.

Daly, Patrick, Michael Feener, Marjaana Jauhola and Craig Thorburn. 2016. 'Blueprints for change in post-tsunami Aceh, Indonesia.' In Rebuilding Asia following natural disasters: approaches to reconstruction in the Asia-Pacific region, edited by Patrick Daly and Michael Feener, 181-209. Cambridge: Cambridge University Press.

D'Costa, Bina. 2006. 'Marginalized identity: new frontiers of research of IR?' In Feminist methodologies for international relations, edited by Brooke A. Ackerly, Maria Stern and Jacqui True, 129-152. Cambridge: Cambridge University Press.

Deep, Lara. 2015. 'Thinking piety and the everyday together: a response to Fadil and Fernando.' HAU: Journal of Ethnographic Theory, 5(2): 93-96.

de Jong, Joop. 2011. 'The Dutch golden age and globalization: history and heritage, legacies and contestations.' Macalester International, 27: article 7. https://digitalcommons.macalester.edu/macintl/vol27/iss1/7.

Djohar, Zubaidah. 2015. Building a boat in paradise. Poem collection.Depok: Komodo Books.

Djohar, Zubaidah, ed. 2019. Dalam keriput yang tak usang: suara pemuda dan jalan panjang perdamaian Aceh. Lhokseumawe: UNIMAL Press.

Djohar, Zubaidah, ed. 2020. Bisu yang bersuara. Banda Aceh: RPuK.

Donaghey, Jim. 2015. “'Shariah don't like it ...?” Punk and religion in Indonesia.' Punk \& Post Punk, 4(1):29-52. DOI: https://doi.org/10.1386/punk.4.1.29_1. Donaghey, Jim. 2017. 'Punk Indonesia: a brief introduction.' Punk \& Post Punk, 6(2): 181-187. 
Donaghey, Jim and Marjaana Jauhola. 2017. 'Researching "Punk Indonesia" - interview with Marjaana Jauhola by Jim Donaghey for the special issue “Researching Punk Indonesia”. Accessed 20 August 2020. https://blogs .helsinki.fi/marjaanajauhola/files/2017/08/donagheyjauhola2017.pdf.

Dreamlight World Media. n.d. Accessed 12 August 2020 https://dreamlight worldmedia.com/\#0.

Drwiega, Yuyun Ismawati and Mochamad Adi Septiono. 2019. Plastic waste trade in Indonesia country update report. Jakarta: Prigi Arisandi, Ecoton Lee Bell, IPEN.

Dunn, Kevin. 2016. Global punk: resistance and rebellion in everyday life. New York, NY: Bloomsbury.

Duriesmith, David. 2015. "Nothing is clear now": negotiating equality and colonialism through the lives of twelve Acehnese men.' In Engaging men in building gender equality, edited by Richard Howson and Michael Flood, 135-143. Newcastle upon Tyne: Cambridge Scholars Publishing.

Dzulkarnain, Iskandar. 2006. 'Perilaku homoseksual di pondok pesantren.' Unpublished thesis, Sekolah Pascasarjana. Universitas Gajah Mada.

Dzulkarnain, Iskandar. 2009. 'Implikasi globalisasi seksualitas terhadap kebudayaan lokal Madura: studi tentang perilaku homoseksual di pondok pesantren.' Dimensi, 1(1).

Effendy, Bahtiar. 2003. Islam and the state in Indonesia. Singapore: Institute of Southeast Asian Studies.

Elliston, Deborah A. 2000. 'Geographies of gender and politics: the place of difference in Polynesian nationalism.' Cultural Anthropology, 15(2): 171-216. DOI: https://doi.org/10.1525/can.2000.15.2.171.

Eng, David L., Judith Halberstam, and José Esteban Muñoz. 2005. 'Introduction: What's Queer About Queer Studies Now?'. Social Text, 23(3-4): 1-17.

Engebretsen, Elisabeth L. 2014. Queer women in urban China: an ethnography. New York, NY: Routledge.

Enria, Luisa. 2017. "I must stand like a man": masculinity in crisis in postwar Sierra Leone.' In Masculinities under neoliberalism, edited by Andrea Cornwall, Frank G. Karioris and Nancy Lindisfarne. London: Zed Books (e-book).

Ezekilov, Jossif. 2017. 'Gender "men-streaming” CVE: countering violence extremism by addressing masculinities issues.' Reconsidering Development, 5(1). https://pubs.lib.umn.edu/index.php/reconsidering/article/view/908.

Fadil, Nadia and Mayanthi Fernando. 2015. 'Rediscovering the "everyday" Muslim: notes on an anthropological divide.' HAU: Journal of Ethnographic Theory, 5(2): 59-88. DOI: https://doi.org/10.14318/hau5.2.005.

Fan, Lilianne. 2006. 'The struggles for land rights in post-tsunami and postconflict Aceh, Indonesia.' Land Policies and Legal Empowerment of the Poor 2-3 November 2006, World Bank.

Fealy, Greg and Sally White, eds. 2008. Expressing Islam: religious politics in Indonesia. Singapore: ISEAS Publishing. 
Feener, Michael. 2013. Sharia and social engineering: the implementation of Islamic law in contemporary Aceh, Indonesia. Oxford: Oxford University Press.

Field, Syd. 2005 [1979]. Screenplay: the foundations of screenwriting. New York, NY: Delta Book.

Fiscella, Anthony T. 2012. 'From Muslim punks to taqwacore: an incomplete history of punk Islam.' Contemporary Islam, 6(3): 255-281. DOI: https:// doi.org/10.1007/s11562-012-0225-8.

Fitzpatrick, Daniel. 2008. 'Housing for the landless: resettlement in tsunamiaffected Aceh, Indonesia, Asia Research Institute, Aceh Working Paper 1. Singapore: National University of Singapore.

Fitzpatrick, Daniel. 2012. 'Between custom and law: protecting the property rights of women after the tsunami in Aceh.' In From the ground up: perspectives on post-tsunami and post-conflict Aceh, edited by Patrick Daly, Michael R. Feener and Anthony Reid, 114-131. Singapore: Institute of Southeast Asian Studies.

Foucault, Michel. 1998 [1976] [1978]. The will to knowledge: the history of sexuality. Volume I. London: Penguin Books.

Foucault, Michel. 2003. Society must be defended. Lectures at the College de France 1975-76. New York, NY: Picador.

Fulu, Emma. 2014. Domestic violence in Asia: globalization, gender and Islam in the Maldives. London: Routledge.

Fulu, Emma. n.d. 'Masculinities within post-conflict Aceh and its impacts on violence against women.' Unpublished draft.

Fulu, Emma, Xian Warner, Stephanie Miedema, Rachel Jewkes, Tim Roselli and James Lang. 2013. Why do some men use violence against women and how can we prevent it? Bangkok: UNDP, UN Population Fund, UN Women and UNV.

Gallop, Annabel Teh. 2011. 'Gold, silver and lapis lazuli: royal letters from Aceh in the seventeenth century.' In Mapping the Acehnese past, edited by Michael Feener, Patrick Daly and Anthony Reid, 105-140. Leiden: KITLV Press.

Gayatri, B. J. D. 1996. 'Indonesian lesbians writing their own script: issues of feminism and sexuality.' In Amazon to Zami: towards a global lesbian feminism, edited by Monika Reinfelder, 86-97. London: Cassell.

Gobo, Giampietro. 2011. 'Glocalizing methodology? The encounter between local methodologies.' International Journal of Social Research Methodology, 14(6): 417-437. DOI: https://doi.org/https://doi.org/10.1080/13645579.201 1.611379 .

Gray, Mary. 2009. Out in the country: youth, media, and queer visibility in rural America. New York, NY: New York University Press.

Grayman, Jesse Hession. 2012. 'Humanitarian encounters in post-conflict Aceh, Indonesia.' PhD, Department of Anthropology, Harvard University.

Griffiths, Mark. 2016. 'From heterogeneous worlds: Western privilege, class and positionality in the South.' Area, 48(3): 1-7. DOI: https://doi.org/10.1111 /area.12277. 
Grossmann, Kristina. 2012. 'Women as change agents in the transformation process in Aceh, Indonesia.' In Women and politics in Asia: a springboard for democracy?, edited by Andrea Fleschenberg and Claudia Derichs, 97-122. Singapore: Institute of Southeast Asian Studies.

Grossmann, Kristina. 2013. Gender, Islam, aktivismus: handlungsräume muslimischer aktivistinnen nach dem tsunami in Aceh. Berlin: Regiospectra.

Grossmann, Kristina. 2014. 'Muslim female activists and Sharia in Indonesia: scopes of acting in national and international perspectives.' Review of Indonesian and Malay Affairs, 48(1): 95-126.

Grossmann, Kristina. 2015. 'Women's rights activists and the drafting process of the Islamic Criminal Law Code (Qanun Jinayat).' In Islam and the limits of the state: reconfigurations of practice, community and authority in contemporary Aceh, edited by Michael Feener, David Kloos and Annemarie Samuels, 87-117. Leiden: Brill.

Grosz, Elizabeth. 2005. Time travels: feminism, nature, power. Crows Nest: Allen \& Unwin.

Gubernur Provinsi Nanggroe Aceh Darussalam. 2007. Peraturan Gubernur NAD nomor 21 tahun 2007 tentang Rencana Pembangunan Jangka Mengunah Provinsi NAD 2007-2012 [Governor's Regulation number 21 year 2007 on the Mid-Term Development Plan for the years 2007-2012].

Gupta, Sundeep K., Astrid Suantio, Alicia Gray, Endang Widyastuti, Neena Jain, Reineke Rolos, Robert M. Hoekstra and Rob Quick. 2007. 'Factors associated with e. coli contamination of household drinking water among tsunami and earthquake survivors, Indonesia.' American Journal of Tropical Medicine and Hygiene, 76(6): 1158-1162. DOI: https://doi.org/10.4269 /ajtmh.2007.76.1158.

Habadaily. 2016. 'Pedagang mie Peunayong marahi Illiza soal sidak.' 18 August 2020. https://habadaily.com/news/7317/pedagang-mie-peunayong-marahi -illiza-soal-sidak.html.

Hadiz, Vedi R. 2016. Islamic populism in Indonesia and the Middle East. Cambridge: Cambridge University Press.

Hagen, Jamie J. 2016. 'Queering women, peace and security'. International Affairs, 92(2): 313-332. DOI: https://doi.org/10.1111/1468-2346.12551.

Hagen, Jamie J. 2017. 'Queering women, peace and security in Colombia.' Critical Studies on Security, 5(1): 125-129. DOI: https://doi.org/10.1080 /21624887.2017.1294835.

Halberstam, Judith. 2005. In a queer time \& place: transgender bodies, subcultural lives. London: New York University Press.

Hall, Stuart. 2017. Familiar stranger: a life between two islands. London: Allen Lane.

Harding, Sandra, ed. 2004. The feminist standpoint theory reader: intellectual o political controversies. London: Routledge.

Harding, Sandra. 2008. Sciences from below: feminisms, postcolonialities, and modernities. Durham, NC: Duke University Press. 
Hardon, Anita, Nurul Ilmi Idrus and Takeo David Hymans. 2013. 'Chemical sexualities: the use of pharmaceutical and cosmetic products by youth in South Sulawesi, Indonesia.' Reproductive Health Matters, 21(41): 214-224. DOI: https://doi.org/10.1016/S0968-8080(13)41709-3.

Hardon, Anita and Takeo David Hymans. 2014. 'Ethnographies of youth drug use in Asia.' International Journal of Drug Policy, 25(4): 749-754. DOI: https://doi.org/10.1016/j.drugpo.2014.06.009.

Harman, Sophie. 2019. Seeing politics: film, visual method, and international relations. Montreal: McGill-Queen's University Press.

Harun, Ramli. 1982. Hikayat Tajul Muluk. Jakarta: Departemen Pendidikan dan Kebudayaan.

Hawkins, G., E. Potter and K. Race. 2015. Plastic water: the social and material life of bottled water. Cambridge, MA: MIT Press.

Hill, Kai T. and Jullya Vigneshvara. 2007. 'Indonesia: Aceh park, a symbol of recovery, renewal and healing.' Accessed 11 February 2020. https://reliefweb .int/report/indonesia/indonesia-aceh-park-symbol-recovery-renewal-and -healing.

Hill, Peter. 2013. “The civil” and "the secular" in contemporary Arab politics.' Accessed 20 April 2014. http://muftah.org/the-civil-and-the-secular-in -contemporary-arab-politics/\#.U1McoseoV5U.

Hizb ut Tahrir. 2015. 'Women and Shariah: separating fact from fiction 2015 conference speech videos.' Closed Facebook group.

Hoesterey, James B. and Marshall Clark. 2012. 'Film Islami: gender, piety and pop culture in post-authoritarian Indonesia.' Asian Studies Review, 36(2): 207-226. DOI: https://doi.org/10.1080/10357823.2012.685925.

Hongisto, Ilona. 2015. Soul of the documentary: framing, expression, ethics. Amsterdam: Amsterdam University Press.

hooks, bell. 2003. 'The oppositional gaze: black female spectators.' In The feminism and visual culture reader, edited by Amelia Jones, 94-105. London: Routledge.

Hurgronje, C. Snouck. 1906. The Achehnese, Volume I. Leiden: Brill.

Ibrahimhakkioglu, Fulden. 2012. 'Embodied affective experience in Saba Mahmood's politics of piety: reformulating agency for an inclusive transnational feminism.' APA Newsletters, 12(1): 14-19.

Ichwan, Moch Nur. 2007. 'The politics of Shariatization: central governmental and regional discourse of Shari'a implementation in Aceh.' In Islamic law in contemporary Indonesia: ideas and institutions, edited by Michael Feener and Mark Cammack, 193-215. Cambridge, MA: Harvard University Press. Ichwan, Moch Nur. 2011. 'Official ulema and the politics of re-Islamization: the Majelis Permusyawaratan Ulama, sharī 'atization and contested authority in post-New Order Aceh.' Journal of Islamic Studies, 22(2): 183-214. DOI: https://doi.org/10.1093/jis/etr026.

Ichwan, Moch Nur. 2016. 'Neo-Sufism, shariatism, and ulama politics: Abuya Shaykh Amran Waly and the tauhid-tasawuf movement in Aceh.' In Islam, 
politics and change: the Indonesian experience after the fall of Suharto, edited by Kees van Dijk and Nico J. G. Kaptein, 221-246. Leiden: Leiden University Press.

Idria, Reza. 2013. 'Cultural resistance to Shariatism in Aceh.' In Regime change, democracy and Islam: the case of Indonesia, 180-201. Leiden: University of Leiden.

Idria, Reza. 2015. 'Muslim punks and state Shari'a.' In Islam and the limits of the state: reconfigurations of practice, edited by Michael Feener, David Kloos and Annemarie Samuels, 166-184. Leiden: Brill.

Inhorn, Marcia C. 2012. The new Arab man: emergent masculinities, technologies, and Islam in the Middle East. Princeton, NJ: Princeton University Press.

Irkhami, Nafis. 2014. 'The economic-political concept of Hizbut Tahrir Indonesia: reflection on the early Islamic thoughts.' IJIMS, Indonesian Journal of Islam and Muslim Societies, 4(1): 105-134. DOI: https://doi. org/10.18326/ijims.v4i1.105-134.

Ismail, Salwa. 2006. Political life in Cairo's new quarters. Minneapolis, MN: University of Minnesota Press.

Jackson, Michael. 2007. 'Intersubjective ambiguities.' Medische Antropologie, 19(1): 147-161.

Jaffee, Daniel and Soren Newman. 2013. 'A more perfect commodity: bottled water, global accumulation, and local contestation.' Rural Sociology, 78(1): 1-28. DOI: https://doi.org/10.1111/j.1549-0831.2012.00095.x.

Japan International Cooperation Agency, Provincial Government of Nanggroe Aceh Darussalam, Banda Aceh City, and Rehabilitation and Reconstruction Agency. 2006. 'Additional study for URRP for BAC.' Accessed 14 November 2018. http://open_jicareport.jica.go.jp/pdf/11822590_07.pdf.

Jauhola, Marjaana. 2010. 'Building back better? Negotiating normative boundaries of gender mainstreaming and post-tsunami reconstruction in Nanggroe Aceh Darussalam, Indonesia.' Review of International Studies, 36(1): 29-50. DOI: https://doi.org/10.1017/S0260210509990490.

Jauhola, Marjaana. 2011. “The girl child of today is the woman of tomorrow”: fantasizing the adolescent girl as the future hope in post-tsunami reconstruction efforts in Aceh, Indonesia.' Rhizomes, 22. Accessed 20 July 2020. http://www.rhizomes.net/issue22/jauhola/index.html.

Jauhola, Marjaana. 2012. "Natural” sex difference? Negotiating the meanings of sex, gender and kodrat through gender equality discourse in Aceh, Indonesia.' Intersections: Gender and Sexuality in Asia and the Pacific, 28.

Jauhola, Marjaana. 2013. Post-tsunami reconstruction in Indonesia: negotiating normativity through gender mainstreaming initiatives in Aceh. London: Routledge.

Jauhola, Marjaana and Yudi Bolong. 2014. 'The punks of the Tsunami Museum: post-disaster Indonesia (photoessay)'. Planet - The Welsh Internationalist, 215(autumn): 26-35. 
Jauhola, Marjaana. 2015a. 'On “being bored” - street ethnography on emotions in Banda Aceh after the tsunami and conflict.' In Emotions, politics and war, edited by Linda Åhäll and Thomas Gregory, 86-99. London: Routledge.

Jauhola, Marjaana. 2015b. 'Scraps of home: social and vernacular memory and politics of disaster humanitarianism in Aceh, Indonesia.' Asian Journal of Social Science, 43(6): 738-759. https://doi.org/10.1163/15685314 -04306005 .

Jauhola, Marjaana. 2016. 'Decolonizing branded peacebuilding: abjected women talk back to the Finnish Women, Peace and Security agenda.' International Affairs, 92(2): 333-351.

Jauhola, Marjaana. 2017. 'Visual ethnographic encounters and silence in postconflict city of Banda Aceh, Indonesia.' In Experiences with violent research and researching violence, edited by Althea-Maria Rivas and Brendan Browne, 179-184. Bristol: Polity Press.

Jauhola, Marjaana. 2020. 'Tindakan La RêVerie Untuk Keadilan Buta.' In Bisu yang bersuara, edited by Zubaidah Djohar, xix-xxiii. Banda Aceh: RPuK.

Jauhola, Marjaana and Yudi Bolong. 2017. 'A.C.A.B. - studying up the rule of law in Banda Aceh, Indonesia.' Punk \& Post Punk, 6(2): 213-232.

Jayasankar, K. P. and Anjali Monteiro. 2016. A fly in the curry: independent documentary film in India. New Delhi: SAGE.

Jinnmonkey. 2012. 'Aceh punks arrested \& sent to re-education camps.' Video file, 10 February. Accessed 9 January 2014. https://www.youtube.com $/$ watch? $\mathrm{v}=6 \mathrm{HS} 8 \mathrm{cci} 2 \mathrm{~T} 0 \mathrm{M}$.

Jones, Balawyn. 2019. 'Challenging syariah.' Accessed 13 November 2019. https://www.insideindonesia.org/challenging-syariah.

Jones, Branwen Grufydd, ed. 2009. Decolonizing international relations. Lanham, MD: Rowman \& Littlefield.

Kammen, Douglas and Katharine McGregor, eds. 2012. The contours of mass violence in Indonesia, 1965-68. Singapore: NUS Press.

Kandiyoti, Deniz. 2007a. 'Between the hammer and the anvil: post-conflict reconstruction, Islam and women's rights.' Third World Quarterly, 28(3): 503-517. DOI: https://doi.org/10.1080/01436590701192603.

Kandiyoti, Deniz. 2007b. 'Old dilemmas or new challenges? The politics of gender and reconstruction in Afghanistan.' Development and Change, 38(2): 169-199. DOI: https://doi.org/10.1111/j.1467-7660.2007.00408.x.

Kandiyoti, Deniz. 2009. 'Islam, modernity and the politics of gender.' In Islam and modernity: key issues and debates, edited by Muhammad Khalid Masud, Armando Salvatore and Martin van Bruinessen, 100-124. Edinburgh: Ediburgh University Press.

Kang, Miliann. 2010. The managed hand: race, gender and the body in beauty service. Berkeley, CA: University of California Press.

Katz, Jonathan Ned. 1990. 'The Invention of Heterosexuality'. Socialist Review 20(1): 7-34. 
Kenway, Jane and Johannah Fahey. 2009. Globalizing the research imagination. London and New York, NY: Routledge.

Keskinen, Suvi and Rikke Andreassen. 2017. 'Developing theoretical perspectives on racialization and migration.' Nordic Journal of Migration Research, 7(2): 64-69. DOI: https://doi.org/10.1515/njmr-2017-0018.

Khaerina, Shabrina Septya and Juneman Abraham. 2014. 'Sexual disorders and right-wing authoritarianism in Indonesian boarding school.' International Journal of Resarch Studies in Psychology, 3(4): 99-109. DOI: https://doi .org/10.5861/ijrsp.2014.870.

Khan, Sher Banu A. L. 2007. 'The jewel affair: the sultanah, her orangkaya and the Dutch foreign envoys.' First International Conference of Aceh and Indian Ocean Studies, 24-26 February 2007, Banda Aceh.

Khan, Sher Banu A. L. 2010. 'The sultanahs of Aceh, 1641-99.' In Aceh: history, politics and culture, edited by Arndt Graf, Susanne Schröter and Edwin Wieringa, 3-25. Singapore: Institute of Southeast Asian Studies.

Khan, Sher Banu A. L. 2017. Sovereign women in a Muslim kingdom: the sultanahs of Aceh, 1641-1699. Singapore: NUS Press.

khanna, akshay. 2016. Sexualness. New Delhi: New Text.

Khatami, Mahmoud. 2003. 'Foucault on the Islamic Revolution of Iran' Journal of Muslim Minority Affairs, 23(1): 121. DOI: https://doi.org/10.1080 /13602000305936.

Kloos, David. 2013. 'Strengthening local leadership. Sharia, customs, and the dynamics of vigilante violence in Aceh.' In Regime change, democracy and Islam: the case of Indonesia, 202-236. Leiden: Universiteit Leiden.

Kloos, David. 2017. Becoming better Muslims: religious authority and ethical improvement in Aceh, Indonesia. Princeton, NJ: Princeton University Press.

Komarulzaman, Ahmad, Jeroen Smits and Eelke de Jong. 2014. 'Clean water, sanitation and diarrhoea in Indonesia: effects of household and community factors.' In NiCE Working Paper 12-105, October 2014. Nijmegen: Nijmegen Center for Economics, Institute for Management Research, Radboud University Nijmegen.

Korf, Benedikt, Shahul Habullah, Pia Hollenbach and Bart Klem. 2010. 'The gift of disaster: the commodification of good intentions in post-tsunami Sri Lanka.' Disasters, 34(s1): S60-S77. DOI: https://doi.org/10.1111/j.1467 -7717.2009.01099.x.

KontraS. 2015. Marsinah 22 Tahun Tanpa Keadilan. Accessed 8 December 2016. http://kontrassurabaya. org/marsinah-22-tahun-tanpa-keadilan/.

Kunz, Rahel, Henri Myrttinen and Wening Udasmoro. 2018. 'Preachers, pirates and peace-building: examining non-violent hegemonic masculinities in Aceh.' Asian Journal of Women's Studies, 24(3): 299-320. DOI: https://doi .org/10.1080/12259276.2018.1495348.

Lamb, Kate. 2011. 'Sharia police arrest "punks" in Indonesia's Aceh.' Accessed 20 July 2020. https://www.voanews.com/east-asia-pacific/sharia-police -arrest-punks-indonesias-aceh. 
Lambek, Michael. 2015. 'Living as if it mattered.' In Four lectures on ethics: anthropological perspectives, edited by Michael Lambek, Veena Das, Didier Fassin and Webb Keane, Lecture 1. Chicago, IL: HAU Books.

Lambek, Michael, Veena Das, Didier Fassin and Webb Keane. 2015. Four lectures on ethics: anthropological perspectives. Chicago, IL: HAU Books.

Landry, Donna and Gerald MacLean. 1996. 'Subaltern talk: interview with editors (1993-94).' In The Spivak reader, edited by Donna Landry and Gerald MacLean, 287-308. London: Routledge.

Lee-Koo, Katrina. 2012. 'Gender at the crossroad of conflict: tsunami and peace in post-2005 Aceh.' Feminist Review 101(101): 59-77. DOI: https://doi .org/10.2307/41495233.

Lee-Koo, Katrina. 2018. 'Gendered state and the emergence of a postconflict, postdisaster semiautonomous state.' In Revisiting gendered states: feminist imaginings of the state in international relations, edited by Swati Parashar, J. Ann Tickner and Jacqui True. New York, NY: Oxford University Press.

Lind, Amy. 2014. “'Out” in international relations: why queer visibility matters.' International Studies Review, 16(4): 601-604. DOI: https://doi.org/10.1111 /misr.12184.

Lindquist, Johan. 2004. 'Veils and ecstasy: negotiating shame in the Indonesian borderlands.' Ethnos: Journal of Anthropology, 69(4): 487-508. DOI: https:// doi.org/10.1080/0014184042000302317.

Lindsey, Tim. 2001. 'The criminal state: premanisme and the new Indonesia.' In Indonesia today: challenges of history, edited by Grayson Lloyd and Shannon L. Smith, 283-297. Lanham, MD: Rowman \& Littlefield.

Loomba, Ania. 1998. Colonialism/postcolonialism. London: Routledge.

Lorde, Audre. 2017. 'Poetry is not a luxory.' In The master's tools will never dismantle the master's house, 1-5. New York, NY: Penguin Random House.

Lugones, Marìa. 2010. 'Toward a Decolonial Feminism.' Hypatia, 25(4): 742-59.

MacKenzie, Megan H. 2012. Female soldiers in Sierra Leone: sex, security, and post-conflict development. New York, NY: New York University Press.

Mahdi, Saiful. 2014. 'City population changes in post-disaster region: a case of post-tsunami Aceh, Indonesia.' In Government and communities: sharing Indonesia's common goals, edited by Mohamad Fahmi, Arief A. Yusuf, Muhamad Purnagunawan, Budy P. Resosudarmo and D. S. Priyarsono, 267-290. Bandung: UNPAD Press.

Mahmood, Saba. 2012 [2005]. Politics of piety: the Islamic revival and the feminist subject. Princeton, NJ: Princeton University Press.

Marhaban, Shadia. 2012. 'The reintegration of ex-combatants in post-war Aceh.' In Post-war security transitions: participatory peacebuilding after asymmetric conflicts, edited by Véronique Dudouet, Hans J. Giessmann and Katrin Planta, 315-336. London: Routledge.

Marshall, Paul. 2018. 'The ambiguities of religious freedom in Indonesia.' Review of Faith \& International Affairs, 16(1): 85-96. DOI: https://doi.org /10.1080/15570274.2018.1433588. 
Martini, Ermina and Marjaana Jauhola. 2014. 'Journeys in Aidland: an autobiographic exploration of resistance to development aid.' Journal of Narrative Politics, 1(1): 76-96. Accessed on 23 April 2015. http://journalofnarrative politics.com/wp-content/uploads/2014/09/JNP-Vol-1-Jahoula-and -Martini1.pdf.

May, Bernhard. 2008. 'The Law on the Governing of Aceh: the way forward or a source of conflicts?' Accord, 20(2008): 42-45.

McCall, Corey. 2013. 'Ambivalent modernities: Foucault's Iranian writings reconsidered.' Foucault Studies, 1(15): 27-51. DOI: https://doi.org/10.22439 /fs.v0i15.3989.

McEwan, Cheryl. 2009. Postcolonialism and development. London: Routledge.

Mehta, Lyla. 2007. 'Whose scarcity? Whose property? The case of water in western India.' Land Use Policy, 24(4): 654-663. DOI: https://doi.org /10.1016/j.landusepol.2006.05.009.

Melvin, Jess. 2013. 'Why not genocide? Anti-Chinese violence in Aceh, 1965-1966.' Journal of Current Southeast Asian Studies, 32(3): 63-91.

Melvin, Jess. 2014. 'Mechanics of mass murder: how the Indonesian military initiated and implemented the Indonesian genocide, the case of Aceh.' PhD Thesis. School of Historical and Philosophical Studies, University of Melbourne.

Miller, Daniel, Elisabetta Costa, Nell Haynes, Tom McDonald, Razvan Nicolescu, Jolynna Sinanan, Juliano Spyer, Shriram Venkatraman and Xinyuan Wang. 2016. How the world changed social media. London: UCL Press.

Miller, Michelle Ann. 2008. 'The conflict in Aceh: context, precursors and catalysts.' Accord, 20: 12-15.

Miller, Michelle Ann. 2009. Rebellion and reform in Indonesia: Jakarta's security and autonomity policies in Aceh. London: Routledge.

Miller, Michelle Ann. 2010. 'The role of Islamic law (Sharia) in post-tsunami reconstruction.' In Post-disaster reconstruction: lessons from Aceh, edited by Matthew Clarke, Ismet Fanany and Sue Kenny, 29-60. London: Earthscan.

Ministry for Foreign Affairs. 2010. 'Peace mediation: Finland's guidelines.' Helsinki: Ministry for Foreign Affairs. Accessed 30 June 2020. https://um .fi/documents/35732/48132/peace_mediation___finland_s_guide lines/1c0f591c-184c-9fc3-e9b2-38be8af0e1d1?t=1525860146706.

Mir-Hosseini, Ziba and Mulki Al-Sharmani. 2015. 'Introduction.' In Men in charge? Rethinking authority in Muslim legal tradition, edited by Ziba Mir-Hosseini and Mulki Al-Sharmani, 1-12. London: Oneworld Publications.

Mir-Hosseini, Ziba and Vanja Hamzić. 2010. Control and sexuality: the revival of zina laws in Muslim contexts. London: Women Living Under Muslim Laws.

Mirzayanto and Yulian Gressando. 2013. 'Gampong Jawa landfill of Banda Aceh: a case study of dumpsite rehabilitation to a sustainable landfill.' Accessed 28 October 2019. https://www.neliti.com/publications/346/gampong-jawa -landfill-of-banda-aceh-a-case-study-of-dumpsite-rehabilitation-to-a. 
Missbach, Antje. 2011. 'Ransacking the field?' Critical Asian Studies, 43(3): 373-398. DOI: https://doi.org/10.1080/14672715.2011.597334.

Mohanty, Chandra Talpade. 1984. 'Under Western eyes: feminist scholarship and colonial discourses.' Boundary 2, 12(3): 333-358.

Mohanty, Chandra Talpade. 2003. “Under Western eyes” revisited: feminist solidarity through anticapitalist struggles.' Signs: Journal of Women in Culture and Society, 28(2): 499-535.

Moore, Lisa Jean and Jefrey Mathias. 2016. 'Embodied knowledge.' In The Blackwell Encyclopedia of Sociology, edited by George Ritzer, 1-3. Blackwell. https://doi.org/10.1002/9781405165518.wbeos0674.

Moran, Leslie, Beverley Skeggs, Paul Tyrer and Karen Corteen. 2001. 'Property, boundary, exclusion: making sense of hetero-violence in safer spaces.' Social \& Cultural Geography, 2(4): 407-420. DOI: https://doi.org /10.1080/14649360127228.

Murrell, Peter. 2013. 'Sin \& sodomy in the Dutch East Indies'. History Today, 63(6): 10-17.

Myrttinen, Henri. 2012. 'Guerrillas, gangsters and contractors: integrating former combatants and its impact on SSR and development in post-conflict societies.' In Back to the roots: security sector reform and development, edited by Albrecht Schnabel and Vanessa Farr, 225-247. Geneva: Geneva Centre for the Democratic Control of Armed Forces.

Myrttinen, Henri, Lana Khattab and Jana Naujoks. 2016. 'Re-thinking hegemonic masculinities in conflict-affected contexts.' Critical Military Studies, 3(2): 103-119. DOI: https://doi.org/10.1080/23337486.2016.1262658.

n.a. 2019. 'Aktivis perempuan Aceh: qanun poligami tidak penting.' Accessed 3 November 2019. https://regional.kompas.com/read/2019/07/07/16061351 /aktivis-perempuan-aceh-qanun-poligami-tidak-penting.

Nasir, Muhammad. 2018. 'Balai kota Banda Aceh didemo, massa tuntut penyelesaian masalah air bersih.' Serambi Indonesia, 26 October. Accessed 20 July 2020. http://aceh.tribunnews.com/2018/10/26/balai-kota-banda -aceh-didemo-massa-tuntut-penyelesaian-masalah-air-bersih.

Nasser-Eddin, Nof, Nour Abu-Assab and Aydan Greatrick. 2018. 'Reconceptualising and contextualising sexual rights in the MENA region: beyond LGBTQI categories.' Gender \& Development, 26(1): 173-189. DOI: https:// doi.org/10.1080/13552074.2018.1429101.

Nasution, Hasyimsyah, Yusnadi and Zahari. 2019. 'Commitment of political communication in the Mayor of Banda Aceh.' Budapest International Research and Critics Institute (BIRCI Journal) Humanities and Social Sciences, 2(1). DOI: https://doi.org/10.33258/birci.v2i1.143.

Nilan, Pam. 2009. 'Contemporary masculinities and young men in Indonesia.' Indonesia \& the Malay World, 37(109): 327-344. DOI: https://doi .org/10.1080/13639810903269318.

Nilsson, Jeanna. 2018. 'Fearing the queer and the war on "indecency": portrayals of LGBT individuals, and the struggle for religious decorum in 
Aceh, Indonesia.' MA thesis, Centre for East and South-East Asian Studies, University of Lund.

Nizar, Muhammad, Irvan Matseh, Erman Munir and V. Waller. 2018. 'The integrating of zero waste principles from national to local regulations: case study of Banda Aceh, Indonesia.' IOP Conference Series: Earth and Environmental Science, 216(1): 1-9. DOI: https://doi.org/10.1088/1755-1315 /216/1/012043.

Nobes, Andy. 2017. 'Must we decolonise Open Access? Perspectives from Francophone Africa' Accessed 18 August 2020. http://journalologik.uk l? $\mathrm{p}=149$.

Noble, Denise. 2017. Decolonizing and feminizing freedom. London: Palgrave Macmillan.

Nordstrom, Carolyn. 1997. A different kind of war story. Philadelphia, PA: University of Pennsylvania Press.

Nurdin, Muhammad Reza. 2015. 'Disaster "caliphatization": Hizbut Tahrir Indonesia, Islamic Aceh, and the Indian Ocean tsunami.' International Journal of Mass Emergencies and Disasters, 33(1): 75-95.

Nurish, Amanah. 2010. 'Women's same-sex relations in Indonesian pesantren.' Gender, Technology and Development, 14(2): 267-277. DOI: https://doi .org/10.1177/097185241001400207.

Nursiti and Mustabsyirah M. Hsein (eds.) 2015. Kiprah perempuan dalam mewujudkan dan memelihara perdamaian di Aceh. Banda Aceh: Pusat Studi Wanita, Universitas Islam Negeri Ar-Raniry Banda Aceh.

Nyanzi, Stella. 2013. 'Dismantling reified African culture through localised homosexualities in Uganda.' Culture, Health \& Sexuality, 15(8): 952-967. DOI: https://doi.org/10.1080/13691058.2013.798684.

Oetomo, Dèdè. 2003 [2001]. Memberi suara pada yang bisu. Yogyakarta: Pusaka Marwa Yogyakarta.

Oikarinen-Jabai, Helena. 2017. “Mulla on kans suomalaisuutta alitajunnassa” somalitaustaisten nuorten näkökulmia suomalaisuuteen.' Lähikuva, 30(4): 38-56. https://doi.org/10.23994/lk.69010

Ong, Aihwa. 2003. Buddha is hiding: refugees, citizenship, the new America. 1st edn. California series in public anthropology. Berkeley, CA: University of California Press.

Ong, Aihwa. 2009. 'On being human and ethical living.' In Globalizaing the research imagination, edited by Jane Kenway and Johannah Fahey, 87-100. London: Routledge.

Ong, Aihwa. 2010. Spirits of resistance and capitalist discipline: factory women in Malaysia. 1st edn. UPCC book collections on Project MUSE. Albany, NY: State University of New York Press.

Ong, Aihwa and Stephen J. Collier. 2005. Global assemblages: technology, politics, and ethics as anthropological problems. Malden, MA: Blackwell.

Onodera, Henri. 2015. 'Being young activist in the late Mubarak era: an ethnography of political engagement in Egypt.' PhD thesis, Faculty of Social Sciences, University of Helsinki. 
Oosterhoff, Jan. 1989. 'Sodomy at sea and at the Cape of Good Hope during the eighteenth century.' Journal of Homosexuality, 16(1-2): 229-235. DOI: https://doi.org/10.1300/J082v16n01_12.

Opel, Andy. 1999. 'Constructing purity: bottled water and the commodification of nature.' Journal of American Culture, 22(4): 67-76. DOI: https://doi .org/10.1111/j.1542-734X.1999.2204_67.x.

Ortner, Sherry B. 1995. 'Resistance and the problem of ethnographic refusal.' Comparative Studies in Society and History, 37(1): 173-193. DOI: https:// doi.org/10.1017/S0010417500019587.

Osman, Mohamed Nawab Mohamed. 2010. 'Reviving the caliphate in the Nusantara: Hizbut TahrirIndonesia's mobilization strategy and its impact in Indonesia. Terrorism and Political Violence, 22(4): 601-622. DOI: https:// doi.org/10.1080/09546553.2010.496317.

Osman, Mohamed Nawab Mohamed. 2018. Hizbut Tahrir Indonesia and political Islam: identity, ideology and religio-political mobilization. London: Routledge.

Pabón-Colón, Jessica Nydia. 2017. 'Writin', breakin', beatboxin': strategically performing "women" in hip-hop.' Signs: Journal of Women in Culture and Society, 43(1): 175-200. DOI: https://doi.org/10.1086/692481.

Pacheco-Vega, Raúl. 2015. 'Agua embotellada en México: de la privatización del suministro a la mercantilización de los recursos hídricos.' Espiral, XXII(63): 221-263. DOI: https://doi.org/10.32870/espiral.v22i63.1671.

Pacheco-Vega, Raúl. 2019a. 'Human right to water and bottled water consumption.' In Water politics: governance, justice and the right to water, edited by Farhana Sultana and Alex Loftus, 113-128. London: Routledge.

Pacheco-Vega, Raúl. 2019b. '(Re)theorizing the politics of bottled water: water insecurity in the context of weak regulatory regimes.' Water, 11(4): 658. DOI: https://doi.org/10.3390/w11040658.

Page, Tiffany. 2017. 'Vulnerable writing as a feminist methodological practice.' Feminist Review, 115(1): 13-29. DOI: https://doi.org/10.1057/s41305-017 -0028-0.

Peletz, Michael G. 2002. Islamic modern: religious courts and cultural politics in Malaysia. Oxford: Princeton University Press.

Pemerintah Aceh. 2013. Qanun Aceh nomor 12 tahun 2013 tentang Rencana Pembangunan Jangka Menengah Aceh tahun 2012-17.

Pemerintah Kota Banda Aceh. 2012. Rencana Pembangunan Jangka Menengah Daerah: Kota Banda Aceh Tahun 2012-2017. Babbeda Banda Aceh.

Pemerintah Kota Banda Aceh. 2016. “'Surga Menanti” di Banda Aceh.' Accessed 14 November 2019. https://bandaacehkota.go.id/berita/5942/surga-men anti-di-banda-aceh-2.html.

Penttinen, Elina. 2013. Joy and international relations: a new methodology. Abingdon: Routledge.

Peterson, V. Spike. 2014. 'Family matters: how queering the intimate queers the international.' International Studies Review, 16(4): 604-608. DOI: https:// doi.org/10.1111/misr.12185. 
Pink, Sarah. 2013. Doing Visual Ethnography. London: SAGE.

Prasetiawan, Teddy, Anindrya Nastiti and Barti Setiani Muntalif. 2017. "Bad" piped water and other perceptual drivers of bottled water consumption in Indonesia.' Wiley Interdisciplinary Reviews: Water, 4(4): e1219. DOI: https:// doi.org/10.1002/wat2.1219.

Puar, Jasbir K. 2007. Terrorist assemblages: homonationalism in queer times. London: Duke University Press.

Puar, Jasbir K. 2018. Terrorist assemblages: homonationalism in queer times. Tenth anniversary expanded edition. Durham, NC: Duke University Press.

Punk Aid. 2012. Punk Aid: Aceh Calling, digital album. Accessed 17 August 2020. https://punkaid.bandcamp.com/album/punk-aid-aceh-calling.

Puumala, Eeva. 2013. 'Politiikan tuntu, mieli ja merkitys: tapahtuva yhteisö ja poliitisen kokemus kehollisissa kohtaamisissa.' Tiede \& Edistys, 38(2): $125-138$.

Raheja, Michelle. 2007. 'Reading Nanook's smile: visual sovereignty, indigenous revisions of ethnography, and Atanarjuat (The fast runner).' American Quarterly, 59(4): 1159-1185. DOI: https://doi.org/10.1353/aq.2007.0083.

Rahimi, Babak. 2006. 'Rahimi on Afary and Anderson, 'Foucault and the Iranian Revolution: gender and the seductions of Islamism.” Accessed 5 May 2016. https://networks.h-net.org/node/6386/reviews/6694/rahimi-afary-and -anderson-foucault-and-iranian-revolution-gender-and.

Rahman, Alf, Shimpei Iwasaki, Stephen Anthony Sutton, Aiko Sakurai and Parmakope. 2019. 'Urban water management issues and challenges after the 2004 Indian Ocean tsunami recovery: lessons learned from Banda Aceh city, Indonesia.' In Urban drought: emerging water challenges in Asia, edited by Bhaswati Ray and Rajib Shaw, 399-412. Singapore: Springer.

Rao, Rahul. 2015. 'Echoes of imperalism in LGBT activism.' In Echoes of Empire: Memory, Identity and the Legacy of Imperialism, edited by Kalypso Nicolaïdis, Berny Sebe and Gabrielle Maas. London: I. B. Tauris.

Rao, Rahul. 2018. 'The state of "queer IR." GLQ: A Journal of Lesbian and Gay Studies, 24(1): 139-149. DOI: https://doi.org/10.1215/10642684-4254531.

Rao, Rahul. 2019. 'One time, many times.' Millennium, 47(2): 299-308. DOI: https://doi.org/10.1177/0305829818801494.

Rao, Rahul. 2020. Out of time: the queer politics of postcoloniality. New York, NY: Oxford University Press.

Rasyidah, Munawiah and Ismiati. 2016. Masculinities in post-conflict Aceh and its impacts on violence against women. Jakarta: Ibnunourhas Publishing.

Reid, Anthony. 2005. An Indonesian frontier: Achenese \& other histories of Sumatra. Singapore: Singapore University Press.

Riches, Gabrielle. 2011. 'Embracing the chaos: mosh pits, extreme metal music and liminality. Journal for Cultural Research, 15(3): 315-332. DOI: https:// doi.org/10.1080/14797585.2011.594588.

Richter-Montpetit, Melanie. 2017. 'Everything you always wanted to know about sex (in IR) but were afraid to ask: the "queer turn" in international relations.' Millenium: Journal of International Studies, 46(2): 220-240. 
Rico, Trinidad. 2016. Constructing destruction: heritage narratives in the tsunami city. New York, NY: Routledge.

Rinaldo, Rachel. 2002. 'Ironic legacy: the New Order and Indonesian women's groups.' Outskirts: Feminisms Along the Edge, 10.

Rinaldo, Rachel. 2013. Mobilizing piety: Islam and feminism in Indonesia. New York, NY: Oxford University Press.

Robinson, Kathryn. 1995. 'Indonesian national identity and the citizen mother.' Communal/Plural, 3: 65-81.

Robinson, Kathryn. 2009. Gender, Islam and democracy in Indonesia. London: Routledge.

Rutazibwa, Olivia U. 2019. 'On babies and bathwater: decolonizing international development studies.' In Decolonization and feminisms in global teaching and learning, edited by Anisa de Jong, Rosalba Icaza and Olivia U. Rutazibwa, 158-180. London: Routledge.

Sabaratnam, Meera. 2017. Decolonizing intervention: international statebuilding in Mozambique. London: Rowman \& Littlefield International.

Sahendra, Tommy. 2011. 'Keceriaan anak punk di Sekolah Polisi Negara' (Youtube video), 26 December. Accessed 18 August 2017. https://www.you tube.com/watch?v=FHz5kj7V-Q8.

Salim, Arskal and Adlin Sila, eds. 2010. Serambi Mekkah yang berubah: views from within. Tangerang: Aech Research Training Institute.

Salvatore, Armando. 2009. 'Tradition and modernity within Islamic civilisation and the West.' In Islam and modernity: key issues and debates, edited by Muhammad Khalid Masud, Armando Salvatore and Martin van Bruinessen, 3-35. Edinburgh: Edinburgn University Press.

Salvatore, Armando and Mark LeVine. 2005. 'Introduction: reconstructing the public sphere in Muslim majority societies.' In Religion, social practice, and contested hegemonies: reconstructing the public sphere in Muslim majority societies, edited by Armando Salvatore and Mark LeVine, 1-26. New York, NY: Palgrave Macmillan.

Samuels, Annemarie. 2016. 'Seeing AIDS in Aceh: sexual moralities and the politics of (in)visibility in reconstruction times.' Indonesia, 101(April): 103-120. DOI: https://doi.org/10.1353/ind.2016.0002

Samuels, Annemarie. 2019. After the tsunami: disaster narratives and the remaking of everyday life in Aceh. Honolulu, HI: University of Hawai'i Press.

Schenk, Christine G. 2019. 'Legal and spatial ordering in Aceh, Indonesia: inscribing the security of female bodies into law. Environment and Planning A: Economy and Space, 51(5): 1128-1144. DOI: https://doi.org /10.1177/0308518x19836119.

Schielke, Samuli. 2012. 'Surfaces of longing: cosmopolitan aspiration and frustration in Egypt.' City \& Society, 24(1): 29-37. https://doi.org/10.1111 /j.1548-744X.2012.01066.x.

Schielke, Samuli. 2015. 'Living with unresolved differences: a reply to Fadil and Fernando.' HAU: Journal of Ethnographic Theory, 5(2): 89-92. DOI: https:// doi.org/10.14318/hau5.2.006. 
Schultze, Kristen. 2004. 'The Free Aceh Movement (GAM): anatomy of a separatist organization.' Policy Studies No. 2. Washington, DC: East-West Center. Schultze, Kristen. 2007. 'GAM: Indonesia, GAM, and the Acehnese population in a zero-sum trap.' In Terror, insurgency, and the state: ending protracted conflicts, edited by Marianne Heiberg, Brendan O'Leary and John Tirman, 83-122. Philadelphia, PA: University of Pennsylvania Press.

Scott, James C. 2009. The art of not being governed: an anarchist history of upland Southeast Asia. New Haven, CT: Yale University Press.

Scott, Joan W. 2007. The politics of veil. Princeton, NJ: Princeton University Press.

Scott, Joan W. 2011. The fantasy of feminist history. Durham, NC: Duke University Press.

Sedgwick, Eve Kosofsky. 2003. Touching feeling: affect, pedagogy, performativity. London: Duke University Press.

Sehat AQUA. 2015. 'Kebaikan mengalir bagaikan air.' Accessed 14 November 2018. https://www.youtube.com/watch?v=BC5Biav6s90.

Selim, Samah. 2010. 'Politics of piety: the Islamic revival and the feminist subject.' Accessed 5 May 2016. http://www.jadaliyya.com/pages/index/235 /book-review_politics-of-piety_the-islamic-revival-.

Seppälä, Tiina. 2016. 'Feminizing resistance, decolonizing solidarity: contesting neoliberal development in the Global South.' Journal of Resistance Studies, 2(1): 12-47.

Serambi Indonesia. 2013. 'Gay rambah Banda Aceh.' Accessed 18 August 2020. https://aceh.tribunnews.com/2013/05/05/gay-rambah-banda-aceh.

Serambi Indonesia. 2016a. 'Film “Surga Menanti” diputar perdana di Jakarta.' Accessed 26 November 2019. https://aceh.tribunnews.com/2016/05/30/film -surga-menanti-diputar-perdana-di-jakarta.

Serambi Indonesia. 2016b. 'Film Surga Menanti tayang 2 Juni.' Accessed 14 November 2019. https://aceh.tribunnews.com/2016/05/28/film-surga-menanti -tayang-2-juni.

Serambi Indonesia. 2016c. 'Pemko harus serius tangani LGBT.' Accessed 19 February 2019. http://aceh.tribunnews.com/2016/02/13/pemko-harus -serius-tangani-lgbt.

Serambi Indonesia. 2016d. "VIDEO Illiza nyanyikan lagu "Nasihat Buda" di film Surga Menanti.' Accessed 14 November 2019. https://aceh.tribunnews .com/2016/05/30/video-iliza-nyanyikan-lagu-nasihat-bunda-di-film-surga -menanti.

Serambi Indonesia. 2017. 'Bustanussalatin, wajah baru taman sari Banda Aceh yang instagramable.' Accessed 26 November 2019. https://aceh.tribunnews .com/2017/01/24/bustanussalatin-wajah-baru-taman-sari-banda-aceh -yang-instagramable.

Serambi Indonesia. 2019a. 'Antara karier dan keluarga.' Accessed 15 November 2019. https://aceh.tribunnews.com/2019/05/12/antara-karier-dan-keluarga. 
Serambi Indonesia. 2019b. 'Mata Ie harus dipulihkan, ahli gua Aceh tawarkan sejumlah solusi.' Accessed 30 October 2019. https://aceh.tribunnews .com/2019/07/27/mata-ie-harus-dipulihkan-ahli-gua-aceh-tawarkan -sejumlah-solusi?page $=$ all.

Serambi Indonesia. 2019c. 'Perindag Aceh data industri air mineral untuk mengetahui kualitas produk.' Accessed 30 October 2019. https://aceh.tribunnews .com/2019/02/12/perindag-aceh-data-industri-air-mineral.

Setiadi, Hilmar Farid. 2014. 'Rewriting the nation: Pramoyedia and the politics of decolonization.' PhD thesis, Cultural Studies in Asia Program, National University of Singapore.

Shadiqin, Sehat Ihsan. 2009. Tasawuf Aceh. Banda Aceh: Bandar Publishing.

Shapiro, Michael J. 2013. Studies in Trans-Disciplinary Method: After the Aesthetic Turn. Oxon: Routledge.

Shilliam, Robbie. 2015. The black Pacific: anticolonial struggles and oceanic connections. London: Bloomsbury Academic Press.

Siapno, Jacqueline Aquino. 2002. Gender, Islam, nationalism and the state in Aceh: the paradox of power, co-optation and resistance. London: Routledge Curzon.

Sidaway, J. D. 2000. 'Postcolonial geographies: an exploratory essay.' Progress in Human Geography, 24(4): 591-612. https://doi.org/10.1191/030913200 100189120

Siegel, James T. 2000 [1969]. The rope of God. Ann Arbor, MI: University of Michigan Press.

Sindre, Gyda Marås. 2014. 'Rebels and aid in the context of peacebuilding and humanitarian disaster: a comparison of the Free Aceh Movement (GAM) and the Tamil Tigers (LTTE).' Forum for Development Studies, 41(1): 1-21. DOI: https://doi.org/10.1080/08039410.2013.832704.

Singerman, Diane. 2007. The economic imperatives of marriage: Emerging practices and identities among youth in Egypt. Middle East Youth Initiative Paper 6/2007. Wolfensohn Center for Development \& Dubai School of Government.

Siswayasa, Engking. 1984. Plastik masuk desa: studi tentang proses penyebaran produk-produk industri di pedesaan. Banda Aceh: Pusat Latihan Penelitian Ilmu-Ilmu Sosial.

Sjoberg, Laura. 2014. 'Queering the "territorial peace”? Queer theory conversing with mainstream international relations.' International Studies Review, 16(4): 608-612. DOI: https://doi.org/10.1111/misr.12186.

Skeggs, Beverley. 1997. Formation of class \& gender: becoming respectable. London: SAGE.

Skeggs, Beverley. 1999. 'Matter out of place: visibility and sexualities in leisure spaces.' Leisure Studies, 18(3): 213-232. DOI: https://doi.org/10.1080 /026143699374934.

Skeggs, Beverley and Helen Wood. 2012. Reacting to reality television: performance, audience and value. London: Routledge. 
Smith, Catherine. 2017. Resilience and the localisation of trauma in Aceh, Indonesia. Singapore: NUS Press.

Smith, Sara. 2012. 'Intimate Geopolitics: Religion, Marriage, and Reproductive Bodies in Leh, Ladakh.' Annals of the Association of American Geographers, 102(6): 1511-28. DOI: https://doi.org/10.1080/00045608.2012.660391

Song, Jaemin, Mooyoung Han, Tschung-il Kim and Jee-eun Song. 2009. 'Rainwater harvesting as a sustainable water supply option in Banda Aceh.' Desalination, 248(1): 233-240. DOI: https://doi.org/10.1016/j.desal.2008.05.060.

Spivak, Gayatri Chakravorty. 1988. 'Can subaltern speak?' In Marxism and the interpretation of culture, edited by Cary Nelson and Lawrence Grossberg, 271-313. Urbana IL: University of Illinois Press.

Spivak, Gayatri Chakravorty. 2008. Other Asias. Oxford: Blackwell Publishing. Srimulyani, Eka. 2010. 'Islam, adat, and the state: matrifocality in Aceh revisited.' Al-Jamiah, 48(2): 321-342. DOI: https://doi.org/10.14421/ajis.2010.482.

Srimulyani, Eka. 2012. Women from traditional Islamic educational institutions in Indonesia: negotiating public spaces. IIAS Publication Series, Monographs 8. Amsterdam: Amsterdam University Press.

Srimulyani, Eka. 2014. 'Gender in contemporary Acehnese dayah: moving beyond docile agency?' In Gender and power in Indonesian Islam: Leaders, feminists, Sufis and pesantren selves, edited by Bianca J. Smith and Mark Woodward, 66-80. London: Routledge.

Srimulyani, Eka. 2015. 'Teungku inong dayah: female religous leaders in contemporary Aceh.' In Islam and the limits of the state: reconfigurations of practice, community and authority in contemporary Aceh, edited by Michael Feener, David Kloos and Annemarie Samuels, 141-165. Leiden: Brill.

Srimulyani, Eka. 2017. 'Uncovering the sub-alternity: the peace process in women's perspectives, narratives, and agencies. In KACP collaborative research report: gender justice and democracy in Asia. Seoul: Asian Association of Women's Studies.

Srimulayani, Eka, Marjaana Jauhola, and Maida Irawani. 2018. 'Engendering Long-Term Recovery: Revisiting Women's Livelihood Support in Post -Tsunami Banda Aceh.' Unpublished manuscript.

Srinivas, Hari and Farhan Helmy. 2015. 'Disaster waste management: lessons learned from Banda Aceh, Indonesia.' In Recovery from the Indian Ocean tsunami, edited by Rajib Shaw. Tokyo: Springer.

Stange, Gunnar and Antje Missbach. 2011. 'A supreme ruler for Aceh?' 10 December. Accessed 30 May 2017. http://www.insideindonesia.org/a -supreme-ruler-for-aceh.

Stange, Gunnar and Roman Patock. 2010. 'From rebels to rulers and legislators: the political transformation of the Free Aceh Movement (GAM) in Indonesia.' Journal of Current Southeast Asian Affairs, 29(1): 95-120. https://doi .org/10.1177/186810341002900105.

Sultana, Farhana. 2018. 'Water justice: why it matters and how to achieve it.' Water International, 43(4): 483-493. 
Suoranta, Juho and Sanna Ryynänen. 2014. Taisteleva tutkimus. Helsinki: Into kustannus.

Suryakusuma, Julia I. 1996. 'The state and sexuality in New Order Indonesia.' In Fantasizing the feminine in Indonesia, edited by Laurie J. Sears, 92-119. London: Duke University Press.

Syam, Hamdani M. and Effendi Hasan. 2013. 'Perkembangan komunitas anak punk di kota Banda Aceh: pandangan masyarakat dan kebijakan pemerintah kota.' Jurnal Pendidikan Sains Sosial dan Kemanusiaan, 6(2): 159-168.

Syamsuddin, Otto. 2013. Aceh pasca konflik: kontestasi 3 varian nasionalisme. Banda Aceh: Bandar Publishing.

Sylvester, Christine. 2011. 'Eperiencing war: an introduction.' In Experiencing war, edited by Christine Sylvester. London and New York, NY: Routledge.

Sylvester, Christine. 2013. War as experience: contributions from international relations and feminist analysis. London: Routledge.

Taylor, Reed. 2015. 'Syariah as heterotopia: responses from Muslim women in Aceh, Indonesia.' Religions, 6(2): 566-593. DOI: https://doi.org/10.3390 /rel6020566.

Tempo.co. 2012. 'Rejecting a gay man running for a seat at Human Rights Commission.' 13 September. Accessed 13 December 2019. http://en.tempo.co /read/429352/rejecting-a-gay-man-running-for-a-seat-at-human-rights -commission.

Thajib, Ferdiansyiah M. A. 2014. 'Navigating inner conflict - online circulation of Indonesian Muslim queer emotions.' In Feelings at the margins: dealing with violence, stigma and isolation in Indonesia, edited by Thomas Stodulka and Birgitt Röttger-Rössler, 159-179. Frankfurt: Campus Verlag.

Thajib, Ferdiansyiah M. A. 2015. 'Living in a state of suspension: emotional dimensions of normative violence towards Indonesian queers in Islamic legal discourse.' Kyoto Review of Southeast Asia, 18. Accessed 20 July 2020. https://kyotoreview.org/issue-18/normative-violence-towards-indonesian -queers/.

Thajib, Ferdiyansyah M. A. 2017. 'Kaleidoscopic feelings: faith narratives amongst Indonesian Muslim queers.' Emotion, Space and Society, 25: 127-135. https://doi.org/10.1016/j.emospa.2016.11.007

Thajib, Ferdiansyiah M. A. 2018. 'The making and breaking of Indonesian Muslim queer safe spaces.' borderlands e-journal, 17(1): 1-24.

Tilche, Alice and Edward Simpson. 2017. 'On trusting ethnography: serendipity and the reflexive return to the fields of Gujarat'. Journal of the Royal Anthropological Institute, 23(4): 690-708. DOI: https://doi.org /10.1111/1467-9655.12695.

Törnquist, Olle. 2009. 'Introduction and general conclusions: Social Democratic peace: to be continued.' In Aceh: the role of democracy for peace and reconstruction, edited by Olle Törnquist, Stanley Adi Prasetyo and Teresa Birks, 1-54. Jakarta: ISAI. 
Törnquist, Olle. 2011. 'Dynamics of peace and democratization. The Aceh lessons.' Democratization, 18(3): 823-846. DOI: https://doi.org/10.1080/13 510347.2011.563118.

Tribunnews.com. 2013. "'arelemen Rusia dukung RUU larangan propaganda homoseksual.' Accessed 12 April 2018. http://www.tribunnews.com /internasional/2013/01/25/parlemen-rusia-dukung-ruu-larangan-propa ganda-homoseksual.

Trust Project. 2020. Accessed 17 June 2020. http://trust-project.eu/.

Tsai, Yen-Ling and Douglas Kammen. 2012. 'Anti-communist violence and the ethnic Chinese in Medan, North Sumatra.' In The contours of mass violence in Indonesia, 1965-68, edited by Douglas Kammen and Katharine McGregor, 131-155. Singapore: NUS Press.

Tsing, Anna Lowenhaupt. 2005. Friction: an ethnography of global connection. Oxford: Princeton University Press.

Tuck, Eve, and K. Wayne Yang. 2012. 'Decolonization Is Not a Metaphor.' Decolonization: Indigeneity, Education \& Society, 1(1): 1-40.

Tuhiwai Smith, Linda. 2008 [1999]. Decolonizing methodologies: research and indigenous peoples. London: Zed Books.

Uddin, Nasir. 2011. 'Decolonising ethnography in the field: an anthropological account.' International Journal of Social Research Methodology, 14(6): 455-467. DOI: https://doi.org/10.1080/13645579.2011.611382.

UN Human Rights Council. 2017. Matrice of recommendations: UPR of Indonesia 3rd Cycle -27th session. Accessed 26 November 2019. https://lib .ohchr.org/HRBodies/UPR/Documents/Session27/ID/MatriceRecommen dationsIndonesia.docx.

UN Population Fund, Women's Study Center IAIN Ar-Raniry and Oxfam. 2005. 'Gender and changes in tsunami-affected villages in Nanggroe Aceh Darussalam province.' Accessed 14 November 2018. https://oxfamilibrary.open repository.com/bitstream/handle/10546/112418/gender-changes-tsunami -affected-villages-nanggroe-aceh-darussalan-province-011205-en.pdf;jsess ionid=A64A7A334F3D34F91C7B6A430D400467? sequence $=1$.

Väätäinen, Hanna. 2003. Rumbasta rampaan: vammaisen naistanssijan ruumiillisuus pyörätuolikilpatanssissa. Åbo: Åbo Akademi University Press.

Väätäinen, Hanna. 2009. Liikkeessä pysymisen taika: etnografisia kokeiluja yhteisötanssiryhmässä. Turku: Eetos.

Vaittinen, Tiina, Amanda Donahoe, Rahel Kunz, Silja Bára Ómarsdóttir and Sanam Roohi. 2019. 'Care as everyday peacebuilding.' Peacebuilding, 7(2): 194-209. DOI: https://doi.org/10.1080/21647259.2019.1588453.

van Doorn-Harder, Pieternella. 2006. Women shaping Islam: reading the Quran in Indonesia. Urbana, IL: University of Illinois Press.

Vantaan taidemuseo ARTSI. n.d. 'PAX - puhutaan rauhasta.' Accessed 18 August 2020. http://www.artsimuseo.com/pax-puhutaan-rauhasta.

Vastapuu, Leena. 2018. Liberia's women veterans: war, roles and reintegration. London: Zed Books.

Väyrynen, Tarja. 2013. 'Keeping the trauma of war open in the male body: resisting the hegemonic forms of masculinity and national identity in visual 
arts.' Journal of Gender Studies, 22(2): 137-151. DOI: https://doi.org/10.10 80/09589236.2012.745686.

Vignato, Silvia. 2012. "Men come in, men go out": single Muslim women in Malaysia and Aceh.' Social Identities, 18(2): 239-257. DOI: https://doi.org /10.1080/13504630.2012.652847.

Vignato, Silvia. forthcoming. Motherly landscapes: Matrifocality, marriage, Islam and the change of generation in post conflict, post-tsunami Aceh. Rome: ISMEO.

Visweswaran, Kamala. 1994. Fictions of feminist ethnography. Minneapolis, MN: University of Minnesota Press.

Vitalis, Robert. 2015. White world order, black power politics: the birth of American international relations. Ithaca, NY: Cornell University Press.

Waizenegger, Arno and Jennifer Hyndman. 2011. 'Salient versus silent disasters in post-conflict Aceh, Indonesia.' In Reconstructing conflict: integrating war and post-war geographies, edited by Kirsch Scott and Colin Flint, 67-90. Farnham: Ashgate.

Wallach, Jeremy. 2008. 'Living the punk lifestyle in Jakarta.' Ethnomusicology, 52(1): 98-116. DOI: https://doi.org/10.2307/20174568.

Wandita, Galuh. 2014. 'PREMAN NATION: watching the act of killing in Indonesia.' Critical Asian Studies, 46(1): 167-170. DOI: https://doi.org/10 $.1080 / 14672715.2014 .863585$.

Wardani. 2010. 'Astrologi Dan Pengobatan Melayu Dalam Kitab Tâj Al-Muk.' Al-Banjari, 9(1): 87-115.

Waterson, Roxana. 2007. 'Introduction: analysing personal narratives.' In Southeast Asian lives: personal lives and historical experience, edited by Roxana Waterson, 1-40. Singapore: NUS Press.

Weber, Cynthia. 2014. 'From queer to queer IR.' International Studies Review, 16(4): 596-601. DOI: https://doi.org/10.1111/misr.12160.

Weber, Cynthia. 2016. Queer international relations: sovereignty, sexuality and the will to knowledge. Oxford: Oxford University Press.

West, Paige. 2016. Teaching Decolonizing Methodologies. Accessed 12 August 2020. https://savageminds.org/2016/07/25/teaching-decolonizing-meth odologies/

Wibben, Annick T. R. 2016. 'Introduction: feminists study war.' In Researching war: feminist, methods, ethics and politics, edited by Annick T. R. Wibben, 1-16. London: Routledge.

Wieringa, Saskia E. 1992. 'Ibu or the beast: gender interests in two Indonesian women's organisations.' Feminist Review, 41(1): 98-113. DOI: https://doi .org/10.1057/fr.1992.33.

Wieringa, Saskia E. 2002. Sexual politics in Indonesia. New York, NY: Palgrave Macmillan.

Wieringa, Saskia E. 2011. 'Portrait of a women's marriage: navigating between lesbophobia and Islamophobia.' Signs, 36(4): 785-793. DOI: https://doi .org/10.1086/658858.

Wikan, Unni. 1992. 'Beyond the words: the power of resonance.' American Ethnologist, 19(3): 460-482. DOI: https://doi.org/10.1525/ae.1992.19.3.02a00030. 
Wilcox, Lauren. 2014. 'Queer theory and the "proper objects" of international relations.' International Studies Review, 16(4): 612-615. DOI: https://doi .org/10.1111/misr.12187.

Willems, Joachim. 2014. 'Why 'punk'? Religion, anarchism and feminism in Pussy Riot's Punk Prayer.' Religion, State and Society, 42(4): 403-419. DOI: https://doi.org/10.1080/09637494.2014.988397.

Wilson, Ian. 2010. 'The rise and fall of political gangsters in Indonesian democracy'. In Problems of democratisation in Indonesia: elections, institutions and society, edited by Edward Aspinall and Marcus Mietzner, 199-218. Singapore: ISEAS Publishing.

Yatim, Debra H. 2005. Of Aceh and turning tides: songs for my sisters. Banda Aceh: Acehkita Foundation.

Zarkov, Dubravka. 2001. 'The body of the other man: sexual violence and the construction of masculinity, sexuality and ethnicity in the Croatian media.' In Victims, perpetrators or actors? Gender, armed conflict and political violence, edited by Caroline O. N. Moser and Fiona C. Clark, 69-82. New Delhi: Kali for Women.

Zarkov, Dubravka. 2008. 'Foreword: gender, violent conflict and development: challenges of practice.' In Gender, conflict, development: challenges of practice, edited by Dubravka Zarkov, xi-xix. New Delhi: Zubaan.

Zuhri, Saifuddin. 2006. 'Dalaq di pesantren.' Masters thesis, Center for Religious and Cross-Cultural Studies, Gadjah Mada University. 


\section{A Note on the Sources of the Chapters}

Parts of chapters and/or their earlier versions have been published in:

Jauhola, Marjaana. 2015. 'On "being bored" - street ethnography on emotions in Banda Aceh after the tsunami and conflict.' In Emotions, politics and war, edited by Linda Åhäll and Thomas Gregory, 86-99. London: Routledge. (Sections used in Chapter 1.)

Jauhola, Marjaana. 2015. 'Scraps of home: social and vernacular memory and politics of disaster humanitarianism in Aceh, Indonesia.' Asian Journal of Social Science, 43(6): 738-759. (Sections used in Chapter 3.)

Jauhola, Marjaana. 2017. 'A.C.A.B. - studying up the rule of law in Banda Aceh, Indonesia.' Punk \& Post Punk, 6(2): 213-232. (Sections used in Chapter 5.)

Jauhola, Marjaana. 2017. 'Visual ethnographic encounters and silence in postconflict city of Banda Aceh, Indonesia.' In Experiences with violent research and researching violence, edited by Althea-Maria Rivas and Brendan Browne, 179-184. Bristol: Polity Press. (Sections used in Chapter 4.) 



\section{Index}

A

'A.C.A.B' (punk song) 153

Abbas, Syahrizal 41, 52

Abdillah, Ustazah Rifqiyya 183

Abdulah, Sait 7, 48, 108

Abdullah, Zaini 54

Aceh - the Black Road (film) 123

Aceh calling (punk song collection) 144

'Aceh calling' punk gig 152

Aceh Commission for

Disappearances and Victims of Violence in Aceh (Kontras Aceh) 218

Aceh TV election debate 56

Aceh Women's Peace Foundation (AWPF) 147

Acehnese Muslim Students

Association (KAMMI) 169

adultery laws 50

Afary, Janet 26, 28
Agathangelou, Anna M. 114

agency 23, 27

Ahmed, Sara 30, 35

Ahtisaari, Martti 9, 51, 52

Al-Habsyi, Habib Idrus 60

al-haya 22

amar máruf nahi mungkar 60,180

Anderson, Kevin B. 26, 28

anti-LGBTI campaigns 78 , 169, 180

anti-pornography bill 50

ASEAN 84,170

Aspinall, Edward 111

Awaludin, Hamid 9

Aziza (research participant) 90

B

Babe (research participant) 173

Balai Syuara 82

Bali, Maha 31

Baltzar, Carmen 218 


Banda Aceh 8
ethnographic data collection 32
gender-friendly city campaign 72
impacts of tsunami 8
metal music community 156
Paradise Awaits (film) 66
tsunami sites tours 9
see also bottled water; kota madani
(civilised city); post-conflict
masculinities; punk
community; queer community
and care; research process;
women's lived experiences.
Bangstad, Sindre 25
bapak masculinity 108, 137

'Bastard Illiza' (punk song) 130, 134

being exposed, as research method 34

Bertrand, Sarah 8, 19

Biehl, João 31, 34

Boellstorff, Tom 165, 168-169

Botoel Kosoenk (punk band) 129

bottled water 193

advertisements 193, 200

bottle recycling centres 201

history and context 197

middle classes and 193,211-212

recycling in economics of urban poor 210

Bowen, John 112

BPPPA (Office for the Empowerment of Women and Protection of Children) 74

Bracke, Sarah 88-89

Braithwaite, John 3

'Bunda's Advice' (song and video) 67

Bunny (punk) see Rex incident.

Bustannusalatin Park, Banda Aceh 47

Butler, Judith 23
C

Cairoean piety movement

$23,27-28$

caning punishments 49-50

Casas-Cortés, Mariá Isabel 30

Catholic Relief Services (CRS) 46

ChaCha (research participant) 100

Chakrabarty, Dipesh 28, 202

'Changing dimensions' (metal song) 157

'Cheap film' (punk song) 133, 138

church attacks 61,101

civilised Islamic city

see kota madani (civilised city).

Clark, Marshall 71

co-creation of research 30

Connell, Raewyn 29

Convention on the Elimination of all Forms of Discrimination

Against Women

(CEDAW) 52, 78

cooking competition 73

corporal punishment 49-50

Cronic (metal band) 156

Cut Nyek Dhien 79

D

D'Costa, Bina 3, 221

da'wa movement

da'wa lectures 60

Egyptian 23, 27-28

guidance towards ideal womanhood 67

legal framework 48

role of Mayor Illiza 56,61,67

waste management and 202

Women and Shariah campaign 76,82

see also women's lived experiences.

Daud, Darni M. 154

decolonial feminist solidarity 30 
decolonialised research methods $28 \quad$ G see also research process.

Dedi (research participant)

di Tiro, Hasan 82

'Difference is not a war' (punk song) 159

Djohar, Zubaidah $7,39,43,87,89$, $118,194,217$

documentary film production research process 36 subaltern practice 31 see also research videos.

Douglas, Mary 202

drinking water see bottled water.

Drwiega, Yuyun Ismawati 200

E

Egyptian piety movement 23 , 27-28

ethnographic refusal 25

ex-combatants see post-conflict masculinities.

F

Family Welfare Programme (PKK) 73, 212

Feener, Michael 133

Field, Syd 38

FORKAB (Forum Komunikasi Anak Bangsa) 108

Foucault and the Iranian Revolution Gender and the Seductions of Islamism (Afary and Anderson) 26, 28

Foucault, Michel 23, 26-27

Free Aceh Movement $8-9,48-49$, 54,82 see also post-conflict masculinities. Front Pembela Islam (FPI) 60, 72, 169

GAM

see Free Aceh Movement.

gangsterism (premanisme) 122

gay archipelago metaphor 165

Gay Homeland Foundation 163

Gender Working Group network 113

gendered piety

da'wa lectures 60

Egyptian piety movement 23 , $27-28$

guidance towards ideal womanhood 67

legal framework 48

role of Mayor Illiza 56, 61, 67 waste management and 202

Women and Shariah campaign 76,82

see also women's lived experiences. gender-friendly city campaign 72 Grosz, Elizabeth 34

\section{H}

Habitat II Conference 72

Hadiz, Vedi 47

Hajj event 75

Hall, Stuart 18

Harding, Sandra 29

Hawkins, G. 196, 200, 202, 203, 211

healing, traditional $109,121,124$

Helmy, Farhan 203

Helsinki Peace Process 6, 49, 51 see also post-conflict masculinities. here-and-now ethnographical method 21, 28, 32

hermeneutics of suspicion 22

Hirstiö, Seija 37

HIV/AIDS 182

Hizbut Tahrir Indonesia (HTI) 72, $76,82,139,169,182$ 
Hoesterey, James B. and Clark 71 homosexuality see queer community and care.

Hongisto, Ilona 39

Human Rights Commission of Indonesia 169

Hurgronje, Snouck 111

I

ideal womanhood

see gendered piety.

Illiza Saaduddin Djamal 56, 61, 67, 130,180

Indah (research participant) 98

Indonesian Criminal Code

Procedure (KUHAP) 150

Inhorn, Marcia C. 113

Institute for Criminal Justice Review (ICJR) 51

International Day Against

Homophobia

(IDAHO) 174

International Human Rights

Day 218

International Studies

Association 165

International Women's Day (IWD)

celebration 76,82

Iranian Revolution 26, 28

Iskandar Muda, Sultan of Aceh 110,124

Islamic Criminal Law (Qanun Jinayat) $49,169,187$

Islamic Defenders Front (FPI) 60, 72,169

Islamic dress 49

Islamic piety and morality

da'wa lectures 60

Egyptian piety movement 23 , $27-28$

guidance towards ideal womanhood 67

legal framework 48

role of Mayor Illiza 56, 61, 67 waste management and 202 see also women's lived experiences.

Women and Shariah campaign 76,82

Islamic populism

see kota madani (civilised city). istilah 23

J

Japan International Cooperation Agency 197

Jayasankar, K. P. 31

K

kakak-adik couples 174

Kalla, Yusuf 169

Kandiyoti, Deniz 5

Kartini, R. A. 200

khalwat laws 50, 54, 173, 187

khanna, akshay 163

Khatami, Mahmoud 27

Kim, Jim Yong 170

Kitab Mujarabat 124

Kloos, David 60

kodrat 49, 175

Kontras Aceh (Aceh Commission for Disappearances and Victims of Violence in Aceh) 218

kota madani (civilised city) 45

amar ma'ruf nahi mungkar

60,180

conceptualisation of vision of 55

governance of gender and sexual politics 48

guidance towards ideal womanhood 67

International Women's Day (IWD) celebration 76,82

Paradise Awaits (film) 66

public sphere contestation 76

role of Mayor Illiza 56, 61, 67

Women and Shariah campaign 76,82

'Kundalini' (metal song) 159 
L

La Rêverie - woman in a 18th century dress (Löfgren) 10

Laksamana Hayati 79

Lambek, Michael 36

Law on Governance of Aceh

(LOGA) 6, 48

law, Sharia

see Sharia law.

Lee-Koo, Katrina 7

lesbianism 171

accusations to silence women activists 51

criminalisation of lesbian acts 49-50

lived experiences of tombois 166,173

see also queer community and care.

LeVine, Mark 5, 23

LGBTI community

see queer community and care.

life-historical video production 36 see also research videos, research process.

Locke, Peter 31, 34

Löfgren, Erik Johan 10

Lorde, Audre 176

Lugones, Maria 30

\section{M}

madani 56,71 see also kota madani (civilised city).

'Mahakebo' (punk song) 154

Mahmood, Saba 23, 27-28

Mahmud, Malik 9

Manaf, Muzakir 108

Mariyani (research participant) 93

Marjinal (punk band) 135, 147,154

marriage, unregistered $\quad 40,54,93$

'Marsinah' (punk song) 135

masculinities

see post-conflict masculinities.

Mata Ie 214 matrifocal village customs

$$
\text { 111-112 }
$$

Mawardi Nurdin 56, 61

McCall, Corey 26

Mead, Margaret $\quad 40,168$

Medina 56, 71

Memorandum of Understanding 6 , 49,51

see also post-conflict masculinities.

Mercy Corps 46

Meszaros, Istvan 196

metal music community 156

Mila (research participant) $\quad 45,220$

mindful research practice 21 , 28,32

Mohanty, Chandra 3, 89, 219

Monteiro, Anjali 31

$\mathrm{MoU}$

see Memorandum of Understanding.

MPU (Ulama Consultative Assembly) 50

Muhammad (punk) see Rex incident.

muhtasibs 60

multiple modernities 26

multi-sited ethnography 32

Murrell, Peter 167

muslihat 22

'My Aceh, do not cry'

(punk song) 133

'My Land' (punk song) 152

$\mathbf{N}$

Nasution, Abdillah Imron 214

Nawaz, Nazreen $\quad 82,83$

Nelson, William 123

new materialist documentarism 37

New Order period $\quad 51,60,77,168$

Niemi, Jenni-Justiina 9

nikah siri 40, 54, 93

Nizar, Muhammad 200

Noble, Denise 4

Nurdin, Muhammad Reza $\quad 78,80$ 
O

Oetomo, Dede 169, 174

Office for the Empowerment of Women and Protection of Children (BPPPA) 74

Ong, Aihwa 5

Ortner, Sherry 26

Osterweil, Michal 30

'Our wounds' (punk song) 135

$\mathbf{P}$

Pabón-Colón, Jessica Nydia 134

Pacheco-Vega, Raul 195

Page, Tiffany 30

Pandjaitan, Luhut 170

Paradise Awaits (film) 66

paranoid paradigm 22

'PAX - Let's Speak of Peace' (exhibition) 42

peace process $\quad 6,49,51$

see also post-conflict masculinities.

Persatuan Persaudaraan Pedagang Aceh (P3A) 123

PET bottles

see bottled water.

phenomenology of whiteness 35

piety movement

see Islamic piety and morality.

Pink, Sarah 31

PKK (Family Welfare

$$
\text { Programme) 73, } 212
$$

PKS (Prosperous Justice Party)

$$
\text { 93, } 176
$$

Po (punk)

see Rex incident.

political spirituality 27

Politics of Piety (Mahmood) 23, $27-28$

polygamy $40,54,93$

populist politics

see kota madani (civilised city).

postcolonial critique of academic knowledge praxis 17 reversed research methods 28

subjectivity, agency and

freedom 20

post-conflict masculinities 107

bapak masculinity 108,137

healing praxis of Sufi healer 124

journey from ex-combatant to Sufi healer 114

many faces of 107

premanisme/gangsterism 122

punk community and 137, 139

poststructuralist feminism 23

Powell, Dana E. 30

Prasetiawan, Teddy 196

premanisme (gangsterism) 122

'Prison of thoughts' (punk song) 151

punishments $49-50$

Punk Aid 144, 146

punk community 130

'Aceh calling' gig 152

arrests and re-education 130

masculinities and 137, 139

Rex incident 139

rhizomatic homes 138

tsunami trauma and 135

punk songs

'A.C.A.B' 153

'Bastard Illiza 130, 134

'Cheap film' 133, 138

'Difference is not a war' 159

'Mahakebo' 154

'Marsinah' 135

'My Aceh, do not cry' 133

'My Land' 152

'Our wounds' 135

'Prison of thoughts' 151

Putri (research participant) 103

Puumala, Eeva 34

Q

Qanun Hukum Keluarga (Law on Family) 55 
Qanun Jinayat (Islamic Criminal

$$
\text { Law) } 49
$$

queer community and care 161

Acehnese queer poetry 176

anti-LGBTI campaigns 78,

169,180

Coaching to be strong transman video $40,161,164,184$

colonial histories of 167

criminalisation of same-sex acts $\quad 49-50,52,54,169$

human rights organisations and 189

Islamic Criminal Law and 49-50, $52,54,169,187$

LGBTI activism $\quad 165,169,171$

lived experiences of tombois and transmen 166, 173

politicisation of gender and sexuality 169

theory and methodology 162 virtual safety 187

\section{$\mathbf{R}$}

Raheja, Michelle 42

Rahimi, Babak 26, 28

Raiz (research participant) 161, 184, 188-189

Rao, Rahul 2, 4, 25, 163, 164

reality TV programmes 38

reconstruction of subjecthood

$$
19,37
$$

recycling 199

bottle recycling centres 201

in economics of urban poor 210

reflexivity 30

Relawan Perempuan untuk

Kemanusiaan (RPuK) 43

Religious Harmony Forums 66

reparative reading 22

research process 32,218

documentary film production

here-and-now ethnographical method 21, 28, 32

multi-sited ethnography 32 research videos

A good mother 100

Coaching to be strong transman $40,161,164,184$

Don't be angry 194, 205

Dreamcatcher 46

From ex-combatant to Sufi healer 1-3 114

MoU Helsinki reclaiming back history $11,41,85$

Poetic resistance I: whose peace is this? 7

Poetic resistance II: because you are a woman 89

Sharia and visions for peace blueprint for just and equal Islamic law 41, 52

Smile that hides sorrow 90

Solving nikah siri - unregistered marriage $40,54,93$

Totaliter penjara pemikiran/prison of thoughts 151

researching back 29

reversed research methods 28

see also research process.

Rex incident 139

Richter-Montpetit, Melanie 163

ROMI \& The JAHATs (punk band) 138

Rothstein, Michael 144, 146

RPJMD development plan 56

S

Sabaratnam, Meera 3, 19, 25, 37

sabr 22

Salvatore, Armando 5, 23

same-sex acts

colonial histories of 167

criminalisation of $49-50,52$, 54, 169

Schenk, Christine 47, 49, 55

Schouten, Joost 168

secretive marriage

see unregistered marriage.

Sedgwick, Eve Kosofsky 22, 222 
self-reflexivity 30

Seppälä, Tiina 30

Septiono, Mochamad Adi 200

Serambi Indonesia 47,70-71, 73, $131,139,141,182,214$

Setiadi, Hilmar Farid ～4, 219

Shari'a court 54

Shari'a law 8,48

arrests and re-education of punks 130

criminalisation of same-sex acts $\quad 49-50,52,54,169$

Islamic Criminal Law (Qanun Jinayat) $\quad 49,169,187$

khalwat laws $50,54,173,187$

Law on Family (Qanun Hukum Keluarga) 55

punishments 49-50

Shari'a and visions for peace blueprint for just and equal Islamic law (video) 41, 52

TAMAR (Tim Amar Makruf) teams 60

Women and Shariah campaign 76,82

zina laws 50

Shari'a Police $49,60,66$, $172,173,187$

silencing 19

Simpson, Edward 30

Siswayasa, Engking 199

Skeggs, Beverley 19, 37, 89

Smith, Sara 55

social media 37,41

anti-LGBTI campaigns 181-182

'Bunda's Advice' (song and video) 67

International Women's Day (IWD) celebration 76,82

queer community and 171,187

Rex incident research 140,143 , 147, 156

use by Mayor Illiza and elite women $70,71,75,181$
Women and Shariah campaign 76,82

Solidaritas Perempuan (Women's Solidarity for Human Rights) $\quad 11,41,51,76,82,84$

Spies, Walter 168

Spivak, Gayatri Chakravorty 17, 19, 29,134

Srimulyani, Eka 2, 10, 41

Srinivas, Hari 203

State Ibuism 49

stoning to death 50

Studio 77 157, 159

stumbling scholarship 218

see also research process.

subjecthood, reconstruction of 19,37

subjectivity 20

Sufi healer (research participant) 107, 109, 114, $124,210,221$

Sufism 109, 121, 124

Sugesty, Mifta 39

Suharto $49,60,77,137,168$

Sultana, Farhana 195

Supreme Court of Indonesia 184

Surga Menanti (film) 66

Susi (research participant) 61

Susianti, Evi 39

Swita, Donna 10,41

\section{$\mathbf{T}$}

Taj ul-Alam Safiatuddin Syah, Sultanah of Aceh $\quad 110,168$

Taman Sari park, Banda Aceh 45-46, 198

TAMAR (Tim Amar Makruf) teams 60

'Tempest of Tanoh Rencong' (poem) 80

Thajib, Ferdiansyiah M. A. 169

Tilche, Alice 30

Toer, Pramoyedia 4 


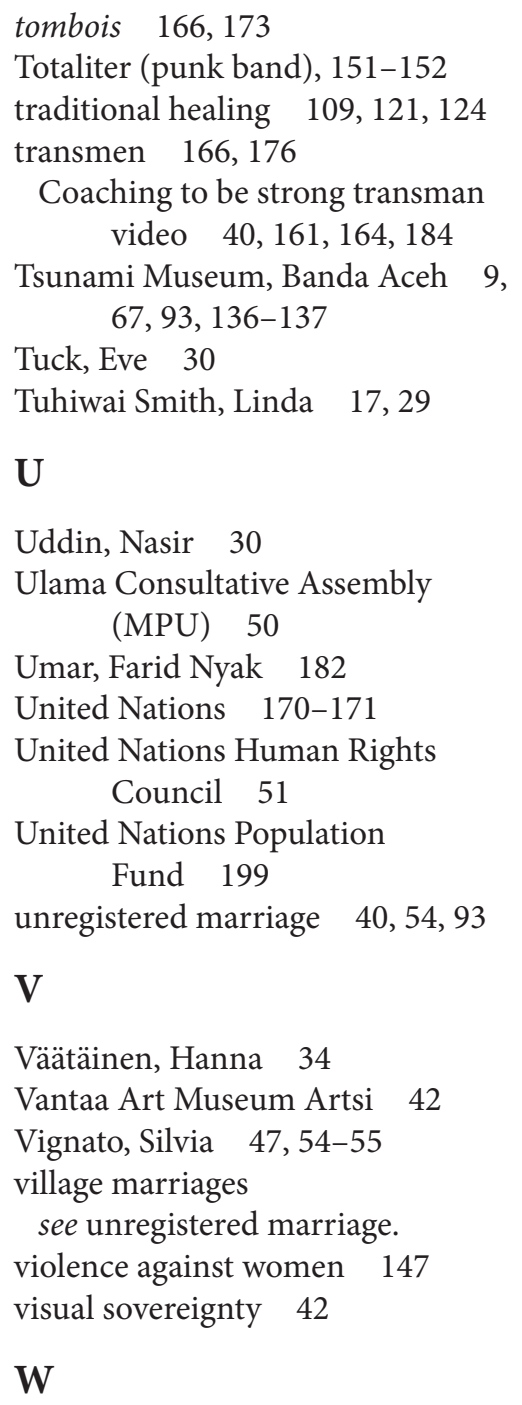

water

see bottled water.

white gaze $38,40-41$

white saviourism 41, 90

whiteness, phenomenology of 35

Wieringa, Saskia 50

Wilayatul Hisbah (Sharia

Police) 49, 60, 66, 172, 173

Women and Shariah campaign

$$
76,82
$$

women's lived experiences 87

Aziza 90

ChaCha 100

Indah 98

Mariyani 93

Mila 45, 220

Putri 103

Susi 61

Women's Solidarity for Human

Rights 11, 41, 51, 76,

82,84

Wood, Helen 37

World Bank Group 170

\section{Y}

Yang, Wayne K. 30

Yatim, Debra H. 1, 5

Yudi Bolong (punk) see Rex incident.

\section{Z}

zina accusations, to silence women activists 51

zina laws 50 
craps of Hope in Banda Aceh examines the rebuilding of the city of Banda Aceh in Indonesia in the aftermath of the celebrated Helsinki-based peace mediation process, thirty years of armed conflict, and the tsunami. Offering a critical contribution to the study of post-conflict politics, the book includes 14 documentary videos reflecting individuals' experiences on rebuilding the city and following the everyday lives of people in Banda Aceh.

Marjaana Jauhola mirrors the peace-making process from the perspective of the 'outcast' and invisible, challenging the selective narrative and ideals of the peace as a success story. Jauhola provides alternative ways to reflect the peace dialogue using ethnographic and film documentarist storytelling.

Scraps of Hope in Banda Aceh tells a story of layered exiles and displacement, revealing hidden narratives of violence and grief while exposing struggles over gendered expectations of being good and respectable women and men. It brings to light the multiple ways of arranging lives and forming caring relationships outside the normative notions of nuclear family and home, and offers insights into the relations of power and violence that are embedded in the peace.

Marjaana Jauhola is senior lecturer and head of discipline of Global Development Studies at the University of Helsinki. Her research focuses on co-creative research methodologies, urban and visual ethnography with an eye on feminisms, as well as global politics of conflict and disaster recovery in South and Southeast Asia.

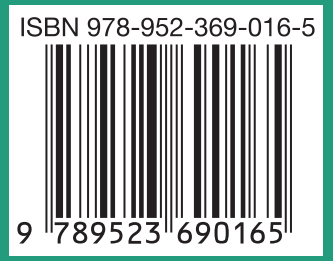

